\title{
DISPOSIÇÃO DE RESÍDUOS GERADOS EM ESTAÇÕES DE TRATAMENTO DE ÁGUA EM ESTAÇÕES DE TRATAMENTO DE ESGOTO
}

PAULO SERGIO SCALIZE

Tese apresentada à Escola de Engenharia de São Carlos, da Universidade de São Paulo, como parte dos requisitos para obtenção do título de Doutor em Hidráulica e Saneamento.

ORIENTADOR: Prof. Dr. Luiz Di Bernardo

São Carlos

2003 
Fic ha cata lográfica preparada pela Seção de Tratamento da Informação do Serviço de Biblioteca - EESC/USP

Scalize, Paulo Sérgio

Disposição de resíduos gerados em estações de tratamento de água em estações de tratamento de

esgoto / Paulo Sérgio Scalize. -- São Carlos, 2003.

Tese (Doutorado) -- Escola de Engenharia de São Carlos-Universidade de São Paulo, 2003.

Área : Hidráulica e Saneamento.

Orientador: Prof. Dr. Luiz Di Bernardo.

1. Resíduos de ETA. 2. Tratabilidade de lodos.

3. Lodo de ETA. 4. Lodo de ETE. I. Título. 


\section{FOLHA DE JULGAMENTO}

Candidato: Bacharel PAULO SERGIO SCALIZE

Tese defendida e julgada em 08-08-2003 perante a Comissão Julgadora:

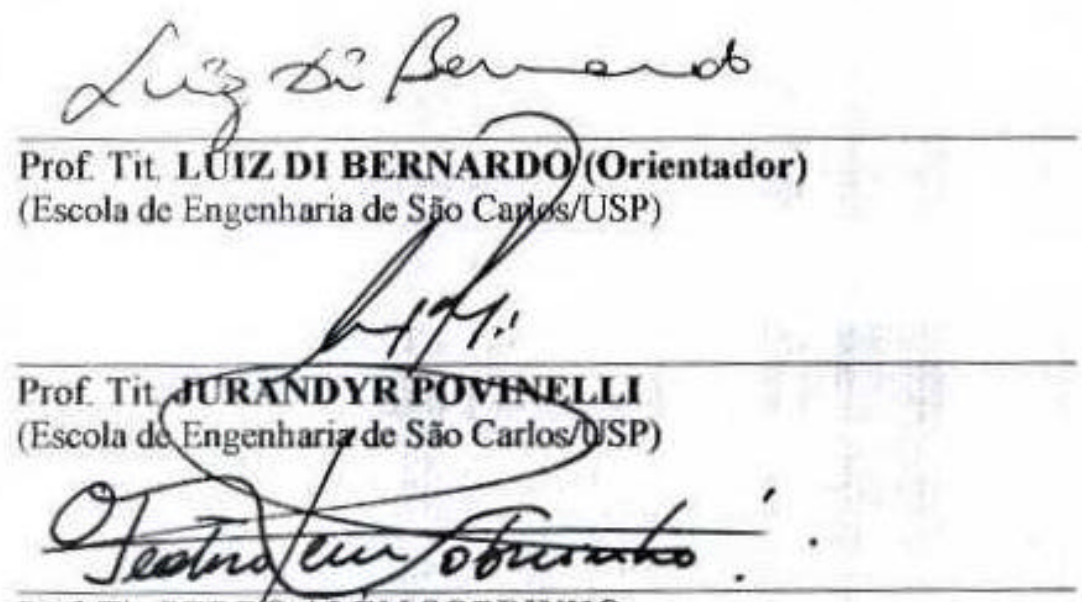

ARROUAOS

Prof Tit, LUIZ DI BERNARDO(Orientador)

(Escola de Engenharia de Sjo Caples/USP)

Prof Tit. PEDRO ALEM SOBRINHO

(Escola Politécnica/USP)

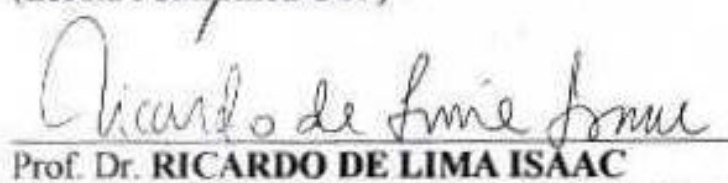

(Universidade Estadual de Campinas/UNICAMP)

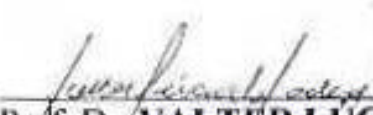

Próf Dr/VALTER LUCIO DE PÁDUA

(Universidade Federal de Minas Gerais/UFMG)

\section{AProditio}

\section{P120V480}

APROVADO

) 
Aos meus pais,

meus primeiros e grandes professores.

Aos meus irmãos, Marcos Antonio Scalize e Fábio Eduardo Scalize.

A Adriana, minha esposa e companheira.

Ao meu filho Vinícius, minha melhor experiência. 


\section{AGRADECIMENTOS}

Ao Professor Dr. Luiz Di Bernardo, pela sua dedicação, incentivo e excelente orientação fornecida para a conclusão deste trabalho.

A todos professores do Departamento de Hidráulica e Saneamento da EESC/USP.

Ao Conselho Nacional de Pesquisa Tecnológica e Científica - CNPq, pela bolsa de estudo concedida.

Aos amigos Paulo, Júlio e Cidinha técnicos do laboratório de Saneamento do SHSEESC/USP, pela dedicação no auxílio de todo trabalho prático.

Ás técnicas do Laboratório de Anaeróbios da EESC/USP, Eloísa, Janja, Beth e Ana Paula pela ajuda durante a parte experimental.

A Sá, Pavi, Cecília, Valderez, Márcia, Flávia e Rose da secretaria do SHSEESC/USP pelo auxílio durante toda permanência neste departamento.

Ao Técnico e amigo Francisco Carlos Bergamin pelo auxílio na montagem dos equipamentos necessários ao desenvolvimento da pesquisa.

Ao Sr. Luís Barbosa Campos Jr. do SAAE-SC que permitiu as coletas de material na ETA-SC, e aos Operadores de Tratamento que auxiliaram nas coletas.

Ao amigo Prof. Dr. Antônio Sérgio Spanó Seixas do Departamento de Ciências da Saúde da Universidade Federal de São Carlos.

À Profa. Dra. Maria Olímpia de Oliveira Rezende e a Dra. Maria Diva Landgraf do grupo de Química Ambiental - USP - São Carlos, pela realização das análises de pesticidas.

Ao Superintendente do DAAE de Araraquara Dr. Wellington Cyro de Almeida Leite e ao Gerente de Produção Eng ${ }^{\circ}$ Daniel Augusto Roma pela autorização e disponibilidade de recursos para montagem da Estação Piloto na ETE-Araraquara.

A Michele, Renata, Sérgio, Simone, Sônia, Wagner, Isac, José Maurílio e Manuel amigos e funcionários do DAAE-Araraquara que tiveram papel fundamental na conclusão deste trabalho.

Aos inúmeros amigos que conquistei em São Carlos e as pessoas que de forma indireta colaboraram com o trabalho. 


\section{SUMÁRIO}

LISTA DE FIGURAS ..............................................................................................

LISTA DE TABELAS …......................................................................................

LISTA DE ABREVIATURAS E SIGLAS ..............................................................II

LISTA DE SÍMBOLOS................................................................................. XIV

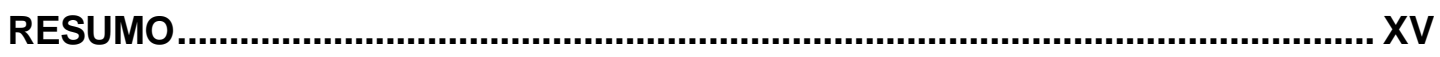

ABSTRACT

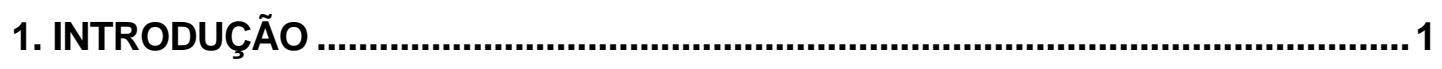

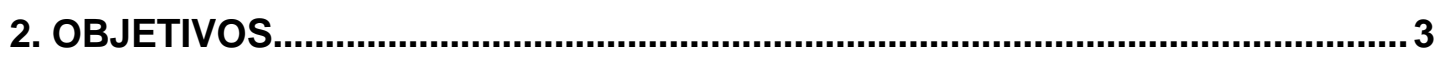

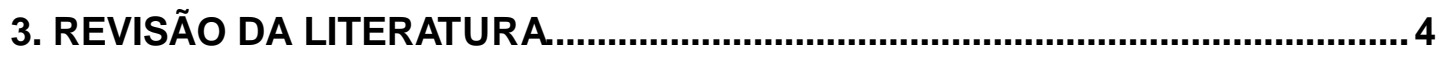

3.1. CONCEITO DOS RESÍDUOS GERADOS NAS ETAS ..................................... 4

3.1.1. Origem dos Resíduos Gerados em ETAs ............................................. 4

3.1.1.1. Limpeza dos Decantadores ........................................................ 4

3.1.1.2. Lavagem dos Filtros .................................................................. 5

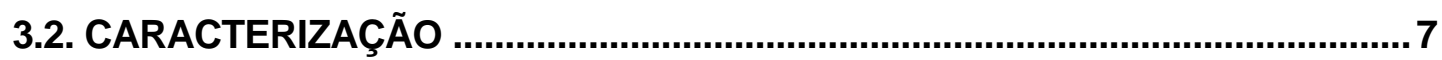

3.2.1. Caracterís ticas Físicas ......................................................................

3.2.1.1. Tamanho e Distribuição de Partículas ................................................ 11

3.2.1.2. Sedimentabilidade ..................................................................... 12

3.2.1.3. Resistência Específica à Filtração...................................................... 14

3.2.2. Características Biológicas ....................................................................... 17

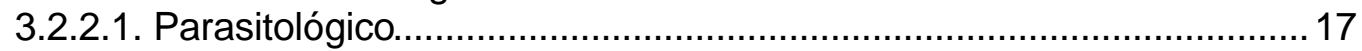

3.2.2.1.1. Ovos e Larvas de Helmintos .................................................. 18

3.2.2.2. Coliformes Totais e Escherichia coli.................................................. 19

3.2.3. Características Químicas.................................................................... 20

3.2.3.1. Metais Pesados ................................................................................. 20

3.3. MÉTODOS DE TRATAMENTO E DISPOSIÇÃO DOS RESÍDUOS....................22

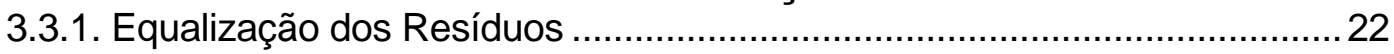

3.3.2. Condicionamento e Adensamento dos Resíduos .....................................2 24

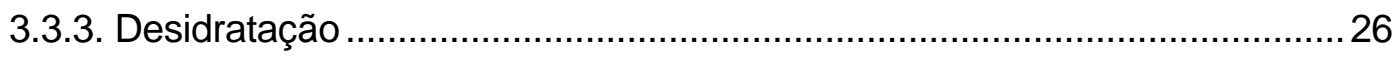

3.3.3.1. Desidratação Natural .................................................................... 26

3.3.3.2. Desidratação Mecânica ................................................................. 27

3.3.3.2.1. Desidratação por Centrifugação de Lodo de ETA e ETE ..............27 


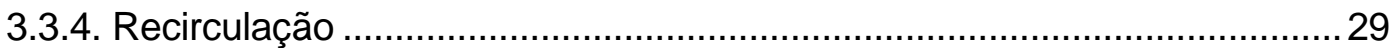

3.3.4.1. Recirculação Total do Resíduo ..................................................... 30

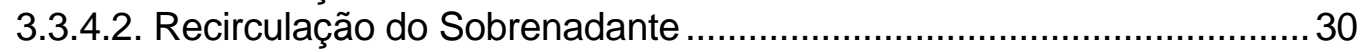

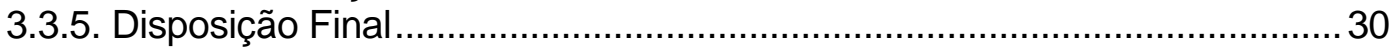

3.3.5.1. Lançamento em Lagoas ............................................................. 31

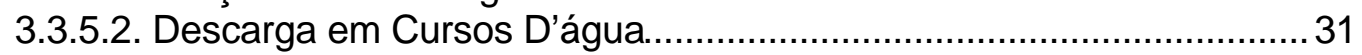

3.3.5.3. Disposição no Solo .......................................................................... 31

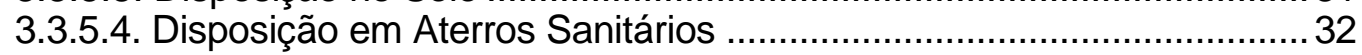

3.3.5.5. Lançamento nas ETEs ................................................................ 32

3.3.5.5.1. Efeitos nos Processos e Operações das ETEs .............................. 33

3.3.5.5.2. Toxicidade em Processos Anaeróbios .......................................... 35

3.3.5.5.3. Toxicidade em Processos Aeróbios ............................................. 36

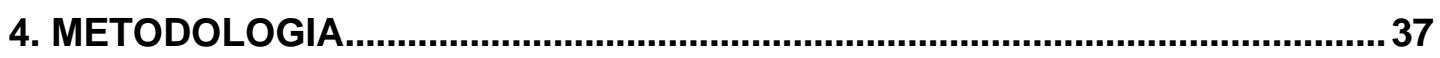

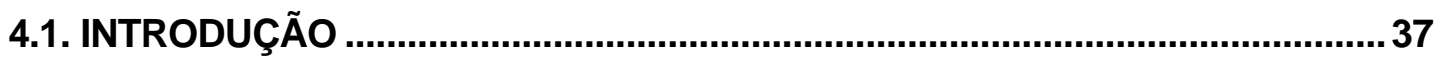

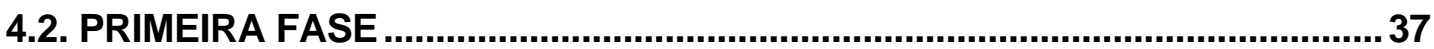

4.2.1. Dados Operacionais da Estação de Tratamento de Água de São Carlos . 39

4.2.2. Obtenção do Esgoto Sanitário................................................................... 39

4.2.3. Obtenção e Caracterização do Resíduo da Limpeza do Decantador ......... 39

4.2.4. Obtenção e Caracterização da Água de Lavagem de Filtro ......................... 40

4.2.5. Descrição das Instalações ................................................................... 41

4.2.5.1. Tanque de Equalização e Homogeneização do Esgoto Sanitário ...... 41

4.2.5.2. Descrição das Colunas de Sedimentação ......................................... 41

4.2.6. Efeitos nos Decantadores Primários de uma ETE .................................... 42

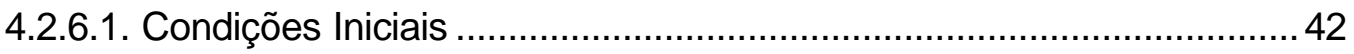

4.2.6.2. Ensaios de Sedimentação ................................................................. 43

4.2.7. Efeitos nos Digestores Anaeróbios de Lodo de ETE................................ 44

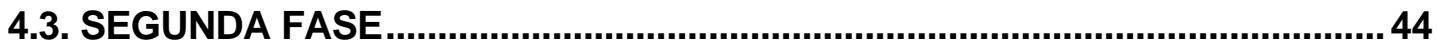

4.3.1. Dados Operacionais da Estação de Tratamento de Esgoto de Araraquara

4.3.1.1. Obtenção do Esgoto Sanitário .......................................................... 48

4.3.2. Dados Operacionais da ETA-Fonte....................................................... 52

4.2.2.1. Obtenção e Caracterização do Resíduo da Descarga dos

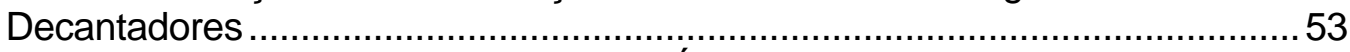

4.3.2.2. Obtenção e Caracterização da Água de Lavagem de Filtro ....................54

4.3.3. Descrição das Instalações em Escala Piloto.................................................55

4.3.3.1. Lagoa de Aeração em Escala Piloto ............................................... 55

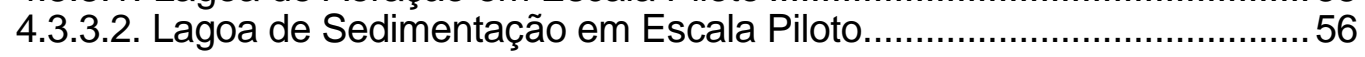

4.3.4. Descrição do Ensaio em Escala Piloto...................................................5 57

4.4. DESCRIÇÃO DOS ENSAIOS EM LABORATÓRIO ...................................... 59

4.4.1. Atividade Metanogênica...................................................................... 59

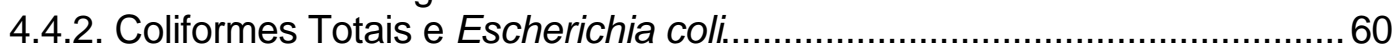

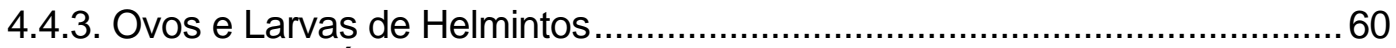

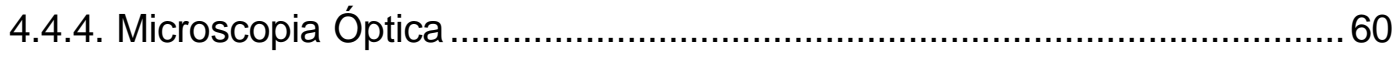

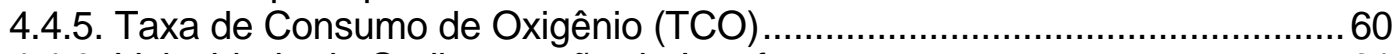

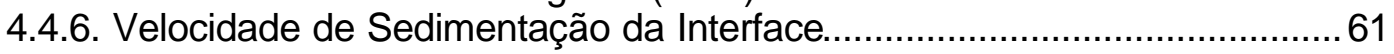

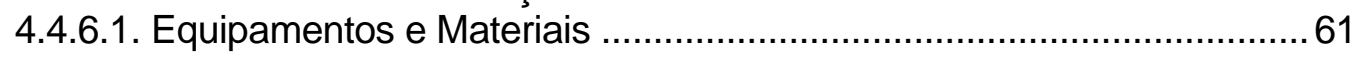

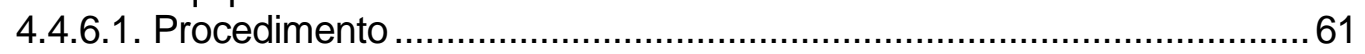


4.4.7. Desidratação do Lodo por Centrifugação

4.4.7.1. Cálculo da Aceleração Centrífuga Aplicada no Equipamento de Laboratório

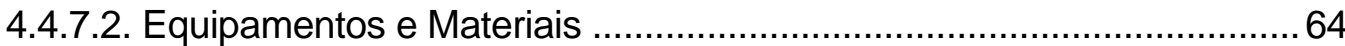

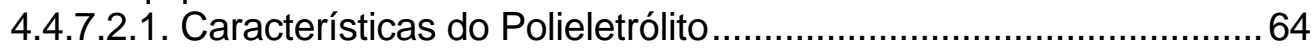

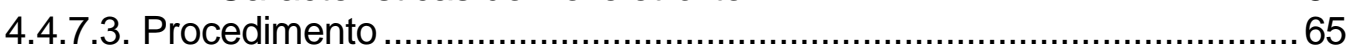

4.4.7.3.1. Coleta e Caracterização do Sobrenadante Após Centrifugação.. 65

4.4.7.3.2. Coleta e Caracterização da Torta de Lodo Após Centrifugação .. 65

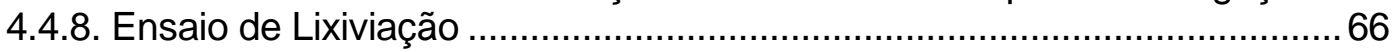

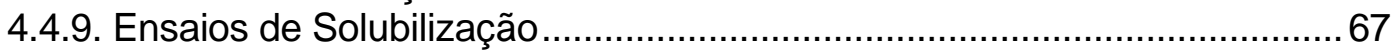

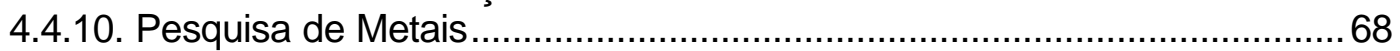

4.4.11. Resistência Específica à Filtração........................................................ 68

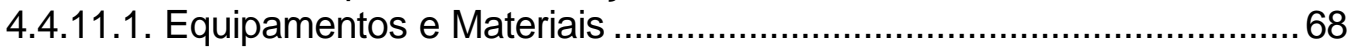

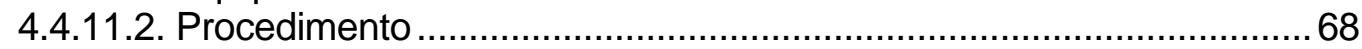

4.4.12. Análises e Exames Laboratoriais ........................................................... 70

5. RESULTADOS E DISCUSSÃO ................................................................. 71

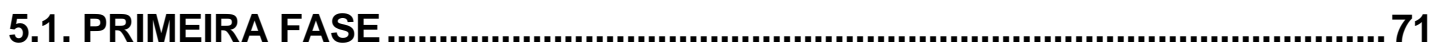

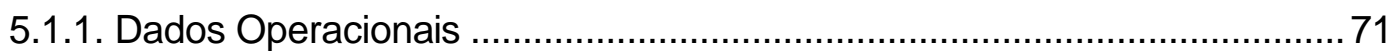

5.1.2. Resíduo da Limpeza do Decantador ....................................................... 72

5.1.3. Resíduo da Lavagem do Filtro - Água de Lavagem de Filtro .................... 73

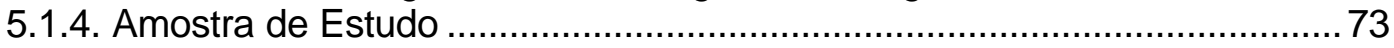

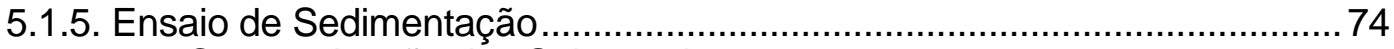

5.1.5.1. Caracterização dos Sobrenadantes .............................................. 77

5.1.5.2. Caracterização dos Sedimentos....................................................... 77

5.1.5.3. Ensaios de toxicidade anaeróbia - Teste da atividade metanogênica 78

5.1.5.3.1. Análise microscópica.................................................................. 80

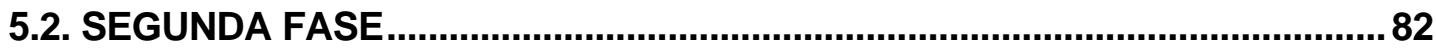

5.2.1. Caracterização do Resíduo da Descarga do Decantador ........................... 83

5.2.2. Caracterização do Resíduo da Lavagem dos Filtros .................................. 84

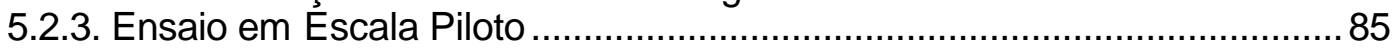

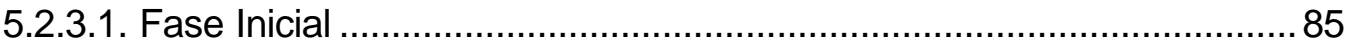

5.2.3.1.1. Caracterização do Afluente e Efluente ........................................ 85

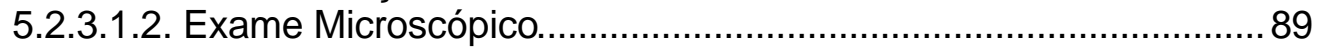

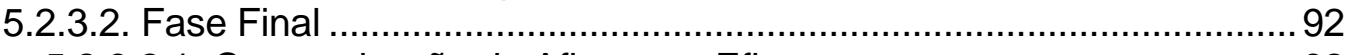

5.2.3.2.1. Caracterização do Afluente e Efluente ...................................... 92

5.2.3.2.2. Taxa de Consumo de Oxigênio e Caracterização do Licor das Lagoas de Aeração ............................................................................. 110

5.2.3.2.3. Ensaio de Sedimentabilidade ................................................. 119

5.2.3.2.4. Exame Microscópico............................................................... 120

5.2.3.2.5. Caracterização do Lodo das Lagoas de Sedimentação .............. 123

5.2.3.1.6. Resistência Específica do Lodo .............................................. 124

5.2.3.1.7. Desidratação do Lodo por Centrifugação .................................. 128

5.2.4.1.7.1. Caracterização do Sobrenadante...................................... 132

5.2.4.1.7.2. Caracterização da Torta de Lodo ...................................... 132

5.2.4.1.7.3. Ensaios de Lixiviação e Solubilização do lodo adensado ... 133

6. CONCLUSÕES E RECOMENDAÇÕES. 137

6.1. CONCLUSÕES REFERENTES À PRIMEIRA FASE DE ESTUDO 137 
6.2. CONCLUSÕES REFERENTES À SEGUNDA FASE DE ESTUDO................138

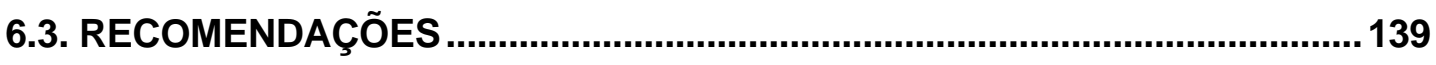

7. REFEFERÊNCIAS BIBLIOGRÁFICAS ..................................................... 141 


\section{LISTA DE FIGURAS}

Figura 3.1 - Esquema de coluna de sedimentação

Figura 3.2 - Gráfico típico da relação t/v em função de v, para obtenção de b no cálculo da resistência específica. 16

Figura 3.3 - Variação de turbidez e de concentração de SST durante a lavagem do filtro de uma ETA que utiliza sulfato de alumínio como coagulante primário. 23

Figura 4.1 - Fluxograma da primeira fase. 38

Figura 4.2 - Fotografia ilustrando a caixa de amianto, com capacidade para $1000 \mathrm{~L}$, que foi responsável pelo armazenamento, e o agitador localizado na parte superior da caixa e a bomba de recalque.

Figura 4.3 - Colunas de sedimentação que foram utilizadas nos ensaios de sedimentação. (A) Fotografia ilustrando as colunas de sedimentação; (B) esquema das colunas de sedimentação. 42

Figura 4.4 - Fluxograma da segunda fase. .45

Figura 4.5 - (A) Bomba de fluxo contínuo, instalada no canal de entrada da ETEAraraquara, responsável para coleta e envio do esgoto sanitário até as bombas dosadoras; (B) Sistema de gradeamento para evitar entupimentos. .. 48

Figura 4.6 - Fluxograma da ETE-Araraquara. 49

Figura 4.7 - Fotografia ilustrando a Lagoa de Aeração da ETE-Araraquara, constituída por aeradores superficiais com potência de $40 \mathrm{cv}$. 50 Figura 4.8 - Fotografia ilustrando as Lagoas de Aeração e de Sedimentação da ETE-Araraquara. 50

Figura 4.9 - Relação entre o volume total de água tratada pelo DAAE-Araraquara e ETA-Fonte e o volume de resíduo gerado nas descargas dos decantadores e lavagens dos filtros. 
Figura 4.10 - (A) Fotografia durante a descarga; (B) Fotografia da saída do canal que recebe o resíduo das descargas dos decantadores da ETA-Fonte, onde foram coletadas as amostras para dispor na ETE-Piloto. .54

Figura 4.11 - Dispositivo para controle da vazão do despejo coletado pela bomba submersível, durante a lavagem do filtro. A) Planta; B) Vista lateral. .54 Figura 4.12 - Fotografia dos conjuntos de lagoas em escala piloto, sendo cada um constituído por uma Lagoa de Aeração e uma de Sedimentação. .55 Figura 4.13 - Fotografia da Lagoa de Aeração em escala piloto, composta por 8 difusores de ar e alimentada com esgoto sanitário por uma bomba dosadora.........56 Figura 4.14 - Fotografia da Lagoa de Sedimentação em escala piloto com tempo de detenção de 1,5 dias. .57

Figura 4.15 - Fotografia a direita mostra a aparelhagem utilizada para determinação da resistência específica. No esquema à esquerda estão detalhados os equipamentos e materiais utilizados no teste da resistência específica. 1 - funil de Buchner nீ 2; 2 - bomba de vácuo; 3 - cronômetro; 4 - manômetro; 5 - proveta graduada de $25 \mathrm{~mL}$ com dispositivo para tomada de vácuo; 6 - papel de filtro Whatman $n^{\circ} 42 ; 7$ - anel em borracha vedante para funil de Buchner encaixar na proveta; 8 - mangueira para ligar a proveta a bomba; e 9 - cadinho de porcelana.. 69 Figura 5.1 - Freqüência da limpeza dos decantadores e volume de resíduo gerado na ETA-SC durante o ano de 1999.

Figura 5.2 - Concentração de SST medidos nas amostras obtidas, em intervalos de 20 minutos, no ponto de coleta 1 de todas colunas da bateria. 75 Figura 5.3 - Concentração de SST medidos nas amostras obtidas, em intervalos de 20 minutos, no ponto de coleta 2 de todas colunas da bateria. 76 Figura 5.4 - Concentração de SST medidos nas amostras obtidas, em intervalos de 20 minutos, no ponto de coleta 3 de todas colunas da bateria. 76 Figura 5.5 - Concentração de metano obtida nos frascos-reator durante o teste de atividade metanogênica. 79 Figura 5.6 - (A) Presença de bactérias em forma de bacilos curvos semelhantes às redutoras de sulfato no Frasco-reator controle. (B) Presença de bactérias fluorescentes em forma de bastonetes no Frasco-reator controle. 81 Figura 5.7 - (A) Methanosarcina sp presente no Frasco-reator 1. (B) Pouca quantidade de metanococos fluorescentes presentes no Frasco-reator 1. 81 Figura 5.8 - (A) Methanothrix sp presentes no frasco-reator 2. (B) Methanothrix sp no frasco-reator 3 . 
Figura 5.9 - (A) Bactéria filamentosa Beggiatoa spp. Observe a presença de grânulos de enxofre. (B) Presença deVorticella spp, pertencente a Classe Ciliata, sendo um ciliado pedunculado. .90

Figura 5.10 - (A) Nematóide, indicativo de boas condições de depuração. (B) Lodo com boas características, onde se observa Colônia de Epistylis spp pertencente ao grupodos ciliados pedunculados. 90

Figura 5.11 - (A) Rizopode semelhante a Amoeba pertencente à classe Sarcodina. Indica lodo jovem, característica de início de operação. (B) Ciliado livre-natante do gênero Paramecium spp. Indicativo de boa depuração. .90

Figura 5.12 - (A) Anelídeos do gênero Aelosoma. Em grande quantidade indica excesso de OD. (B) Ciliado livre natante semelhante a Trachelophyllum spp, pertencente a Classe Ciliata. Indicativo de boas condições de depuração. .91 Figura 5.13 - (A) Rizópode com teca semelhante à Arcella, pertencente a Classe Sarcodina (amebas) e Bactéria filamentosa Beggiatoa spp. (B) Presença de Aspidisca sp, sendo um ciliado livre, predador de flocos. Indicativo de Nitrificação.

Figura 5.14 - (A) Espécie semelhante ao gênero Euplotes spp, sendo um ciliado livre, predador de flocos. (B) Bactérias em forma de bacilos. Pode ser indicativo de início de operação.

Figura 5.15 - Valores de DQO e DBO nos efluentes das lagoas de sedimentação durante o período de operação das ETEs-piloto. Lagoa 1 pertecente ao conjunto que recebeu resíduo da ETA-Fonte. Lagoa 2 pertencente ao conjunto que não recebeu resíduo da ETA-Fonte. 106

Figura 5.16 - Concentração de Sólidos Totais (ST), Sólidos Fixos (SF) e Sólidos Voláteis (SV) nos efluentes das lagoas de sedimentação durante o período de operação das ETEs-piloto. Lagoa 1 pertecente ao conjunto que recebeu resíduo da ETA-Fonte. Lagoa 2 pertencente ao conjunto que não recebeu resíduo da ETAFonte. 106

Figura 5.17 - Concentração SDT, SDF e SDV nos efluentes das lagoas de sedimentação durante o período de operação das ETEs-piloto. Lagoa 1 pertecente ao conjunto que recebeu resíduo da ETA-Fonte. Lagoa 2 pertencente ao conjunto que não recebeu resíduo da ETA-Fonte. 107 Figura 5.18 - Concentração de SST, SSF e SSV nos efluentes das lagoas de sedimentação durante o período de operação das ETEs-piloto. Lagoa 1 pertecente 
ao conjunto que recebeu resíduo da ETA-Fonte. Lagoa 2 pertencente ao conjunto que não recebeu resíduo da ETA-Fonte. 107

Figura 5.19 - Valores de Turbidez, Cor aparente e concentração de Cloreto nos efluentes das lagoas de sedimentação durante o período de operação das ETEspiloto. Lagoa 1 pertecente ao conjunto que recebeu resíduo da ETA-Fonte. Lagoa 2 pertencente ao conjunto que não recebeu resíduo da ETA-Fonte. 108 Figura 5.20 - Concentração de Nitrogênio amoniacal e Nitrito nos efluentes das lagoas de sedimentação durante o período de operação das ETEs-piloto. Lagoa 1 pertecente ao conjunto que recebeu resíduo da ETA-Fonte. Lagoa 2 pertencente ao conjunto que não recebeu resíduo da ETA-Fonte. 108

Figura 5.21 - Concentração de Nitrato, NTK e Fosfato total nos efluentes das lagoas de sedimentação durante o período de operação das ETEs-piloto. Lagoa 1 pertecente ao conjunto que recebeu resíduo da ETA-Fonte. Lagoa 2 pertencente ao conjunto que não recebeu resíduo da ETA-Fonte. 109 Figura 5.22 - Concentrações dos metais $\mathrm{Mn}, \mathrm{Cd}$, Cu e Co nos efluentes finais durante o período de operação das ETEs-piloto. Lagoa 1 pertecente ao conjunto que recebeu resíduo da ETA-Fonte. Lagoa 2 pertencente ao conjunto que não recebeu resíduo da ETA-Fonte. 109 Figura 5.23 - Concentrações dos metais $\mathrm{Fe}, \mathrm{Ni}, \mathrm{Zn}, \mathrm{Pb}$ e $\mathrm{Cr}$ nos efluentes finais durante o período de operação das ETEs-piloto. Lagoa 1 pertencente ao conjunto que recebeu resíduo da ETA-Fonte. Lagoa 2 pertencente ao conjunto que não recebeu resíduo da ETA-Fonte. 110 Figura 5.24 - Valores de OD em função do tempo utilizado para determinação da TCO na lagoa de aeração que recebeu resíduo de ETA-Fonte. No detalhe observe o trecho linear da curva. Ensaio realizado no dia 2 de maio de 2003.

Figura 5.25 - Valores de OD em função do tempo utilizado para determinação da TCO na lagoa de aeração que não recebeu resíduo de ETAFonte. No detalhe observe o trecho linear da curva. Ensaio realizado no dia 2 de maio de 2003......117 Figura 5.26 - Valores de OD em função do tempo utilizado para determinação da TCO na lagoa de aeração que recebeu resíduo de ETA-Fonte. No detalhe observe o trecho linear da curva. Ensaio realizado no dia 14 de maio de 2003. 118 Figura 5.27 - Valores de OD em função do tempo utilizado para determinação da TCO na lagoa de aeração que não recebeu resíduo de ETAFonte. No detalhe observe o trecho linear da curva. Ensaio realizado no dia 14 de maio de 2003... 118 
Figura 5.28 - Ensaio de Sedimentabilidade dos licores mistos das lagoas de aeração realizado em Cone Imhoff em função do tempo. Ensaio realizado no dia 14 de maio de 2003. 120

Figura 5.29 - Aspidisca spp no licor da lagoa de aeração que recebeu resíduo de ETA. É um ciliado livre rastejante, predador de flocos. Indicativo de Nitrificação. (B) Presença de rotífero do gênero Philodina no licor da lagoa de aeração que recebeu resíduo de ETA.

Figura 5.30 - (A) Presença de ciliado livre-natante do gênero Trachelophyllum no licor da lagoa de aeração que recebeu resíduo de ETA. Indicativo de $\theta_{c}$ alto. (B) Presença de ciliado livre-natante do gênero Paramecium no licor da lagoa de aeração que recebeu resíduo de ETA.

Figura 5.31 - (A) Presença de ciliado livre-natante do gênero Paramecium no licor da lagoa de aeração que recebeu resíduo de ETA. (B) Presença de cisto de ovo ou cisto de rotífero no licor da lagoa de aeração que recebeu resíduo de ETA. 122 Figura 5.32 - (A) Presença de ciliado livre-natante semelhante ao gênero Litonotus no licor da lagoa de aeração que recebeu resíduo de ETA. (B) Presença de ciliado semelhante a Coleps hirtus no licor da lagoa de aeração que recebeu resíduo. .. 122 Figura 5.33 - (A) Presença de ciliado livre no licor da lagoa de aeração que não recebeu resíduo de ETA. (B)Presença de nematóide no licor da lagoa de aeração que não recebeu resíduo de ETA 122 Figura 5.34 - (A) Presença de ciliado semelhante ao gênero Aspidisca no licor da lagoa de aeração que não recebeu resíduo de ETA. (B) Organismo semelhante a cloroflagelado presente no licor da lagoa de aeração que não recebeu resíduo de ETA 123

Figura 5.35 - (A) Organismo semelhante a diatomácea presente no licor da lagoa de aeração que não recebeu resíduo de ETA. (B) - Organismo semelhante a alga verde presente no licor misto da lagoa de aeração que não recebeu resíduo. ...... 123 Figura 5.36- Relação t/v em função do volume filtrado, utilizado no cálculo da resistência específica do lodo da lagoa de sedimentação proveniente da ETE-piloto que recebeu resíduo da ETA-Fonte. $\mathrm{SST}_{\mathrm{i}}=28,20 \mathrm{~g} / \mathrm{L}$ 127 Figura 5.37 - Relação t/v em função do volume filtrado, utilizado no cálculo da resistência específica do lodo da lagoa de sedimentação proveniente da ETE-piloto que recebeu resíduo da ETA-Fonte. $\mathrm{SST}_{\mathrm{i}}=32,0 \mathrm{~g} / \mathrm{L}$ 127 
Figura 5.38 - Teores de SST em função do empo de centrifugação para as diferentes concentrações de polieletrólito empregadas no lodo proveniente da lagoa de sedimentação que recebeu resíduo de ETA. 131 Figura 5.39 - Teores de SST em função do tempo de centrifugação para as diferentes concentrações de polieletrólito empregadas no lodo proveniente da lagoa de sedimentação que não recebeu resíduo de ETA. 131 


\section{LISTA DE TABELAS}

Tabela 3.1 - Parâmetros físicos determinados por pesquisadores brasileiros para resíduos provenientes da descarga de decantadores. 10 Tabela 3.2 - Parâmetros físicos determinados por pesquisadores brasileiros, na década de 90, para resíduos gerados nas lavagens de filtros. 11 Tabela 3.3 - Valores típicos da resistência específica para diferentes tipos de lodo de ETEs.

Tabela 3.4 - Resultados de exames bacteriológicos realizados no resíduo líquido proveniente da lavagem de filtros de diferentes ETAs, segundo alguns autores. ...20 Tabela 3.5 - Desempenho típico de centrífugas no desaguamento de lodos 28 Tabela 4.1 - Parâmetros que foram medidos no resíduo da descarga do decantador utilizado no ensaio de sedimentação 40 Tabela 4.2 - Parâmetros que foram medidos na água de lavagem de filtro utilizada no ensaio de sedimentação. 40

Tabela 4.3 - Dados de projeto de construção da ETE-Araraquara 47 Tabela 4.4 - Valores gastos na construção da ETE-Araraquara, emissários e compras de equipamentos.

Tabela 4.5 - Valores médios dos parâmetros analisados no ano de 2002 para o afluente e efluente da ETE-Araraquara.

Tabela 4.6 - Volume Total de água tratada pelo DAAE em comparação ao volume de água aduzido à ETA-Fonte e volume gerado nas descargas dos decantadores e lavagens de filtros, no ano de 2002. 52 Tabela 4.7 - Parâmetros para caracterização do afluente e efluente da ETE-Piloto.

Tabela 4.8 - Limite máximo permitido dos poluentes presentes no extrato obtido no ensaio de Lixiviação. 66 
Tabela 4.9 - Limite máximo permitido dos poluentes presentes no extrato obtido no ensaio de Solubilização.

Tabela 4.10 - Métodos e Equipamentos empregados para determinação dos parâmetros físico-químicos e bacteriológicos utilizados na parte experimental. Com exceção da análise de Nitrato, os demais parâmetros seguem os métodos contidos no "Standard Methods for the examination of Water and Wastewater" publicado pela APHA (1998) 70

Tabela 5.1 - Caracterização dos resíduos da limpeza do decantador, utilizados nos ensaios de sedimentação.

Tabela 5.2 - Caracterização da amostra de água de lavagem de filtro utilizada no ensaio de sedimentação. .73

Tabela 5.3 - Caracterização dos resíduos utilizados nos ensaios de sedimentação.

Tabela 5.4 - Volume do esgoto sanitário e da amostra de resíduo de ETA utilizados no ensaio de sedimentação.

Tabela 5.5 - Concentração de SST em mg/L, medidos nos 3 pontos de coletas de cada coluna em intervalos de 20 minutos até 120 minutos de sedimentação. .75 Tabela 5.6 - Caracterização dos sobrenadantes coletados nas colunas de sedimentação durante o ensaio de sedimentação, simulando um decantador primário de ETE, nos tempos 0,60 e 120 minutos. .77

Tabela 5.7 - Caracterização do sedimento obtido no ensaio de sedimentação........ 78 Tabela 5.8 - Concentração de Sólidos presente no inóculo anaeróbio utilizados nos ensaios de toxicidade anaeróbia. ..................................................................... 78

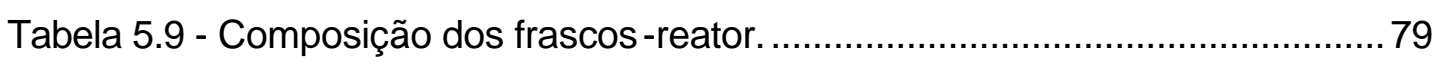

Tabela 5.10 - Caracterização da amostra composta do resíduo da descarga do decantador, coletada dia 24 de janeiro de 2003.

Tabela 5.11 - Caracterização da amostra composta do resíduo da lavagem do filtro, coletada dia 24 de janeiro de 2003.

Tabela 5.12 - Caracterização das amostras do afluente e efluente da ETE-Piloto, coletadas no dia 15/01/2003. 86 Tabela 5.13 - Caracterização das amostras do afluente e efluente da ETE-Piloto, coletadas no dia 24/01/2003.

Tabela 5.14 - Caracterização das amostras do afluente e efluente da ETE-Piloto, coletadas no dia 07/02/2003. .88 
Tabela 5.15 - Caracterização das amostras do afluente e efluente da ETE-Piloto, coletadas no dia 12/02/2003.

Tabela 5.16 - Caracterização das amostras do afluente e efluente da ETE-Piloto, coletadas no dia 19/02/2003.

Tabela 5.17 - Caracterização das amostras do afluente e efluente da ETE-Piloto, coletadas no dia 26/02/2003.

Tabela 5.18 - Caracterização das amostras do afluente e efluente da ETE-Piloto, coletadas no dia 08/03/2003.

Tabela 5.19 - Caracterização das amostras do afluente e efluente da ETE-Piloto, coletadas no dia 19/03/2003.

Tabela 5.20 - Caracterização das amostras do afluente e efluente da ETE-Piloto, coletadas no dia 26/03/2003.

Tabela 5.21 - Caracterização das amostras do afluente e efluente da ETE-Piloto, coletadas no dia 02/04/2003.

Tabela 5.22 - Caracterização das amostras do afluente e efluente da ETE-Piloto, coletadas no dia 09/04/2003. 100

Tabela 5.23 - Caracterização das amostras do afluente e efluente da ETE-Piloto, coletadas no dia 16/04/2003. 101

Tabela 5.24 - Caracterização das amostras do afluente e efluente da ETE-Piloto, coletadas no dia 23/04/2003. 102

Tabela 5.25 - Caracterização das amostras do afluente e efluente da ETE-Piloto, coletadas no dia 30/04/2003. 103

Tabela 5.26 - Caracterização das amostras do afluente e efluente da ETE-Piloto, coletadas no dia 07/05/2003. 104

Tabela 5.27 - Caracterização das amostras do afluente e efluente da ETE-Piloto, coletadas no dia 14/05/2003. 105

Tabela 5.28 - Nesta tabela estão contidos os resultados da $\mathrm{TCO}_{\mathrm{a}}$ nos licores mistos das lagoas de aeração e as relações $\mathrm{TCO}_{\mathrm{a}} / \mathrm{SSV}$, juntamente com o resultado de alguns parâmetros pesquisados

Tabela 5.29 - Valores de OD em função do tempo, obtidos durante o ensaio para determinação da taxa de consumo de oxigênio na Lagoa de Aeração que recebeu resíduo da ETA-Fonte. Ensaio realizado no 02 de maio de 2003.

Tabela 5.30 - Valores de OD, em função do tempo, obtidos durante o ensaio para determinação da taxa de consumo de oxigênio na Lagoa de Aeração que não recebeu resíduo da ETA-Fonte. Ensaio realizado no dia 02 de maio de 2003...... 114 
Tabela 5.31 - Valores de OD em função do tempo, obtidos durante o ensaio para determinação da taxa de consumo de oxigênio na Lagoa de Aeração que recebeu resíduo da ETA-Fonte. Ensaio realizado no 14 de maio de 2003. 115 Tabela 5.32 - Valores de OD em função do tempo, obtidos durante o ensaio para determinação da taxa de consumo de oxigênio na Lagoa de Aeração que não recebeu resíduo da ETA-Fonte. Ensaio realizado no 14 de maio de 2003. 116 Tabela 5.33 - Concentração de sólidos sedimentáveis em função do tempo. Ensaio realizado em Cone Imhoff no dia 14 de maio de 2003. 119 Tabela 5.34 - Caracterização dos lodos obtidos nas lagoas de sedimentação após término da operação das ETEs-piloto. 125

Tabela 5.35 - Tempo de filtração dos lodos obtidos nas lagoas de sedimentação das ETEs-piloto, em função do volume, utilizado no teste da resistência específica. 126

Tabela 5.36 - Valores de resistência específica nos lodos das lagoas de sedimentação. 126

Tabela 5.37 - Volume de sólidos no fundo do tubo em função do tempo de centrifugação para as diferentes concentrações de polieletrólito empregada no ensaio utilizando lodo da lagoa de sedimentação que recebeu resíduo de ETA... 129 Tabela 5.38 - Teor de SST, nos lodo em função do tempo de centrifugação para as diferentes concentrações de polieletrólito empregada no ensaio utilizando lodo da lagoa de sedimentação que recebeu resíduo de ETA. 129 Tabela 5.39 - Volume de sólidos no fundo do tubo em função do tempo de centrifugação para as diferentes concentrações de polieletrólito empregada no ensaio utilizando lodo da lagoa de sedimentação que não recebeu resíduo de ETA.

Tabela 5.40 - Teor de SST, nos lodo em função do tempo de centrifugação para as diferentes concentrações de polieletrólito empregada no ensaio utilizando lodo da lagoa de sedimentação que não recebeu resíduo de ETA. 130

Tabela 5.41 - Caracterização dos sobrenadantes obtidos dos melhores resultados no ensaio de centrifugação 132 Tabela 5.42 - Caracterização das tortas de lodo obtidas dos melhores resultados no ensaio de centrifugação. 133

Tabela 5.43 - Informações obtidas durante os ensaios de lixiviação. 133

Tabela 5.44 - Informações obtidas durante os ensaios de solubilização. 134 
Tabela 5.45 - Resultados dos poluentes pesquisados nos extratos do lixiviado e do solubilizado da torta obtida no ensaio de centrifugação com o lodo da lagoa de sedimentação proveniente da ETE-piloto que recebeu resíduo da ETA-Fonte, juntamente com seus limites máximos permitidos, de acordo com a NBR 10004/1987 Anexo G Listagem nீ 7 - Concentração - limite máximo no extrato obtido no teste de lixiviação e NBR 10004/1987 Anexo H Listagem n 8 - Padrões para o teste de solubilização. 135

Tabela 5.46 - Resultados dos poluentes pesquisados nos extratos do lixiviado e do solubilizado da torta obtida no ensaio de centrifugação com o lodo da lagoa de sedimentação proveniente da ETE-piloto que não recebeu resíduo da ETAFonte, juntamente com seus limites máximos permitidos, de acordo com a NBR 10004/1987 Anexo G Listagem n 7 - Concentração - limite máximo no extrato obtido no teste de lixiviação e NBR 10004/1987 Anexo H Listagem n 8 - Padrões para o teste de solubilização. 136 


\section{LISTA DE ABREVIATURAS E SIGLAS}

\begin{tabular}{ll}
\hline ABNT & - Associação Brasileira de Normas Técnicas. \\
CETESB & - Companhia de Tecnologia e Saneamento Ambiental. \\
CNPq & - Conselho Nacional de Desenvolvimento Científico e Tecnológico. \\
DAAE & - Departamento Autônomo de Água e Esgoto. \\
DBO & - Demanda Bioquímica de Oxigênio. \\
DQO & - Demanda Química de Oxigênio. \\
EESC & - Escola de Engenharia de São Carlos. \\
ETA & - Estação de Tratamento de Água. \\
ETA-Fonte & - Estação de Tratamento de Água da cidade de Araraquara. \\
ETE & - Estação Tratamento de Esgoto. \\
ETE-Araraquara & - Estação de Tratamento de Esgotos de Araraquara. \\
NMP & - Número mais provável. \\
NTK & - Nitrogênio Total Kjeldahl. \\
OD & - oxigênio dissolvido. \\
PVC & - Cloreto de polivinil. \\
SABESP & - Companhia de Saneamento Básico do Estado de São Paulo. \\
Sól. Sed. & - Sólidos Sedimentáveis. \\
ST & - Sólidos Totais. \\
SF & - Sólidos Fixos. \\
SV & - Sólidos Voláteis. \\
SST & - Sólidos Suspensos Totais. \\
SSF & - Sólidos Suspensos Fixos. \\
SSV & - Sólidos Suspensos Voláteis. \\
SDT & - Sólidos Dissolvidos Totais. \\
SDF & - Sólidos Dissolvidos Fixos. \\
SDV & - Sólidos Dissolvidos Voláteis. \\
USP & - Universidade de São Paulo. \\
\hline ST &
\end{tabular}




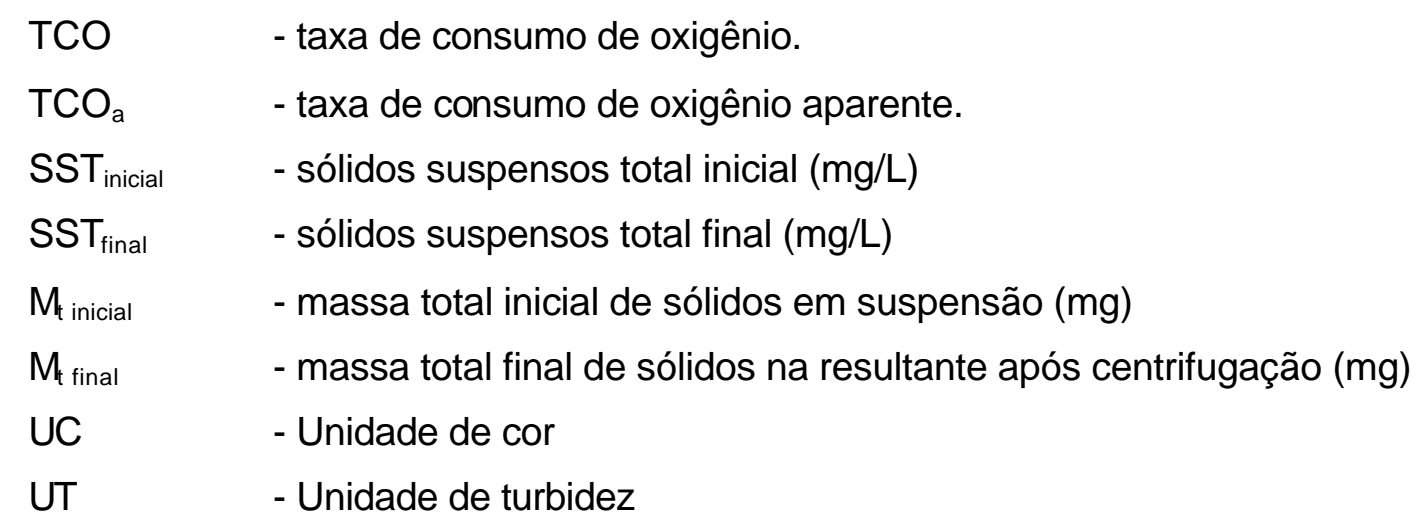




\section{LISTA DE SÍMBOLOS}

\begin{tabular}{|c|c|}
\hline r & - resistência específica $(\mathrm{cm} / \mathrm{g})$ \\
\hline $\mathrm{P}$ & - pressão de filtração $\left(\mathrm{g} / \mathrm{cm}^{3}\right)$ \\
\hline A & - área filtrante $\left(\mathrm{cm}^{2}\right)$ \\
\hline$\mu$ & - viscosidade do filtrado (g/cm.s) \\
\hline $\mathrm{C}$ & - massa de sólidos suspensos por unidade de volume filtrado $\left(\mathrm{g} / \mathrm{cm}^{3}\right)$ \\
\hline b & - inclinação da reta de $t / v$ versus $v\left(s / \mathrm{cm}^{6}\right)$ \\
\hline $\mathrm{t}$ & - tempo de filtração (s) \\
\hline $\mathrm{v}$ & - volume filtrado $\left(\mathrm{cm}^{3}\right)$ \\
\hline $\mathrm{A} / \mathrm{M}$ & - relação alimento/microrganismo \\
\hline g & - aceleração da gravidade $\left(\mathrm{m} / \mathrm{s}^{2}\right)$ \\
\hline $\mathrm{R}$ & - raio de rotação até a extremidade do tubo $(\mathrm{cm})$ \\
\hline $\mathrm{N}$ & - rotação da centrífuga (rpm) \\
\hline $\mathrm{V}_{\mathrm{c}}$ & - volume resultante de torta após centrifugação (L) \\
\hline$a_{c}$ & - aceleração centrífuga $\left(\mathrm{m} / \mathrm{s}^{2}\right)$ \\
\hline W & - velocidade da centrifugação (m/s) \\
\hline$\theta_{\mathrm{c}}$ & - tempo de retenção celular \\
\hline$V_{t}$ & - volume total da suspensão (L) \\
\hline
\end{tabular}




\title{
RESUMO
}

\author{
SCALIZE, P.S. (2003). Disposição de resíduos gerados em estações de tratamento de água \\ em estação de tratamento de esgoto. São Carlos, 2003 Tese (Doutorado) - Escola de \\ Engenharia de São Carlos, Universidade de São Paulo.
}

O presente trabalho foi realizado em duas fases. Na primeira, foram estimados os efeitos produzidos nos decantadores primários de uma ETE, após receber resíduo da ETASC, que utiliza sulfato de alumínio como coagulante. Foram realizados ensaios em colunas de sedimentação, onde os parâmetros SST, SSV, cor, turbidez, DQO, coliformes totais, Escherichia coli e parasitas, pesquisados no sobrenadante, diminuíram com o aumento da quantidade de resíduo adicionado. Com relação aos sedimentos obtidos nas colunas de sedimentação, foi encontrada maior quantidade de ST e menor resistência específica nos lodos provenientes das colunas que receberam os resíduos da ETA-SC. No teste de atividade metanogênica, a concentração molar de metano foi reduzida nos sistemas que receberam resíduo da ETA-SC, influenciando negativamente no desenvolvimento dos microrganismos metanogênicas. As espécies de microrganismos do gênero Methanothrix $s p$ foram inibidas, sendo encontradas em maior número no frasco-reator controle e em menor quantidade a medida que se aumentou a quantidade do resíduo adicionado. Nesta etapa foi constatado que o resíduo da ETA-SC poderá apresentar interferências negativas sobre a digestão anaeróbia do lodo produzido em decantadores primários de uma ETE.

$\mathrm{Na}$ segunda fase, na estação piloto, composta de lagoa de aeração seguida de lagoa de sedimentação, que recebeu resíduo da ETA-Fonte, que utiliza cloreto férrico como coagulante, foi verificado que tal resíduo melhorou a qualidade do efluente em termos de DQO, DBO, SST, turbidez, cor, amônio, ritrato, NTK e fosfato total. Os parâmetros ST, $\mathrm{SDT}$, cloreto, nitrito, condutividade e pH não apresentaram diferenças significativas. Em relação ao exame microscópico não houve influências negativas no licor misto das lagoas de aeração. O lodo formado nas lagoas de sedimentação piloto apresentou-se em maior quantidade na lagoa que recebeu resíduo da ETA-Fonte. Neste lodo a resistência específica a filtração foi menor em comparação ao lodo da lagoa que não recebeu resíduo da ETAFonte. A desidratação deste lodo por centrifugação necessitou menor quantidade de polieletrólito. Baseado neste estudo não foi verificado interferências que possa impedir o lançamento do resíduo da ETA-Fonte na ETE-Araraquara.

PALAVRAS-CHAVE: resíduos de ETA, tratabilidade de lodos, lodo de ETA, lodo de ETE. 


\title{
ABSTRACT
}

\author{
SCALIZE, P.S. (2003). Disposal of water treatment plants sludge in wastewater treatment \\ plants. São Carlos, 2003 Tese (Doutorado) - Escola de Engenharia de São Carlos, \\ Universidade de São Paulo.
}

This work was carried out in two phases. Effects of disposing the residues from a water treatment plant - ETASC, which uses alum as primary coagulant on the primary settling tanks was evaluated in the first one. Sedimentation tests using column indicated that parameters such as TSS, VSS, colour, turbidity, COD, total coliformes totais, Escherichia coli e parasites in the supernatant decreased with the increase of the amount of the water treatment wastes added to the column. With relation to the sediments produced in the column, it was found great amount of TS and lower specific solids resistance in those generated in the columns where the water treatment plant residues-WTPR were used. Molar concentration of methane was reduced in the tests performed with the sediments produced with water treatment plant residues and thus, altering negatively the development of methanogenic organisms. The growth of species of microorganism of genera Methanothrix $s p$ was inhibited, which were found in great number in the control flask (with out WTPR) and in lower number as it was increased the amount of WTPR added to the column. It was observed that the WTPR generated in the city water treatment plant may interfere in the anaerobic digestion of sludge produced in primary settling tanks of a waste treatment plant.

A continuous pilot plant was operated in the second phase, which consisted of two aerated lagoon each one followed by a settling lagoon. Waste and WTPR from a watter treatment plant which uses ferric chloride were fed in one of the systems. It was observed that the use of WTPR improved the effluent quality of the settling lagoon evaluated in terms of COD, BOD, TSS, turbidity, color, ammonium, nitrate, TKN and total phosphate. Some parameters, such as TS, TDS, chloride, nitrite, conductivity and $\mathrm{pH}$ did not present significant differences in both systems. Microscopic examinations indicated that no influence resulted in the aerated lagoon mixed liquor. A higher amount of sludge was formed in the lagoon system which received the WTPR. The specific resistance to filtration of this sludge was lower than that formed in the lagoon system with out WTPR addition. When dewatering both sludges, that one produced with the addition of WTPR required less amount of polymer. It was concluded that the WTPR produced in the water treatment plant of Araraquara may be disposed in the city wastewater treatment plant.

KEY-WORDS: water treatment plant residues; wastewater treatment plant sludge. 


\section{INTRODUÇÃO}

Já é nítida a escassez de mananciais de boa qualidade em certas regiões do Brasil devido à crescente demanda de água para consumo humano e ao alto grau de poluição e contaminação dos mesmos, tornando-se cada vez mais importante o estudo de técnicas de recuperação para reaproveitamento de parcela dos resíduos freqüentemente lançados ao curso de água. Os resíduos gerados nas Estações de Tratamento de Água (ETAs), provêm, essencialmente, dos decantadores e filtros. Floculadores e tanques de preparo de soluções e suspensões de produtos químicos produzem resíduos por ocasião das lavagens periódicas em menores volumes.

Em muitos países, as estações de tratamento de água são consideradas indústrias, devendo os resíduos decorrentes da lavagem de filtros, limpeza de decantadores e de tanques de preparação de soluções e suspensões de produtos químicos, etc., serem devidamente tratados, pois apresentam substâncias prejudiciais ao meio ambiente. Os resíduos gerados com as descargas dos decantadores representam uma parcela relativamente pequena do volume de água tratada, com quantidade elevada de sólidos e materiais indesejáveis, devendo portanto, ser tratados, e os sedimentos dispostos convenientemente. Já os resíduos provenientes das lavagens dos filtros representam, em geral, de 1 a $5 \%$ do volume de água tratada, diariamente, sendo viável a sua recuperação, pois isso contribuirá de alguma forma para o atendimento da crescente demanda de água.

No Brasil, um dos aspectos que vem dificultando o emprego de sistemas de tratamento dos resíduos nas ETAs são os custos envolvidos no processo. $O$ tratamento dos resíduos e a disposição final do lodo resultante, são de grande importância, visto sua constituição e o grande volume produzido, devendo-se enfocar a matéria sobre dois aspectos: a) tratamento dos resíduos para diminuição 
do volume descartado; b) disposição final do efluente líquido e do resíduo sólido atenuando o efeito ao meio ambiente.

Historicamente, a prática mais comum tem sido o lançamento dos resíduos diretamente nos cursos de água mais próximos ou utilizando-se a rede de águas pluviais. No entanto, devido às suas características, os resíduos das ETAs aumentam o grau de poluição e contaminação dos corpos receptores, contribuindo para a crescente degradação do meio ambiente e perda da qualidade de vida das populações existentes a jusante desses lançamentos. Tal prática tem sido bastante questionada por causa dos possíveis riscos à saúde pública e à vida aquática. Por outro lado, os sistemas de tratamento convencionais utilizados para os resíduos estão tornando-se complexos e onerosos, visto que os padrões de lançamento em cursos de água e disposição final em aterros sanitários têm se tornado cada vez mais rígido, segundo CORNWELL \& KOPPERS (1990).

Os resíduos de ETAs apresentam grande potencial de poluição e contaminação devido a presença de impurezas removidas da água bruta, de compostos químicos resultantes da adição de coagulantes e condicionantes, durante o processo de tratamento. Dependendo das características da água bruta, pode-se ter maior ou menor presença de material orgânico e inorgânico. Em geral, a maior parcela é de natureza inorgânica, formada por areia, argila e silte, e a parte orgânica constituída de substâncias húmicas que conferem cor à água, organismos planctônicos, bactérias, protozoários, vírus, etc.

Um método de disposição alternativo que tem sido considerado em alguns países da Europa e nos Estados Unidos, é o lançamento dos resíduos de ETAs em estações de tratamento de esgoto (ETEs), via rede coletora de esgoto ou transporte. Tal procedimento surge como uma proposta atraente, visto que elimina a implantação de sistemas de tratamento de resíduos nas ETAs.

Entretanto, algumas interferências podem ocorrer nas unidades da ETE, de maneira que tal procedimento deve ser criteriosamente analisado, destacando-se os digestores de lodo anaeróbios e aeróbios e os decantadores primários, já que, devido às características físicas dos resíduos da ETA, estas unidades receberão a maior parte das impurezas contidas nesses resíduos segundo CORNWELL \& kOPPERS (1990). 


\section{OBJETIVOS}

O presente trabalho teve como objetivo a realização de estudos simulando o lançamento de resíduos de Estação de Tratamento de Água em uma Estação de Tratamento de Esgoto, divididos em duas fases:

Primeira fase - verificar as possíveis interferências após o lançamento de resíduo de uma Estação de Tratamento de Água que utiliza sulfato de alumínio como coagulante primário em uma Estação de Tratamento de Esgoto, em escala piloto, constituída por decantadores primários e digestores aneróbios de lodo.

Segunda fase - verificar as possíveis interferências após o lançamento de resíduo de uma Estação de Tratamento de Água que utiliza cloreto férrico como coagulante primário em uma Estação de Tratamento de Esgoto, em escala piloto, constituída por lagoa de aeração e lagoa de sedimentação. 


\section{REVISÃO DA LITERATURA}

\subsection{CONCEITO DOS RESÍDUOS GERADOS NAS ETAS}

Neste trabalho, o termo resíduo de ETA será referente somente àqueles provenientes da limpeza dos decantadores e lavagens dos filtros. Deve ser entendido como sendo o efluente resultante da limpeza ou descarga dos decantadores e da lavagem dos filtros.

\subsubsection{Origem dos Resíduos Gerados em ETAs}

Os resíduos gerados em ETAs, provêm, essencialmente, da limpeza dos decantadores, lavagem dos filtros, floculadores e tanques de preparação e armazenamento de produtos químicos, tais como tanques de preparos de soluções, sendo a solução de cal a mais utilizada, e de armazenamento de produtos químicos, como por exemplo cloreto férrico, sulfato de alumínio e flúor.

\subsubsection{Limpeza dos Decantadores}

A remoção dos sólidos acumulados em um decantador convencional pode ser efetuada manual ou mecanicamente.

Os decantadores com limpeza manual, geralmente, são esvaziados em intervalos de 30 a 60 dias de funcionamento, dependendo das características da água bruta. A limpeza ocorre através da abertura de registros de fundo e, superficialmente com auxílio de mangueiras sob alta pressão. GRANDIN (1992), 
relata que para este tipo de resíduo as concentrações de sólidos totais estão entre 4 e $13 \%$, e o volume de resíduo gerado representa uma parcela muito pequena, cerca de 0,06 a 0,25\% do volume de água tratada. Segundo CASTRO et al. (1997a), o resíduo líquido gerado durante a descarga dos decantadores da ETA rio das Velhas na Região Metropolitana de Belo Horizonte, a qual utiliza sulfato de alumínio como coagulante primário, apresentou concentrações de sólidos totais variando de 14,90 a 60,79 $\mathrm{g} / \mathrm{l}$, sendo que o volume descartado foi de 0,21 a 2,92 \% da água bruta.

CORDEIRO (1993), encontrou valores de 30,175 g/L para sólidos totais e 27,891 g/L para sólidos suspensos totais na ETA da cidade de São Carlos - SP que utiliza sulfato de alumínio como coagulante primário.

ETAs que utilizam a limpeza mecanizada dos decantadores, produzem, segundo GRANDIN (1992), resíduos com 0,1 a $1 \%$ de sólidos totais, utilizando raspadores e bombeamento intermitente.

Outro tipo de decantador, muito difundido na década de setenta, é o de alta taxa, construídos, principalmente, em reformas de decantadores convencionais, sendo que são realizadas descargas de fundo diárias, para remoção dos sólidos retidos em seu interior. CARVALHO (1999) constatou que uma ETA com este tipo de tecnologia e que utiliza cloreto férrico como coagulante primário, originou resíduos com concentrações de sólidos totais entre $0,70 \mathrm{~g} / \mathrm{L}$ e $4,75 \mathrm{~g} / \mathrm{L}$ e de sólidos suspensos totais entre $0,41 \mathrm{~g} / \mathrm{L} \mathrm{e} 4,50 \mathrm{~g} / \mathrm{L}$.

Segundo GRANDIN (1992), a limpeza manual resulta em resíduos mais concentrados que os obtidos pela remoção mecanizada.

\subsubsection{Lavagem dos Filtros}

Segundo CORNWELL \& LEE (1994), água de lavagem de filtro e descarga de decantadores tem sido lançados na rede de esgoto, no curso de água ou recirculada para o início da estação de tratamento. Diz ainda que para volumes pequenos esta descarga é o método mais apropriado, mas quando o volume for maior, tal prática não é desejável economicamente.

O método, a duração e a periodicidade das lavagens, dentre outros fatores, determinam a qualidade e quantidade dos resíduos gerados, sendo compostos 
principalmente por partículas argilosas muito finas, que não sedimentam nos decantadores.

A lavagem dos filtros, geralmente, é realizada em intervalos de 12 a $48 \mathrm{~h}$ e, o tempo de lavagem entre 4 e $15 \mathrm{~min}$, sendo o final da lavagem determinado pela observação da clarificação da água presente sobre o leito filtrante.

Existem casos em que a duração da carreira de filtração não é obedecida, sendo a lavagem dos filtros executada de maneira aleatória, como por exemplo, por motivos de operação, onde todos filtros são lavados em um curto período de tempo, ocasião em que o consumo de água tratada é menor, ou seja, das 24:00 às 06:00 h, implicando em um resíduo com menor concentração de sólidos. Outro fato, por motivos também operacionais, é a lavagem do filtro mais sujo da bateria em cada turno de trabalho, originando resíduos menos concentrados e, devido ao número de vezes que são lavados, um maior volume de água.

Os principais métodos de lavagem de filtros citados por DI BERNARDO (1993) estão citados a seguir:

- lavagem somente com água, no sentido ascensional;

- lavagem auxiliar superficial com tubulação fixa ou com torniquetes hidráulicos e lavagem simultânea (ou não) com água no sentido ascensional;

- lavagem auxiliar sub-superficial com tubulação fixa e lavagem simultânea (ou não) com água no sentido ascensional;

- insuflação de ar, seguida da lavagem com água no sentido ascensional;

- insuflação de ar e introdução simultânea de água no sentido ascensional

O volume de resíduos gerados e a concentração de sólidos apresentada nos resíduos de lavagem de filtros estão diretamente relacionados com o método de lavagem. O método de insuflação de ar e introdução de água o que gera menor volume de resíduo, apresentando maior concentração de sólidos.

SCALIZE (1997), relata que durante a lavagem de filtros rápidos, em uma ETA que utiliza sulfato de alumínio como coagulante primário, os resíduos podem atingir picos de turbidez e SST da ordem de $100 \mathrm{uT}$ e $200 \mathrm{mg} / \mathrm{L}$, respectivamente, e a amostra homogênea apresentou valores de turbidez da ordem de 60uT e de SST entre 56 e $79 \mathrm{mg} / \mathrm{L}$.

SOUZA FILHO (1998), em seu trabalho utilizando água de lavagem de filtro rápido, que utiliza cloreto férrico como coagulante primário, encontrou picos de turbidez e SST de 500 a $700 \mathrm{uT}$ e 800 a $1400 \mathrm{mg} / \mathrm{L}$, respectivamente, sendo que na 
amostra homogênea os valores máximos foram de $250 \mathrm{uT}$ para turbidez e $400 \mathrm{mg} / \mathrm{L}$ de SST. CARVALHO (1999), em estudos na mesma ETA encontrou valores de turbidez, para amostras homogêneas, entre 150 e 288 UT e de SST entre 137 e $491 \mathrm{mg} / \mathrm{L}$.

Analisando os dois casos acima, pode ser observado que a concentração de SST variou de uma ETA para outra, evidenciando que os resultados obtidos no estudo para um determinado resíduo não pode ser empregado para outro. Além disso, a qualidade da água bruta utilizada em diferentes ETAs, apresentam características próprias, influenciando diretamente na qualidade do resíduo gerado e na sua forma de tratamento.

Segundo CASTRO et al. (1997a), a ETA Rio das Velhas na Região Metropolitana de Belo Horizonte, produz em forma de resíduo líquido percentuais que variam de $0,96 \%$ a $1,61 \%$, para a água de lavagem de filtros.

\subsection{CARACTERIZAÇÃO}

A caracterização dos resíduos gerados em ETAs, antes e após tratamento, é de suma importância para que se estude o possível impacto ambiental destes ao meio ambiente, bem como para os métodos de desidratação e disposição final, pois estes resíduos são classificados como classe II - não inerte, segundo a NBR 10.004 da ABNT - Associação Brasileira de Normas Técnicas.

É conveniente ressaltar que resultados obtidos para um determinado resíduo não podem ser extrapolados para outro, pois podem ser totalmente diferentes, devido a inúmeros fatores descritos a seguir:

a) Características da água bruta

Os mananciais apresentam características próprias, sendo que a qualidade da água bruta varia entre os mananciais, e, até mesmo em um mesmo manancial durante as diferentes épocas do ano, apresentando variações sazonais significativas, como, por exemplo, mudanças de turbidez e na quantidade de sólidos. Os mananciais podem ainda receber contaminantes vindos da lavoura, tais como agrotóxicos, ou contaminações por esgoto sanitário, resíduos de outras ETAs gerados rio acima, resíduos industriais, e outras, dependendo da região. 
CORDEIRO et al. (1997), relatam que, na cidade de Franca - SP, 3600 hectares de área de preservação ambiental permanente estão sem mata nativa, comprometendo a qualidade da água bruta, que devido a isso foi necessário um aumento de $30 \%$ de produtos químicos para remoção de impurezas, promovendo aumento no número de vezes que os decantadores são limpos, gerando maior volume de resíduo.

b) Produtos químicos utilizados no tratamento

Dependendo do tipo de produtos químicos utilizados no tratamento os resíduos terão características distintas. Vários são os produtos químicos utilizados no tratamento, podendo ser citados coagulantes a base de sais de ferro e alumínio, além de auxiliares no tratamento, tais como polímeros, carvão ativado e aqueles utilizados para ajuste de $\mathrm{pH}$, como exemplo suspensão de cal. A realização de précloração também altera as características dos resíduos.

c) Tecnologia de tratamento e mecanismo de coagulação

A tecnologia de tratamento empregada produz resíduos com características diferentes. O sistema de filtração direta requer menor quantidade de coagulante, pois a coagulação é realizada no mecanismo de adsorção-neutralização de cargas, não havendo necessidade de produção de flocos para posterior sedimentação. No caso de filtração direta tem-se a retenção de partículas primárias ou de pequenos flocos destas, enquanto na filtração de água decantada tem-se a retenção, principalmente fragmentos de flocos. Evidentemente, o comportamento da filtração é diferente, assim como resultam diferentes as características do resíduo líquido gerado nas lavagens dos filtros. Assim sendo, as ETAs com ciclo completo possuem unidades de mistura rápida, floculação, decantação ou flotação e filtração, enquanto as de filtração direta possuem, em geral, unidades de mistura rápida e de filtração.

O tipo de decantador e o sistema de remoção dos resíduos, alteram significativamente as características dos resíduos, sendo que em decantadores convencionais estes permanecem por maior espaço de tempo, 30 a 60 dias, podendo levar a condições anaeróbias, responsáveis pela deterioração da qualidade do mesmo. $\mathrm{O}$ armazenamento prolongado também pode resultar no 
aumento de sua resistência à desidratação, segundo CORNWELL \& KOPPERS (1990). Estes resíduos em geral apresentam maiores concentrações de sólidos comparados aos produzidos nos decantadores de alta taxa, onde são efetuadas descargas diárias.

d) Contaminantes contidos nos produtos químicos utilizados no tratamento

Diversos são os contaminantes que podem existir nos produtos químicos utilizados no tratamento, como por exemplo, metais pesados no coagulante e na cal, alterando assim as características dos resíduos.

O sulfato de alumínio contém 3 a 6\% de ácido sulfúrico não reagido, bem como metais pesados oriundos da matéria prima utilizada na produção do sulfato, que é a bauxita. Este minério contém chumbo, cromo, cádmio, mercúrio e outros metais em sua constituição. Estes materiais farão parte dos resíduos.

CARVALHO (1999) diz que os produtos químicos utilizados nas ETAs, geralmente, contêm quantidades significativas de metais pesados e são responsáveis por 20 a $92 \%$ dos sólidos contidos nos despejos, podendo exercer grande influência nas características dos resíduos, bem como na qualidade da água tratada.

Para a caracterização dos resíduos torna-se necessário a determinação de parâmetros físico-químicos e biológicos, tais como sólidos, pH, DQO, DBO, metais pesados, fósforo total, nitrogênio total Kjeldahl (NTK), coliformes totais e Ercherichia coli, dentre outros. E recomendado que sejam realizados ensaios para determinação de parâmetros ditos não rotineiros: contagem de ovos de helmintos, microscopia óptica, difração de raios-X, microscopia de varredura, viscosidade, densidade, sedimentabilidade e resistência específica.

\subsubsection{Características Físicas}

Os parâmetros que englobam a caracterização física são concentração de sólidos, turbidez, cor, resistência específica, sedimentabilidade, tamanho e distribuição de partículas, densidade e viscosidade.

CORNWELL et al. (1987) dividiram as características físicas dos resíduos em macropropriedades e micropropriedades. Compõem as macropropriedades 
parâmetros tais como resistência específica, sedimentabilidade, compressibilidade e concentração de sólidos e, as micropropriedades são formadas por tamanho e distribuição de partículas, viscosidade e densidade. Os testes definidos como macropropriedades podem ser usados para auxiliar na seleção do método de desidratação e determinar as dosagens ótimas de condicionantes químicos, enquanto as micropropriedades na seleção do processo utilizado para desidratação.

Alguns valores de sólidos e turbidez, obtidos por pesquisadores brasileiros para resíduos gerados da descarga de decantadores em ETAs distintas, encontram-se inseridos na tabela 3.1.

Na tabela 3.2 estão os teores de sólidos e valores de turbidez encontrados por alguns pesquisadores brasileiros, também na década de 90, para resíduos gerados na lavagem de filtros de diferentes ETAs.

Tabela 3.1 - Parâmetros físicos determinados por pesquisadores brasileiros para resíduos provenientes da descarga de decantadores.

\begin{tabular}{|c|c|c|c|c|c|c|}
\hline $\begin{array}{c}\mathrm{ST} \\
(\mathrm{mg} / \mathrm{L}\end{array}$ & $\begin{array}{c}\mathrm{SV} \\
(\mathrm{mg} / \mathrm{L})\end{array}$ & $\begin{array}{c}\text { SST } \\
(\mathrm{mg} / \mathrm{L})\end{array}$ & $\begin{array}{c}\text { SSV } \\
(\mathrm{mg} / \mathrm{L})\end{array}$ & $\begin{array}{c}\text { Sól. Sed. } \\
(\mathrm{ml} / \mathrm{L})\end{array}$ & $\begin{array}{c}\text { Turbidez } \\
\text { (UT) }\end{array}$ & $\begin{array}{l}\begin{array}{l}\text { Fonte } \\
\text { (ano) }\end{array} \\
\end{array}$ \\
\hline 22928 & 3016 & 20813 & 2066 & 870 & 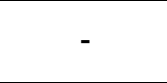 & $\begin{array}{c}\text { LEME \& MERL } \\
(2001)^{(a)}\end{array}$ \\
\hline $1700-4750$ & $300-793$ & $1500-4500$ & - & $550-800$ & $676-3077$ & $\begin{array}{l}\text { CARVALHO } \\
(1999)^{(a)}\end{array}$ \\
\hline 6112 & 1162 & 5590 & 940 & - & - & $\begin{array}{l}\text { PATRIZZI } \\
(1998)^{(b)}\end{array}$ \\
\hline 6281 & 102 & 5788 & 103 & 186 & - & $\begin{array}{l}\text { PATRIZZI } \\
(1998)^{(b)}\end{array}$ \\
\hline $14900-60794$ & - & $18530-46100$ & - & - & - & $\begin{array}{l}\text { CASTRO } \\
(1997)^{(b)}\end{array}$ \\
\hline 30275 & 7951 & 27891 & - & 710 & 3800 & $\begin{array}{l}\text { CORDEIRO } \\
{(11993)^{(b)}}^{\text {CORO }}\end{array}$ \\
\hline - & - & - & - & - & 4800 & $\begin{array}{l}\text { GRANDIN } \\
(1992)^{(b)}\end{array}$ \\
\hline 6300 & 441 & - & - & - & - & $\begin{array}{l}\text { CETESB } \\
(1990)^{(b)}\end{array}$ \\
\hline 21933 & 3290 & - & - & - & - & $\begin{array}{l}\text { CETESB } \\
(1990)^{(b)}\end{array}$ \\
\hline
\end{tabular}

(a) - ETA que utiliza cloreto férrico como coagulante primário.

(b) - ETA que utiliza sulfato de alumínio como coagulante primário. 
Tabela 3.2 - Parâmetros físicos determinados por pesquisadores brasileiros, na década de 90, para resíduos gerados nas lavagens de filtros.

\begin{tabular}{|c|c|c|c|c|c|c|}
\hline $\begin{array}{c}\mathrm{ST} \\
(\mathrm{mg} / \mathrm{L}\end{array}$ & $\begin{array}{c}\mathrm{SV} \\
(\mathrm{mg} / \mathrm{L})\end{array}$ & $\begin{array}{c}\text { SST } \\
(\mathrm{mg} / \mathrm{L})\end{array}$ & $\begin{array}{c}\text { SSV } \\
(\mathrm{mg} / \mathrm{L})\end{array}$ & $\begin{array}{c}\text { Sól. Sed. } \\
(\mathrm{ml} / \mathrm{L})\end{array}$ & $\begin{array}{c}\text { Turbidez } \\
\text { (UT) }\end{array}$ & $\begin{array}{l}\begin{array}{l}\text { Fonte } \\
\text { (ano) }\end{array} \\
\end{array}$ \\
\hline - & - & 100 & 33 & - & 90 & $\begin{array}{c}\text { ESCOBAR } \\
(2001)^{(b)}\end{array}$ \\
\hline 130 & - & 95 & - & 8 & 76 & $\begin{array}{c}\text { DI BERNARDO et } \\
{\text { al. }(1999)^{(b)}}^{\left(b^{2}\right.}\end{array}$ \\
\hline 507 & 75 & 491 & - & 70 & 288 & $\begin{array}{l}\text { CARVALHO } \\
(1999)^{(a)} \\
\end{array}$ \\
\hline $367-710$ & $210-360$ & 210-395 & 37-85 & $15-90$ & $120-240$ & $\begin{array}{l}\text { SOUZA FILHO } \\
\text { (1998) }^{(a)}\end{array}$ \\
\hline 88-110 & $18-52$ & 56-79 & $13-22$ & $2,4-5,0$ & $58-60$ & $\begin{array}{l}\text { SCALIZE } \\
(1997)^{(b)}\end{array}$ \\
\hline $438-668$ & - & $288-532$ & - & - & - & $\begin{array}{l}\text { CASTRO et al. } \\
(1997)^{(b)}\end{array}$ \\
\hline - & - & - & - & - & 615 & $\begin{array}{l}\text { SARON et al. } \\
(1997)^{(b)}\end{array}$ \\
\hline - & - & - & - & - & 30 & $\begin{array}{l}\text { GRANDIN } \\
(1992)^{(b)}\end{array}$ \\
\hline
\end{tabular}

- ETA que utiliza cloreto férrico como coagulante primário.

(b) - ETA que utiliza sulfato de alumínio como coagulante primário.

\subsubsection{Tamanho e Distribuição de Partículas}

Estes parâmetros são de fundamental importância para os estudos de redução do volume através da remoção de água e para verificar a influência que tal parâmetro pode fornecer na definição dos equipamentos e sistemas a serem utilizados. Os resíduos gerados em ETAs são compostos por partículas de diferentes tamanhos, sendo determinado pela natureza das partículas presentes na água bruta, da eficiência da coagulação, floculação e sedimentação, além do mecanismo utilizado para remoção dos resíduos.

A determinação do tamanho e a distribuição de partículas podem ser realizadas através de métodos como observações microscópicas e de fracionamento. O método de fracionamento de Karr, que utiliza vários meios filtrantes, permite determinar sólidos filtrados e retidos, possibilitando uma determinação aproximada da distribuição de partículas. Segundo CORDEIRO (1993), estes métodos apresentam grande margem de erro.

Equipamentos mais sofisticados, hoje disponíveis, como o SEDIGRAPH 5000 D, permitem uma melhor determinação no tamanho e distribuição das partículas, apresentando resultados mais precisos. 
CORDEIRO (1993), estudando o resíduo líquido proveniente da limpeza do decantador, em uma ETA que utiliza sulfato de alumínio como coagulante primário, determinou o tamanho e distribuição das partículas através do Sedighraf, mostrando que mais de $60 \%$ é menor que $20 \mu \mathrm{m}$.

SCALIZE \& DI BERANRDO (2000), determinaram o tamanho e distribuição das partículas através do Sedighraf, de material sedimentado resultante de ensaios de clarificação, com utilização de polímero aniônico, da água de lavagem de filtro, de uma ETA que utiliza sulfato de alumínio como coagulante primário, encontrando partículas com tamanho entre 0,3 e 15,0 $\mu \mathrm{m}$, relatam ainda que a medida que o teor de SST aumentava no sedimento o tamanho das partículas diminuía.

\subsubsection{Sedimentabilidade}

Com o objetivo de separar os sólidos de um meio líquido, sob ação de forças gravitacionais, o fenômeno da sedimentação é utilizado em:

a) Tratamento de água

- caixa de areia em sistemas de captação

- decantadores em ETAs

b) Tratamento de esgoto

- caixas de areia

- decantadores primários

- decantadores secundários

Sabe-se que em um meio líquido, partículas com características distintas apresentam comportamento diferenciado durante a sedimentação. Assim, determinadas partículas sedimentam com velocidade constante, enquanto outras modificam sua forma, peso e volume, durante sua permanência na unidade, variando suas características durante a sedimentação. Outras, sedimentam de maneira a formar uma zona de sedimentação. As partículas possíveis de serem separadas por sedimentação são classificadas em discretas e floculentas.

As partículas discretas, retidas principalmente nas caixas de areia, são aquelas que durante a sedimentação não alteram seu tamanho, forma ou peso e sua velocidade final de sedimentação é constante. 
As partículas floculentas são constituídas, principalmente, de matéria orgânica, flocos formados por coagulantes químicos e de microrganismos que tendem a se aglutinar, formando aglomerados de diferentes tamanhos, forma ou peso. Estes apresentam, normalmente, velocidade de sedimentação maior que a das partículas que os forma, e ao sedimentarem chocam-se com outras, aumentando seu peso e, conseqüentemente, a velocidade de sedimentação.

Admite-se, geralmente, que quanto melhor o lodo sedimenta e compacta, melhores serão suas características de desidratação. Devido a baixa taxa de sedimentação de lodos não condicionados, a aplicação do teste de sedimentação é praticamente limitada à determinação dos agentes condicionantes mais efetivos e sua dosagem ótima para melhorar a taxa de sedimentação e/ou taxa de filtração, GRANDIN (1992).

NOVAK \& CALKINS (1975), mostraram que a concentração de sólidos obtida no ensaio de sedimentação pode ser usada para prever os teores de sólidos na torta alcançados por vários outros métodos de desidratação como lagoas, centrifugação, filtração e drenagem.

No ensaio de sedimentação, que pode ser realizado utilizando-se coluna de sedimentação, instantes após o início do ensaio, a interface começa a se deslocar no sentido descendente e sua altura é anotada em intervalos de tempo pré-fixados, lançando-se em gráfico o valor da altura da interface contra o tempo. Completado o ensaio, traça-se a curva de deslocamento da interface que apresenta aspecto semelhante ao da curva da figura 3.1.

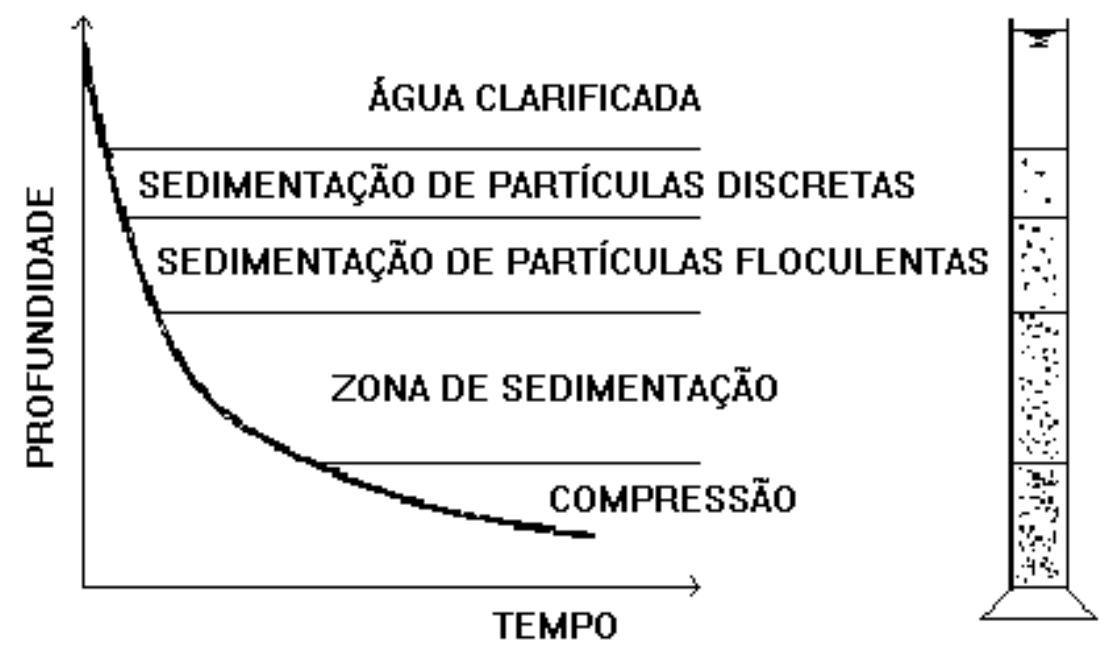

Figura 3.1 - Esquema de coluna de sedimentação.

Fonte: METCALF \& EDDY (1991). 


\subsubsection{Resistência Específica à Filtração}

Segundo CHRISTENSEN (1983), resistência específica é um parâmetro utilizado para descrever a filtrabilidade de lodos de águas residuárias e de outros resíduos. Tal parâmetro possibilita a escolha apropriada de polímeros e a seleção de dispositivos para desaguamento. CHRISTENSEN et al. (1985), afirmam que os lodos adensados apresentam valores de resistência específica à filtração entre $1 \mathrm{x}$ $10^{12}$ e $10 \times 10^{12} \mathrm{~m} / \mathrm{kg}$, sendo que quando devidamente condicionados com polímeros, estes valores são reduzidos para $1 \times 10^{10}$ e $1 \times 10^{11} \mathrm{~m} / \mathrm{kg}$. Os autores ainda sugerem o valor $1 \times 10^{11} \mathrm{~m} / \mathrm{kg}$ como limite para que se obtenha economia no desaguamento máximo realizado por dispositivos mecanizados.

ASCE \& AWWA (1996) dizem que resíduos com resistência específica superior a $1 \times 10^{12} \mathrm{~m} / \mathrm{kg}$ são considerados de difícil desidratação, e inferior a $1 \mathrm{x}$ $10^{12} \mathrm{~m} / \mathrm{kg}$ são considerados de fácil desidratação. GRANDIN (1992) afirma que resíduos com resistência específica menor que $1 \times 10^{12} \mathrm{~m} / \mathrm{kg}$ são de fácil desidratação, e superior a $5 \times 10^{12} \mathrm{~m} / \mathrm{kg}$ de difícil desidratação. A resistência específica aumenta proporcionalmente ao $\mathrm{pH}$ e inversamente à turbidez da água bruta (CORNWELL et al., 1987).

O menor valor de resistência específica obtido por GRANDIN (1992), utilizando polímeros sintéticos para condicionar água de lavagem de filtro, foi de $0,83 \times 10^{12} \mathrm{~m} / \mathrm{kg}$ utilizando lodo fesco com aplicação de $2 \mathrm{~g}$ de polímero/kgSST. Lodos adensados sem condicionamento químico, provenientes de ETAs que utilizam sulfato de alumínio como coagulante primário, apresentaram valores de resistência específica superiores a $5 \times 10^{12} \mathrm{~m} / \mathrm{kg}$, sendo considerados, portanto, de difícil desaguamento. Segundo o autor, a resistência específica de lodos adensados provenientes da água de lavagem de filtros varia de 6 a $12 \times 10^{12} \mathrm{~m} / \mathrm{kg}$ sem uso de polieletrólito, e da ordem de $1,5 \times 10^{12} \mathrm{~m} / \mathrm{kg}$ quando se emprega polieletrólito.

Segundo dados da SEREC (1987), para lodos gerados quando é usado o sulfato de alumínio como coagulante, a resistência específica varia de 5 a $50 \mathrm{x}$ $10^{12} \mathrm{~m} / \mathrm{kg}$. Testes realizados com o lodo gerado na ETA de Serra Azul-MG, usando cloreto férrico como œagulante, produziram valores de resistência específica da ordem de $10 \times 10^{12} \mathrm{~m} / \mathrm{kg}$.

$\mathrm{Na}$ tabela 3.3 estão contidos alguns valores típicos da resistência específica para diferentes tipos de lodos de ETEs. 
Tabela 3.3 - Valores típicos da resistência específica para diferentes tipos de lodo de ETEs.

\begin{tabular}{cc}
\hline Tipo de lodo & Resistência Específica a $49 \mathrm{KN} / \mathrm{m}^{3}(\mathrm{~m} / \mathrm{kg})$ \\
\hline Lodo bruto e primário & $10^{13}-10^{14}$ \\
Lodo ativado & $10^{12}-10^{14}$ \\
Lodo digerido anaerobiamente & $10^{12}-10^{13}$ \\
Lodo digerido por via aeróbia & $10^{11}-10^{12}$ \\
\hline
\end{tabular}

Fonte: ANDREOLI et al (2001a).

Lodos provenientes de digestor anaeróbio, segundo ALMEIDA et al. (1991b), utilizando sulfato ferroso e cal como condicionantes, forneceram valores de resistência específica entre $0,02 \times 10^{12}$ e $0,15 \times 10^{12} \mathrm{~m} / \mathrm{kg}$. Ainda utilizando o mesmo lodo com cloreto férrico e cal como condicionantes foram obtidos valores de 0,01 a $0,19 \times 10^{12} \mathrm{~m} / \mathrm{kg}$

Observa-se na literatura que, dependendo da origem do lodo, a resistência específica pode variar de 0,1 a $12 \times 10^{12} \mathrm{~m} / \mathrm{kg}$, tornando-se imperiosa a execução de ensaios visando a escolha apropriada do método de desaguamento e o uso de condicionante químico em ETA.

SCALIZE (1997) utilizando polímero aniônico para clarificação, por sedimentação, da água de lavagem de filtros, relatou valores de resistência específica da ordem de $3,0 \times 10^{12} \mathrm{~m} / \mathrm{kg}$ para sedimento proveniente da água de lavagem filtro que utiliza sulfato de alumínio como coagulante primário e, SOUZA FILHO (1998), utilizando o mesmo polímero, encontrou valores da ordem de 10,0 $\mathrm{x} 10^{12} \mathrm{~m} / \mathrm{kg}$, para sedimento proveniente de água de lavagem de filtro que utiliza cloreto férrico como coagulante primário.

DI BERNARDO et al. (1999), estudando a água de lavagem de filtro de uma ETA que possui filtração direta ascendente com descargas de fundo intermediárias obtiveram valores de resistência específica da ordem de $30,0 \times 10^{12} \mathrm{~m} / \mathrm{kg}$, no sedimento proveniente do ensaio sem uso de polímero para clarificação, e quando empregado polímero aniônico valores da ordem de 5,0 x 10 $12 \mathrm{~m} / \mathrm{kg}$, mostrando uma maior eficiência quando utilizado polímero como condicionante.

A resistência específica é definida como a maior ou menor resistência à passagem de um líquido através de uma massa sólida, podendo ser determinada por meio da eq.(3.1) ALMEIDA et al. (1991a e b). 
$r=\frac{2 \cdot b \cdot P \cdot A^{2}}{\mu \cdot C}$

em que:

$r=$ resistência específica $(\mathrm{cm} / \mathrm{g})$;

$P=$ pressão de filtração $\left(\mathrm{g} / \mathrm{cm} \cdot \mathrm{s}^{2}\right)$. Pressão utilizada $=500 \mathrm{~g} / \mathrm{cm} \cdot \mathrm{s}^{2}$;

$A=$ área filtrante $\left(\mathrm{cm}^{2}\right)$;

$\mu=$ viscosidade do filtrado $(\mathrm{g} / \mathrm{cm} . \mathrm{s})$;

$\mathrm{C}=$ massa de sólidos suspensos por unidade de volume filtrado $\left(\mathrm{g} / \mathrm{cm}^{3}\right)$;

$b=$ coeficiente $\left(\mathrm{s} / \mathrm{cm}^{6}\right)$, dado pela eq (3.2) ALMEIDA et al. (1991a e b).

$b=\frac{d(t / v)}{d v}$

em que:

$\mathrm{t}=$ tempo de filtração (s);

$\mathrm{v}=$ volume filtrado $\left(\mathrm{cm}^{3}\right)$.

O valor do coeficiente $\mathbf{b}$ é obtido construindo-se um gráfico no qual se tem os valores de $\mathbf{v}$ e (t/v), conforme mostrado na FIGURA 3.2.

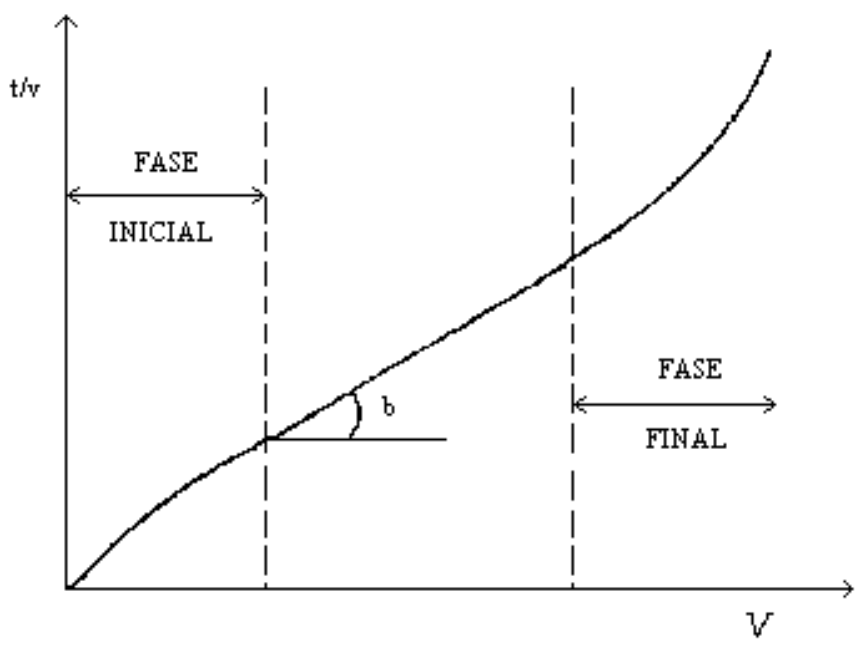

Figura 3.2 - Gráfico típico da relação t/v em função de v, para obtenção de b no cálculo da resistência específica.

Fonte: ALMEIDA et al. (1991a). 


\subsubsection{Características Biológicas}

As águas de abastecimento apresentam o risco de serem poluídas por águas residuárias e excretas de origem humana ou animal, podendo, desta forma, conter organismos patogênicos, tornando-se assim um veículo de transmissão de doenças. Por isso, impõe-se a necessidade de exames rotineiros das mesmas, para determinar seu grau de segurança do ponto de vista bacteriológico.

Embora existam métodos desenvolvidos para detecção de vários organismos patogênicos de veiculação hídrica, os mesmos não são aplicados rotineiramente devido ao alto custo e à necessidade de pessoal especializado. Além disso, uma vez que o lançamento de organismos patogênicos nos esgotos é intermitente e está na dependência das condições de saúde da população, é possível que, em determinadas ocasiões, não se detectem esses organismos na água, porém sua ausência não indica que a mesma seja segura.

O estudo das características das águas a serem reutilizadas ou dispostas é de suma importância, visando obtê-las com características conhecidas e aceitáveis. Como parte dos parâmetros utilizados na caracterização destas águas pode-se empregar a pesquisa parasitológica e de coliformes com a finalidade de evitar possíveis contaminações, pois inúmeras são as moléstias que podem ser contraídas através da ingestão de água e alimentos contaminados por vírus, coliformes, ovos e cistos, bem como pela penetração ativa de larvas filarióides através da pele ou mucosas.

\subsubsection{Parasitológico}

Além das doenças de origem virótica e bacteriana, várias parasitoses são provocadas pela presença de helmintos no corpo humano, tornando-se importante a pesquisa da presença destes parasitas nos resíduos.

SCALIZE (1997) relata que os protozoários são constituintes dos resíduos, e vêem despertando interesse, pois estão presentes nos sobrenadantes e sedimentos, obtidos após clarificação em coluna de sedimentação com ou sem a utilização de condicionante. Em seu trabalho o autor realizou apenas pesquisa qualitativa encontrando cisto de Entamoeba coli, larvas de Strongiloides stercoralis e Acylostomidae além de ovos de Hymenolepis nana e Acylostomidae. 
Visando melhorar este quadro, devem ser estudadas soluções racionais para estes problemas em cada ETA. O sistema de tratamento e disposição dos resíduos deve ser compatível com as condições do local, ressaltando-se a situação financeira, a localização, disponibilidade de área, quantidade de lodo produzido e qualidade da água bruta, dentre os fatores.

Nem todos helmintos apresentam interesse médico, sendo que os nematóides têm maior interesse por possuírem um período de latência no solo antes de atingirem o hospedeiro. Segundo CRISPIM (1994), a umidade e a matéria orgânica são condições favoráveis ao desenvolvimento e sobrevivência dos helmintos no meio ambiente.

Os principais nematodas compreendem os parasitas que não necessitam de hospedeiro intermediário, sendo exemplos o Ascaris lumbricoides, Trichuris trichiura, e os ancilostomídeos Ancylostoma duodenale e Necator americanus, além dos que necessitam apenas um hospedeiro intermediário como é o caso da Taenia saginata e Taenia solium.

\subsection{Ovos e Larvas de Helmintos}

A pesquisa de ovos e larvas bem como sua quantificação é de suma importância para verificar a eficiência do sistema após o tratamento. Desta forma é obtido um efluente com qualidade conhecida, podendo-se assim evitar possível contaminação ou distúrbios no sistema.

Muitos métodos para quantificação de ovos e larvas de helmintos são descritos na literatura, sendo que todos apresentam vantagens edesvantagens: alguns têm alta porcentagem de recuperação, mas são muito demorados, muitos não são suficientemente relatados com detalhes para sua reprodução ser possível, e sua taxa de recuperação é desconhecida; outros requerem produtos químicos caros e inadequados para uso em laboratório com equipamentos limitados, e outros recuperam somente limitadas quantidades de espécies. Não existe um método de uso universal que apresente total recuperação dos ovos de helmintos de importância médica. Todo método para avaliação é baseado em um ou dois fundamentos principais: através da flotação em solução com densidade relativamente alta, em óleo ou outro material, sendo separado na interface da solução (normalmente éter ou acetato etílico), ou através da sedimentação, onde o 
parasita permanece no fundo. Ambos métodos contam com a força centrífuga (AYRES \& MARA, 1996).

CRISPIN (1994), em seu trabalho objetivando selecionar os métodos para pesquisa de ovos de helmintos em águas residuais brutas e tratadas, satisfazendo a rapidez de execução; comodidade na observação microscópica; facilidade de aplicação tanto em amostras de esgoto bruto quanto em amostras de esgoto tratado; índice satisfatório de detecção de ovos nas amostras; baixo custo; possibilitar o diagnóstico segundo recomendações da OMS; concluiu que o método de Bailenger é um dos mais indicados, podendo ser aplicado à amostras residuais brutas e tratadas.

\subsubsection{Coliformes Totais e Escherichia coli}

Para a avaliação das condições sanitárias de uma água, utilizam-se bactérias do grupo coliformes, que atuam como indicadores de poluição fecal, pois estão sempre presentes no trato intestinal humano e de outros animais de sangue quente, sendo eliminados em grande número nas fezes. A presença de coliformes na água pode indicar poluição, com o risco potencial da presença de organismos patogênicos; sua ausência indica uma água bacteriologicamente potável, uma vez que são mais resistentes na água que a maioria das bactérias patogênicas de origem intestinal.

O NMP (número mais provável) é usado para a avaliação da eficiência de processos de tratamento de águas e águas residuárias domésticas ou industriais, avaliação e controle da qualidade de mananciais que abastecem estações de tratamento de água, avaliação e controle de qualidade bacteriológica de águas destinadas a consumo humano (sem ou com desinfecção ou após tratamento convencional) e avaliação e controle de águas destinadas segundo CETESB (1993):

a) à irrigação de hortaliças, plantas frutíferas, culturas arbóreas, cerealíferas e forrageiras;

b) à recreação de contato primário (natação, esqui aquático e mergulho);

c) à dessedentação de animais;

d) à criação natural ou intensiva (aqüicultura) de espécies destinadas à alimentação humana;

e) ao abastecimento industrial. 
CORDEIRO (1993), através de exame bacteriológico do resíduo líquido da limpeza dos decantadores de uma ETA que utiliza sulfato de alumínio como coagulante primário encontrou um número de coliformes totais de $2,4 \times 10^{5}$ NMP/100mL. DI BERNARDO et al. (1999b), analisando o resíduo líquido da descarga de um decantador de alta taxa com descarga diária, de uma ETA que utiliza cloreto férrico como coagulante primário, encontrou um número de coliformes totais de $1,12 \times 10^{5} \mathrm{NMP} / 100 \mathrm{~mL}$ e Ercherichia coli de 1,66 x 10 ${ }^{4} \mathrm{NMP} / 100 \mathrm{~mL}$.

$\mathrm{Na}$ TABELA 3.3 são apresentados alguns resultados de exames bacteriológicos realizados em resíduo líquido proveniente da lavagem de filtros, em diferentes ETAs.

Tabela 3.4 - Resultados de exames bacteriológicos realizados no resíduo líquido proveniente da lavagem de filtros de diferentes ETAs, segundo alguns autores.

\begin{tabular}{|l|c|c|c|c|c|}
\hline $\begin{array}{c}\text { PARÂMETRO } \\
(\mathrm{NMP} / 100 \mathrm{~mL})\end{array}$ & $\begin{array}{c}\text { SCALIZE } \\
(1997)^{1}\end{array}$ & $\begin{array}{c}\text { SOUZA FILHO } \\
(1998)^{2}\end{array}$ & $\begin{array}{c}\text { DI BERNARDO } \\
\text { et al. }(1999)^{1}\end{array}$ & $\begin{array}{c}\text { DI BERNARDO } \\
\text { et al. }(1999 \mathrm{a})^{1}\end{array}$ & $\begin{array}{c}\text { DI BERNARDO } \\
\text { et al. }(1999 \mathrm{~b})^{2}\end{array}$ \\
\hline Coliformes totais & $1640-3440$ & $11100-241920$ & 1095 & 17329 & 19350 \\
\hline Escherichia coli & 68 a 453 & $100-17820$ & 3 & 20 & 200 \\
\hline
\end{tabular}

1 - ETA que utiliza sulfato de alumínio; 2 - ETA que utiliza cloreto férrico

\subsubsection{Características Químicas}

Os constituintes presentes nos resíduos de ETAs tem relevante importância, pois os padrões de disposição final tem tornado-se mais rígidos.

As características químicas como concentração de metais pesados, $\mathrm{pH}$, demanda biológica de oxigênio, demanda química de oxigênio, nitrogênio, fósforo e difração de raios-X são parâmetros que afetam mais as opções de disposição e reuso do que nos processos de manuseio, adensamento e desidratação do material produzido.

\subsubsection{Metais Pesados}

São considerados metais pesados aqueles que apresentam densidade superior a $5 \mathrm{~g} / \mathrm{cm}^{3}$.

A determinação de metais pesados é de grande importância para os estudos dos impactos na disposição dos resíduos de ETAs e ETEs em aterros sanitários ou na agricultura. Os metais pesados têm efeitos inibitórios nos processos biológicos 
presentes na ETE, e na deterioração da qualidade do efluente final gerado pela ETE e no reaproveitamento dos resíduos gerados pela ETA.

Segundo FERREIRA et al (1999), os metais pesados presentes no lodo de ETEs podem ter origem de rejeitos domésticos, águas pluviais e efluentes industriais. Para utilização deste lodo na agricultura os metais que oferecem maior perigo são o $\mathrm{Cd}, \mathrm{Cu}$, Mo, Ni e o Zn.

Abaixo estão alguns metais e seus significados sanitários.

- Cádmio. É um dos elementos que mais oferece riscos potenciais para a saúde humana, pois se acumula em organismos aquáticos, possibilitando sua entrada na cadeia alimentar. Pode ser fator para vários processos patológicos no homem, incluindo disfunção renal, hipertensão, aterosclerose, inibição no crescimento, doenças crônicas em idosos e câncer. É um metal de grande interesse relacionado à aplicação agrícola do lodo de ETEs, sendo desnecessário ao metabolismo vegetal e animal.

- Cobre. É um elemento usualmente encontrado em combinação com proteínas do organismo humano e tem papel na formação dos eritrócitos, na liberação de ferro no tecido e desenvolvimento de vários tecidos do corpo. No homem, a ingestão de doses excessivamente altas pode acarretar irritação e corrosão da mucosa, danos capilares generalizados,problemas hepáticos e renais e irritação do sistema nervoso central seguido de depressão. Entretanto, a intoxicação por cobre é muito rara.

- Níquel. Doses elevadas deste metal podem causar dermatites nos indivíduos mais sensíveis e afetar nervos cardíacos e respiratórios. A maior contribuição para o meio ambiente, pela atividade humana, é a queima de combustíveis fósseis. No solo, o teor de níquel é muito variável dependendo de fatores como a rocha de origem.

- Zinco. Este metal, por ser um elemento essencial para o ser humano, só se torna prejudicial à saúde quando ingerido em concentrações muito altas, o que é extremamente raro. É um elemento essencial às plantas e animais e do qual muitos solos brasileiros são carentes. As doses tóxicas são elevadas dependendo do $\mathrm{pH}$ do solo.

- Molibdênio. Não é considerado com um elemento tóxico aos humanos, entretanto, elevadas doses podem resultar em toxicidade crônica. O lodo de 
esgotos contém baixos níveis deste metal e provavelmente não é a causa de molibdenose em animais, exceto quando são aplicadas altas doses no solo através do lodo.

\subsection{MÉTODOS DE TRATAMENTO E DISPOSIÇÃO DOS RESÍDUOS}

Apesar de existirem vários métodos para tratamento e disposição dos resíduos gerados em ETAs, é extremamente importante encontrar métodos alternativos, visando proteção do meio ambiente e menores custos envolvidos nos processos e operações. O método para tratamento e disposição dos resíduos deve ser escolhido verificando alternativas e soluções visando aspectos como quantidade e características dos resíduos; disponibilidade de área; características dos mananciais próximos às ETAs; custos envolvidos nas possíveis soluções, dentre outros. O resultado obtido para um determinado resíduo não deve ser aplicado em outro, pois variam muito em ETAs diferentes.

Os resíduos apresentam grande quantidade de água que pode ser retirada antes da disposição final do lodo. Apesar de não existir técnicas capazes de caracterizar os tipos de água existentes nos resíduos, muitos esforços têm sido direcionados por diversos pesquisadores. A classificação das águas presentes nos resíduos e nos lodos pode ser como água livre; água inter-flocos; água adsorvida nos flocos; água inter partículas; água adsorvida nas partículas e água de partículas.

Existem vários métodos com a finalidade de retirar as águas desses resíduos e lodos, para diminuir o volume a ser disposto, reutilizando ou não a parte líquida.

\subsubsection{Equalização dos Resíduos}

A equalização dos resíduos gerados em ETAs é essencial para obter um resíduo homogêneo, podendo ser controlado sua vazão antes de seu tratamento ou ainda sua disposição, podendo ser na rede coletora de esgoto. Os resíduos gerados durante a lavagem de um filtro ou descarga de decantador apresentam diferentes concentrações de sólidos e demais constituintes, sendo mais concentrados na porção inicial. Este fato pode ser observado na figura 3.3, onde é 
apresentada uma curva com os valores de turbidez e SST em função do tempo de lavagem, obtida durante a lavagem de um filtro de uma ETA que utiliza sulfato de alumínio como coagulante primário.

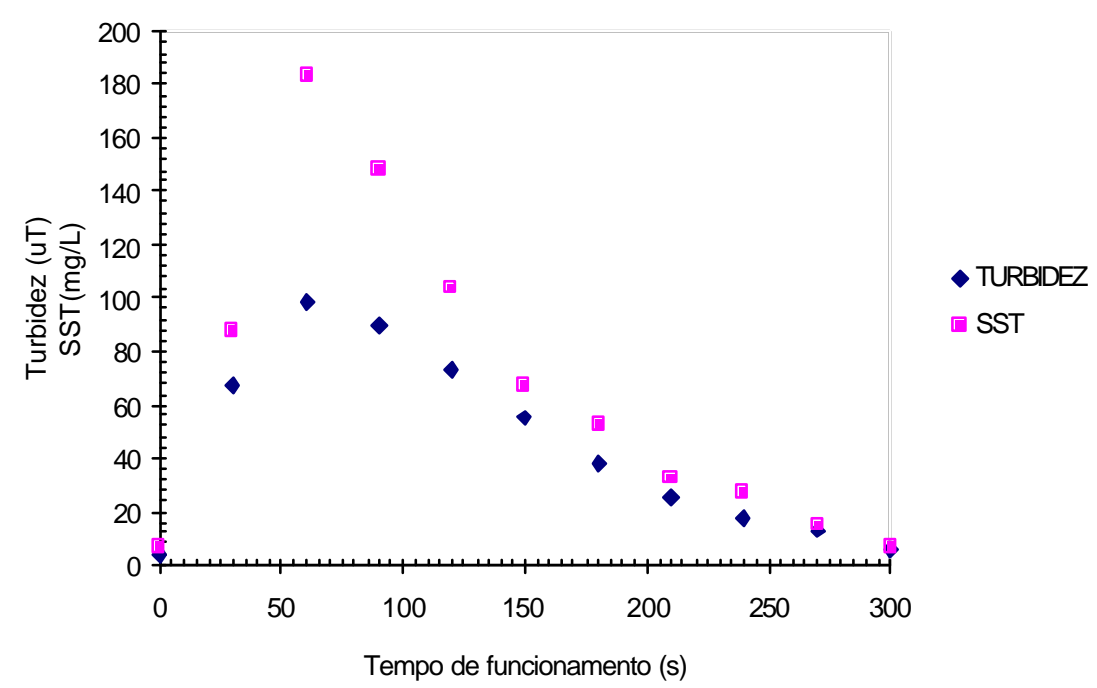

Figura 3.3 - Variação de turbidez e de concentração de SST durante a lavagem do filtro de uma ETA que utiliza sulfato de alumínio como coagulante primário.

Fonte: SCALIZE (1997).

CORNWELL et al. (1987) recomendam que, para evitar disposição de sólidos na rede coletora de esgotos, o lançamento dos resíduos seja realizado durante os períodos do dia em que o escoamento na tubulação seja suficiente para manter uma velocidade mínima de $0,8 \mathrm{~m} / \mathrm{s}$.

CARVALHO (1999), sugere que os resíduos sejam lançados nos períodos em que a vazão afluente à ETE seja baixa, por exemplo, da meia-noite às seis horas da manhã, coincidindo com às necessidades da ETA, pois é neste período, em virtude da pouca necessidade de água para o abastecimento, que se torna mais propício para limpeza dos filtros e decantadores. Não pode ser esquecido de verificar se a ETE, apresentando uma vazão afluente baixa de esgoto, suporta os resíduos de uma ETA, visto que seus constituintes poderão interferir no desempenho da ETE.

$\mathrm{Na}$ minha opinião a disposição dos resíduos de ETA em uma ETE deverá ser realizada durante o dia, onde ocorrerá diluição deste resíduo com o esgoto sanitário, atenuando o impacto na ETE.

Segundo CARVALHO (2000), os resíduos de ETA, provavelmente, só poderão ser lançados em uma rede coletora de esgotos provida de tratamento, 
após sua equalização prévia, visto que a maior parte dos sólidos contidos nos decantadores e filtros é eliminada na forma de pulsos.

\subsubsection{Condicionamento e Adensamento dos Resíduos}

Geralmente o condicionamento dos resíduos e adensamento do lodo é realizado antes da desidratação mecânica, podendo anteceder outros processos. $O$ condicionamento se faz importante devido a baixa concentração de sólidos apresentado por estes resíduos. De forma geral o condicionamento atua sobre características como tamanho e distribuição do tamanho de partículas, carga superficial e grau de hidratação das partículas.

O condicionamento pode ser químico ou físico, dependendo das características dos resíduos e do local onde é produzido.

O condicionamento químico geralmente é realizado através da adição de polímeros, naturais ou artificiais e, dependendo das características dos resíduos, principalmente $\mathrm{pH}$, poderão ser utilizados polímeros classificados quanto aos grupos ionizáveis que apresentam, como catiônicos, aniônicos ou não iônicos. Os polímeros catiônicos funcionam melhor com valores de $\mathrm{pH}$ abaixo de 7,0, e os não iônicos com valores entre 6,5 e 8,5, sendo que para pH acima de 8,5 os aniônicos são os mais indicados. MURRAY et al. (1994), dizem que a adição de polímeros fortalece os flocos, formados pela mistura do coagulante com a matéria particulada presente na água bruta, unindo-se com ligações mais fortes, de forma que os mesmos podem ser submetidos a forças de cisalhamento sem romper suas ligações.

SOUZA FILHO (1998) e SCALIZE (1997), em estudos realizados com água de lavagem de filtro, promoveram um condicionamento com polímero aniônico, antes do adensamento por gravidade, o primeiro autor utilizando resíduo de uma ETA que utilizava cloreto férrico como coagulante primário, obteve, para uma melhor clarificação e adensamento do lodo uma relação de $10 \mathrm{~g}$ de polímero por kg de SST seco presentes no resíduo. O segundo autor empregando o mesmo polímero no condicionamento da água de lavagem de filtro de uma ETA que utiliza sulfato de alumínio como coagulante primário, encontrou uma relação de $24 \mathrm{~g}$ de polímero por kg de SST seco. 
FERREIRA FILHO (1997), realizando pré-condicionamento de resíduos de ETA visando adensamento por gravidade, revelou como sendo mais adequado os polímeros não iônico e catiônico para um determinado resíduo, e os polímeros não iônico e aniônico para resíduo de outra ETA, indicando que para cada resíduo deverão ser realizados ensaios visando obter o melhor polímero.

O condicionamento físico pode ser realizado através do congelamentodegelo, sendo mais empregado em países de clima frio. O congelamento produz mudanças físicas no lodo, removendo a água e, destruindo sua estrutura coloidal, sendo a consistência gelatinosa reduzida e as partículas sólidas tomam formas similares a grãos de areia, que quando aquecidos sedimentam facilmente. Métodos de desidratação de baixo custo, precedidos de condicionamento por congelamento, podem resultar em grau de desidratação entre 30 e 50\%.

Outros métodos conhecidos para o condicionamento são: Térmico, Peróxido de hidrogênio e auxiliares físicos de filtração.

Segundo FERREIRA FILHO (1997), o adensamento é uma das mais importantes operações unitárias do processo de tratamento da fase sólida pois, de um modo geral, os equipamentos de desidratação mecânica existentes no mercado recomendam uma concentração de ST no lodo de entrada da ordem de $2 \%$ para que o funcionamento ocorra de forma adequada.

O adensamento do lodo, precedendo a desidratação mecânica, é considerado essencial, sendo que os métodos mais comuns de adensamento tem sido por sedimentação ou flotação, ou adensamento mecanizados. Os adensadores por gravidade podem ser de fluxo contínuo ou de batelada, podendo gerar, segundo CORNWELL et al. (1987), uma concentração de sólidos final de 1 a 3\%. No processo por flotação o material obtido pode resultar sólidos com concentrações entre 2 e $4 \%$.

Segundo REALI (1991), a flotação pode ser definida como sendo um processo de separação de partículas sólidas ou líquidas de uma fase líquida através da utilização de bolhas de gás, normalmente o ar. Tais bolhas, aderindo à superfície das partículas, aumentam seu empuxo, provocando assim a ascensão das mesmas em direção à superfície da fase líquida, onde podem ser coletadas.

A técnica da flotação pode ser dividida em flotação por ar disperso, por ar dissolvido e eletrolítica. Segundo PATRIZZI (1998), flotação por ar dissolvido é a modalidade de flotação mais utilizada na área de saneamento, onde são introduzidas no sistema microbolhas de ar, com diâmetro da ordem de milimicras, 
resultando um agregado com densidade suficientemente menor que a densidade do líquido para efeito de flotação.

Segundo CORNWELL \& KOPPERS ${ }^{1}$ apud PATRIZZI (1998), através de um lodo, originalmente com 0,1 a $0,2 \%$ de sólidos secos, obteve-se, após espessamento por flotação, utilizando polímero aniônico, uma concentração de sólidos secos entre 2,5 e 3,5\%.

PATRIZZI (1998) trabalhando com resíduo de ETA que utiliza sulfato de alumínio como coagulante primário, após obtenção das dosagens adequadas de polímero, entre 4,38 a 4,50 g/kg de SST, a flotação por ar dissolvido apresentou excelentes resultados utilizando-se polímero catiônico, aniônico e não iônico, atingindo teor de sólidos entre 6,7 a 7,1\%, sendo o teor de sólidos inicial entre 0,50 a $0,65 \%$.

ESCOBAR (2001) em estudos com clarificação de água de lavagem de filtro, proveniente da ETA do rio Descoberto - Brasília, que utiliza sulfato de alumínio como coagulante, observou o efeito favorável na adição de polímero na separação líquido-sólido em relação a remoção de turbidez, cor aparente, SST e coliformes. Os resultados mostram que a dosagem de polímero que forneceu os valores mais baixos em termos de turbidez foi de $3,0 \mathrm{~g}$ polímero aniônico/kg de SST, com velocidade de sedimentação de $1,0 \mathrm{~cm} / \mathrm{min}$.

\subsubsection{Desidratação}

Os processos de desidratação, utilizados para lodos de ETAs, têm por finalidade reduzir o percentual de água do lodo a fim de minimizar o volume a ser disposto. A desidratação pode ser realizada de forma natural ou mecânica.

\subsubsection{Desidratação Natural}

Na desidratação natural há remoção de água por evaporação natural, drenagem por gravidade ou induzida.

\footnotetext{
${ }^{1}$ CORNWELL, D.A.; KOPPERS, H.M.N. (1990). Slib, schlamm, sludge. Amercian Water Works Association, Research Foudation, KIWA. Research Foudation, Denver, p. 72 108.
} 
Tem como vantagens o fato de serem menos complexas, fáceis de operar, e necessitarem menor energia quando comparado aos mecânicos. Podem ser descritos como desvantagens o fato da necessidade de áreas maiores, dependência das condições climáticas e trabalho intensivo, difícil remoção de lodo, aspecto visual e deterioração da qualidade do sobrenadante.

Podem ser exemplos de desidratação natural as lagoas de lodo e os leitos de secagem.

Geralmente por razões econômicas e operacionais, as ETAs que geram baixo volume de lodo utilizam-se da desidratação natural. Na Holanda, a maioria das ETAs utilizam lagoas de lodo, segundo CORNWELL \& KOPPERS (1990).

\subsubsection{Desidratação Mecânica}

Este tipo de desidratação é mais indicado para ETAs que possuem pouca disponibilidade de área, que desejam elevada concentração de sólidos na torta e que o tratamento ocorra em curto período de tempo. São exemplos de processos de desidratação mecânica as centrífugas, filtros prensas e "Belt Press".

\subsection{Desidratação por Centrifugação de Lodo de ETA e ETE}

Com a finalidade de melhorar as características de compactação do lodo antes de sua desidratação através de centrífuga, é necessário efetuar um condicionante químico do lodo digerido, mediante a aplicação de produtos químicos, sendo comumente empregado polímero.

Segundo CASTRO et al. (1997-b), a utilização de centrífugas para a remoção de sólidos, após adensamento, em unidades de tratamento de resíduos de ETAs é uma das opções mais empregadas em todo o mundo. Em seu trabalho obteve lodo desidratado com $35 \%$ a $40 \%$ de sólidos secos, destinados à disposição final.

Segundo ALÉM SOBRINHO (2000), o teor de sólidos para lodos desidratados por centrífugas pode variar de 20 a 25\% para lodos digeridos aerobicamente e 25 a 30\% para lodos digeridos anaerobiamente. QASIM ${ }^{2}$ (1999)

${ }^{2}$ QASIM, S.R. (1999). Wastewater treatment plants: Planning Design and operation. $2^{\text {nd }}$ edition, Technonic Publishing company, Inc. 
apud TSUTIYA et al (2002), diz que o teor de sólidos do lodo de ETE adensado por centrífuga pode atingir valores entre 5 e $8 \%$.

ANDREOLI et al (2001a), relatam que centrífugas horizontais tipo "decantadoras" com velocidade entre 800 e 3200 rpm normalmente produzem tortas com teor de sólidos acima de $20 \%$ e centrifugado clarificado, e que o uso de polieletrólito está mais relacionado com a concentração de sólidos no líquido centrifugado do que com o teor de sólidos na torta.

Na tabela 3.5 podem ser observados os desempenhos típicos de centrífugas no desaguamento de lodos.

Tabela 3.5 - Desempenho típico de centrífugas no desaguamento de lodos

\begin{tabular}{lccc}
\hline \multicolumn{1}{c}{ Tipo de lodo } & $\begin{array}{c}\text { Concentração de } \\
\text { SST na torta }(\%)\end{array}$ & $\begin{array}{c}\text { Captura de sólidos } \\
(\%)\end{array}$ & $\begin{array}{c}\text { Dosagem de } \\
\text { polieletrólito }(\mathrm{g} / \mathrm{kg})\end{array}$ \\
\hline Lodo bruto primário & $28-34$ & 95 & $2-3$ \\
Lodo anaeróbio & $35-40$ & 95 & $2-3$ \\
Lodo ativado & $14-18$ & 95 & $6-10$ \\
Lodo misto bruto & $28-32$ & 95 & $6-10$ \\
Lodo misto anaeróbio & $26-30$ & 95 & $4-6$ \\
Lodo aeróbio $^{* *}$ & $18-22$ & 95 & $6-10$ \\
\hline
\end{tabular}

$\left(^{*}\right)$ lodo primário + lodo ativado excedente

$\left({ }^{* *}\right)$ aeração prolongada ou lodo ativado excedente

Fonte: GONÇALVES \& LUDUVICE (2000)

BARBOSA (1997), utilizando decanters centrífugas para desidratação de lodo de água de lavagem de filtro da ETA - Rio descoberto, Brasília - DF, adensado por sedimentação, obteve concentração de lodo desidratado superior a 30\%, atingindo concentrações de $35 \%$. Relata que o consumo de polímero aniônico de alta carga é de $2,0 \mathrm{~g} / \mathrm{kg}$ sólidos secos.

ANDREOLI et al (2001a), em teste de separação sólidos / líquido, utilizando um centrifuga de laboratório a $1000 \mathrm{~g}$ durante 2 minutos, sem a utilização de condicionante, obteve uma média da concentração de ST de $24 \%$ e o líquido clarificado conteve $800 \mathrm{mg} / \mathrm{L}$. Com condicionante obteve uma concentração média de ST de $27 \%$ e o líquido clarificado praticamente não apresentou ST. 
Segundo LERSCH et al. ${ }^{3}$ apud BARBOSA (1997), na ETA Belém Novo - RS, foram observadas vantagens das centrífugas em relação às prensas para desidratação de lodo de ETA, não só no custo inicial de aquisição, como também, simplicidade de instalação, menor manutenção e mão de obra para operação dos sistemas, e, de maneira marcante, no custo operacional dos equipamentos.

PATRIZZI (1998), utilizando lodos, espessados por flotação e por gravidade, provenientes de decantadores de estação de tratamento de água que utilizam sulfato de alumínio como coagulante primário, obteve, após centrifugação, os melhores resultados quando aplicado polímero catiônico na centrifugação na razão de $3,6 \mathrm{~g} / \mathrm{kg} \mathrm{SST}$, sendo que as amostras foram obtidas do espessamento por flotação utilizando 4,38 a $4,50 \mathrm{~g} / \mathrm{kg}$ SST e, do espessamento por gravidade utilizando 9,31 a 10,26 g/kg SST. A rotação empregada foi de $3000 \mathrm{rpm}$.

\subsubsection{Recirculação}

Esta técnica geralmente é feita, mais com o objetivo de recuperar a água de lavagem dos filtros do que propriamente um destino para o problema. Neste caso os resíduos estarão sendo concentrados nos decantadores. Em algumas ETAs as águas de lavagem dos filtros são recirculadas integralmente com todos os sólidos e constituintes presentes, em outros é feita uma prévia sedimentação, recirculando apenas o sobrenadante.

Recircular o resíduo líquido pode tornar potencial a ocorrência de distúrbios no tratamento do processo e afetar a qualidade final da água, CORNWELL \& LEE (1994). Os autores mostram ainda, como exemplos de constituintes indesejáveis, os cistos de Giardia sp, oocistos de Criptosporidium sp e, além de metais como ferro e manganês temos carbono orgânico total, precursores de trihalometanos, gosto e odor.

${ }^{3}$ LERSCH, E.C. et al. (1992). Relatório final da Comissão de lodos - DMAE, nov. 1992. 


\subsubsection{Recirculação Total do Resíduo}

Segundo FERREIRA FILHO (1997), as ETAs do Guaraú e Alto da Boa Vista, ambas responsáveis pelo abastecimento de água de parte da Região Metropolitana da Grande São Paulo, realizam com sucesso o reaproveitamento de $100 \%$ de suas água de lavagem de filtros.

SARON et al. (1997), relatam em seu trabalho que a ETA Guaraú produz $1,5 \%$ do total de água bruta em forma de água de lavagem de filtro, e a recirculação deste resíduo sem prévia sedimentação pode fornecer uma redução de até10\% na dosagem de sulfato de alumínio utilizado no tratamento. Diz ainda que na produção, em média, de $33,5 \mathrm{~m}^{3} / \mathrm{s}$ de água tratada a redução da adição de coagulante é de $1,0 \mathrm{mg} / \mathrm{L}$.

\subsubsection{Recirculação do Sobrenadante}

BARBOSA (1997), relata o aproveitamento da água de lavagem de filtro da ETA - Rio Descoberto, em Brasília - DF, após sua clarificação em adensadores e na desidratação do lodo adensado em decanters centrífugos, mostrando que o retorno do sobrenadante à ETA não compromete o seu desempenho.

\subsubsection{Disposição Final}

Pode ser considerado como disposição final o lançamento do resíduo líquido integralmente ou, após tratamento, podendo ser desidratação precedida por um condicionamento e adensamento, da parte clarificada e o lodo produzido.

MURRAY (1994), relata que, no passado, devido sua simplicidade, o lançamento nos cursos d'água ou em lagoas de lodo foram os métodos mais utilizados para disposição final dos resíduos de ETAs. Outros métodos alternativos, atualmente são existentes, como por exemplo, disposição no solo, em aterros sanitários, lançamento nas ETEs, sendo ou não via rede coletora de esgoto, fabricação de tijolos, fabricação de cimento. 


\subsubsection{Lançamento em Lagoas}

O sistema envolve a descarga dos resíduos podendo ser utilizados para armazenamento, adensamento, desaguamento ou secagem, e em alguns casos, para disposição final. Não sendo um dos métodos mais eficientes, é amplamente utilizado quando há disponibilidade de área, pois apresenta baixo custo de implantação e operação simples, quando comparado ao desaguamento mecânico.

Segundo FABER \& NARDOZZI (1972), alguns fatores são importantes na elaboração do projeto, tais como: clima, permeabilidade do solo, características e taxa de sedimentação do resíduo, área requerida, profundidade da lagoa, métodos de limpeza, distribuição uniforme do fluxo e decantação.

GRANDIN (1992), relata que, em lagoas destinadas ao adensamento, podem ser obtidas concentrações de sólidos de 4 a $6 \%$ no prazo de 2 a 3 meses, desde que seja retirado o sobrenadante. Isto foi realizado em escala piloto.

\subsubsection{Descarga em Cursos D’água}

O método da disposição em cursos d'água próximos a ETA é o mais econômico, mas pode acarretar grandes problemas quanto à poluição. Este método possui muitas restrições, podendo ser viável em alguns casos particulares, onde a carga poluidora tem condições de ser absorvida pelo corpo receptor. Quando descarregados em corpos d'água com baixa velocidade, podem formar bancos de resíduos e ocasionalmente causar odores desagradáveis.

\subsubsection{Disposição no Solo}

Apesar de ser um método muito econômico, limitações devem ser feitas com relação a concentração de certos metais e a possível contaminação que podem causar. Portanto deve ser feito um controle das características dos resíduos, visando o controle rigoroso da contaminação. São destacados como desvantagens o aumento na concentração de metais no solo e possivelmente na água subterrânea; adsorsão de fósforo, diminuindo a produtividade do solo; excessiva aplicação do nitrogênio, resultando em transporte de nitrato para a água subterrânea e possíveis efeitos causados pela aplicação de alumínio. 
Segundo GRABAREK \& KRUG (1987), a disposição dos resíduos de ETAs no solo não apresenta inconveniente tanto no crescimento das plantas quanto na questão de lixiviação de alumínio, podendo tornar-se viável e de baixo custo.

O comportamento dos resíduos de ETAs, segundo ELLIOT et al. (1990), é idêntico a de solo de fina textura, apresentando como efeito mais sério a redução da capacidade das plantas em utilizar fósforo.

Deve ser destacado que o sobrenadante obtido através de operações e processos, podem ser utilizado para irrigação, sendo que neste caso deverão ser realizados estudos dos possíveis contaminantes que podem estar presentes.

\subsubsection{Disposição em Aterros Sanitários}

Um dos principais inconvenientes para o uso de aterros sanitários para disposição dos sólidos após desidratação dos resíduos de ETA, é o fato de apresentarem concentrações de sólidos não permissíveis para a disposição.

\subsubsection{Lançamento nas ETEs}

Esta opção é economicamente atrativa, transferindo a responsabilidade pela disposição final para a ETE, devendo ser avaliado alguns fatores como impacto dos resíduos da ETA no sistema de transporte e, principalmente, efeitos nos tratamentos biológicos promovidos pelos resíduos da ETA na ETE.

O transporte dos resíduos da ETA até a ETE pode ser feito via rede coletora de esgoto, através de sistemas de recalques, ou através de caminhões-tanque, sendo que a mais utilizada é o lançamento na rede coletora de esgoto, pois é a mais econômica. Um dos fatores que determina o modo pelo qual os resíduos de uma ETA serão lançados na ETE é a distância entre elas.

As ETEs impõem exigências para o lançamento de resíduos de ETA na rede coletora de esgoto, sendo mais comum a necessidade de equalização da vazão. Outras exigências estão relacionadas à qualidade do resíduo, tais como, neutralização do pH, homogeneização do fluxo, para garantir concentração uniforme; limitação da concentração total de sólidos, de metais pesados ou de componentes que possam causar corrosão, odores ou outras condições indesejáveis. 
Para evitar possíveis interferências no desempenho das ETEs e disposição de seu lodo, devem ser avaliados alguns fatores, tais como: sobrecargas hidráulicas, orgânicas, de sólidos e tóxicos; separação sólido-líquido; processos biológicos de tratamento; espessamento, desidratação e disposição final do lodo de ETEs.

Segundo CARVALHO (2000), a quantidade de resíduo de ETA introduzida na ETE, possivelmente não provocará sobrecarga hidráulica, visto que o percentual volumétrico no esgoto é de, no máximo, $7 \%$.

A rede coletora de esgoto geralmente é projetada com declividade adequada para o transporte de sólidos sanitários, em geral, sendo suficientes para os resíduos de ETAs. TSUTIYA \& HIRATA (2001), diz que de maneira geral, problemas de deposição não são observados com velocidade mínima de 0,8 m/s ou concentração de sólidos menor que $3 \%$.

\subsection{Efeitos nos Processos e Operações das ETEs}

Sabe-se que a maior parte dos resíduos produzidos pelas ETAs, devido às suas características, será recebido pelos decantadores primários e conseqüentemente nos digestores de lodo, anaeróbio ou aeróbio. Portanto, os resíduos de ETAs podem causar interferências no desempenho destas unidades seja através da toxicidade nos digestores de lodo, seja no aumento ou diminuição de diversos parâmetros, tais como turbidez, cor, SST e DQO no efluente final.

Através de estudos em laboratório realizados por ROLAN \& BROWN ${ }^{4}$ apud CORNWELL et al. (1987) para avaliar o desempenho de uma ETE que recebesse resíduos de uma ETA que utiliza sulfato de alumínio como coagulante primário, foram verificadas que a qualidade do sobrenadante nos decantadores primários podem sofrer deterioração com um aumento da quantidade do resíduo de ETA. Entretanto em termos de DBO, o sobrenadante pode apresentar qualidade levemente superior, e a concentração de fósforo pode ser menor, diminuindo com o aumento do resíduo de ETA disposto na ETE.

CARVALHO (2000), relata que, possivelmente, não ocorrerá deterioração no efluente final da ETE que recebe resíduo de ETA que utiliza cloreto férrico como coagulante, já que a qualidade do sobrenadante dos decantadores primários não

${ }^{4}$ ROLAN, A.T.; BROW, J.C. (1974). Effects of treatment plant sludge on the treatment of municipal wastewater. Journal North Carolina Selection AWWA, n. 49, v.1, p.29. 
será deteriorada e que não ocorrerá interferências no desempenho dos processos biológicos de tratamento de esgoto.

ESCOBAR (2001), realizando ensaios, em colunas de sedimentação, misturando diferentes proporções de lodo adensado de ETA, que utiliza sulfato de aluminio como coagulante, com esgoto sanitário, concluiu que o sobrenadante clarificado após 2 horas de sedimentação sofreu deterioração em termos de turbidez e SST com o aumento da quantidade de resíduo de ETA.

Trabalhando em escala real, onde o resíduo de uma ETA, que utiliza sulfato de alumínio como coagulante primário, foi lançado diretamente na entrada de uma ETE, conferindo ao esgoto um incremento de $100 \mathrm{mg} / \mathrm{L}$, em termos de sólidos suspensos totais, ROLAN \& MATHEWS ${ }^{5}$ apud CORNWELL et al. (1987), observaram que não houve alteração na DBO; a concentração de SST aumentou de 20 para $40 \mathrm{mg} / \mathrm{L}$; a cor aparente aumentou de 50 para $90 \mathrm{uC}$ e a concentração de fósforo total diminuiu de 7 para $4 \mathrm{mg} / \mathrm{L}$.

CORNWELL et al. (1987) dizem que para quantidades de resíduos de ETA com concentração de sólidos inferiores a $200 \mathrm{mg} / \mathrm{L}$, provavelmente não ocorrerá interferência no processo de lodos ativados, desde que sejam precedidos de decantação primária.

DI BERNARDO et al. (1999a), simulando, em coluna de sedimentação, o lançamento de resíduos de uma ETA, que utiliza sulfato de alumínio como coagulante primário, em decantadores primários de ETE, através da comparação de uma coluna que recebeu apenas esgoto sanitário com três outras colunas, onde foram variadas as quantidades de resíduos adicionados em 7,43\%; 5,70\% e 3,92\% apresentando concentração de SST de 18,45 g/L; 19,93 g/L e 24,08 g/L respectivamente, observam que nas três situações, quando comparadas a coluna controle, ocorreu maior remoção de coliformes totais, Escherichia coli, DQO, nitrogênio, fósforo e cor, sendo que o sobrenadante proveniente da coluna que recebeu maior volume de despejo da ETA apresentou maior remoção destes parâmetros. Quando comparados os valores de turbidez, SST e metais pesados, frente à coluna controle, foram encontrados valores ligeiramente maiores, nas colunas que receberam os resíduos de ETA. Concluiu-se com base nos resultados obtidos nos ensaios de atividade metanogênica, dos sedimentos resultantes dos

\footnotetext{
${ }^{5}$ ROLAN, A.T.; MATTHEWS, L.(1975). A study of the effect water treatment plant sludge on the northside wastewater plant. City od Durham, N.c. International Report.
} 
ensaios em colunas de sedimentação que, possivelmente não ocorrerá interferências significativas no desempenho dos digestores de lodo.

CARVALHO (1999) diz que a eficiência de sedimentação dos decantadores primários pode ser aumentada, uma vez que os testes de sedimentação indicaram que houve um incremento na remoção de SST e turbidez, quando a relação volumétrica entre os resíduos da ETA e do esgoto sanitário aumentou e, concluiu através dos testes de tratabilidade anaeróbia de lodos, que possivelmente não ocorrerá inibição no processo de digestão de lodos de uma ETE que passe a receber os despejos de uma ETA que utiliza cloreto férrico como coagulante primário. Destaca também que os resultados obtidos em seu estudo não devem ser generalizados, pois as ETAs produzem resíduos com características distintas.

CARVALHO (2000), em estudo simulando o lançamento de resíduos de ETA que utiliza cloreto férrico como coagulante primário em ETE com decantação primária, diz que em dosagens de até $225 \mathrm{mg} \mathrm{ST/L}$, possivelmente não causarão efeitos prejudiciais no desempenho das ETEs.

\subsection{Toxicidade em Processos Anaeróbios}

Os despejos industriais freqüentemente contêm substâncias tóxicas ou inibidoras do processo anaeróbio. Via de regra, a toxicidade ou inibição é detectada por aumento na concentração de ácidos voláteis e diminuição na produção de metano.

CARAVALHO (2000), com base nos resultados dos teste de tratabilidade anaeróbia, diz que, possivelmente o resíduo de ETA, que utiliza cloreto férrico, não prodizirá inibição no processo de digestão anaeróbia de lodos, pois não indicaram efeito negativo na taxa de produção de metano, e recomenda verificar os efeitos na digestão aeróbia.

ESCOBAR (2001), em estudos realizados para dispor o lodo adensado da água de lavagem de filtro da ETA-Rio Descoberto - Brasilia, obteve melhores resultados dispondo este lodo em biodigestor anaeróbio. A relação volumétrica entre o lodo adensado e o lodo anaeróbio foi de $86 \%$, sendo que razões volumétricas maiores poderão provocar efeitos inibitórios.

SPEECE (1996), cita os metais pesados catalisadores de processos químicos, como sendo um dos principais tóxicos presentes nos despejos que pode 
oferecer toxicidade aos processos anaeróbios. Além deste, sulfato, sulfitos, sulfetos, Nitrogênio amoniacal, metais alcalinos e alcalinos terrosos são considerados substâncias tóxicas ao processo aneróbio, acima de determinadas concentrações.

\subsection{Toxicidade em Processos Aeróbios}

ESCOBAR (2001), realizando ensaios para disposição de lodo adensado da lavagem de filtros em biodigestor aeróbio de uma ETE, obteve efeito desfavorável da mistura, pois em todos os reatores ocorreram quedas de Taxa de Consumo de Oxigênio de até 50\%, e a composição micorbiana também sofreu efeito inibitório à medida que foi aumentada a fração de lodo de ETA nos ensaios de digestão aeróbia. Neste estudo verificou que para não ocorrer efeito inibitório a mistura não deverá exceder $24 \%$ de lodo de ETA.

A taxa de consumo de oxigênio (TCO) é utilizada para determinar a velocidade de processos metabólicos nos sistemas de tratamento aeróbio com lodo em suspensão, podendo ser utilizado para determinação da toxicidade.

VAN HAANDEL \& MARAIS (1999), dizem que na maioria dos sistemas de lodo ativado a TCO geralmente se situa na faixa de 30 a $100 \mathrm{mg} / \mathrm{L}$.h (taxa baixa e alta, respectivamente). Cita que o teste pode ser realizado no próprio reator do sistema de lodo ativado ou em reatores em escala de laboratório, podendo o sistema estar ou não sendo alimentado. 


\section{METODOLOGIA}

\subsection{INTRODUÇÃO}

Os resíduos; água de lavagem de filtro e descarga de decantadores, utilizados na pesquisa foram obtidos nas Estações de Tratamento de Água das cidades de São Carlos (ETA-SC) e Araraquara (ETA-Fonte), que utilizam como coagulante primário sulfato de alumínio e cloreto férrico, respectivamente. Atualmente estes resíduos são lançados diretamente no Córrego Monjolinho em São Carlos e no Córrego da Servidão em Araraquara.

$\mathrm{O}$ trabalho foi dividido em duas fases. Na primeira foi estudada apenas a disposição do resíduo da ETASC, e na segunda, do resíduo da ETA-Fonte.

\subsection{PRIMEIRA FASE}

O resíduo de ETA foi coletado na ETA-SC, que é constituída por um conjunto de três decantadores, sendo a limpeza realizada, alternadamente durante o ano, através da abertura de registros situados no fundo, e superficialmente com auxílio de mangueiras de alta pressão. A filtração descendente é a tecnologia de filtração empregada, sendo a lavagem realizada com água no sentido ascensional.

Para efeitos de estudo foi considerado que o volume de água fornecido pela ETA-SC abastecerá uma população que produzirá $80 \%$ deste em forma de esgoto.

Considerando que a maior parte dos resíduos produzidos em uma ETA serão retidos nos decantadores primários de uma ETE, os ensaios foram dirigidos para verificar os possíveis efeitos que poderão ocorrer nestas unidades e nas de tratamento de lodo primário, através da avaliação da toxicidade em condições anaeróbias utilizando como parâmetro a produção de metano.

Na figura 1 é apresentado um fluxograma da primeira fase. 


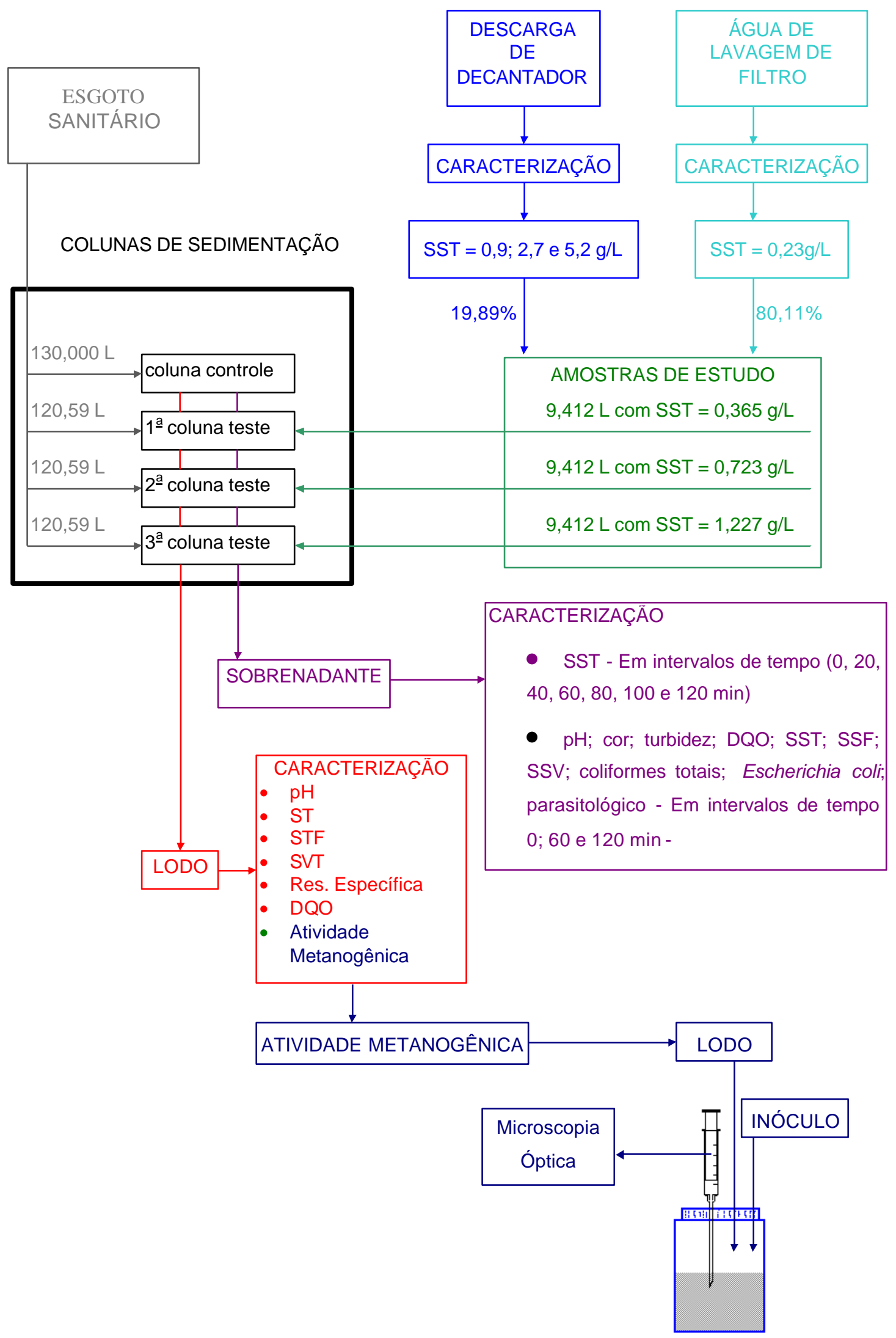

Figura 4.1 - Fluxograma da primeira fase. 


\subsubsection{Dados Operacionais da Estação de Tratamento de Água de São Carlos}

O levantamento dos dados relativos ao funcionamento da ETA-SC foi realizado através da análise dos relatórios dos registros operacionais, de onde ficou conhecido o volume de água produzido pela ETA-SC além do volume dos resíduos oriundos da limpeza dos decantadores e lavagens dos filtros, essencialmente importante para evidenciar o volume que foi misturado ao esgoto sanitário para realização dos ensaios em laboratório.

\subsubsection{Obtenção do Esgoto Sanitário}

O esgoto sanitário foi coletado, após gradeamento, de uma derivação da rede coletora de esgoto da cidade de São Carlos, situada próximo a EESC-USP. O esgoto coletado com auxílio de uma bomba foi transferido para um tanque de equalização, com capacidade para $1000 \mathrm{~L}$, provido de agitador para manter a homogeneização do esgoto sanitário.

\subsubsection{Obtenção e Caracterização do Resíduo da Limpeza do Decantador}

O resíduo da limpeza do decantador foi obtido na ETA-SC no canal de distribuição que antecede o decantador, com intuito de simular o funcionamento de um decantador de alta taxa com descarga diária, apresentando concentrações de sólidos da ordem de 3,0 g/L. O resíduo da limpeza do decantador foi retirado deste canal visto que o tempo de permanência é o mesmo do resíduo obtido na descarga de fundo do decantador, além do que, este resíduo foi preparado para apresentar teor de sólidos da ordem de $3,0 \mathrm{~g} / \mathrm{L}$.

O teor de sólidos desejado foi conseguido deixando-se sedimentar e retirando-se parte do sobrenadante, ou adicionando-se sobrenadante quando estava com concentração superior a desejada. Desta forma preparou-se resíduo da limpeza do decantador com teor de sólidos da ordem de $3 \mathrm{~g} / \mathrm{L}$. Visando possíveis variações preparou-se duas outras amostras com teor de sólidos da ordem de $1 \mathrm{~g} / \mathrm{L}$ e $5 \mathrm{~g} / \mathrm{L}$, apresentando, respectivamente, teor de sólidos abaixo e acima de $3 \mathrm{~g} / \mathrm{L}$. 
Estas amostras foram caracterizadas segundo os parâmetros contidos na tabela 4.1 .

Tabela 4.1 - Parâmetros que foram medidos no resíduo da descarga do decantador utilizado no ensaio de sedimentação.

\begin{tabular}{c}
\hline PARÂMETROS \\
\hline Turbidez (UT) \\
Sólidos Suspensos Totais $(\mathrm{mg} / \mathrm{L})$ \\
Sólidos Suspensos Fixos $(\mathrm{mg} / \mathrm{L})$ \\
Sólidos Suspensos Voláteis $(\mathrm{mg} / \mathrm{L})$ \\
$\mathrm{pH}$ \\
$\mathrm{DQO}(\mathrm{mg} / \mathrm{L})$ \\
\hline
\end{tabular}

\subsubsection{Obtenção e Caracterização da Água de Lavagem de Filtro}

A água de lavagem de filtro foi coletada na ETA-SC com o auxílio de uma bomba instalada na canaleta central de um filtro, próximo a descarga, onde a mistura do resíduo era mais eficiente. A amostra foi coletada, com vazão constante, do início ao final da lavagem, formando uma amostra composta, que foi caracterizada seguindo os parâmetros contidos na tabela 4.2.

Tabela 4.2 - Parâmetros que foram medidos na água de lavagem de filtro utilizada no ensaio de sedimentação.

\begin{tabular}{c}
\hline PARÂMETROS \\
\hline Turbidez $(\mathrm{UT})$ \\
Sólidos Suspensos Totais $(\mathrm{mg} / \mathrm{L})$ \\
Sólidos Suspensos Fixos $(\mathrm{mg} / \mathrm{L})$ \\
Sólidos Suspensos Voláteis $(\mathrm{mg} / \mathrm{L})$ \\
$\mathrm{pH}$ \\
DQO $(\mathrm{mg} / \mathrm{L})$ \\
\hline
\end{tabular}




\subsubsection{Descrição das Instalações}

As instalações utilizadas foram um tanque para equalização do esgoto sanitário e as colunas de sedimentação para simular decantadores primários. As instalações estão descritas a seguir.

\subsubsection{Tanque de Equalização e Homogeneização do Esgoto Sanitário}

Inicialmente, após gradeamento, o esgoto sanitário foi bombeado para um tanque de equalização provido de agitador, o qual permaneceu ligado para manter a homogeneização do esgoto.

Na figura 4.2 pode ser observada a fotografia do tanque de equalização, sendo uma caixa de amianto com capacidade para 1000L, apresentando na parte superior o agitador e, na parte inferior, uma saída por onde foi realizada a transferência do esgoto sanitário para as colunas de sedimentação.

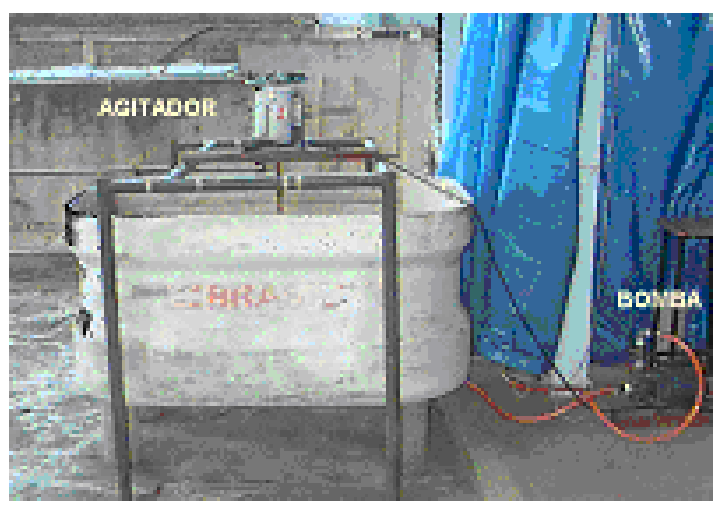

Figura 4.2 - Fotografia ilustrando a caixa de amianto, com capacidade para $1000 \mathrm{~L}$, que foi responsável pelo armazenamento, e o agitador localizado na parte superior da caixa e a bomba de recalque.

\subsubsection{Descrição das Colunas de Sedimentação}

Os ensaios de sedimentação foram realizados em quatro colunas construídas em acrílico, apresentando 0,30 m de diâmetro e 2,20 m de altura, com volume útil de $130 \mathrm{~L}$. A parte inferior é constituída de uma estrutura cônica de 0,20 $\mathrm{m}$, localizado em sua extremidade um registro para retirada do lodo. Ao longo de 
sua extensão estão distribuídos 3 pontos de coletas. Interiormente, movido por um motor, apresenta um eixo onde foram fixadas paletas, que tiveram como finalidade a manutenção da mistura das amostras no interior da coluna durante o ensaio. $\mathrm{Na}$ figura 4.3 é mostrado a fotografia e o esquema das colunas utilizadas nos ensaios.

(A)

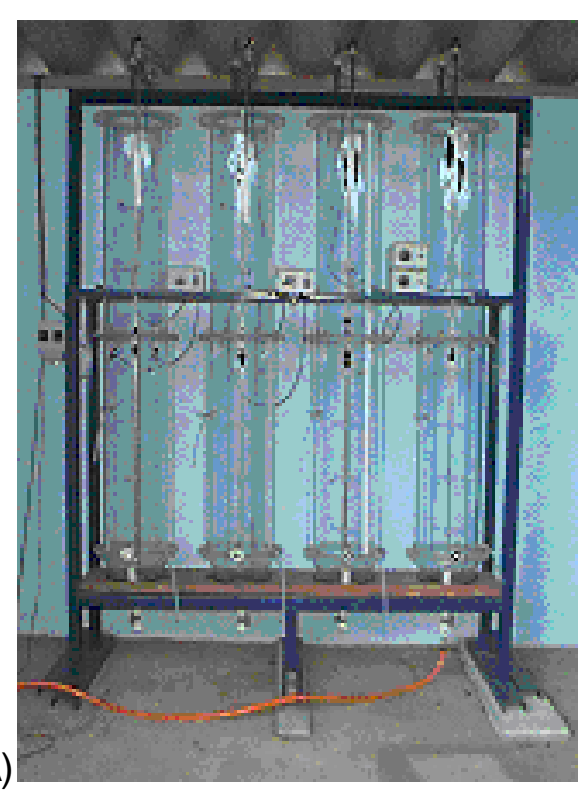

(B)

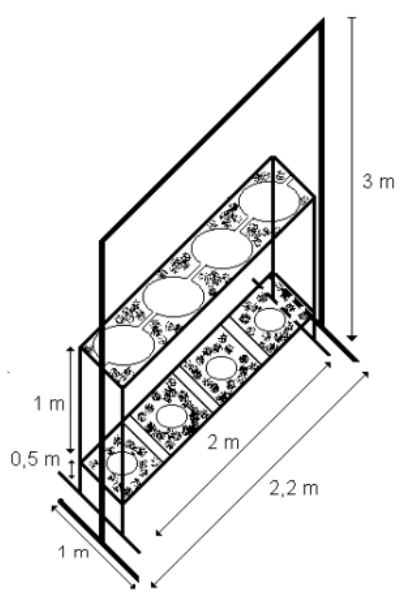

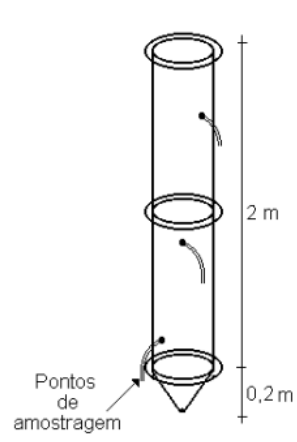

amostragem

Figura 4.3 - Colunas de sedimentação que foram utilizadas nos ensaios de sedimentação. (A) Fotografia ilustrando as colunas de sedimentação; (B) esquema das colunas de sedimentação.

\subsubsection{Efeitos nos Decantadores Primários de uma ETE}

\subsubsection{Condições Iniciais}

Através do levantamento de dados operacionais da ETASC durante o ano de 1999 ficou conhecido o volume médio mensal da água produzida, 1121522,29 $\mathrm{m}^{3} / \mathrm{mês}$, bem como o volume médio mensal de resíduos gerados durante a limpeza dos decantadores, $1375,00 \mathrm{~m}^{3} / \mathrm{mês}$, e lavagem dos filtros, $56076,12 \mathrm{~m}^{3} / \mathrm{mês}$.

O volume de esgoto gerado foi considerado como sendo $80 \%$ do volume de água produzido, representado $897217,84 \mathrm{~m}^{3} / \mathrm{mês}$.

Foi considerando o teor de sólidos de $30,275 \mathrm{~kg} / \mathrm{m}^{3}$, determinado por CORDEIRO (1993), originando uma massa total de sólidos de 41628,13kg/mês. Para simular um resíduo obtido na descarga de um decantador de alta taxa, com teor de sólidos da ordem de $3,0 \mathrm{~g} / \mathrm{L}$, o volume de resíduo gerado foi de 
aproximadamente $13876,00 \mathrm{~m}^{3} / \mathrm{mês}$, representando $1,24 \%$ do total de água produzido.

Nos ensaios realizados, o teor de sólidos no resíduo da limpeza do decantador foi de 1,3 e $5 \mathrm{~g} / \mathrm{L}$.

\subsubsection{Ensaios de Sedimentação}

A simulação dos efeitos, produzidos em um decantador primário de uma ETE, foram avaliadas através de três ensaios realizados em colunas de sedimentação, onde foram utilizadas amostras compostas por esgoto sanitário e resíduo, em diferentes concentrações, provenientes da limpeza do decantador e da lavagem dos filtros da ETA-SC.

Os ensaios forram realizados em uma bateria de 4 colunas de sedimentação, sendo 3 colunas teste que receberam, além de esgoto sanitário o resíduo de ETA, e, uma coluna controle que recebeu apenas esgoto sanitário.

O esgoto sanitário foi transferido para as colunas de sedimentação, mantendo-se os agitadores do tanque de equalização e das colunas ligados.

Todas as colunas receberam o mesmo volume de esgoto sanitário. Após o enchimento das colunas foram retirados volumes de esgoto sanitário iguais aos de resíduos da ETA-SC que serão adicionados, exceto na coluna controle que permaneceu apenas com esgoto sanitário. O tempo de mistura adotado foi de 30 minutos com gradiente de velocidade da ordem de $300 \mathrm{~s}^{-1}$, simulando o tempo que este resíduo levaria para chegar à ETE. Após este tempo os agitadores foram desligados e assim que a superfície da água se estabilizava era cronometrado o tempo de sedimentação, que foi de duas horas, visto que, equivale ao tempo de detenção hidráulico médio, utilizado nos projetos dos decantadores primários. Durante o tempo de sedimentação foram coletadas, nos três pontos de coletas, amostras em intervalos de 20 minutos para determinação de turbidez e sólidos suspensos totais. Entretanto, nos tempos de 0,60 e 120 minutos foram coletadas amostras do sobrenadante suficiente para caracterização em termos de DQO, pH, cor, turbidez, sólidos, alcalinidade, sulfato, coliformes, parasitológico, metais, nitrogênio e fósforo.

O lodo, obtido após duas horas de sedimentação, foi retirado através do registro localizado na extremidade inferior da coluna e, posteriormente, 
caracterizado em termos de $\mathrm{DQO}, \mathrm{pH}$, sólidos e resistência específica, e submetidos a ensaio de atividade metanogênica.

O ensaio foi realizado para avaliar os efeitos produzidos em um decantador primário de uma ETE quando receber resíduo da limpeza de decantador e água de lavagem de filtro, simultaneamente.

Em uma coluna foi colocado o resíduo da limpeza do decantador com concentração de sólidos da ordem de $3 \mathrm{~g} / \mathrm{L}$. Nas duas outras colunas foram extrapolados valores de sólidos acima, $5 \mathrm{~g} / \mathrm{L}$, e abaixo, $1 \mathrm{~g} / \mathrm{L}$, da situação real de $3 g / L$, objetivando prever possíveis variações diárias na relação esgoto sanitário e resíduo da limpeza de decantador.

Neste ensaio o volume do resíduo da limpeza do decantador e o volume e concentração de sólidos do resíduo da lavagem de filtros foram mantidos constantes em todas as colunas de sedimentação.

\subsubsection{Efeitos nos Digestores Anaeróbios de Lodo de ETE}

Os possíveis efeitos nos digestores de lodo anaeróbio foram analisados através do teste de atividade metanogênica do lodo primário obtido dos ensaios realizados nas colunas de sedimentação envolvendo esgoto sanitário e os resíduos da ETA-SC. Para isto foi utilizado um inóculo de um digestor de lodo anaeróbio em funcionamento, ETE-Piracicaba.

\subsection{SEGUNDA FASE}

Nesta fase foram estudadas as possíveis interferências que poderão advir na unidade de escala piloto simulando a ETE-Araraquara, após receber resíduo da ETA-Fonte, que utiliza cloreto férrico como coagulante primário, verificando o desempenho das lagoas de aeração e de sedimentação, além do processo de desidratação do lodo obtido na lagoa de sedimentação, complementando com ensaios de lixiviação e solubilização. $\mathrm{Na}$ figura 4.4 pode ser observado $\mathrm{O}$ fluxograma desta fase.

Este estudo poderá ser decisivo na opção pelo lançamento do resíduo, produzido pela ETAFonte, na ETE-Araraquara, gerando uma substancial economia, não sendo necessário a implantação de um sistema exclusivo para o tratamento do resíduo gerado na ETA-Fonte. 


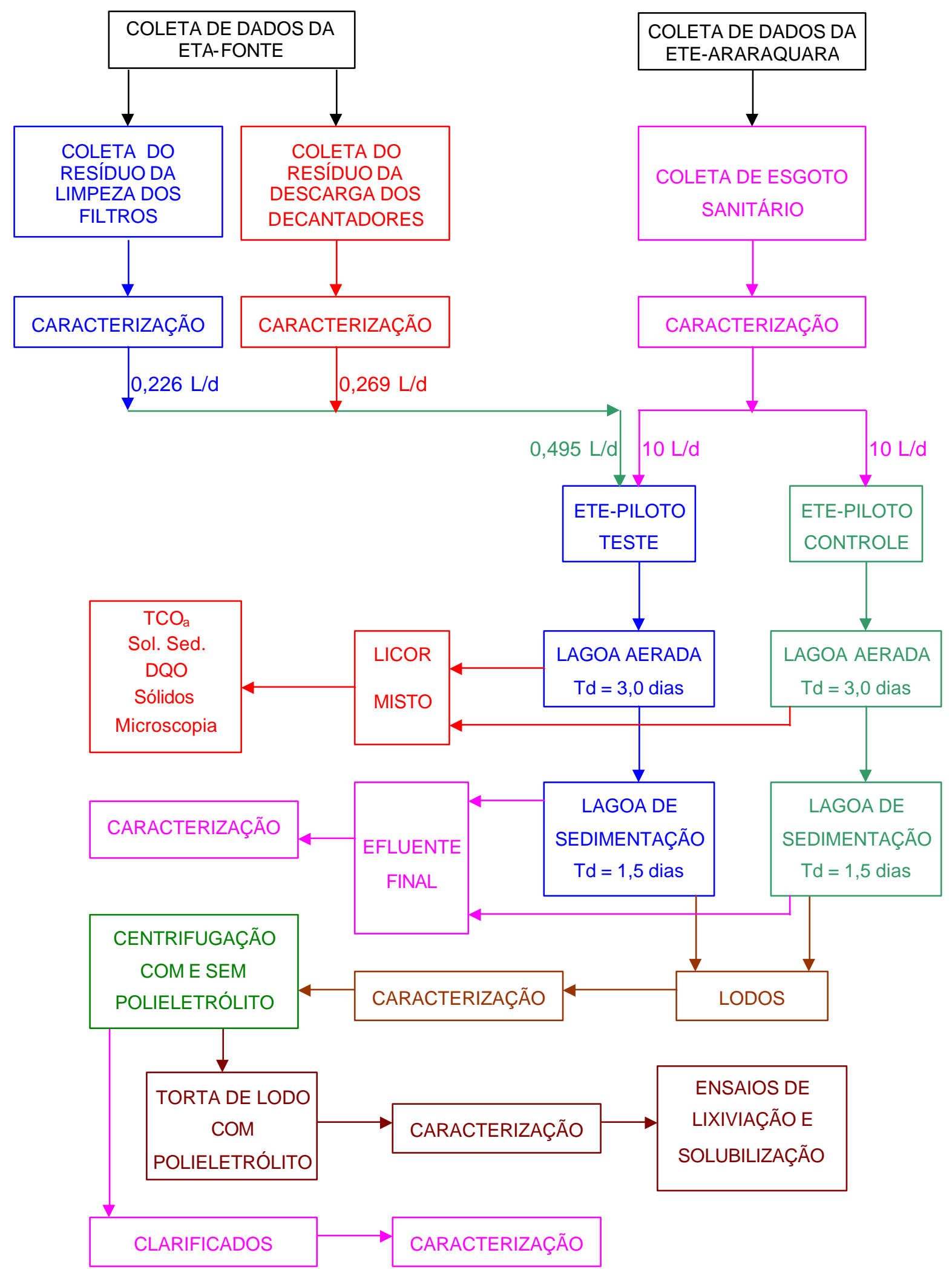

Figura 4.4 - Fluxograma da segunda fase. 


\subsubsection{Dados Operacionais da Estação de Tratamento de Esgoto de Araraquara}

A Estação de Tratamento de Esgotos de Araraquara (ETE-Araraquara), cuja construção teve início em dezembro de 1998, iniciando sua operação em outubro de 1999, foi projetada para tratar $100 \%$ do esgoto coletado a partir de um Estudo de Concepção elaborado em julho de 1996, por empresa especializada, contratada por processo de licitação, que analisou a possibilidade de implantação de três processos de tratamento, Lagoas aeradas seguidas de lagoas de sedimentação; Lodos ativados na versão convencional; Reatores anaeróbios seguidos de filtros biológicos aeróbios. Além dos tipos de tratamentos o Estudo de Concepção levou em consideração alguns fatores tais como área de implantação, consumo de energia, custo de manutenção, dentre outros.

A conclusão do Estudo de Concepção viabilizou, técnica e financeiramente, a alternativa 1 - Lagoas aeradas seguidas de lagoas de sedimentação com a construção de uma única ETE e a execução de 14,9 km de interceptores, o que levou ao afastamento da estação em relação a área urbana do município.

A cidade de Araraquara conta com 185.000 habitantes, 62.167 ligações domiciliares de água e esgoto, $904 \mathrm{~km}$ de redes de água, $823 \mathrm{~km}$ de redes de esgoto, produção média de $70.000 \mathrm{~m}^{3} /$ dia de água tratada para abastecimento público com capacidade para reservação de $44.100 \mathrm{~m}^{3}$ e tratamento médio de $45.000 \mathrm{~m}^{3} /$ dia de esgoto, correspondendo a $100 \%$ no abastecimento de água e $98 \%$ na coleta de esgoto (dados referentes a julho de 2001). A ETE trata $100 \%$ do esgoto coletado no município.

Está localizada na Bacia hidrográfica do Médio Tietê Inferior, UGRHI Tietê/Jacaré, tendo como corpo receptor o Ribeirão das Cruzes - enquadrado como rio classe 4, responsável pelo tratamento de esgotos domésticos municipais da cidade de Araraquara tendo como processo de tratamento lagoas de aeração e de sedimentação, com eficiência igual ou superior a $80 \%$, em termos remoção da $\mathrm{DBO}_{5}$ dos esgotos afluentes, de acordo com a legislação ambiental vigente no estado de São Paulo.

Foram previstos 3 módulos de tratamento, cada um formado por uma lagoa aerada, uma lagoa de sedimentação e uma lagoa de lodo.

O esgoto é enviado ao sistema de tratamento através de emissários com $1.000,1.200$ e $1.500 \mathrm{~mm}$ de diâmetro, que é composto por um tratamento preliminar constituído por um sistema de gradeamento com espaçamento de $20 \mathrm{~mm}$ 
e processo de remoção automática de detritos, caixas de areia mecanizadas equipadas com raspador de fundo do tipo circular e remoção para caçambas externas através de roscas transportadoras helicoidais. Posteriormente passam por peneiras mecanizadas com espaçamento de $6 \mathrm{~mm}$, sendo os resíduos lançados em uma caçamba através de esteira transportadora, também com funcionamento automático. Em seguida os esgotos são encaminhadas para a caixa de distribuição de vazão, onde, são seguem para as lagoas de aeração, com volume útil da ordem de 103.700,0 $\mathrm{m}^{3}$, o suficiente para um tempo de detenção médio de 3 dias , considerando a vazão nominal média de cada módulo de 400,0 L/s. Em seguida são enviados para as Lagoas de Sedimentação, com volume útil da ordem de $57.600,0 \mathrm{~m}^{3}$, o suficiente para proporcionar um tempo de detenção de 1,7 dia, considerando a vazão média nominal de 400,0 L/s por módulo, onde, os sólidos sedimentáveis presentes no efluente das lagoas aeradas são sedimentados. O efluente das lagoas de sedimentação é enviado para o Ribeirão das Cruzes e o lodo sedimentado no fundo das lagoas será estabilizado por processos anaeróbios e deverá ser removido periodicamente.

Os dados de projeto dos módulos de tratamento da ETE-Araraquara estão contidos na tabela 4.3. Na tabela 4.4 estão os custos envolvidos na construção da ETE-Araraquara.

Tabela 4.3 - Dados de projeto de construção da ETE-Araraquara

\begin{tabular}{lccc}
\hline Módulo de Tratamento & Dimensões $(\mathrm{m})$ & Volume $\left(\mathrm{m}^{3}\right)$ & Tempo de Detenção \\
\hline Lagoas de Aeração & $240 \times 125 \times 4,7$ & 103700 & 3 dias \\
Lagoas de Sedimentação & $130 \times 125 \times 4,7$ & 57600 & 1,7 dias \\
Lagoas de Lodo & $60 \times 125 \times 2,7$ & 23000 & 1 a 4 anos \\
\hline
\end{tabular}

Tabela 4.4 - Valores gastos na construção da ETE-Araraquara, emissários e compras de equipamentos.

Obras $\quad$ Valores gastos (U\$)

Custos para construção da ETE-Araraquara, Emissários e Equipamentos. 
Na figura 4.6 é apresentado o fluxograma da ETE-Araraquara com as fases do tratamento. Convém ressaltar que as lagoas de lodo não estão funcionando, pois não foi produzido lodo suficiente nas lagoas de sedimentação para início da remoção. Na figuras 4.7 e 4.8 são apresentadas fotografias ilustrando as Lagoas de Aeração e Sedimentação da ETE-Araraquara em escala real.

O volume médio de esgoto tratado pela ETE-Araraquara no ano de 2002 foi de 1.158.023,64 $\mathrm{m}^{3} / \mathrm{mês}$, caracterizando um consumo médio de energia elétrica de $529720,92 \mathrm{kwh} / \mathrm{mês}$, gerando um gasto de $\mathrm{R} \$ 67.054,55 / \mathrm{mês}$, representando um custo de $\mathrm{R} \$ 0,057$ o $\mathrm{m}^{3}$ de esgoto tratado.

\subsubsection{Obtenção do Esgoto Sanitário}

O esgoto sanitário, utilizado na pesquisa, foi obtido por meio de uma bomba, de fluxo contínuo, instalada no canal de entrada da ETE-Araraquara (ver figura 4.5A). Esta bomba mantinha um fluxo constante em uma rede de PVC de onde era retirada a vazão necessária para alimentar a ETE-Piloto com auxílio de bomba dosadora. O esgoto sanitário foi caracterizado quanto a

Para evitar entupimentos na captação do esgoto, foi adaptada uma peneira protegendo a sucção da bomba (ver Fotografia da figura 4.5-B).
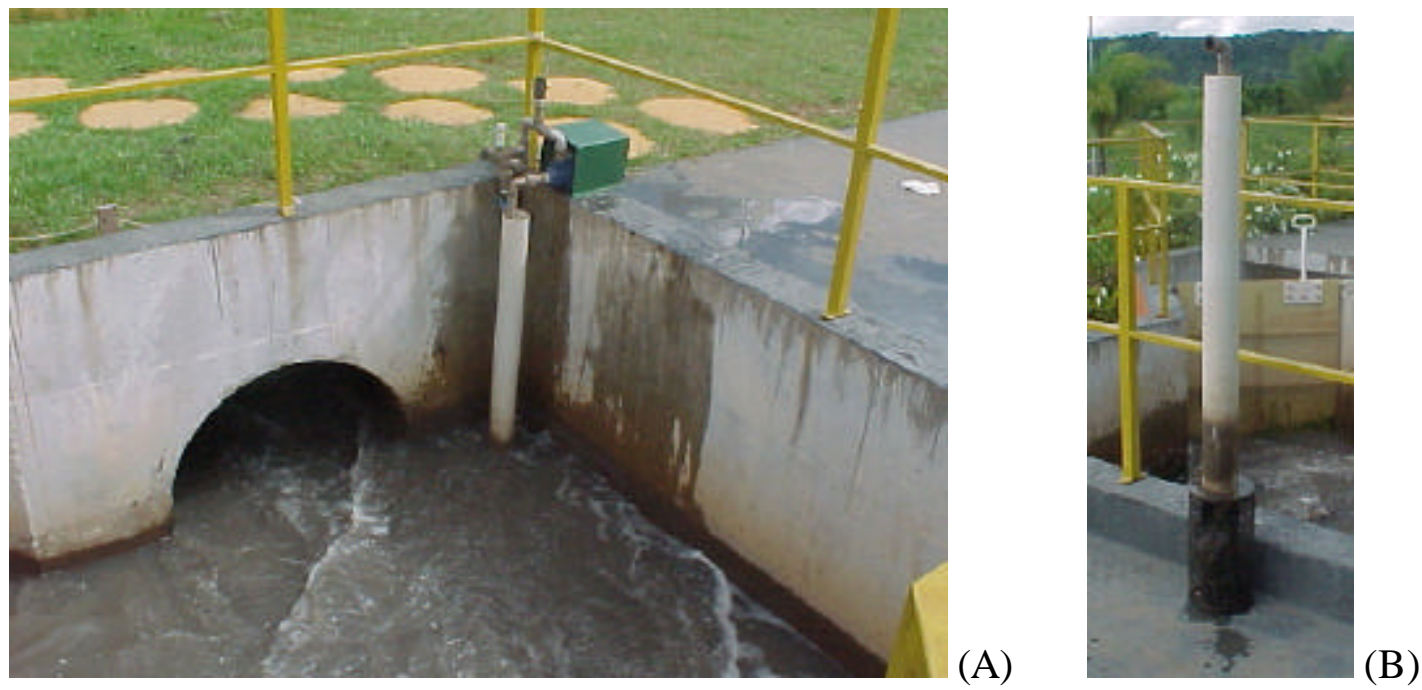

Figura 4.5 - (A) Bomba de fluxo contínuo, instalada no canal de entrada da ETEAraraquara, responsável para coleta e envio do esgoto sanitário até as bombas dosadoras; (B) Sistema de gradeamento para evitar entupimentos. 


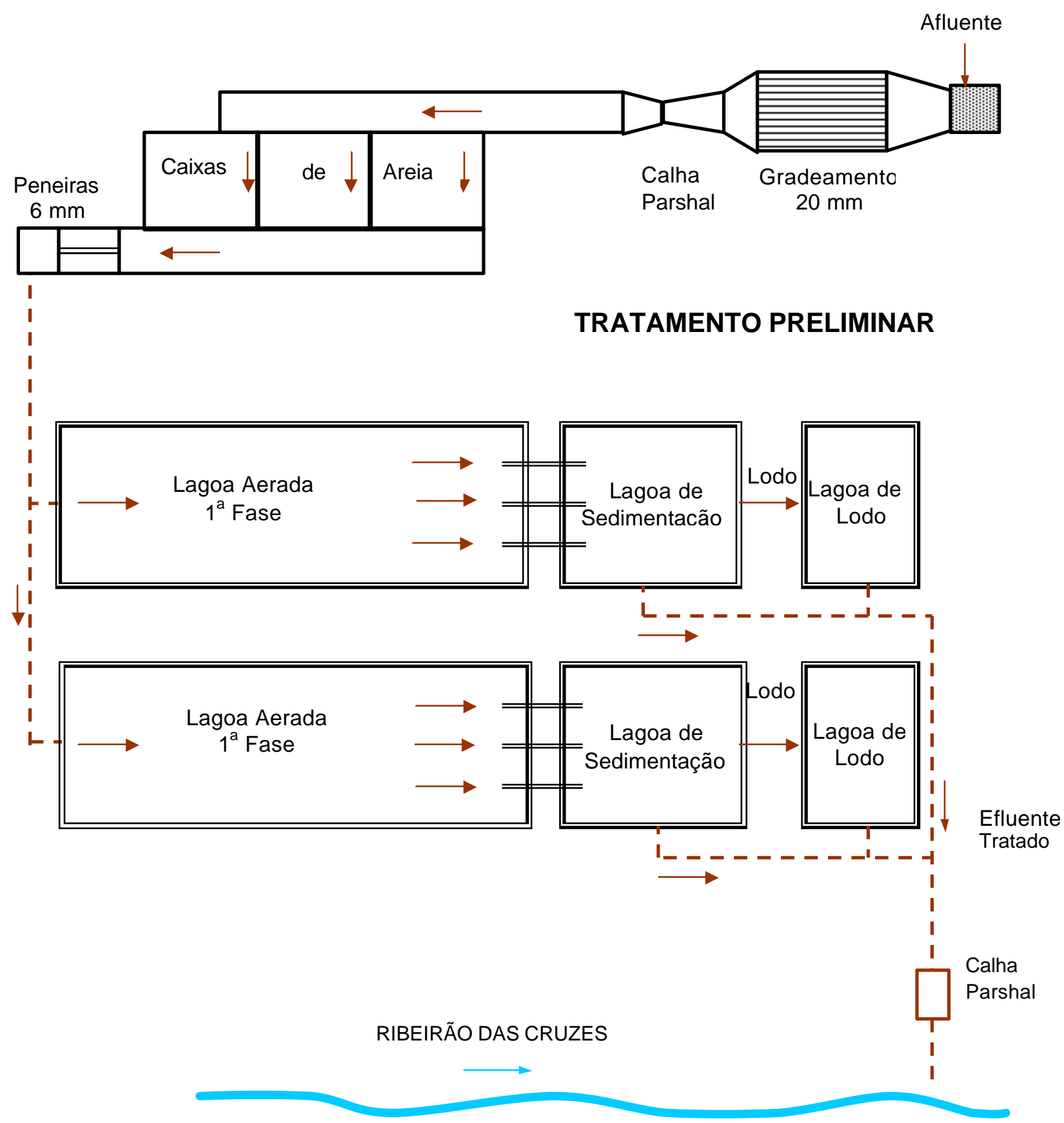

Figura 4.6 - Fluxograma da ETE-Araraquara. 


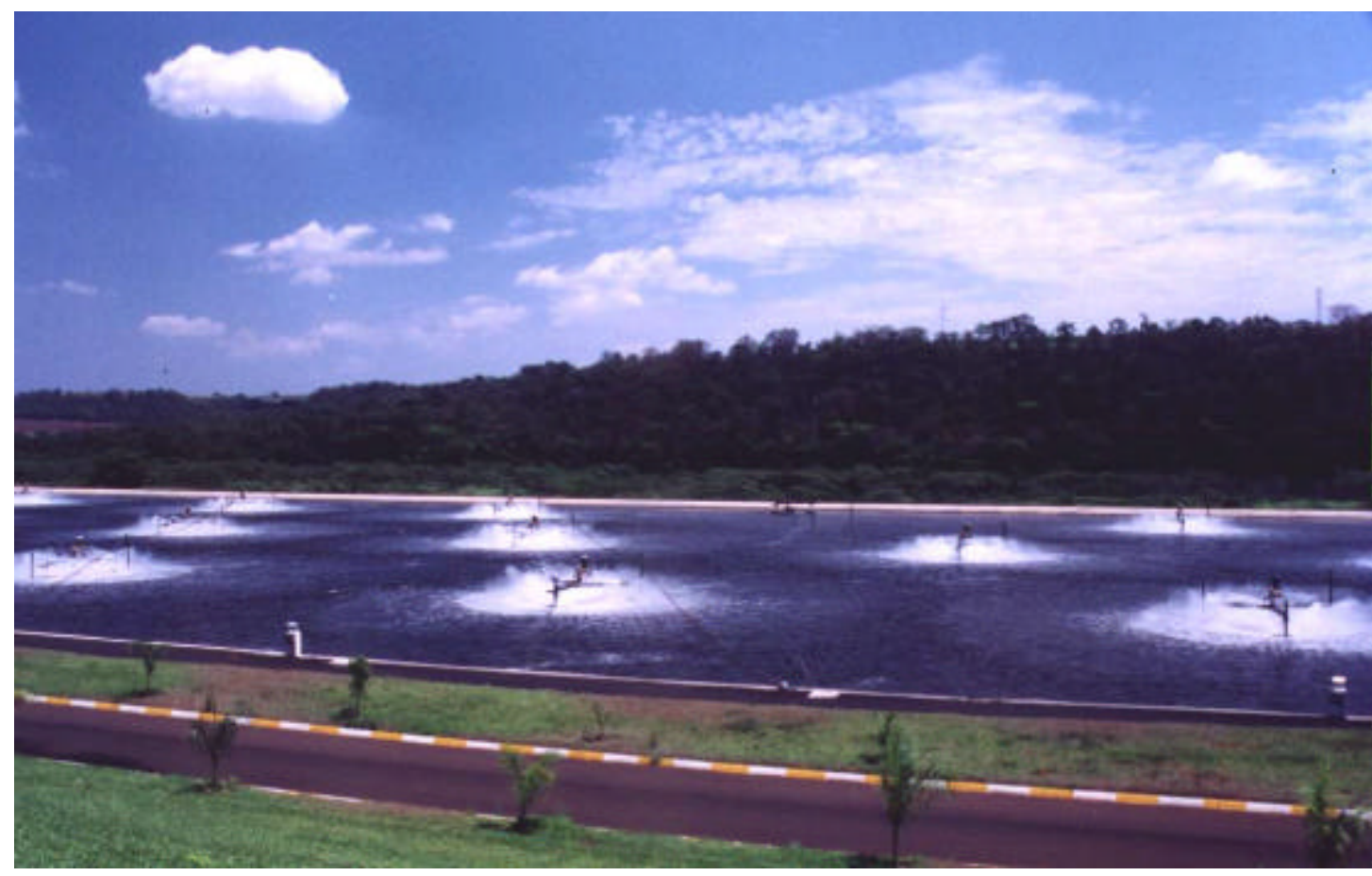

Figura 4.7 - Fotografia ilustrando a Lagoa de Aeração da ETE-Araraquara, constituída por aeradores superficiais com potência de $40 \mathrm{cv}$.

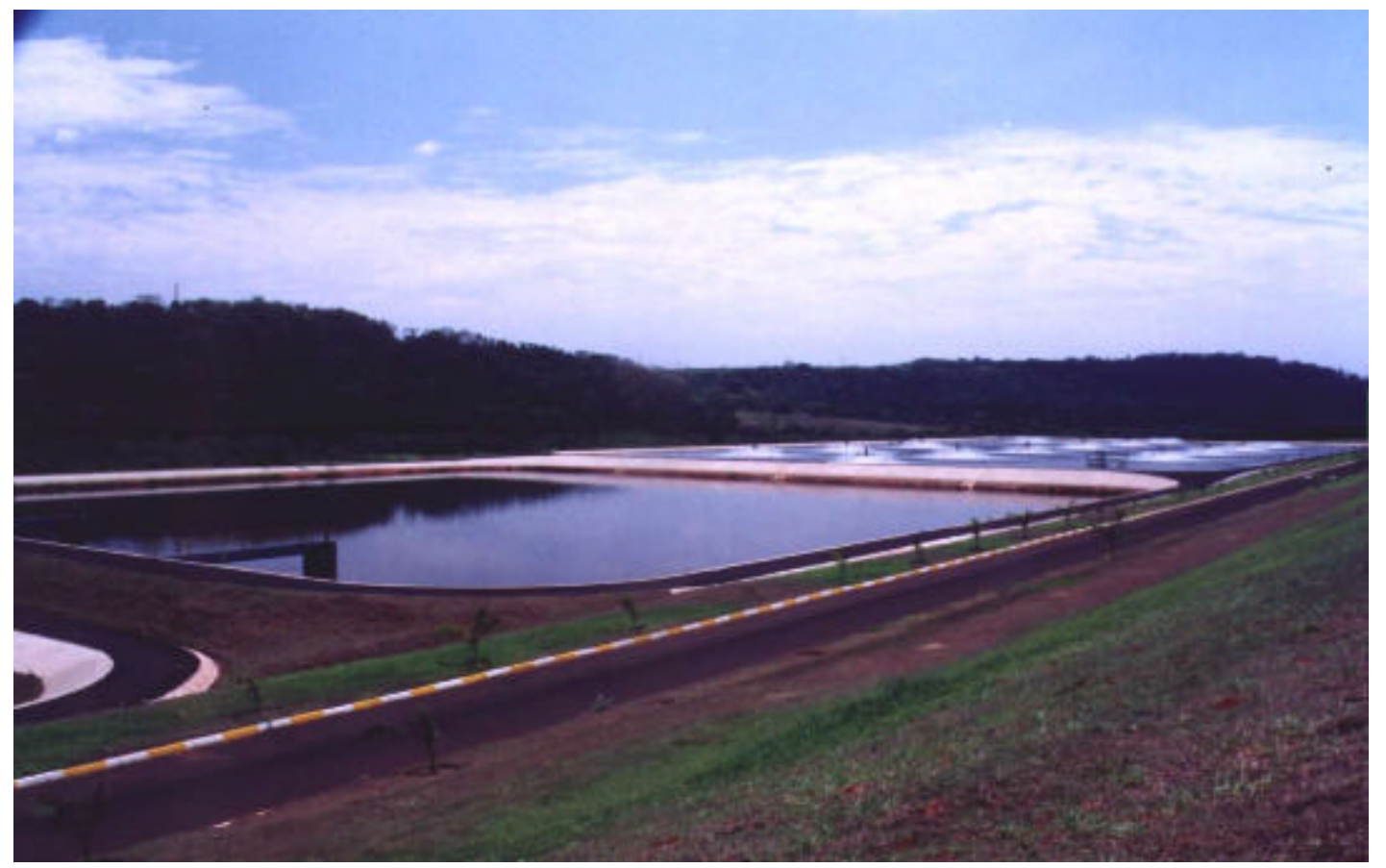

Figura 4.8 - Fotografia ilustrando as Lagoas de Aeração e de Sedimentação da ETE-Araraquara. 
Tabela 4.5 - Valores médios dos parâmetros analisados no ano de 2002 para 0 afluente e efluente da ETE-Araraquara.

\begin{tabular}{|c|c|c|}
\hline Parâmetros & Afluente & Efluente \\
\hline $\mathrm{DQO}(\mathrm{mg} / \mathrm{L})$ & 729,7 & 141,3 \\
\hline $\mathrm{DBO}(\mathrm{mg} / \mathrm{L})$ & 327,2 & 63,4 \\
\hline Remoção de DQO (\%) & NR & 80,6 \\
\hline Remoção de DBO (\%) & NR & 80,6 \\
\hline $\mathrm{pH}$ & 6,8 & 7,2 \\
\hline Condutividade elétrica (us/cm) & 543 & 522 \\
\hline $\mathrm{ST}(\mathrm{mg} / \mathrm{L})$ & 646 & 363 \\
\hline $\mathrm{SF}(\mathrm{mg} / \mathrm{L})$ & 324 & 270 \\
\hline $\mathrm{SV}(\mathrm{mg} / \mathrm{L})$ & 322 & 93 \\
\hline $\mathrm{SST}(\mathrm{mg} / \mathrm{L})$ & 247 & 53 \\
\hline $\mathrm{SSF}(\mathrm{mg} / \mathrm{L})$ & 62 & 19 \\
\hline $\mathrm{SSV}(\mathrm{mg} / \mathrm{L})$ & 185 & 35 \\
\hline $\mathrm{SDT}(\mathrm{mg} / \mathrm{L})$ & 539 & 310 \\
\hline $\mathrm{SDF}(\mathrm{mg} / \mathrm{L})$ & 262 & 252 \\
\hline $\mathrm{SDV}(\mathrm{mg} / \mathrm{L})$ & 137 & 58 \\
\hline Sólidos Sedimentáveis Cone Imhoff $1 \mathrm{~h}$ (mL/L) & 3,8 & 0,1 \\
\hline Substâncias solúveis em hexano (mg/L) & 88,8 & 22,5 \\
\hline OD (mg/L) & NR & 5,6 \\
\hline Turbidez (UT) & NR & 90,3 \\
\hline Cor (UC) & NR & 118,5 \\
\hline Cloreto (mg Cl$/ \mathrm{L}^{-}$) & 43,7 & 45,3 \\
\hline Nitrogênio Amoniacal (mg N/L) & 16,31 & 13,79 \\
\hline Nitrato (mg N/L) & 0,40 & 2,24 \\
\hline Nitrito (mg N/L) & 0,12 & 1,83 \\
\hline Nitrogênio Total Kjeldahl (mg N/L) & 34,00 & 20,60 \\
\hline Fosforo total (mg P/L) & 8,00 & 6,30 \\
\hline Remoção Nitrogênio (\%) & NR & 39,5 \\
\hline Remoção fósforo (\%) & NR & 20,7 \\
\hline Coliformes Totais (NMP/100mL) & NR & $1,5 \times 10^{6}$ \\
\hline Escherichia coli (NMP/100mL) & NR & $3,3 \times 10^{5}$ \\
\hline Temperatura da amostra no laboratório $\left({ }^{\circ} \mathrm{C}\right)$ & 25,0 & 24,9 \\
\hline
\end{tabular}

NR- não realizado

Fonte: SCALIZE et al (2003). 


\subsubsection{Dados Operacionais da ETAFonte}

O total de água produzido na cidade de Araraquara no ano de 2002 foi de 24.497.048,40 $\mathrm{m}^{3}$, representado uma média de 2.041.420,7 $\mathrm{m}^{3} / \mathrm{mês}$, sendo que $994.358 \mathrm{~m}^{3} /$ mês são produzidos pela ETA-Fonte. Neste período o volume de resíduo gerado pela ETAFonte foi de $32764 \mathrm{~m}^{3} / \mathrm{mês}$ nas descargas de decantadores e $27.495 \mathrm{~m}^{3} / \mathrm{mês}$ nas lavagens de filtros, representando, respectivamente, uma perda de $3,29 \%$ e $2,77 \%$ do total de água produzido pela ETA-Fonte. (ver tabela 4.6 e Figura 4.9).

Tabela 4.6 - Volume Total de água tratada pelo DAAE em comparação ao volume de água aduzido à ETA-Fonte e volume gerado nas descargas dos decantadores e lavagens de filtros, no ano de 2002.

\begin{tabular}{lcccc}
\hline Período & $\begin{array}{c}\text { Volume de } \\
\text { água aduzido } \\
\text { à ETA-Fonte }\end{array}$ & $\begin{array}{c}\text { Volume total de } \\
\text { água tratada } \\
\text { pelo DAAE }\end{array}$ & $\begin{array}{c}\text { Volume de água } \\
\text { gasto nas descargas } \\
\text { de decantadores }\end{array}$ & $\begin{array}{c}\text { Volume de água } \\
\text { gasto nas lavagens } \\
\text { dos filtros }\end{array}$ \\
\hline Janeiro & 1095563 & 1927136,0 & 39489 & 20020 \\
Fevereiro & 975291 & 1751287,1 & 36234 & 15640 \\
Março & 1058449 & 2184516,1 & 26933 & 17474 \\
Abril & 1068144 & 2170217,5 & 37060 & 13120 \\
Maio & 1049478 & 2106892,0 & 39335 & 14960 \\
Junho & 1060961 & 2101784,0 & 45806 & 24000 \\
Julho & 1093280 & 2094069,5 & 47254 & 50340 \\
Agosto & 987144 & 2028362,1 & 31075 & 52420 \\
Setembro & 878527 & 1855045,1 & 25311 & 46280 \\
Outubro & 955139 & 2245326,5 & 22556 & 26744 \\
Novembro & 853189 & 2004637,5 & 19490 & 23660 \\
Dezembro & 857135 & 2027774,6 & 22624 & 25280 \\
Total & 11932300 & 24497048,0 & 393167 & 329938 \\
Média/mês & 994358 & 2041420,7 & 32764 & 27495 \\
$\%$ & 100 & & 3,29 & 2,77 \\
\hline
\end{tabular}




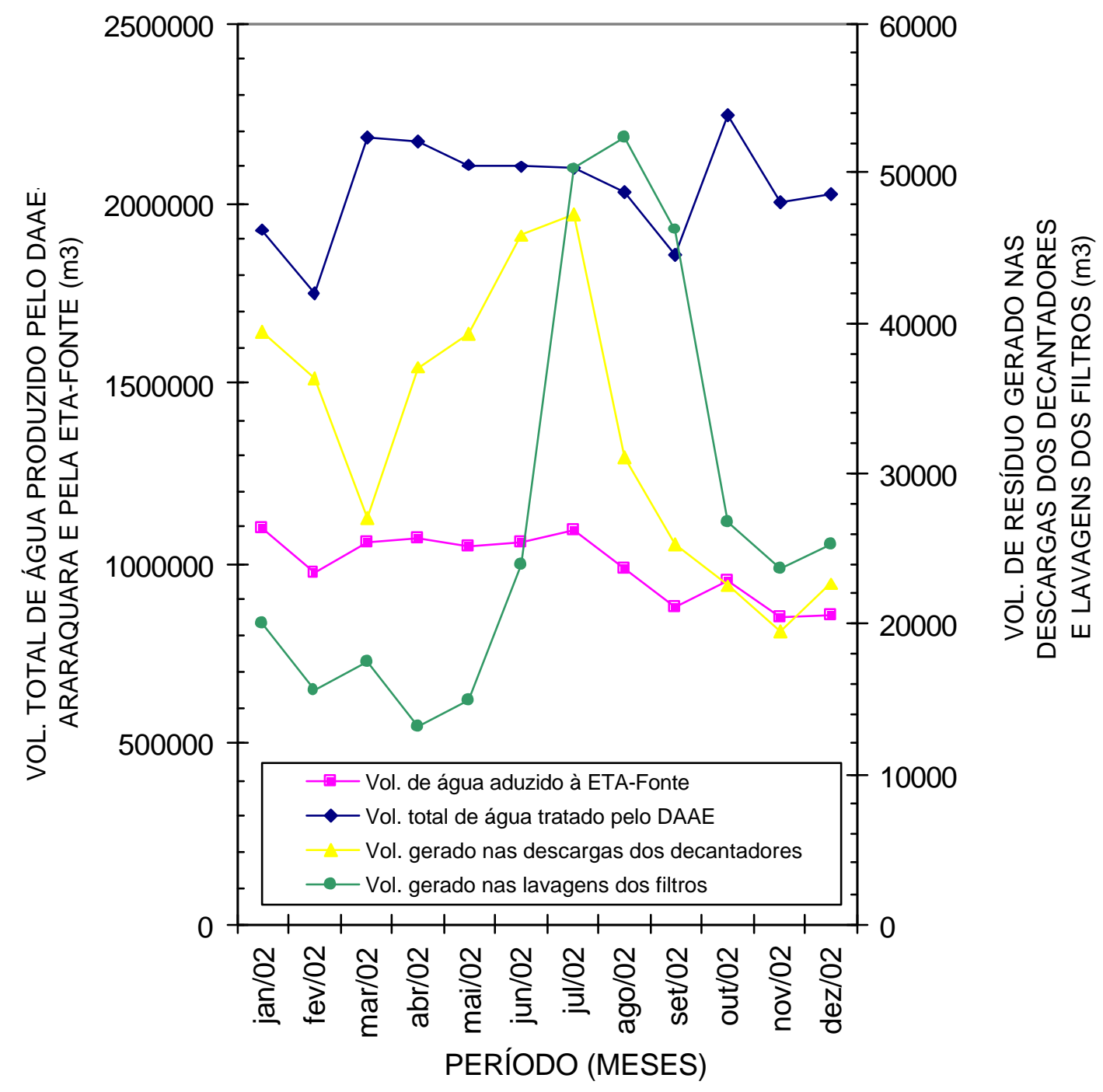

Figura 4.9 - Relação entre o volume total de água tratada pelo DAAE-Araraquara e ETA-Fonte e o volume de resíduo gerado nas descargas dos decantadores e lavagens dos filtros.

\subsubsection{Obtenção e Caracterização do Resíduo da Descarga dos Decantadores}

O resíduo da descarga do decantador foi obtido coletando-se alíquotas em intervalos de 30 segundos na saída do canal que recebe este resíduo (ver Figura 4.10). Estas alíquotas foram misturadas obtendo uma amostra composta que foi submetida a uma caracterização, e posteriormente adicionados à ETE-Piloto. 

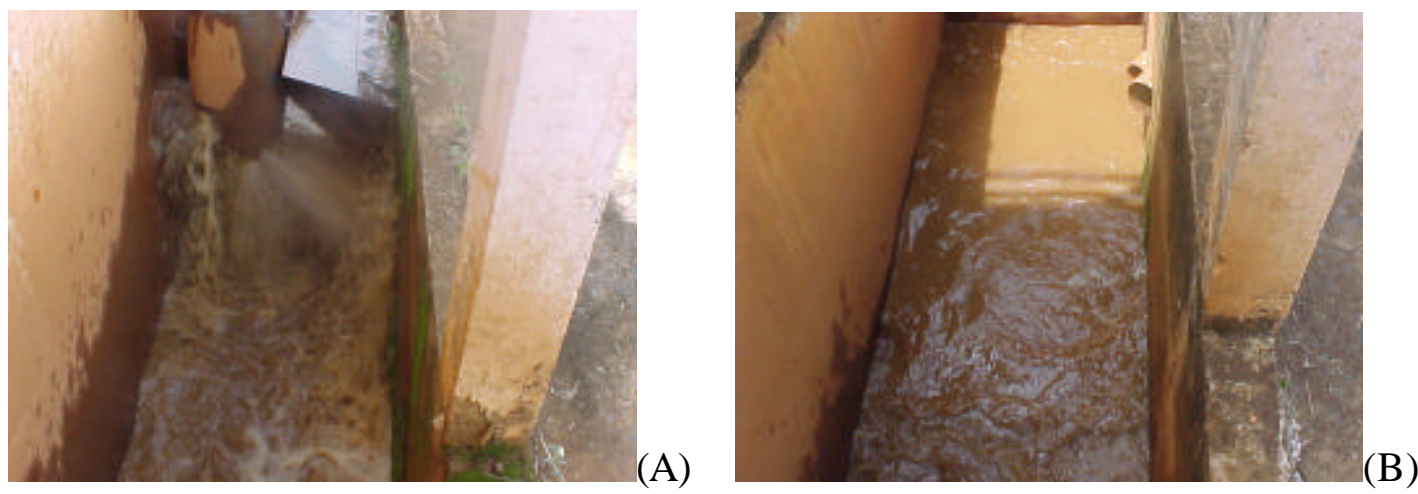

Figura 4.10 - (A) Fotografia durante a descarga; (B) Fotografia da saída do canal que recebe o resíduo das descargas dos decantadores da ETA-Fonte, onde foram coletadas as amostras para dispor na ETE-Piloto.

\subsubsection{Obtenção e Caracterização da Água de Lavagem de Filtro}

As amostras da água de lavagem de filtros foram coletadas, com auxílio de uma bomba submersível instalada no fundo do filtro, onde apresentava uma melhor mistura do resíduo. A vazão da bomba foi controlada por meio de dois registros presentes no final da mangueira, conforme esquema da figura 4.11.
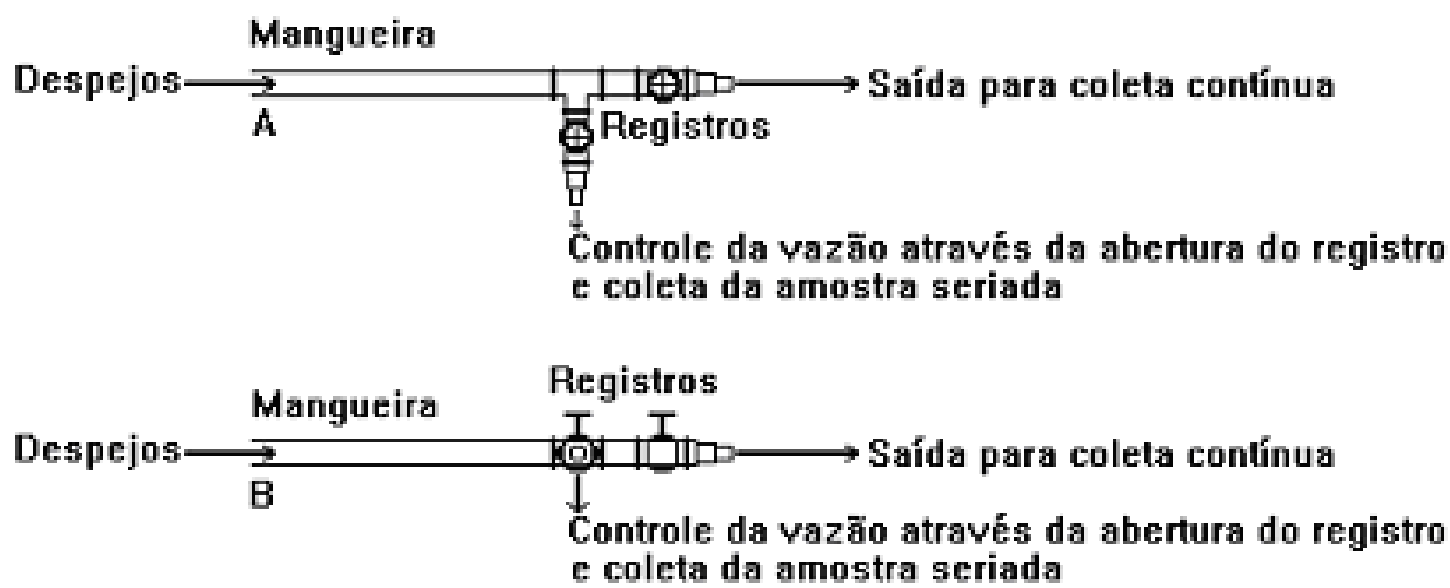

Figura 4.11 - Dispositivo para controle da vazão do despejo coletado pela bomba submersível, durante a lavagem do filtro. A) Planta; B) Vista lateral. 


\subsubsection{Descrição das Instalações em Escala Piloto}

O sistema de tratamento de esgoto em escala piloto, utilizado no experimento, foi composto por dois conjuntos de lagoas (ver figura 4.12), sendo constituído por uma Lagoa de Aeração e uma de Sedimentação, alimentado constantemente, por uma bomba dosadora, com esgoto sanitário coletado diretamente da chegada do esgoto bruto na ETE-Araraquara.

Após operar as ETEs-piloto por alguns dias apenas recebendo esgoto sanitário, iniciou-se a adição de resíduo de ETA em um dos conjuntos. A adição de resíduo foi realizado 6 vezes ao dia.

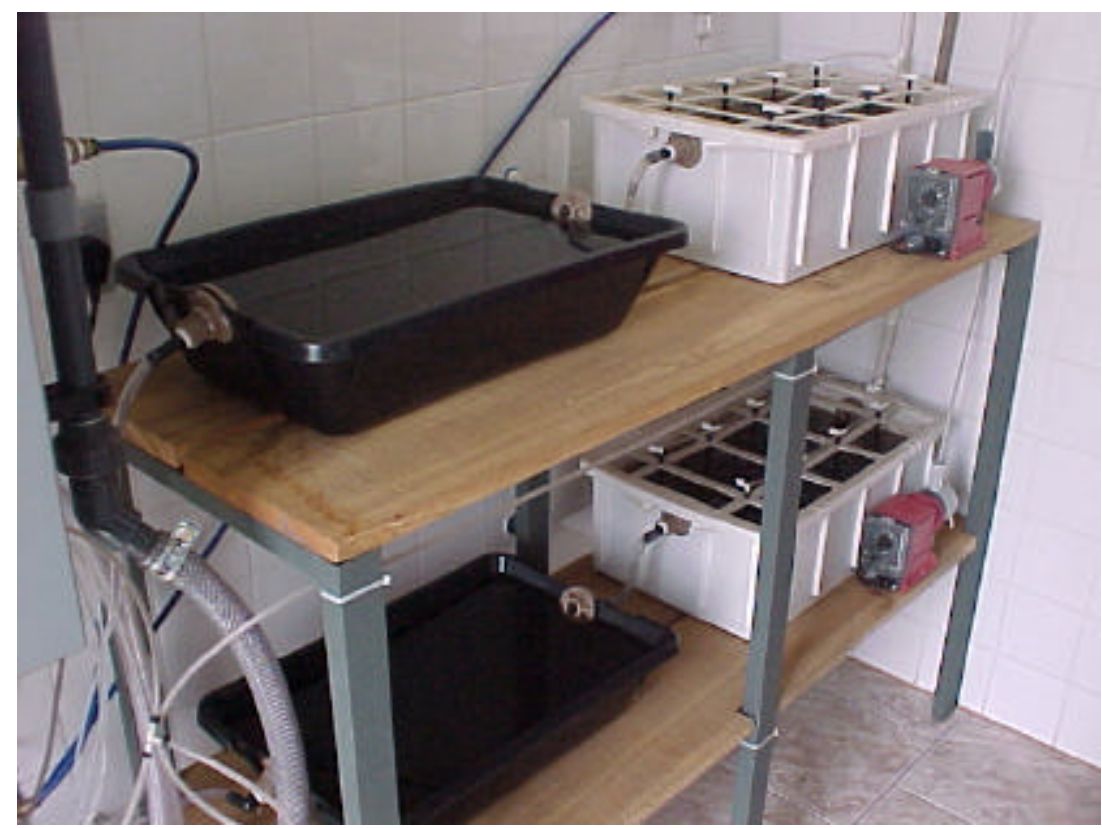

Figura 4.12 - Fotografia dos conjuntos de lagoas em escala piloto, sendo cada um constituído por uma Lagoa de Aeração e uma de Sedimentação.

\subsubsection{Lagoa de Aeração em Escala Piloto}

A Lagoa de Aeração em escala piloto (Figura 4.13) foi composta por um conjunto de 8 difusores de ar, abastecidos por um compressor, fornecendo 1,0 $\mathrm{L} / \mathrm{min}$ a uma pressão de $3,5 \mathrm{kgf} / \mathrm{cm}^{2}$, valor este suficiente para garantir uma concentração de oxigênio dissolvido acima de $1,5 \mathrm{mg} / \mathrm{L}$ de $\mathrm{O}_{2}$ em qualquer ponto da lagoa, medido por um oxímetro. A mistura do licor foi mantida com auxílio de uma moto bomba submersível. 


\section{Dimensões e Características das Lagoas de Aeração em escala piloto:}

$\begin{array}{ll}\text { Comprimento } & =55,0 \mathrm{~cm} \\ \text { Largura } & =35,0 \mathrm{~cm} \\ \text { Profundidade útil } & =15,6 \mathrm{~cm} \\ \text { Volume } & =30,0 \mathrm{~L} \\ \text { Tempo de detenção } & =3,0 \text { dias }\end{array}$

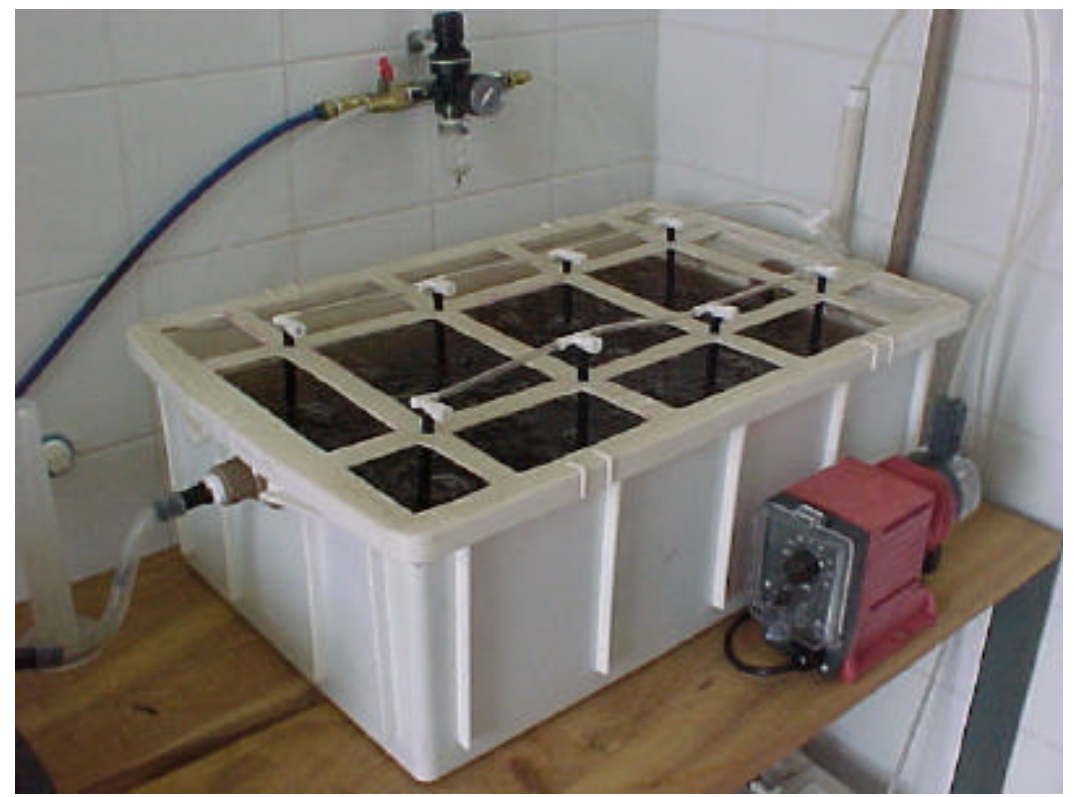

Figura 4.13 - Fotografia da Lagoa de Aeração em escala piloto, composta por 8 difusores de ar e alimentada com esgoto sanitário por uma bomba dosadora.

\subsubsection{Lagoa de Sedimentação em Escala Piloto}

A Lagoa de Sedimentação em escala piloto (ver figura 4.14), foi construída utilizando uma caçamba plástica utilizada por pedreiros, que apresenta características semelhantes a uma lagoa de sedimentação com as paredes laterais inclinadas.

Dimensões e Caracte rísticas das Lagoas de Sedimentação em escala piloto:

Comprimento superficial $=57,0 \mathrm{~cm}$

Largura superficial $\quad=38,0 \mathrm{~cm}$

Profundidade útil $\quad=10,5 \mathrm{~cm}$

Volume

$=10,0 \mathrm{~L}$

Tempo de detenção $\quad=1,5$ dias 


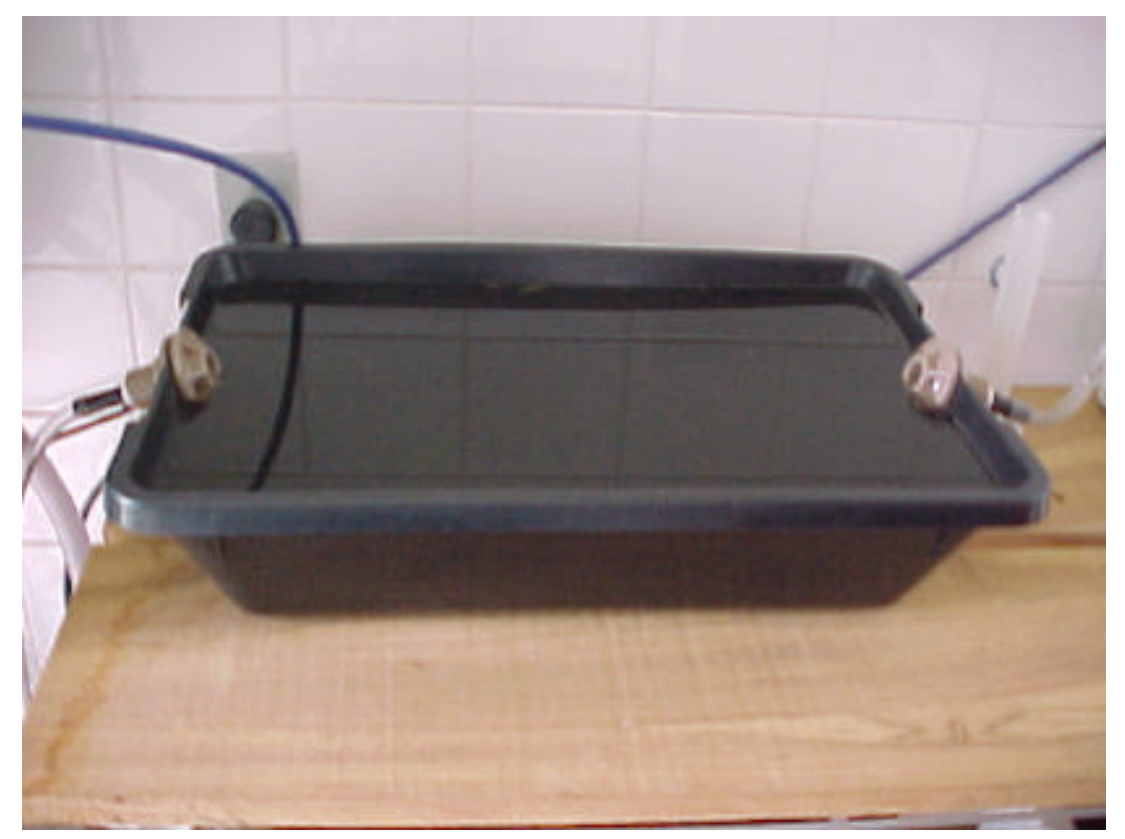

Figura 4.14 - Fotografia da Lagoa de Sedimentação em escala piloto com tempo de detenção de 1,5 dias.

\subsubsection{Descrição do Ensaio em Escala Piloto}

A partida das unidades em escalas piloto foi dada após enchimento com licor misto da lagoa de aeração da ETE-Araraquara.

Rotineiramente foram realizadas leituras de OD no início, meio e final das lagoas de aeração em escala piloto, mantendo um teor superior a 1,5 mg/L.

Durante os primeiros 30 dias de operação dos dois conjuntos de lagoas em escala piloto, recebendo apenas esgoto sanitário com uma vazão de 6,94 mL/min, foram realizadas caracterizações dos afluentes aos sistemas, bem como dos efluentes, seguindo os parâmetros constantes na tabela 4.3. Após 30 dias de operação foram realizados exames microscópicos nos licores mistos das lagoas de aeração, sendo que nesta ocasião iniciou-se a adição de resíduo da ETA-Fonte na entrada da lagoa de aeração piloto 1 .

Durante os 3 meses de operação da ETE-Piloto, após começar a receber resíduo de ETA, foram realizadas caracterizações dos afluentes as ETEs-piloto e dos efluentes na saída das lagoas de sedimentação. No início e final da operação das ETEs-pilotos foram realizados exames microscópicos e determinado a $\mathrm{TCO}_{\mathrm{a}}$ no licor misto das lagoas de aeração. 
No final dos 3 meses de operação a alimentação foi interrompida, sendo o lodo das lagoas de sedimentação removido e caracterizados. Posteriormente, foram realizados ensaios de centrifugação e as tortas resultantes foram submetidas a ensaios de lixiviação e solubilização.

Tabela 4.7 - Parâmetros para caracterização do afluente e efluente da ETE-Piloto.

Parâmetros

\begin{tabular}{|c|}
\hline $\mathrm{DQO}(\mathrm{mg} / \mathrm{L})$ \\
\hline $\mathrm{DBO}(\mathrm{mg} / \mathrm{L})$ \\
\hline Remoção de DQO (\%) \\
\hline Remoção de DBO (\%) \\
\hline $\mathrm{pH}$ \\
\hline Condutividade elétrica elétrica $(\mu \mathrm{s} / \mathrm{cm})$ \\
\hline Sólidos Totais (mg/L) \\
\hline Sólidos Totais Fixos (mg/L) \\
\hline Sólidos Voláteis (mg/L) \\
\hline Sólidos Suspensos Totais (mg/L) \\
\hline Sólidos Suspensos Fixos (mg/L) \\
\hline Sólidos Suspensos Voláteis (mg/L) \\
\hline Sólidos Dissolvidos Totais (mg/L) \\
\hline Sólidos Dissolvidos Fixos (mg/L) \\
\hline Sólidos Dissolvidos Voláteis (mg/L) \\
\hline Sol. Sedimentáveis Cone Imhoff (mL/L) - 1 hora \\
\hline Turbidez (UT) \\
\hline Cor (UC) \\
\hline Cloreto (mg Cl/L) \\
\hline Nitrogênio amoniacal (mg N/L) \\
\hline Nitrato (mg N/L) \\
\hline Nitrito (mg N/L) \\
\hline Nitrogênio Total Kjeldahl (mg N/L) \\
\hline Fosfato Total (mg P/L) \\
\hline Metais (mg/L) \\
\hline
\end{tabular}




\subsection{DESCRIÇÃO DOS ENSAIOS EM LABORATÓRIO}

Nos itens a seguir são descritos os ensaios realizados em laboratório.

\subsubsection{Atividade Metanogênica}

A metodologia utilizada para os testes de atividade metanogênica do lodo primário foi proposta por CARVALHO (1999) e, encontra-se descrita a seguir:

- réplica do ensaio: duplicata;

- temperatura do ensaio: $30^{\circ} \mathrm{C}$ (controlada por termostato);

- volume dos frascos-reator: $620 \mathrm{~mL}$;

- volume útil dos frascos-reator: 300 a $400 \mathrm{~mL}$;

- relações entre as concentrações de sólidos suspensos voláteis do lodo primário e do inóculo igual a 0,5;

- agitação dos frascos-reator: contínua, com auxílio de "Shaker", com 150 rpm;

- concentração de sólidos suspensos voláteis do inóculo presentes nos frascosreator: $9 \mathrm{~g} / \mathrm{L}$;

- redução do meio líquido: borbulhamento com nitrogênio puro (100\%);

- medição do volume de metano produzido nos frascos-reator: através de leitura da pressão interna a de cromatografia gasosa;

- periodicidade das medidas de metano: 2 vezes ao dia. Após estabilização 1 vez ao dia;

- finalização dos testes: 30 dias após a incubação dos frascos;

- cálculo da atividade: através do coeficiente angular da equação da reta de ajuste do trecho da curva de inclinação máxima, obtida quando se plota volumes de metano, em termos de DQO consumida, divididos pela concentração de sólidos suspensos voláteis médio, versus os respectivos intervalos de tempo.

- análises intermediárias: no decorrer do ensaio foram coletadas amostras, em pequenas alíquotas, em intervalos de 10 dias, utilizando para isto seringa munida de agulha. Estas amostras foram submetidas a microscopia óptica, com aumentos de 10 e 40x. 


\subsubsection{Coliformes Totais e Escherichia coli}

A quantificação dos coliformes totais e Escherichia coli foi realizado através da técnica do Substrato Cromogênico Definido, constante no "Standard Methods for the examination of Water and Wastewater" publicado pela APHA (1998), chamado comercialmente Colilert.

\subsubsection{Ovos e Larvas de Helmintos}

Foi adotado o método de Bailenger modificado para quantificação de ovos e larvas de helmintos, sugerido por AYRES \& MARA (1996).

\subsubsection{Microscopia Óptica}

A microscopia óptica foi realizada no Laboratório de Processos Biológicos da EESC - USP. Foi pesquisada a microfauna presente no lodo obtido do ensaio de digestão anaeróbia na primeira fase, e o licor misto das lagoas de aeração na segunda fase com o objetivo de verificar as possíveis interferências que ocorrerão devido a presença de resíduos de ETA.

\subsubsection{Taxa de Consumo de Oxigênio (TCO)}

A TCO foi avaliada através da metodologia proposta por VON SPERLING (1997), descrita a seguir:

- coletar amostra do frasco-reator;

- medir concentração de Oxigênio;

- elevar a concentração de Oxigênio através de forte agitação, manual ou com auxílio de um compressor;

- submeter à agitação suave para impedir sedimentação. Para isso foi utilizado um aparelho Jar test;

- medir concentração de Oxigênio em intervalos de 1 min., até esta se apresentar aproximadamente constante; 
- plotar os dados em gráfico. A taxa de consumo de Oxigênio é a inclinação da linha de melhor ajuste (regressão linear) no gráfico OD x t.

\subsubsection{Velocidade de Sedimentação da Interface}

A velocidade de sedimentação da interface foi determinada utilizando Cone Imhoff, devido a pouca quantidade de sólidos sedimentáveis presentes no licor misto das lagoas de aeração.

\subsubsection{Equipamentos e Materiais}

- Cone Imhoff e cronômetro.

\subsubsection{Procedimento}

Os ensaios para determinação da velocidade de sedimentação do licor misto das lagoas de aeração tiveram o seguinte procedimento:

- uma alíquota de 1,0 L de licor misto da lagoa de aeração em escala piloto era retirada do sistema e colocada dentro do Cone Imhoff, de forma homogeneizada, estabelecendo o ponto inicial e deixando sedimentar. O nível da interface era medido em diversos intervalos de tempo;

- o ensaio era interrompido após 60 minutos de sedimentação;

- os volumes de sólidos sedimentáveis em função do tempo foram plotados em um gráfico.

\subsubsection{Desidratação do Lodo por Centrifugação}

Os resultados dos ensaios por centrifugação foram obtidos assumindo as seguintes hipóteses: 
1. O volume interno do frasco de centrifugação contendo a amostra de lodo era considerado em sistema fechado (sem perda de massa durante o ensaio);

2. Todos os sólidos em suspensão presentes no lodo eram espessados por centrifugação, ou seja, considerou-se desprezível a concentração de sólidos suspensos remanescentes no sobrenadante (líquido clarificado), após centrifugação. Portanto, é válida a expressão (4.2).

$$
S S T_{\text {inicial }}=\frac{M_{t_{\text {inicial }}}}{V_{t}}
$$

Onde:

$\mathrm{SST}_{\text {inicial }}=$ sólidos suspensos totais inicial $(\mathrm{mg} / \mathrm{L})$

$\mathrm{M}_{\mathrm{t} \text { inicial }}=$ massa total inicial de sólidos em suspensão $(\mathrm{mg})$

$\mathrm{V}_{\mathrm{t}}=$ volume total da suspensão $(\mathrm{L})$

Além disso, torna-se válida a expressão (4.3)

$$
S S T_{\text {final }}=\frac{M_{t_{\text {finsl }}}}{V_{c}}
$$

Onde:

$\mathrm{SST}_{\text {final }}=$ sólidos suspensos totais finais $(\mathrm{mg} / \mathrm{L})$

$\mathrm{M}_{\mathrm{t} \text { final }}=$ massa total final de sólidos suspensos presentes na torta resultante após centrifugação $(\mathrm{mg})$

$\mathrm{V}_{\mathrm{c}}=$ volume resultante de torta após centrifugação $(\mathrm{L})$

Considerando o sistema fechado, foi obtido a eq. (4.4).

$$
S S T_{\text {final }}=S S T_{\text {inicial }} \frac{V_{t}}{V_{c}}
$$

Este procedimento permitiu avaliar o grau de adensamento obtido por centrifugação em função de parâmetros operacionais de centrifugação (força centrífuga aplicada ou tipo e dosagem de polímero utilizado). 


\subsubsection{Cálculo da Aceleração Centrífuga Aplicada no Equipamento de Laboratório}

A aceleração da centrífuga foi calculada através da eq. (4.5)

$$
a_{c}=R \cdot W^{2}
$$

Onde:

$a_{c}=$ aceleração centrífuga $\left(\mathrm{m} / \mathrm{s}^{2}\right)$

$\mathrm{R}=$ raio do centro de rotação até a extremidade do tubo. Para a centrífuga utilizada foi de $0,185 \mathrm{~m}$.

$\mathrm{W}=$ velocidade de centrifugação $(\mathrm{m} / \mathrm{s})$

A velocidade de centrifugação (W) foi calculada através da eq. (4.6).

$$
W=\frac{2 \pi \cdot N}{60}
$$

Onde:

$\mathrm{N}$ = rotação da centrífuga (rpm). Para a centrífuga utilizada foi de $2200 \mathrm{rpm}$.

Neste experimento, a aceleração era considerada em termos dimensionais, isto é, sob a eq. (4.7).

$$
Z=\frac{a_{c}}{g}
$$

Onde:

$\mathrm{g}=$ aceleração gravitacional $\left(\mathrm{m} / \mathrm{s}^{2}\right)=9,81 \mathrm{~m} / \mathrm{s}^{2}$

O manual da centrífuga utilizada no experimento fornece uma fórmula para ser calculada a força centrífuga relativa (FCR)

$$
\begin{aligned}
& F C R=0,00001118 *{ }^{*}{ }^{*} N^{2} \\
& F C R=g
\end{aligned}
$$

Onde: 


$$
\begin{aligned}
& R=\text { raio do centro de rotação até a extremidade do tubo }(\mathrm{cm}) \\
& \mathrm{N}=\text { rotação da centrífuga }(\mathrm{rpm}) .
\end{aligned}
$$

Neste ensaio em bancada foi utilizado

- $\mathrm{FCR}=1000 \mathrm{~g}$

- $Z=9810$

\subsubsection{Equipame ntos e Materiais}

- Centrífuga de bancada modelo 215 da marca FANEM;

- tubo graduado de fundo cônico com volume de $15 \mathrm{~mL}$;

- cronômetro;

- solução de polieletrólito de caráter catiônico.

\subsection{Características do Polieletrólito}

O polieletrólito utilizado foi obtido na SABESP da cidade de Franca-SP, sendo empregado para desaguamento em centrífuga e filtro prensa apresentando a seguinte especificação técnica:

- Polieletrólito catiônico em pó;

- Caráter lônico

- catiônico de alto peso molecular;

- Densidade

- $0,85 \mathrm{~g} / \mathrm{cm}^{3}$;

- Base

- acrilamida;

- Viscosidade

- $5,0 \mathrm{~g} / \mathrm{L}=750 \mathrm{CPS}$;

- $2,5 \mathrm{~g} / \mathrm{L}=300 \mathrm{CPS}$;

- $1,0 \mathrm{~g} / \mathrm{L}=90$ CPS;

- Aparência

- pó branco granulado; 


\subsubsection{Procedimento}

Para o ensaio de centrifugação foi adotado o seguinte procedimento:

- $10 \mathrm{~mL}$ do lodo das lagoas de sedimentação eram distribuídos em cada tubo de fundo cônico;

- Em seguida eram acrescentadas diferentes dosagens de polieletrólito variando as relações massa $(\mathrm{g})$ de polieletrólito por massa $(\mathrm{kg})$ de SST;

- Os tubos eram agitados vigorosamente e colocados na centrífuga sendo submetidos a aproximadamente $1000 \mathrm{~g}$.

- A centrifugação era interrompida em intervalos de tempo para medir o volume de lodo no fundo do tubos;

- Após 60 minutos a centrifugação era interrompida e o sobrenadante e a torta de lodo foram coletados e caracterizados conforme descritos a seguir:

\subsection{Coleta e Caracterização do Sobrenadante Após Centrifugação}

Após centrifugação o sobrenadante era coletado através de pipetagem, desprezando-se aproximadamente $0,5 \mathrm{~cm}$ do líquido próximo a interface torta/líquido, de forma a evitar o arraste de sólidos presentes na torta.

O sobrenadante foi caracterizado utilizando os parâmetros DQO, turbidez; sólidos suspensos totais, fixos e voláteis.

\subsection{Coleta e Caracterização da Torta de Lodo Após Centrifugação}

A remoção da torta era realizada com auxílio de uma espátula, após remover o restante do sobrenadante, vertendo-se o tubo, além de desprezar aproximadamente 2,0 $\mathrm{mm}$ da torta próxima à interface.

A torta resultante do ensaio de centrifugação foi caracterizada quanto aos metais presentes e por meio do ensaio de lixiviação e solubilização, visando uma possível disposição em aterro sanitário. 


\subsubsection{Ensaio de Lixiviação}

Os ensaios de Lixiviação foram realizados de acordo com a norma NBR 10005 da ABNT - Associação Brasileira de Normas Técnicas. Os parâmetros pesquisados nos extratos obtidos nos testes de lixiviação foram retirados da NBR 10004/1987 Anexo G Listagem nº 7 - Concentração - onde estão os limites máximos permitidos (ver tabela 4.8).

Tabela 4.8 - Limite máximo permitido dos poluentes presentes no extrato obtido no ensaio de Lixiviação.

\begin{tabular}{cc}
\hline Poluente & $\begin{array}{c}\text { Limite máximo no extrato } \\
(\mathbf{m g} / \mathbf{L})\end{array}$ \\
\hline Arsênio & 5,0 \\
Bário & 100,0 \\
Cádmio & 0,05 \\
Chumbo & 5,0 \\
Cromo Total & 5,0 \\
Fluoreto & 150,0 \\
Mercúrio & 0,1 \\
Prata & 5,0 \\
Selênio & 1,0 \\
Aldrin & 0,003 \\
DDT & 0,1 \\
Dieldrin & 0,003 \\
Endrin & 0,02 \\
Epóxi-heptacloro & 0,01 \\
Heptacloro & 0,01 \\
Hexaclorobenzeno & 0,001 \\
Lindano & 0,3 \\
Pentaclorofenol & 1,0 \\
\hline
\end{tabular}




\subsubsection{Ensaios de Solubilização}

Os ensaios de Solubilização foram realizados de acordo com a norma NBR 10006 da ABNT - Associação Brasileira de Normas Técnicas. Os parâmetros pesquisados nos extratos obtidos nos testes de solubilização foram retirados da NBR 10004/1987 Anexo H Listagem no 8 - Padrões para teste de solubilização onde estão os limites máximos permitidos (ver tabela 4.9)

Tabela 4.9 - Limite máximo permitido dos poluentes presentes no extrato obtido no ensaio de Solubilização.

\begin{tabular}{cc} 
Poluentes & $\begin{array}{c}\text { Limite máximo no extrato } \\
(\mathbf{m g} / \mathbf{L})\end{array}$ \\
\hline Arsênio & 0,05 \\
Bário & 1,0 \\
Cádmio & 0,005 \\
Chumbo & 0,05 \\
Cianeto & 0,1 \\
Fenol & 0,001 \\
Nitrato & 10,0 \\
Cromo Total & 0,05 \\
Fluoreto & 1,5 \\
Mercúrio & 0,001 \\
Prata & 0,05 \\
Selênio & 0,01 \\
Aldrin & $3,0 \times 10^{-5}$ \\
DDT & $1,0 \times 10^{-4}$ \\
Dieldrin & $3,0 \times 10^{-4}$ \\
Endrin & $2,0 \times 10^{-4}$ \\
Epóxi-heptacloro & $1,0 \times 10^{-4}$ \\
Heptacloro & $1,0 \times 10^{-4}$ \\
Hexaclorobenzeno & $1,0 \times 10^{-4}$ \\
Lindano & $3,0 \times 10^{-4}$ \\
Pentaclorofenol & 0,01 \\
Alumínio & 0,2 \\
Cloreto & 250,0 \\
Cobre & 1,0 \\
Dureza & 500,0 \\
Ferro & 0,3 \\
Manganês & 0,1 \\
Sódio & 200,0 \\
Surfactantes & 0,2 \\
Sulfato & 400,0 \\
Zinco & 5,0 \\
\hline & \\
\hline &
\end{tabular}




\subsubsection{Pesquisa de Metais}

A pesquisa de metais seguiu a metodologia descrita no "Standard Methods for the examination of Water and Wastewater" publicado pela APHA (1998), sendo que as amostras foram digeridas por via úmida com ácido nítrico e clorídrico e as leituras foram realizadas pelo método Absorção Atômica por chama de ar acetileno.

\subsubsection{Resistência Específica à Filtração}

O teste da resistência específica à filtração foi realizado utilizando $25 \mathrm{~mL}$ do material sedimentado, volume disponível resultante de cada ensaio, devido a dificuldade encontrada para obtenção de um volume maior do material. O teste foi adaptado com base no teste do tempo de filtração constante no "Standard Methods for the examination of Water and Wastewater" publicado pela APHA (1998), no qual são utilizados volumes menores.

Os equipamentos e materiais utilizados no teste da Resistência Específica estão esquematizados na figura 4.15 .

\subsubsection{Equipamentos e Materiais}

- funil de Buchner $n^{\circ}$ 2;

- bomba que forneça um vácuo de $380 \mathrm{~mm} \mathrm{Hg}$;

- cronômetro;

- medidor de vácuo (manômetro);

- proveta graduada de $25 \mathrm{~mL}$ com dispositivo para tomada de vácuo;

- papel de filtro Whatman no 42;

- anel em borracha vedante para funil de Buchner encaixar na proveta;

- mangueira para ligar a proveta a bomba;

\subsubsection{Procedimento}

Para o teste da resistência específica foi adotado o seguinte procedimento: 
- O papel de filtro Whatman 42 era recortado de tamanho igual ao diâmetro interno do funil de Buchner e em seguida colocado no funil de Buchner e umedecido com água destilada;

- em seguida era aplicada uma pressão de sucção para ocorrer a aderência do papel ao funil e para remover o excesso de água;

- uma certa quantidade fixada do material sedimentado, ou seja $25 \mathrm{~mL}$, era colocado sobre o papel de filtro e aplicada nova sucção no sistema de $380 \mathrm{~mm}$ de $\mathrm{Hg}$ registrando-se, em função do tempo, o volume do filtrado. Os valores de $\mathbf{t} / \mathbf{v}$ em função de $\mathbf{v}$ foram plotados em gráfico, obtendo-se o valor de $\mathbf{b}$, sendo utilizado na equação para calcular a resistência específica. Após o término da filtração ou queda do vácuo, o ensaio era encerrado.

- Devido à dificuldade em se medir as concentrações de sólidos retidos no papel de filtro, pois parte do material era retido nas paredes do funil de Buchner, foram utilizados nos cálculos para determinar a resistência específica os valores de SST obtidos na caracterização do lodo.

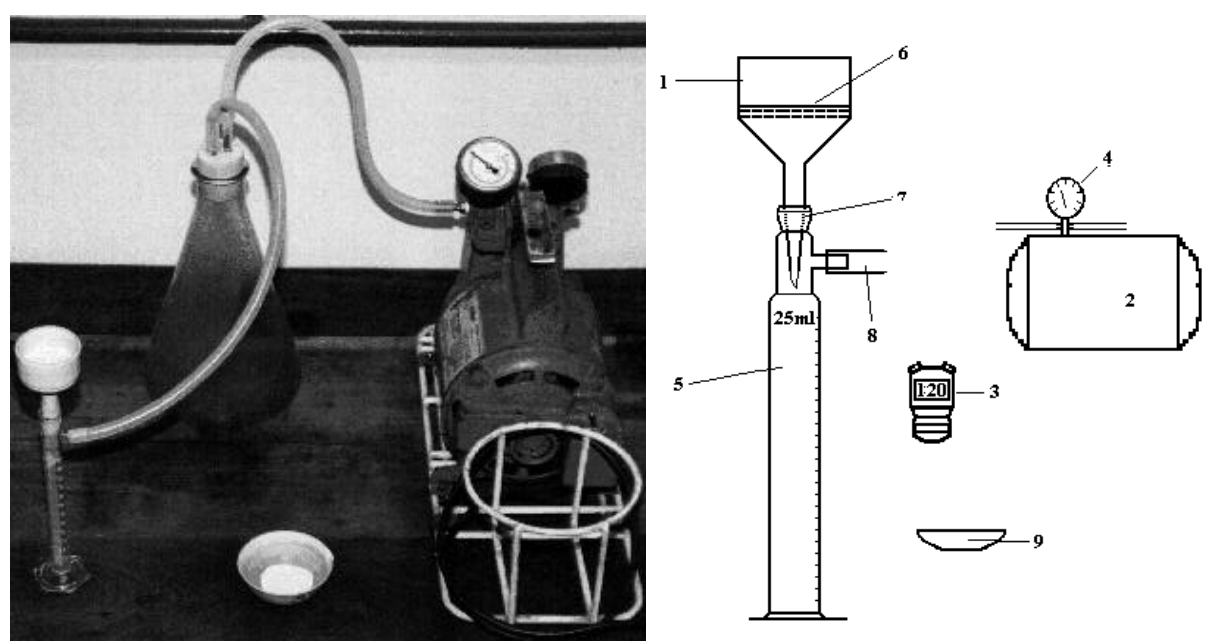

Figura 4.15 - Fotografia a direita mostra a aparelhagem utilizada para determinação da resistência específica. No esquema à esquerda estão detalhados os equipamentos e materiais utilizados no teste da resistência específica. 1 - funil de Buchner no 2; 2 - bomba de vácuo; 3 - cronômetro; 4 - manômetro; 5 - proveta graduada de $25 \mathrm{~mL}$ com dispositivo para tomada de vácuo; 6 - papel de filtro Whatman nீ 42; 7 - anel em borracha vedante para funil de Buchner encaixar na proveta; 8 - mangueira para ligar a proveta a bomba; e 9 - cadinho de porcelana. 


\subsubsection{Análises e Exames Laboratoriais}

As análises e exames laboratoriais realizadas na pesquisa estão de acordo com o "Standard Methods for the examination of Water and Wastewater" publicado pela APHA (1998), exceto a análise de nitrato que segue a norma L5.137 da CETESB. Os métodos referentes às análises e exames empregados na parte experimental estão descritos na tabela 4.10.

Tabela 4.10 - Métodos e Equipamentos empregados para determinação dos parâmetros físico-químicos e bacteriológicos utilizados na parte experimental. Com exceção da análise de Nitrato, os demais parâmetros seguem os métodos contidos no "Standard Methods for the examination of Water and Wastewater" publicado pela APHA (1998).

\begin{tabular}{|c|c|c|c|}
\hline PARÂMETROS & № MÉTODO & EQUIPAMENTOS & MARCA \\
\hline $\mathrm{DBO}(\mathrm{mg} / \mathrm{L})$ & $5210 \mathrm{D}$ & $\begin{array}{l}\text { Incubadora DBO } \\
\text { Bureta digital }\end{array}$ & $\begin{array}{l}\text { Quimis } \\
\text { BRAND }\end{array}$ \\
\hline $\mathrm{DQO}(\mathrm{mg} / \mathrm{L})$ & $5220 \mathrm{~B}$ & $\begin{array}{c}\text { Digestor } \\
\text { espectrofotômetro }\end{array}$ & $\begin{array}{l}\text { Hach } \\
\text { Hach }\end{array}$ \\
\hline $\mathrm{pH}$ & $4500-\mathrm{H}^{+} \mathrm{B}$ & phmetro mod. DM 20 & Digimed \\
\hline Condutividade elétrica $(\mu \mathrm{s} / \mathrm{cm})$ & $2520 \mathrm{~B}$ & $\begin{array}{c}\text { Condutivímetro } \\
\text { mod.QI405B }\end{array}$ & Quimis \\
\hline Sólidos Totais $(\mathrm{mg} / \mathrm{L})$ & $2540 \mathrm{~B}$ & Estufa mod. $315 \mathrm{SE}$ & Fanem \\
\hline Sólidos Fixos $(\mathrm{mg} / \mathrm{L})$ & $2540 \mathrm{E}$ & - & - \\
\hline Sólidos Voláteis (mg/L) & $2540 \mathrm{E}$ & Mufla & Fornitec \\
\hline Sólidos Suspensos Totais (mg/L) & $2540 \mathrm{D}$ & Estufa mod. $315 \mathrm{SE}$ & Fanem \\
\hline Sólidos Suspensos Fixos (mg/L) & $2540 \mathrm{E}$ & - & - \\
\hline Sólidos Suspensos Voláteis (mg/L) & $2540 \mathrm{E}$ & Mufla & Fornitec \\
\hline Sólidos Dissolvidos Totais (mg/L) & ST-SST & - & - \\
\hline Sólidos Dissolvidos Fixos (mg/L) & SF - SSF & - & - \\
\hline Sólidos Dissolvidos Voláteis (mg/L) & SV - SSV & - & - \\
\hline $\begin{array}{l}\text { Sólidos Sedimentáveis - Cone } \\
\text { Imhoff (mL/L) }\end{array}$ & $2540 \mathrm{~F}$ & Cone de plástico & - \\
\hline Cloreto $(\mathrm{mg} \mathrm{Cl} / \mathrm{L})$ & $4500-\mathrm{Cl}^{-} \mathrm{B}$ & Vidraria & - \\
\hline Nitrato (mgN/L) & $\begin{array}{c}\text { L5.137 } \\
\text { (CETESB) }\end{array}$ & $\begin{array}{c}\text { Banho Maria } \\
\text { espectrofotômetro DR } 2010\end{array}$ & $\begin{array}{c}\text { Marconi } \\
\text { Hach }\end{array}$ \\
\hline Nitrito (mg N/L) & $4500-\mathrm{NO}_{2}^{-} \mathrm{B}$ & espectrofotômetro DR 2010 & Hach \\
\hline Nitrogênio amoniacal (mg N/L) & $4500-\mathrm{NH}_{3} \mathrm{~F}$ & $\begin{array}{c}\text { Destilador } \\
\text { espectrofotômetro DR } 2010\end{array}$ & $\begin{array}{c}\text { Marconi } \\
\text { Hach }\end{array}$ \\
\hline Nitrogênio Total Kjeldahl (mg N/L) & $4500-N_{\text {org }} B$ & $\begin{array}{c}\text { Digestor } \\
\text { Destilador }\end{array}$ & $\begin{array}{l}\text { Marconi } \\
\text { Marconi }\end{array}$ \\
\hline Coliformes Totais (NMP/100mL) & $9223 \mathrm{~B}$ & $\begin{array}{l}\text { Seladora e lâmpada UV } \\
\text { Incubadora ECB } 1.3\end{array}$ & $\begin{array}{c}\text { Idexx } \\
\text { Odontobrás }\end{array}$ \\
\hline Escherichia coli (NMP/100mL) & $9223 \mathrm{~B}$ & $\begin{array}{l}\text { Seladora e lâmpada UV } \\
\text { Incubadora ECB } 1.3\end{array}$ & $\begin{array}{c}\text { Idexx } \\
\text { Odontobrás }\end{array}$ \\
\hline
\end{tabular}




\section{RESULTADOS E DISCUSSÃO}

Os resultados obtidos estão apresentados em duas fases, descritas a seguir:

\subsection{PRIMEIRA FASE}

\subsubsection{Dados Operacionais}

O levantamento de dados relativos ao funcionamento da ETA-SC foi realizado através da análise dos relatórios dos registros operacionais de janeiro a dezembro de 1999. Neste período a ETA-SC produziu 1.121.522,29 $\mathrm{m}^{3} / \mathrm{mês}$ de água, sendo que o volume gerado na limpeza dos decantadores e lavagem dos filtros foram, respectivamente, de $1.375,00 \mathrm{~m}^{3} / \mathrm{mês}$ e $56.076,12 \mathrm{~m}^{3} / \mathrm{mês}$, representando $0,12 \%$ e $5,00 \%$.

Na figura 5.1 pode ser observada a freqüência da realização das limpezas dos decantadores da ETA-SC no ano de 1999. Os decantadores 1 e 3 foram limpos quatro vezes cada um, e o decantador 2 apenas três vezes. O volume de resíduo gerado em cada limpeza foi de aproximadamente $1500 \mathrm{~m}^{3}$, totalizando $16.500,00$ $\mathrm{m}^{3} / \mathrm{ano}$, o que representa uma média de $1.375,00 \mathrm{~m}^{3} / \mathrm{mês}$. A limpeza é feita de forma manual através da abertura de registros situados no fundo, e superficialmente com auxílio de mangueiras de alta pressão.

A filtração descendente é a tecnologia de filtração empregada na ETASC onde a lavagem é realizada apenas com água no sentido ascensional, gerando $56.076,12 \mathrm{~m}^{3} /$ mês de resíduo.

Foi considerado que o volume de água fornecido pela ETASC abastecerá uma população que produzirá $80 \%$ deste volume em forma de esgoto. Este foi 0 
volume utilizado na simulação, em escala piloto, de um decantador primário que recebeu resíduos da ETASC. O volume de esgoto gerado, considerado, foi de $897.218,83 \mathrm{~m}^{3} / \mathrm{mês}$.

\subsubsection{Resíduo da Limpeza do Decantador}

O resíduo da limpeza do decantador foi coletado junto ao canal que antecede a cortina de distribuição para os decantadores, local onde têm-se acúmulo de sólidos. A partir desta amostra foram preparadas, para cada ensaio, três amostras com diferentes concentrações de SST. Estas amostras foram caracterizadas, e os resultados encontram-se na tabela 5.1 .

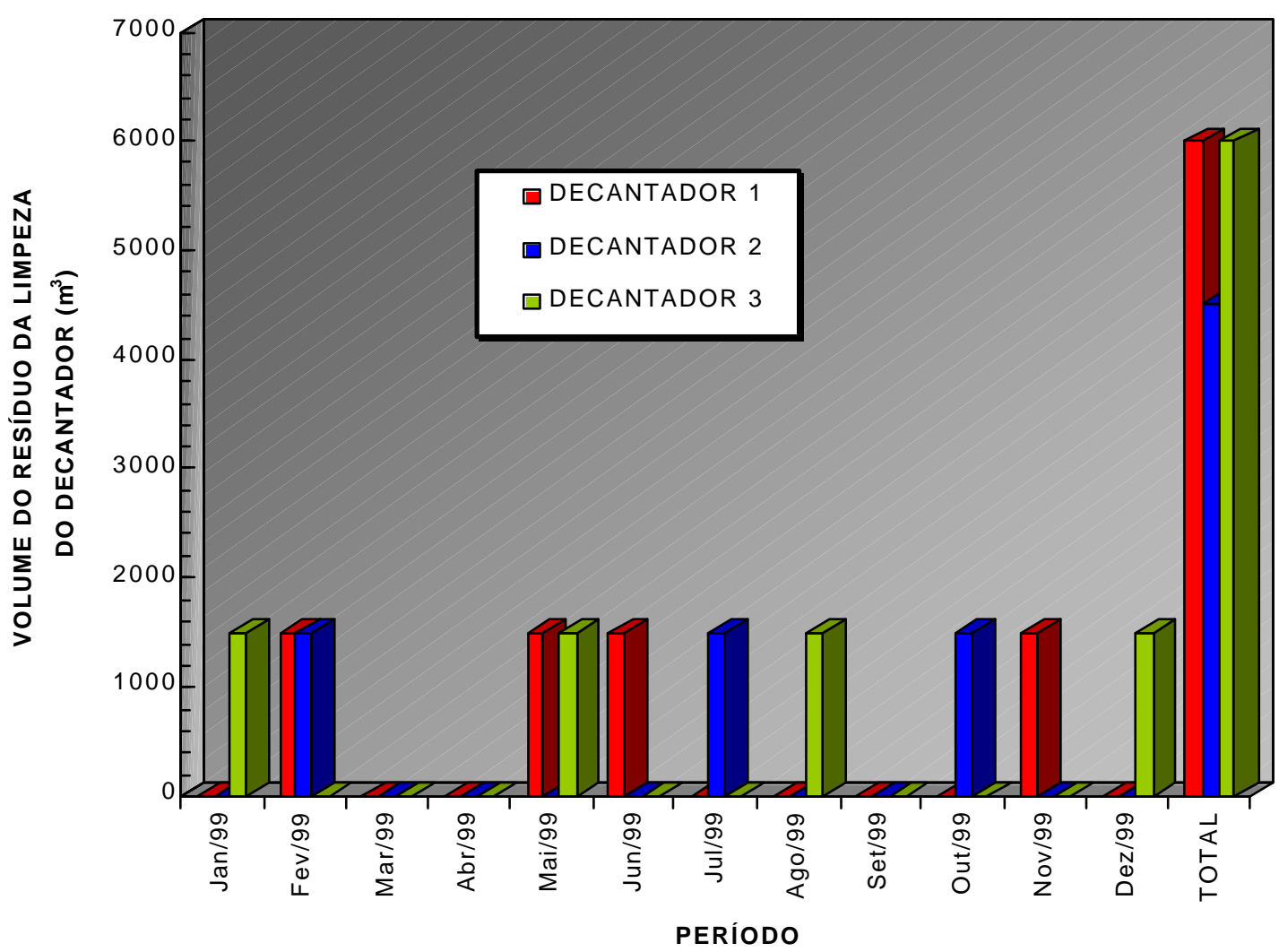

Figura 5.1 - Freqüência da limpeza dos decantadores e volume de resíduo gerado na ETA-SC durante o ano de 1999. 
Tabela 5.1 - Caracterização dos resíduos da limpeza do decantador, utilizados nos ensaios de sedimentação.

\begin{tabular}{lccc}
\hline \multirow{2}{*}{ PARÂMETROS } & \multicolumn{3}{c}{ AMOSTRAS } \\
\cline { 2 - 4 } & 1 & 2 & 3 \\
\hline Turbidez (UT) & 576 & 1836 & 3565 \\
SST (g/L) & 0,88 & 2,71 & 5,24 \\
SST Fixos (g/L) & 0,70 & 2,16 & 4,20 \\
SST Voláteis (g/L) & 0,18 & 0,55 & 1,04 \\
pH & 6,74 & 6,70 & 6,71 \\
DQO (mg/L) & 268 & 1048 & 962 \\
\hline
\end{tabular}

\subsubsection{Resíduo da Lavagem do Filtro - Água de Lavagem de Filtro}

A amostra de água de lavagem de filtro foi obtida através de coleta durante a lavagem de filtro na ETA-SC. Os resultados da caracterização encontram-se na tabela 5.2.

Tabela 5.2 - Caracterização da amostra de água de lavagem de filtro utilizada no ensaio de sedimentação.

\begin{tabular}{lc}
\hline \multicolumn{1}{c}{ PARÂMETROS } & ÁGUA DE LAVAGEM DE FILTRO \\
\hline Turbidez (UT) & 172 \\
SST (mg/L) & 230 \\
SST Fixos (mg/L) & 180 \\
SST Voláteis (mg/L) & 50 \\
pH & 7,3 \\
DQO (mg/L) & 62 \\
\hline
\end{tabular}

\subsubsection{Amostra de Estudo}

As amostras utilizadas nos ensaios de sedimentação nas colunas foram preparadas com misturas diferentes entre o resíduo da lavagem do filtro e da limpeza do decantador. Estas amostras foram caracterizadas e os resultados encontram-se na tabela 5.3. 
Tabela 5.3 - Caracterização dos resíduos utilizados nos ensaios de sedimentação.

\begin{tabular}{lccc}
\hline \multirow{2}{*}{ PARÂMETROS } & \multicolumn{3}{c}{ COLUNAS TESTES } \\
\cline { 2 - 4 } & 1 & 2 & 3 \\
\hline Turbidez (UT) & 260 & 477 & 745 \\
pH & 6,9 & 6,9 & 6,9 \\
SST (g/L) & 0,365 & 0,723 & 1,227 \\
SST Fixos (g/L) & 0,286 & 0,574 & 0,980 \\
SST Voláteis (g/L) & 0,079 & 0,149 & 0,247 \\
DQO (mg/L) & 78 & 263 & 197 \\
\hline
\end{tabular}

\subsubsection{Ensaio de Sedimentação}

Visando simular os possíveis efeitos produzidos em um decantador primário de uma ETE foi realizada uma bateria de ensaios em colunas de sedimentação, sendo uma coluna controle, apenas com esgoto sanitário, e três colunas que receberam, além de esgoto sanitário, amostras dos resíduos da ETA-SC constituído por resíduos da lavagem de filtro e da limpeza de decantador.

As amostras utilizadas neste ensaio foram preparadas com volumes de resíduo de ETA constantes, sendo constituído por 19,89\% de resíduo da limpeza de decantador com concentrações de SST da ordem de 1, 3 e $5 \mathrm{~g} / \mathrm{L}$ e 80,11\% de água de lavagem de filtro, com concentração de SST de $230 \mathrm{mg} / \mathrm{L}$. Na tabela 5.4 estão os volumes de esgoto sanitário, bem como de resíduo de ETA, utilizados no ensaio de sedimentação, além da relação SST do resíduo e esgoto sanitário.

Tabela 5.4 - Volume do esgoto sanitário e da amostra de resíduo de ETA utilizados no ensaio de sedimentação.

\begin{tabular}{|c|c|c|c|c|}
\hline \multirow[t]{2}{*}{ RESÍDUO } & $\begin{array}{c}\text { Coluna } \\
\text { Controle }\end{array}$ & $\begin{array}{c}\text { Coluna } \\
1 \\
\end{array}$ & $\begin{array}{c}\text { Coluna } \\
2 \\
\end{array}$ & $\begin{array}{c}\text { Coluna } \\
3 \\
\end{array}$ \\
\hline & Volume (\%) & Volume (\%) & Volume (\%) & Volume (\%) \\
\hline ESGOTO SANITÁRIO & 100 & 92,76 & 92,76 & 92,76 \\
\hline RESÍDUO DA ETA-SC & 0 & 7,24 & 7,24 & 7,24 \\
\hline $\mathrm{SST}_{\text {residuo ETA }} / \mathrm{SSV}_{\text {Esgoto Sanitário }}(\mathrm{mg} / \mathrm{L}$ ) & 0 & 28,48 & 56,43 & 95,77 \\
\hline
\end{tabular}

Durante o ensaio de sedimentação foram coletadas amostras em intervalos de 20 minutos sendo medidos as concentrações de SST, cujos resultados estão presentes na tabela 5.5, e nas figuras 5.2, 5.3 e 5.4. No início do ensaio, as amostras apresentaram concentrações de SST maiores à medida que o resíduo de 
ETA, adicionado às colunas, foram maiores. No entanto, no final do ensaio, as amostras com menores teores de SST, foram as provenientes das colunas onde foram adicionadas maiores quantidades de resíduos de ETA.

Tabela 5.5 - Concentração de SST em mg/L, medidos nos 3 pontos de coletas de cada coluna em intervalos de 20 minutos até 120 minutos de sedimentação.

\begin{tabular}{ccccccccccccc}
\hline Tempo & \multicolumn{3}{c}{ Coluna Controle } & \multicolumn{3}{c}{ Coluna 1 } & \multicolumn{3}{c}{ Coluna 2 } & \multicolumn{3}{c}{ Coluna 3 } \\
\cline { 2 - 11 } (min.) & ponto 1 & ponto 2 & ponto 3 & ponto 1 & ponto 2 & ponto 3 & ponto 1 & ponto 2 & ponto 3 & ponto 1 & ponto 2 & ponto 3 \\
\hline 0 & 137 & 137 & 137 & 167 & 167 & 167 & 203 & 203 & 203 & 227 & 227 & 227 \\
20 & 128 & 136 & 118 & 156 & 154 & 148 & 170 & 176 & 166 & 178 & 176 & 160 \\
40 & 134 & 136 & 130 & 156 & 148 & 144 & 146 & 140 & 134 & 130 & 140 & 110 \\
60 & 132 & 128 & 124 & 138 & 136 & 130 & 126 & 118 & 110 & 112 & 112 & 110 \\
80 & 130 & 128 & 126 & 146 & 138 & 132 & 124 & 116 & 110 & 128 & 118 & 114 \\
100 & 134 & 124 & 122 & 124 & 124 & 114 & 114 & 114 & 112 & 114 & 112 & 106 \\
120 & 132 & 132 & 120 & 130 & 122 & 104 & 108 & 108 & 106 & 102 & 98 & 90 \\
\hline
\end{tabular}

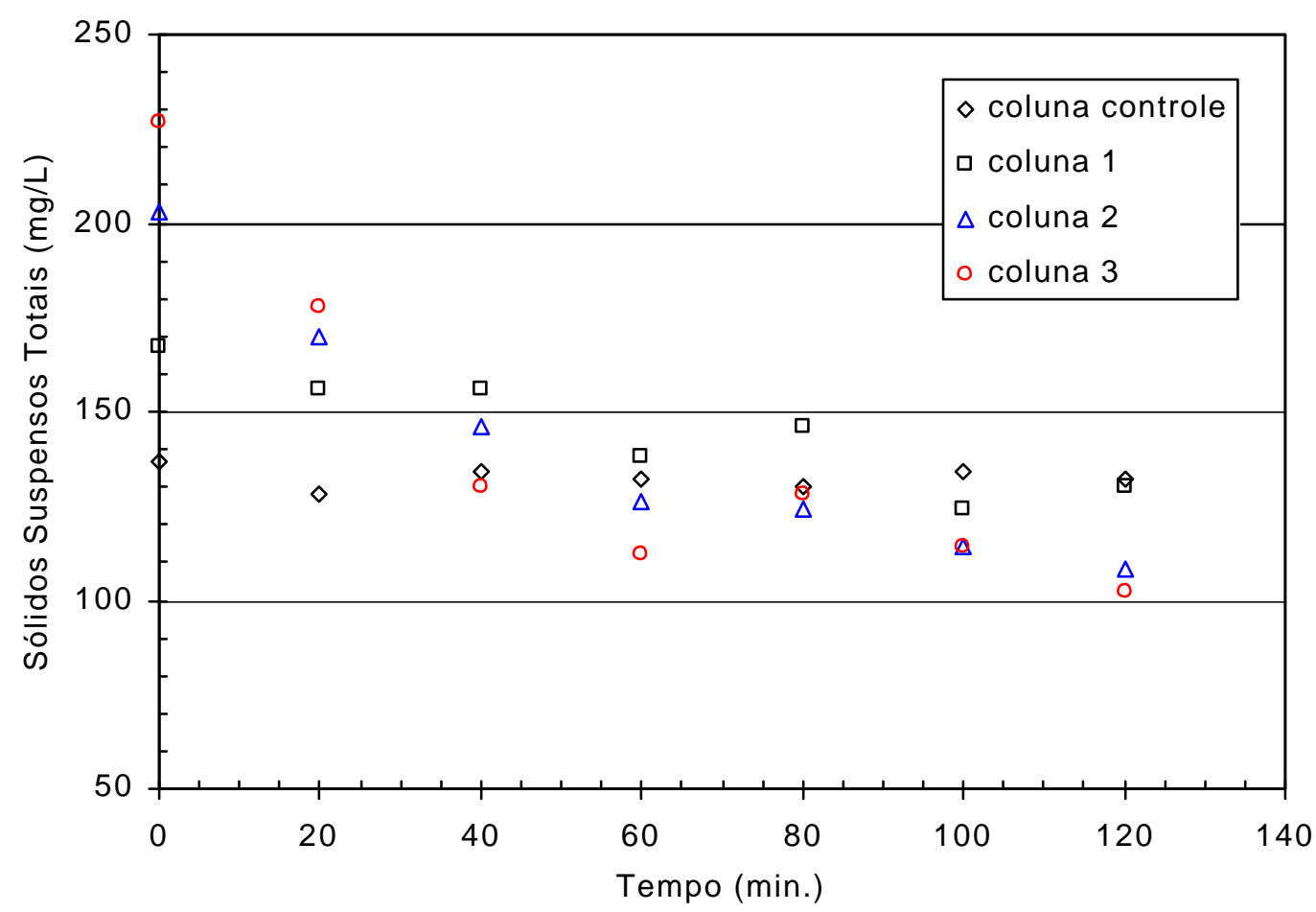

Figura 5.2 - Concentração de SST medidos nas amostras obtidas, em intervalos de 20 minutos, no ponto de coleta 1 de todas colunas da bateria. 


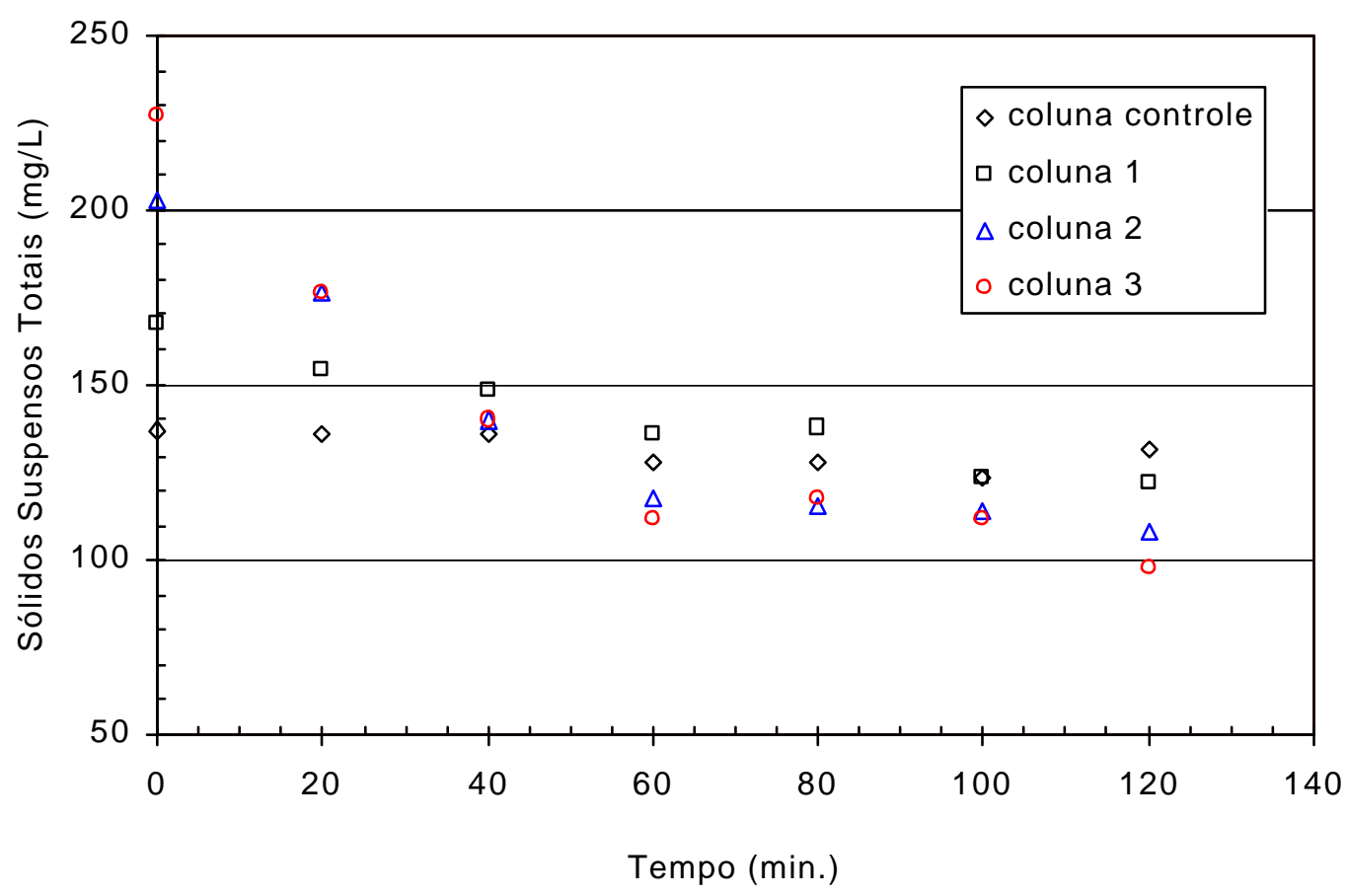

Figura 5.3 - Concentração de SST medidos nas amostras obtidas, em intervalos de 20 minutos, no ponto de coleta 2 de todas colunas da bateria.

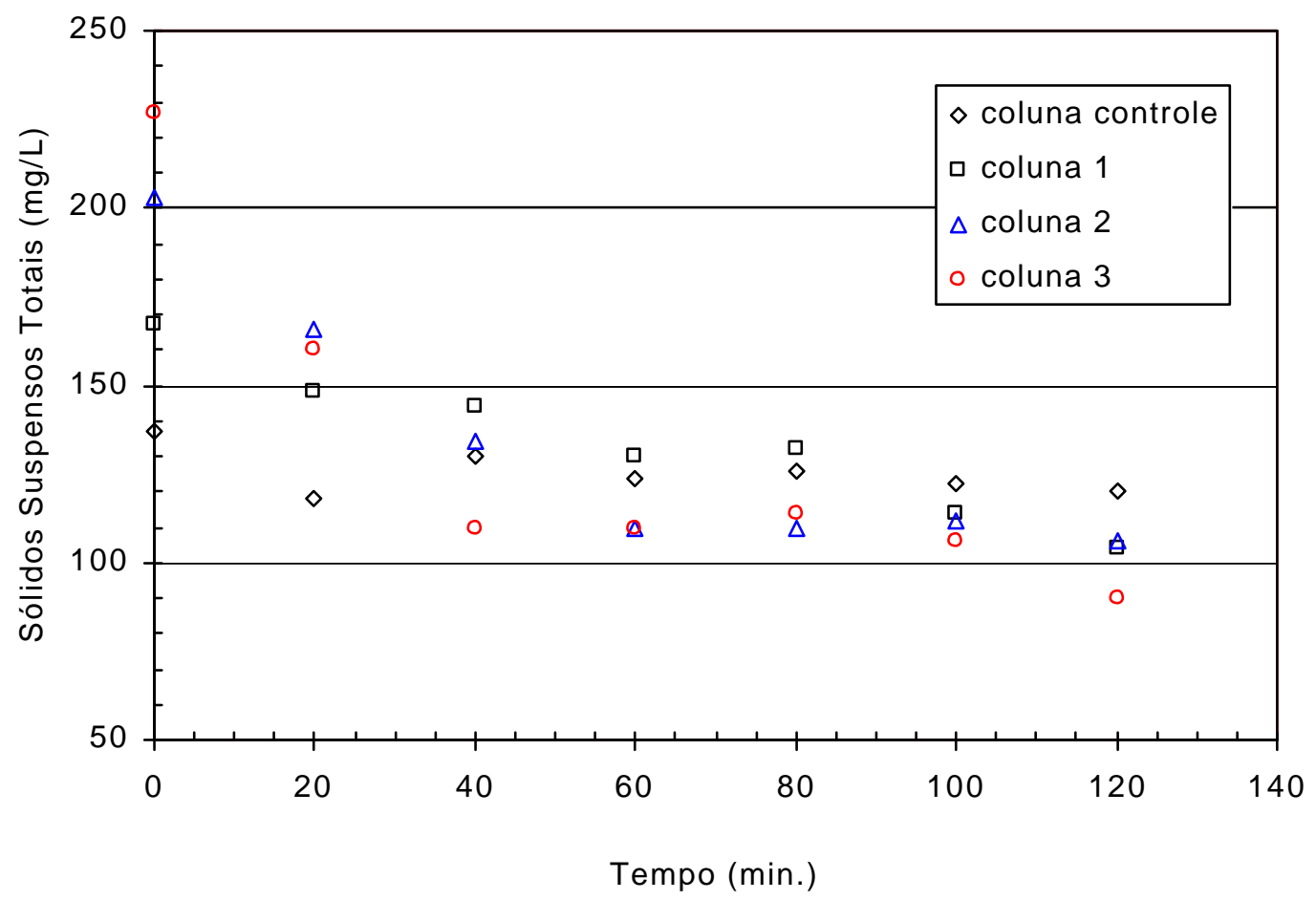

Figura 5.4 - Concentração de SST medidos nas amostras obtidas, em intervalos de 20 minutos, no ponto de coleta 3 de todas colunas da bateria. 


\subsubsection{Caracterização dos Sobrenadantes}

Os sobrenadantes caracterizados foram coletados após 0, 60 e 120 minutos de sedimentação, sendo que cada amostra foi obtida através da mistura de iguais volumes de alíquotas retiradas dos três pontos de coletas, obtendo uma amostra representativa ao longo da coluna de sedimentação, e os resultados encontram-se na tabela 5.6.

\subsubsection{Caracterização dos Sedimentos}

Os sedimentos caracterizados foram obtidos após 120 minutos de ensaio de sedimentação, sendo que cada amostra foi caracterizada, e os resultados encontram-se na tabela 5.7. Os sedimentos foram obtidos abrindo-se um registro localizado na base das colunas.

Tabela 5.6 - Caracterização dos sobrenadantes coletados nas colunas de sedimentação durante o ensaio de sedimentação, simulando um decantador primário de ETE, nos tempos 0, 60 e 120 minutos.

\begin{tabular}{|c|c|c|c|c|c|c|c|c|c|c|c|c|}
\hline \multirow{3}{*}{ PARÂMETROS } & \multicolumn{4}{|c|}{ TEMPO = 0 min. } & \multicolumn{4}{|c|}{ TEMPO = $60 \mathrm{~min}}$. & \multicolumn{4}{|c|}{ TEMPO = 120 min. } \\
\hline & \multicolumn{4}{|c|}{ COLUNAS } & \multicolumn{4}{|c|}{ COLUNAS } & \multicolumn{4}{|c|}{ COLUNAS } \\
\hline & Controle & 1 & 2 & 3 & C & 1 & 2 & 3 & C & 1 & 2 & 3 \\
\hline $\mathrm{pH}$ & 6,9 & 7,0 & 7,0 & 7,1 & 6,9 & 7,0 & 7,1 & 7,1 & 6,9 & 7,0 & 7,1 & 7,2 \\
\hline Cor (uC) & 1535 & 1675 & 2005 & 2050 & 1620 & 1604 & 1460 & 1290 & 1419 & 1275 & 1236 & 1024 \\
\hline Turbidez (UT) & 78,0 & 79,4 & 92,8 & 96,4 & 79,9 & 70,3 & 69,5 & 66,3 & 79,1 & 65,6 & 64,6 & 63,2 \\
\hline SST (mg/L) & 137 & 167 & 203 & 227 & 114 & 120 & 114 & 110 & 112 & 106 & 98 & 94 \\
\hline SSF (mg/L) & 20 & 43 & 60 & 80 & 16 & 14 & 26 & 26 & 16 & 18 & 20 & 18 \\
\hline SSV (mg/L) & 117 & 124 & 143 & 147 & 98 & 106 & 88 & 84 & 96 & 88 & 78 & 76 \\
\hline $\mathrm{DQO}(\mathrm{mg} / \mathrm{L})$ & 381 & 365 & 342 & 367 & 382 & 332 & 308 & 330 & 357 & 313 & 301 & 292 \\
\hline $\begin{array}{l}\text { Coliformes } \\
\text { Totais } \\
(\mathrm{NMP} / 100 \mathrm{~mL}) \times 10^{5}\end{array}$ & NR & NR & NR & NR & NR & NR & NR & NR & 2,76 & 2,76 & 2,55 & 2,31 \\
\hline $\begin{array}{l}\text { Escherichia coli } \\
(\mathrm{NMP} / 100 \mathrm{~mL}) \times 10^{5}\end{array}$ & NR & NR & NR & NR & NR & NR & NR & NR & 1,19 & 1,05 & 0,73 & 0,62 \\
\hline $\begin{array}{c}\text { Ancylostomidae } \\
\text { (Ovos / L) }\end{array}$ & 167 & NR & NR & NR & NR & NR & NR & NR & 6 & 3 & ND & ND \\
\hline $\begin{array}{r}\text { Strongyloides } \\
\text { (Larvas / L) }\end{array}$ & 83 & NR & NR & NR & NR & NR & NR & NR & 2 & ND & ND & ND \\
\hline
\end{tabular}


Tabela 5.7 - Caracterização do sedimento obtido no ensaio de sedimentação.

\begin{tabular}{lcccc}
\hline & \multicolumn{4}{c}{ TEMPO = 120 min. } \\
\cline { 2 - 5 } \multicolumn{1}{c}{ PARÂMETROS } & \multicolumn{4}{c}{ COLUNAS } \\
\cline { 2 - 5 } & $\mathrm{C}$ & 1 & 2 & 3 \\
\hline PH & 7,0 & 7,2 & 7,1 & 7,2 \\
ST $(\mathrm{g} / \mathrm{L})$ & 14,425 & 17,425 & 23,275 & 25,225 \\
ST Fixos $(\mathrm{g} / \mathrm{L})$ & 3,225 & 7,225 & 11,425 & 13,625 \\
ST Voláteis $(\mathrm{g} / \mathrm{L})$ & 11,220 & 10,200 & 11,850 & 11,400 \\
Resistência Específica $\left(\times 10^{3} \mathrm{~m} / \mathrm{kg}\right)$ & 8,47 & Sem material & 2,13 & 2,11 \\
\hline
\end{tabular}

\subsubsection{Ensaios de toxicidade anaeróbia - Teste da atividade metanogênica}

O inóculo utilizado no ensaio de toxicidade anaeróbia foi submetido a caracterização onde foram medidos o teor sólidos totais, fixos e voláteis, e os resultados encontram-se na tabela 5.8.

Tabela 5.8 - Concentração de Sólidos presente no inóculo anaeróbio utilizados nos ensaios de toxicidade anaeróbia.

\begin{tabular}{cc}
\hline PARÂMETROS & INÓCULO ANAERÓBIO \\
\hline ST $(\mathrm{g} / \mathrm{L})$ & 87,73 \\
ST Fixos $(\mathrm{g} / \mathrm{L})$ & 40,50 \\
ST Voláteis $(\mathrm{g} / \mathrm{L})$ & 47,23 \\
\hline
\end{tabular}

Através do teste de atividade metanogênica do lodo obtido no decantador primário verificou-se a toxicidade em condições anaeróbias. Os lodos do decantador primário foram obtidos em ensaios de sedimentação utilizando amostras compostas por resíduo da limpeza de decantador, água de lavagem de filtro e esgoto sanitário. Cada frasco-reator foi preparado para manter as condições estabelecidas na metodologia, sua composição encontra-se na tabela 5.9. 
Tabela 5.9 - Composição dos frascos-reator.

\begin{tabular}{|c|c|c|c|c|c|c|c|c|c|}
\hline \multirow{3}{*}{ Frasco-reator } & \multicolumn{9}{|c|}{ COMPOSIÇÃO } \\
\hline & \multicolumn{4}{|c|}{ Lodo de decantador primário } & \multicolumn{4}{|c|}{ Inóculo de reator anaeróbio } & \multirow{2}{*}{$\begin{array}{c}\begin{array}{c}\text { Água } \\
\text { destilada }\end{array} \\
\begin{array}{c}\text { Vol. } \\
(\mathrm{mL})\end{array}\end{array}$} \\
\hline & $\begin{array}{l}\text { Vol. } \\
(\mathrm{mL})\end{array}$ & $\begin{array}{l}\text { SST } \\
(\mathrm{g} / \mathrm{L})\end{array}$ & $\begin{array}{l}\text { SSF } \\
(\mathrm{g} / \mathrm{L})\end{array}$ & $\begin{array}{l}\text { SSV } \\
\text { (g/L) }\end{array}$ & $\begin{array}{l}\text { Vol. } \\
(\mathrm{mL})\end{array}$ & $\begin{array}{l}\text { SST } \\
(\mathrm{g} / \mathrm{L})\end{array}$ & $\begin{array}{l}\text { SSF } \\
(\mathrm{g} / \mathrm{L})\end{array}$ & $\begin{array}{l}\text { SSV } \\
(g / L)\end{array}$ & \\
\hline Frasco controle & 120,5 & 14,425 & 3,225 & 11,200 & 57,2 & 87,73 & 40,50 & 47,23 & 122,30 \\
\hline Frasco 1 & 132,4 & 17,425 & 7,225 & 10,200 & 57,2 & 87,73 & 40,50 & 47,23 & 110,40 \\
\hline Frasco 2 & 113,9 & 23,275 & 11,425 & 11,850 & 57,2 & 87,73 & 40,50 & 47,23 & 128,90 \\
\hline Frasco 3 & 118,4 & 25,225 & 13,625 & 11,400 & 57,2 & 87,73 & 40,50 & 47,23 & 124,40 \\
\hline
\end{tabular}

Os resultados dos testes de atividade metanogênica encontram-se no gráfico da figura 5.5 , onde foram plotados os valores de concentração real do metano produzido em cada frasco-reator em função do tempo. Nota-se, que a maior quantidade de metano foi produzida no frasco-reator controle, o qual não recebeu resíduo da ETA-SC. Os demais frascos-reator tiveram uma decrescente produção de metano a medida que se aumentou a quantidade de resíduo, evidenciando uma interferência negativa.

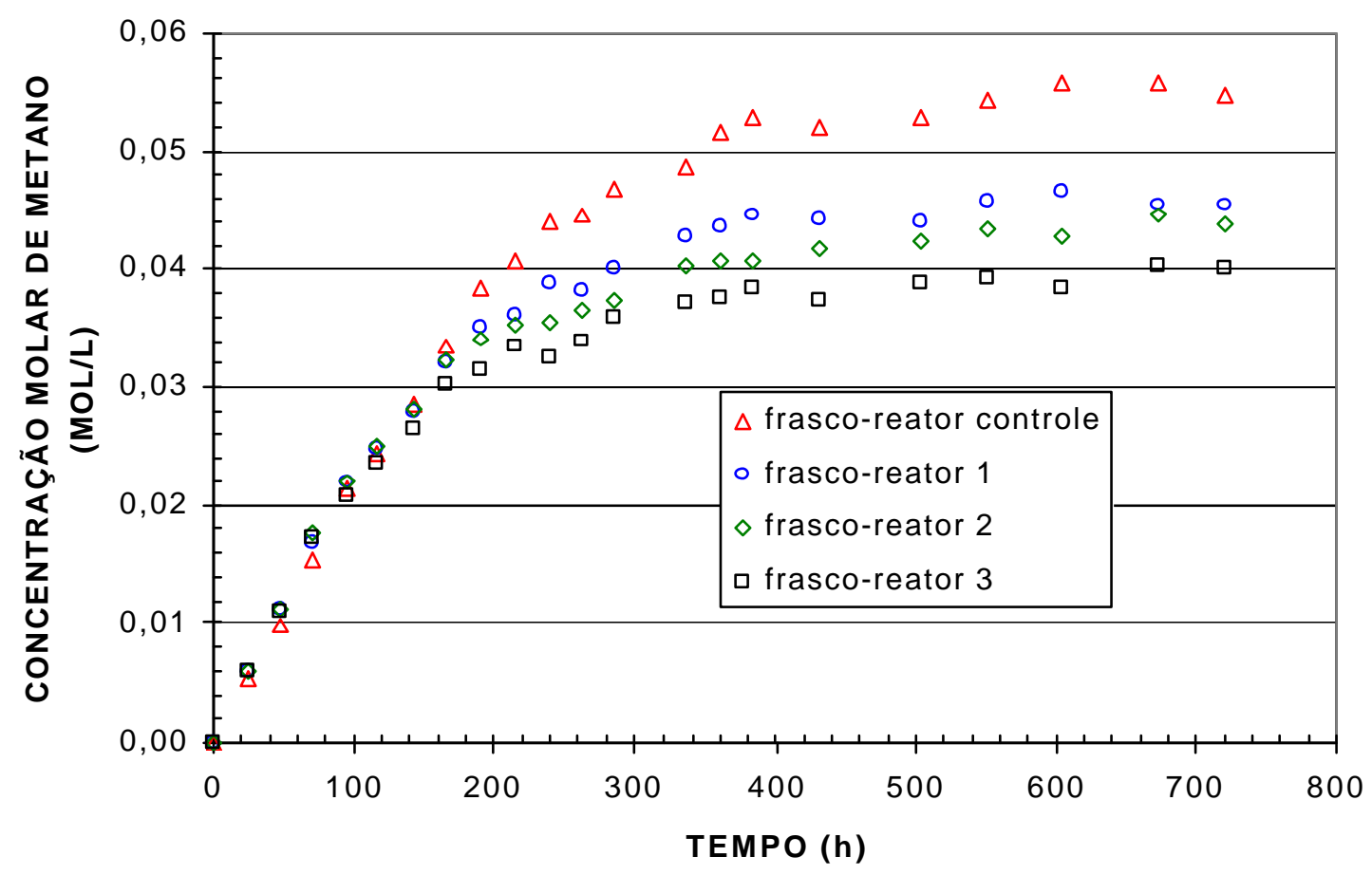

Figura 5.5 - Concentração de metano obtida nos frascos-reator durante o teste de atividade metanogênica. 


\subsection{Análise microscópica}

Foram realizadas duas séries de análises microscópicas no licor misto dos frascos-reator, sendo uma após 8 dias e outra após 16 dias de incubação .

Após 8 dias de incubação foi encontrado no frasco-reator controle predominância de bactérias metanogênicas em forma de bastonetes, que apresentam fluorescência e produzem metano pela via hidrogenotrófica. As bactérias do gênero Methanothrix sp apresentaram-se em quantidade inferior em relação às bactérias em forma de bastonetes. Foram encontradas em pequena quantidade bactérias metanogênicas do gênero Methanosarcina $s p$, metanococos, que apresentam fluorescência, e bactérias em forma de bacilos curvos semelhantes às redutoras de sulfato.

Nos frascos-reator 1, 2 e 3, comparados ao frasco-reator controle, foi observado que as bactérias do gênero Methanothrix $s p$ diminuíram e as bactérias em forma de bastonetes tiveram um ligeiro aumento, sendo progressivo no sentido do menos concentrado, frasco-reator 1 , para o mais concentrado, frasco-reator 3. Nestes três frascos-reator foram encontradas, em pequena quantidade, bactérias metanogênicas em forma de cocos e Methanosarcina sp. No frasco-reator 3, ao contrário do 1 e 2 , não foram encontrados bacilos curvos, semelhantes às redutoras de sulfato.

Após 16 dias de incubação no frasco-reator controle existiu a predominância de bacilos metanogênicos fluorescentes e bacilos não metanogênicos, poucas bactérias Methanothrix spe não foram encontrados metanococos e Methanosarcina sp.

Nos frascos 1, 2 e 3, comparados ao frasco controle, foi observado que existiu um maior número de bacilos fluorescentes e, já em estado de deterioração, poucas Methanothrix sp. O aumento dos bacilos fluorescentes foi progressivo no sentido do menos concentrado, frasco-reator 1 , para o mais concentrado, frascoreator 3. Nos três frascos foram encontrados bactérias em forma de bacilos curvos semelhantes às redutora de sulfato, além de hifas de fungos e poucos bacilos não fluorescentes.

As fotografias das figuras 5.6 a 5.8 ilustram os organismos encontrados nos licor mistos dos frascos-reator. 


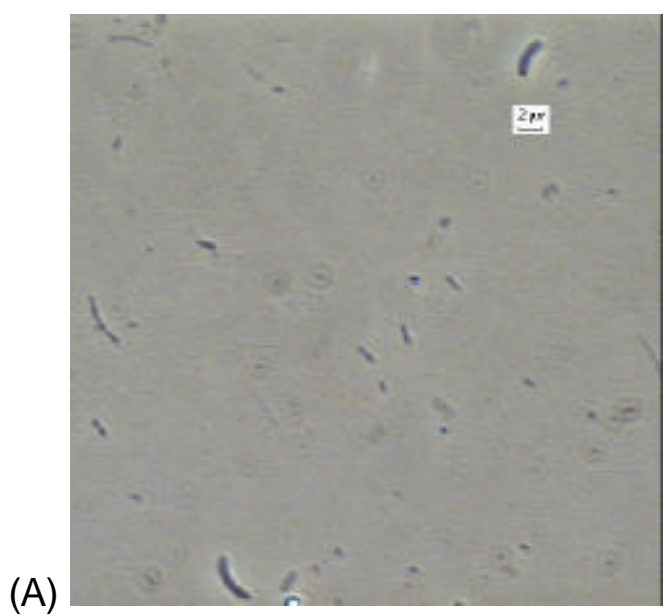

(B)

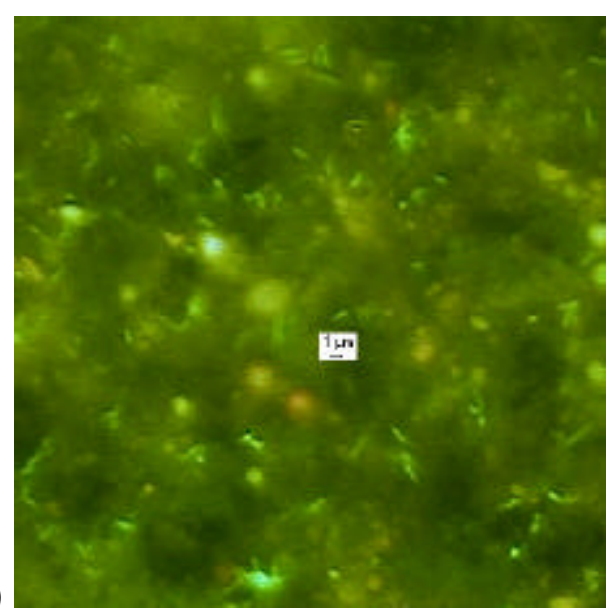

Figura 5.6 - (A) Presença de bactérias em forma de bacilos curvos semelhantes às redutoras de sulfato no Frasco-reator controle. (B) Presença de bactérias fluorescentes em forma de bastonetes no Frasco-reator controle.

(A)

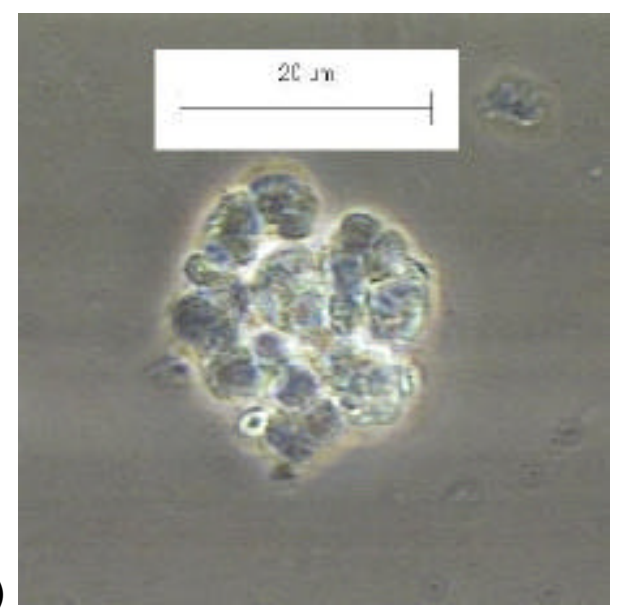

(B)

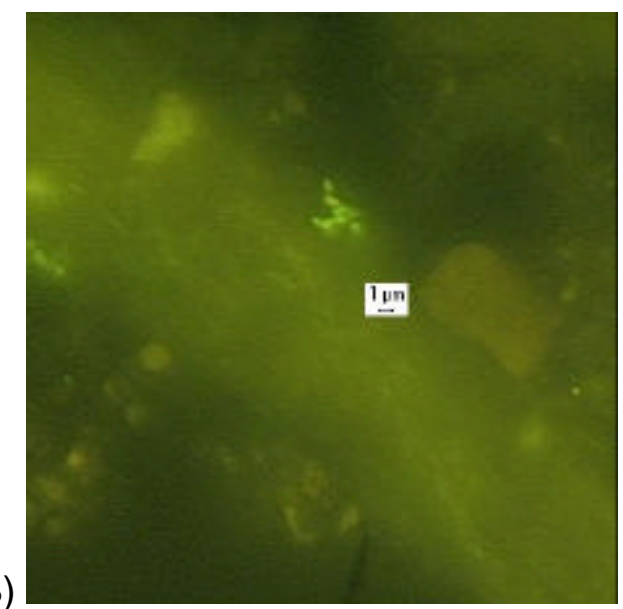

Figura 5.7 - (A) Methanosarcina sp presente no Frasco-reator 1. (B) Pouca quantidade de metanococos fluorescentes presentes no Frasco-reator 1.

(A)

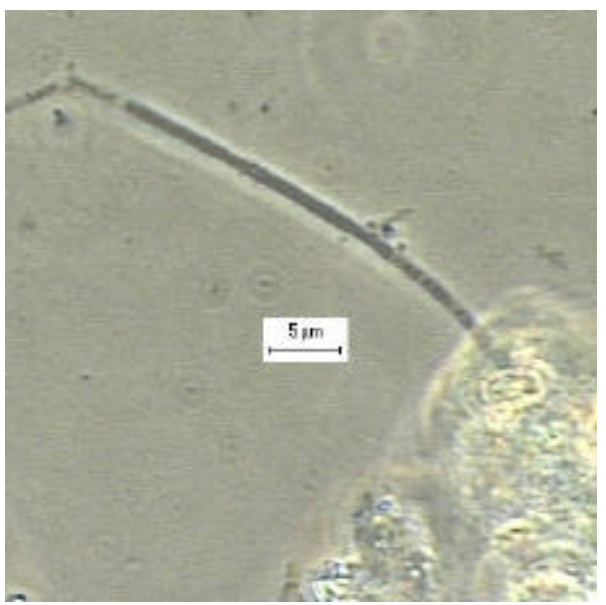

(B)

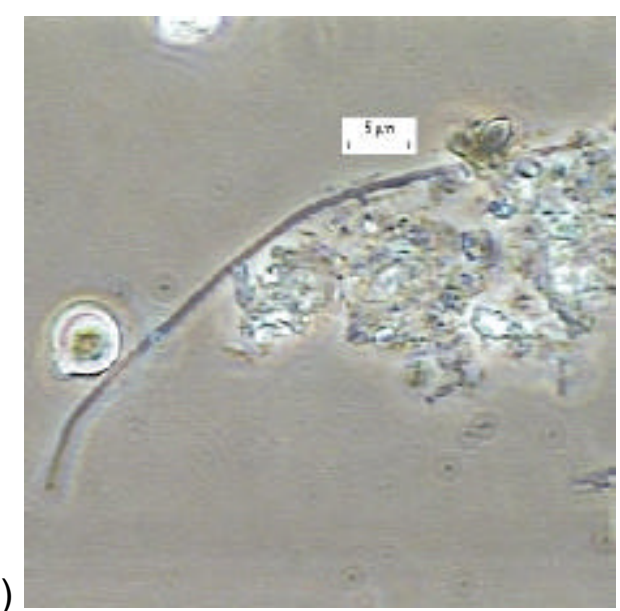

Figura 5.8 - (A) Methanothrix sp presentes no frasco-reator 2. (B) Methanothrix sp 


\subsection{SEGUNDA FASE}

Na segunda fase, foram estudadas as possíveis interferências que poderão advir na unidade de escala piloto simulando a ETE-Araraquara, após receber resíduo da ETA-Fonte, que utiliza cloreto férrico como coagulante primário, verificando o desempenho das lagoas de aeração e de sedimentação, além do processo de desidratação do lodo obtido na lagoa de sedimentação, complementando com ensaios de lixiviação e solubilização.

Este estudo poderá ser decisivo na opção pelo lançamento do resíduo, produzido na ETA-Fonte, na ETE-Araraquara, gerando uma substancial economia, não sendo necessário a implantação de um sistema exclusivo para o tratamento do resíduo gerado na ETA-Fonte. 


\subsubsection{Caracterização do Resíduo da Descarga do Decantador}

Após coleta do resíduo da descarga do decantador, de forma composta, foi realizado análise em laboratório caracterizando a amostra, e o resultado encontrase na tabela 5.10 .

Tabela 5.10 - Caracterização da amostra composta do resíduo da descarga do decantador, coletada dia 24 de janeiro de 2003.

\begin{tabular}{lc}
\hline PARÂMETROS & RESULTADOS \\
\hline DQO (mg O $/ \mathrm{L})$ & 150 \\
Turbidez (UT) & 1584 \\
pH & 8,4 \\
Sólidos Sedimentáveis em Cone Imhoff(mL/L) & 210 \\
Sólidos Totais (mg/L) & 1855 \\
Sólidos Fixos (mg/L) & 1420 \\
Sólidos Voláteis (mg/L) & 435 \\
Sólidos Suspensos Totais (mg/L) & 1606 \\
Sólidos Suspensos Fixos (mg/L) & 1312 \\
Sólidos Suspensos Voláteis (mg/L) & 294 \\
Sólidos Dissolvidos Totais (mg/L) & 249 \\
Sólidos Dissolvidos Fixos (mg/L) & 108 \\
Sólidos Dissolvidos Voláteis (mg/L) & 141 \\
Nitrato (mgN/L) & 0,52 \\
Nitrito (mg N/L) & 0,18 \\
Nitrogênio amoniacal (mg N/L) & 0,81 \\
Nitrogênio Total Kjeldahl (mg N/L) & 7,56 \\
Fosfato Total (mg P/L) & 0,05 \\
Cloreto (mg Cl/L) & 18 \\
Ferro (mg Fe/L) & 341 \\
Manganês (mg Mg/L) & 3,490 \\
Cobre (mg Cu/L) & 0,100 \\
Zinco (mg Zn/L & 0,099 \\
Chumbo (mg Pb/L) & 0,226 \\
Cádmio (mg Cd/L) & 0,001 \\
Níquel (mg Ni/L) & 0,052 \\
Cromo (mg Cr/L) & 0,179 \\
Cobalto (mg Co/L) & 0,138 \\
\hline & \\
&
\end{tabular}




\subsubsection{Caracterização do Resíduo da Lavagem dos Filtros}

Após coleta do resíduo da lavagem dos filtros, de forma composta, foi realizada análise em laboratório caracterizando a amostra. O resultado da caracterização encontra-se na tabela 5.11.

Tabela 5.11 - Caracterização da amostra composta do resíduo da lavagem do filtro, coletada dia 24 de janeiro de 2003.

\begin{tabular}{lc}
\hline PARÂMETROS & RESULTADOS \\
\hline DQO (mg $\left.\mathrm{O}_{2} / \mathrm{L}\right)$ & 37 \\
Turbidez (UT) & 239 \\
pH & 8,61 \\
Sólidos Sedimentáveis em Cone Imhoff(mL/L) & 30 \\
Sólidos Totais (mg/L) & 329 \\
Sólidos Fixos (mg/L) & 233 \\
Sólidos Voláteis (mg/L) & 96 \\
Sólidos Suspensos Totais (mg/L) & 298 \\
Sólidos Suspensos Fixos (mg/L) & 226 \\
Sólidos Suspensos Voláteis (mg/L) & 72 \\
Sólidos Dissolvidos Totais (mg/L) & 40 \\
Sólidos Dissolvidos Fixos (mg/L) & 16 \\
Sólidos Dissolvidos Voláteis (mg/L) & 24 \\
Nitrato (mgN/L) & 0,100 \\
Nitrito (mg N/L) & 0,045 \\
Nitrogênio amoniacal (mg N/L) & 0,102 \\
Nitrogênio Total Kjeldahl (mg N/L) & 4,20 \\
Fosfato Total (mg P/L) & 0,65 \\
Cloreto (mg Cl/L) & 12 \\
Ferro (mg Fe/L) & 40 \\
Manganês (mg Mg/L) & 0,440 \\
Cobre (mg Cu/L) & 0,009 \\
Zinco (mg Zn/L & 0,015 \\
Chumbo (mg Pb/L) & 0,036 \\
Cádmio (mg Cd/L) & 0,001 \\
Níquel (mg Ni/L) & 0,010 \\
Cromo (mg Cr/L) & 0,030 \\
Cobalto (mg Co/L) & 0,025 \\
Temperatura $/ \mathrm{C})$ & 27,0 \\
\hline & \\
&
\end{tabular}




\subsubsection{Ensaio em Escala Piloto}

A operação das ETEs-piloto teve início no dia 06/01/2003. Neste dia as lagoas, em escala piloto, foram preenchidas com o licor da lagoa de aeração da ETE-Araraquara. A operação das ETEs-piloto foram divididas em duas fases descritas as seguir.

\subsubsection{Fase Inicial}

$\mathrm{Na}$ fase inicial as ETEs-piloto foram alimentadas durante um período de 30 dias apenas com esgoto sanitário na vazão de $6,94 \mathrm{~mL} / \mathrm{min}$, correspondendo a 10L/d, mantendo um tempo de detenção de 3 dias nas lagoas de aeração e de 1,5 dias nas lagoas de sedimentação.

Durante a operação das ETEs-piloto foram realizadas caracterizações do esgoto afluente ao sistema e do efluente final das lagoas de sedimentação, além do ensaio para determinação da taxa de consumo de oxigênio e exame microscópico.

\subsection{Caracterização do Afluente e Efluente}

A eficiência do sistema e a qualidade do efluente das lagoas de sedimentação foram avaliadas através de caracterizações do afluente e efluente no decorrer da operação das ETEs-pilotos.

Nas tabelas 5.12 a 5.14 estão os resultados das caracterizações realizadas durante a fase inicial de operação das ETEs-piloto, onde ficou constatado que os efluentes apresentaram características parecidas, indicando que as ETEs-piloto operavam em condições semelhantes. 
Tabela 5.12 - Caracterização das amostras do afluente e efluente da ETE-Piloto, coletadas no dia 15/01/2003.

\begin{tabular}{|c|c|c|c|}
\hline \multirow[b]{2}{*}{ Parâmetros } & \multicolumn{3}{|c|}{ Coleta 15/01/2003 } \\
\hline & Afluente & $\begin{array}{c}\text { Efluente } \\
\text { LS-1 }\end{array}$ & $\begin{array}{c}\text { Efluente } \\
\text { LS-2 }\end{array}$ \\
\hline $\mathrm{DQO}(\mathrm{mg} / \mathrm{L})$ & 797 & 137 & 105 \\
\hline $\mathrm{DBO}(\mathrm{mg} / \mathrm{L})$ & 314 & 74 & 80 \\
\hline Remoção de DQO (\%) & NR & 92,8 & 86,8 \\
\hline Remoção de DBO (\%) & NR & 76,4 & 74,5 \\
\hline $\mathrm{PH}$ & 6,8 & 7,1 & 7,0 \\
\hline Condutividade elétrica ( $\mu \mathrm{s} / \mathrm{cm})$ & 592 & 493 & 498 \\
\hline Sólidos Totais (mg/L) & 629 & 303 & 311 \\
\hline Sólidos Fixos (mg/L) & 275 & 242 & 279 \\
\hline Sólidos Voláteis (mg/L) & 354 & 61 & 32 \\
\hline Sólidos Suspensos Totais (mg/L) & 254 & 19 & 15 \\
\hline Sólidos Suspensos Fixos (mg/L) & 84 & 5 & 3 \\
\hline Sólidos Suspensos Voláteis (mg/L) & 170 & 14 & 12 \\
\hline Sólidos Dissolvidos Totais (mg/L) & 375 & 284 & 296 \\
\hline Sólidos Dissolvidos Fixos (mg/L) & 191 & 237 & 276 \\
\hline Sólidos Dissolvidos Voláteis (mg/L) & 184 & 47 & 20 \\
\hline Sol. Sedimentáveis Cone Imhoff $(\mathrm{mL} / \mathrm{L})$ - 1 hora & 1,5 & 0,0 & 0,0 \\
\hline Turbidez (UT) & NR & 27,0 & 28,0 \\
\hline Cor (UC) & NR & 46,0 & 46,0 \\
\hline Cloreto (mg Cl`L) & 34,3 & 38,1 & 32,5 \\
\hline Nitrogênio amoniacal (mg N/L) & 5,05 & 8,40 & 5,04 \\
\hline Nitrato (mg N/L) & 0,30 & 4,67 & 5,68 \\
\hline Nitrito (mg N/L) & 0,12 & 0,46 & 0,49 \\
\hline Nitrogênio Total Kjeldahl (mg N/L) & 26,88 & 14,36 & 10,6 \\
\hline Fosfato Total (mg P/L) & 8,56 & 5,25 & 4,97 \\
\hline
\end{tabular}

NR - Não realizado. 
Tabela 5.13 - Caracterização das amostras do afluente e efluente da ETE-Piloto, coletadas no dia 24/01/2003.

\begin{tabular}{|c|c|c|c|}
\hline \multirow[b]{2}{*}{ Parâmetros } & \multicolumn{3}{|c|}{ Coleta 24/01/2003 } \\
\hline & Afluente & $\begin{array}{c}\text { Efluente } \\
\text { LS-1 }\end{array}$ & $\begin{array}{c}\text { Efluente } \\
\text { LS-2 }\end{array}$ \\
\hline $\mathrm{DQO}(\mathrm{mg} / \mathrm{L})$ & 745 & 130,0 & 112,0 \\
\hline $\mathrm{DBO}(\mathrm{mg} / \mathrm{L})$ & 318 & 68,0 & 70,0 \\
\hline Remoção de DQO (\%) & NR & 82,6 & 85,0 \\
\hline Remoção de DBO (\%) & NR & 78,6 & 78,0 \\
\hline $\mathrm{pH}$ & 6,7 & 7,2 & 7,3 \\
\hline Condutividade elétrica ( $\mu \mathrm{s} / \mathrm{cm})$ & 533 & 500 & 510 \\
\hline Sólidos Totais (mg/L) & 598 & 325 & 299 \\
\hline Sólidos Fixos (mg/L) & 254 & 269 & 234 \\
\hline Sólidos Voláteis (mg/L) & 344 & 56 & 65 \\
\hline Sólidos Suspensos Totais (mg/L) & 240 & 12 & 9 \\
\hline Sólidos Suspensos Fixos (mg/L) & 28 & 1 & 0 \\
\hline Sólidos Suspensos Voláteis (mg/L) & 212 & 11 & 9 \\
\hline Sólidos Dissolvidos Totais (mg/L) & 358 & 313 & 290 \\
\hline Sólidos Dissolvidos Fixos (mg/L) & 226 & 268 & 234 \\
\hline Sólidos Dissolvidos Voláteis (mg/L) & 132 & 45 & 56 \\
\hline Sol. Sedimentáveis Cone Imhoff (mL/L) - 1 hora & 1,0 & 0,0 & 0,0 \\
\hline Turbidez (UT) & NR & 71,0 & 111,0 \\
\hline Cor (UC) & NR & 84,0 & 91,0 \\
\hline Cloreto (mg Cl/L) & 35,3 & 36,2 & 29,7 \\
\hline Nitrogênio amoniacal (mg N/L) & 19,32 & 5,88 & 9,24 \\
\hline Nitrato (mg N/L) & 0,26 & 1,96 & 3,89 \\
\hline Nitrito (mg N/L) & 0,16 & 0,44 & 0,40 \\
\hline Nitrogênio Total Kjeldahl (mg N/L) & 49,85 & 12,38 & 14,44 \\
\hline Fosfato Total (mg P/L) & 6,32 & 4,96 & 4,61 \\
\hline
\end{tabular}

NR - Não realizado. 
Tabela 5.14 - Caracterização das amostras do afluente e efluente da ETE-Piloto, coletadas no dia 07/02/2003.

\begin{tabular}{|c|c|c|c|}
\hline \multirow[b]{2}{*}{ Parâmetros } & \multicolumn{3}{|c|}{ Coleta $07 / 02 / 2003$} \\
\hline & Afluente & $\begin{array}{c}\text { Efluente } \\
\text { LS-1 }\end{array}$ & $\begin{array}{c}\text { Efluente } \\
\text { LS-2 }\end{array}$ \\
\hline $\mathrm{DQO}(\mathrm{mg} / \mathrm{L})$ & 228 & 78 & 80 \\
\hline $\mathrm{DBO}(\mathrm{mg} / \mathrm{L})$ & 63 & 56 & 61 \\
\hline Remoção de DQO (\%) & NR & 89,3 & 89,0 \\
\hline Remoção de DBO (\%) & NR & 84,6 & 83,2 \\
\hline $\mathrm{pH}$ & 6,9 & 7,1 & 7,1 \\
\hline Condutividade elétrica ( $\mu \mathrm{s} / \mathrm{cm})$ & 448 & 490 & 495 \\
\hline Sólidos Totais (mg/L) & 520 & 290 & 299 \\
\hline Sólidos Fixos (mg/L) & 68 & 240 & 244 \\
\hline Sólidos Voláteis (mg/L) & 452 & 50 & 55 \\
\hline Sólidos Suspensos Totais (mg/L) & 78 & 10 & 9 \\
\hline Sólidos Suspensos Fixos (mg/L) & 6 & 1 & 1 \\
\hline Sólidos Suspensos Voláteis (mg/L) & 72 & 9 & 8 \\
\hline Sólidos Dissolvidos Totais (mg/L) & 442 & 280 & 290 \\
\hline Sólidos Dissolvidos Fixos (mg/L) & 62 & 239 & 243 \\
\hline Sólidos Dissolvidos Voláteis (mg/L) & 380 & 41 & 47 \\
\hline Sol. Sedimentáveis Cone Imhoff $(\mathrm{mL} / \mathrm{L})$ - 1 hora & 1,0 & 0,0 & 0,0 \\
\hline Turbidez (UT) & NR & 26,0 & 28,0 \\
\hline Cor (UC) & NR & 50,0 & 52,0 \\
\hline Cloreto (mg Cl/L) & 22,3 & 24,0 & 26,0 \\
\hline Nitrogênio amoniacal (mg N/L) & 25,2 & 2,41 & 2,64 \\
\hline Nitrato $(\mathrm{mg} \mathrm{N} / \mathrm{L})$ & 0,10 & 1,80 & 2,05 \\
\hline Nitrito (mg N/L) & 0,08 & 0,70 & 0,74 \\
\hline Nitrogênio Total Kjeldahl (mg N/L) & 26,44 & 6,01 & 5,90 \\
\hline Fosfato Total (mg P/L) & 4,23 & 4,80 & 4,90 \\
\hline
\end{tabular}

NR - Não realizado. 


\subsection{Exame Microscópico}

O exame microscópico foi realizado com o objetivo de comparar as características microscópicas das duas ETEs-piloto antes de iniciar o lançamento do resíduo da ETA-Fonte em um dos sistemas.

Após 30 dias de operação foi realizado exame microscópico no licor misto das lagoas de aeração. O material coletado foi examinado evidenciando a presença de uma grande variedade de microrganismos com a presença de rotíferos, anelídeos e nematóides indicando boas condições de depuração das duas ETEs piloto.

A eficiência de depuração do sistema e o licor com boas características podem ser avaliados através da presença de microrganismos tais como Ciliados livre-natantes, Nematóides e ciliados pedunculados.

Alguns microrganismos, tais como o Rizopode semelhante a Amoeba (Figura 5.11-A), é indicativo de lodo jovem caracterizando início de operação.

A presença do ciliado livre Aspidisca sp (ver figura 5.13-B) pode ser indicativo de que está ocorrendo nitrificação.

Microrganismos como Anelídeos do gênero Aelosoma (ver figura 5.12-A) em grande quantidade pode ser indicativo de excesso de oxigênio dissolvido. Tal microorganismo foi encontrado em condições normais não caracterizando excesso de oxigênio dissolvido.

O exame microscópico indicou que ambos os sistemas apresentavam características de lodo jovem, em início de operação e, em condições semelhantes apresentando microrganismos alguns dos quais estão ilustrados nas fotografias das figuras 5.9 a 5.14 . 

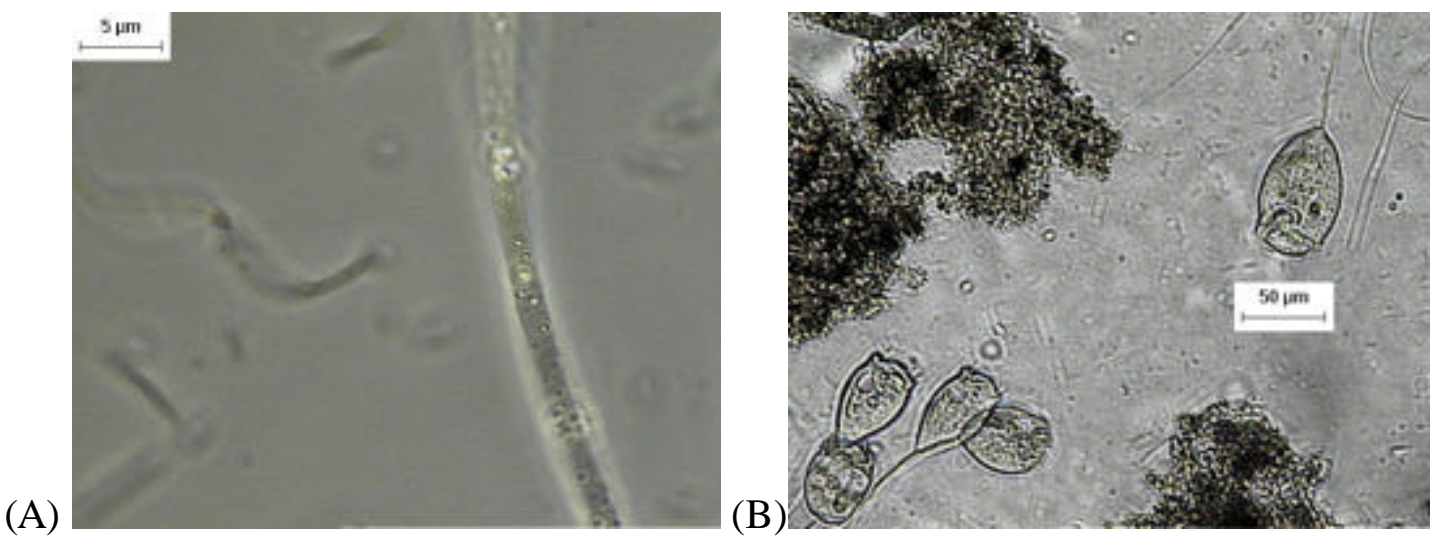

Figura 5.9 - (A) Bactéria filamentosa Beggiatoa spp. Observe a presença de grânulos de enxofre. (B) Presença deVorticella spp, pertencente a Classe Ciliata, sendo um ciliado pedunculado.

(A)

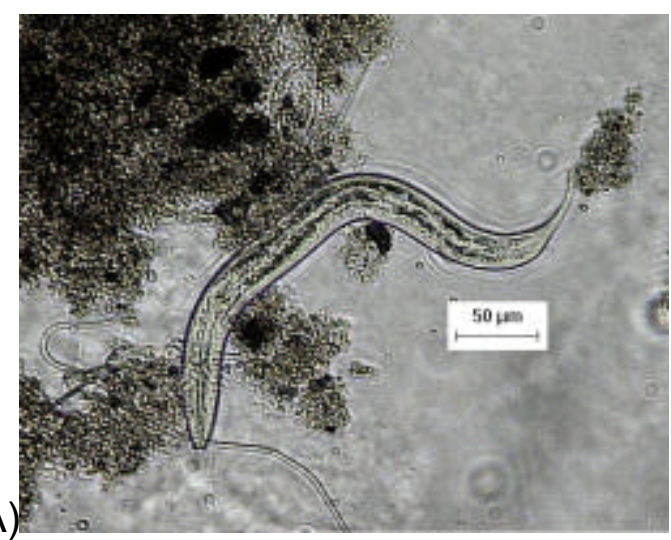

(B)

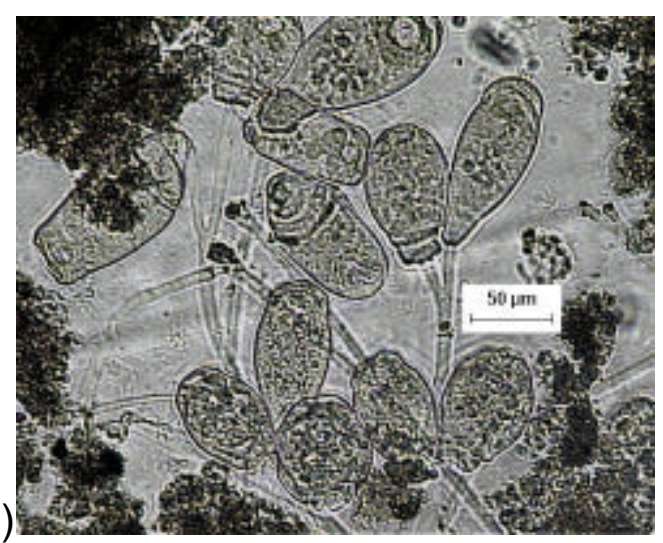

Figura 5.10 - (A) Nematóide, indicativo de boas condições de depuração. (B) Lodo com boas características, onde se observa Colônia de Epistylis spp pertencente ao grupodos ciliados pedunculados.

(A)

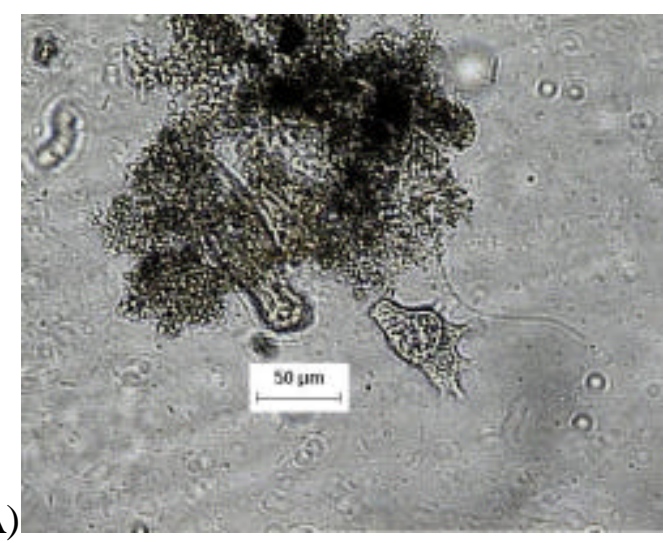

(B)

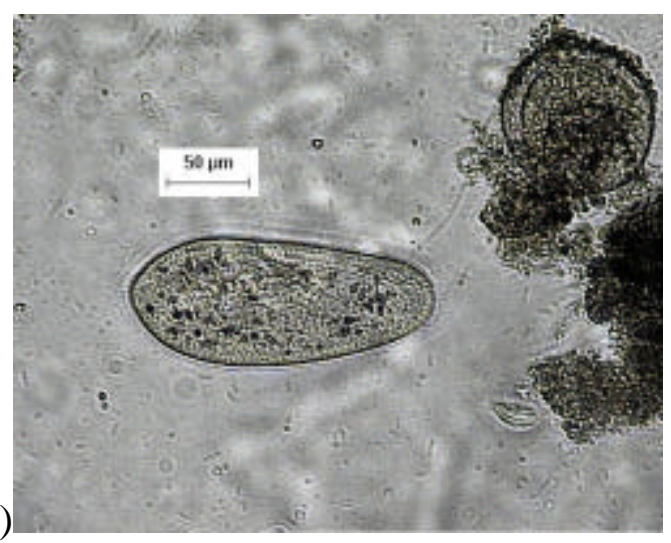

Figura 5.11 - (A) Rizopode semelhante a Amoeba pertencente à classe Sarcodina. Indica lodo jovem, característica de início de operação. (B) Ciliado livre-natante do gênero Paramecium spp. Indicativo de boa depuração. 

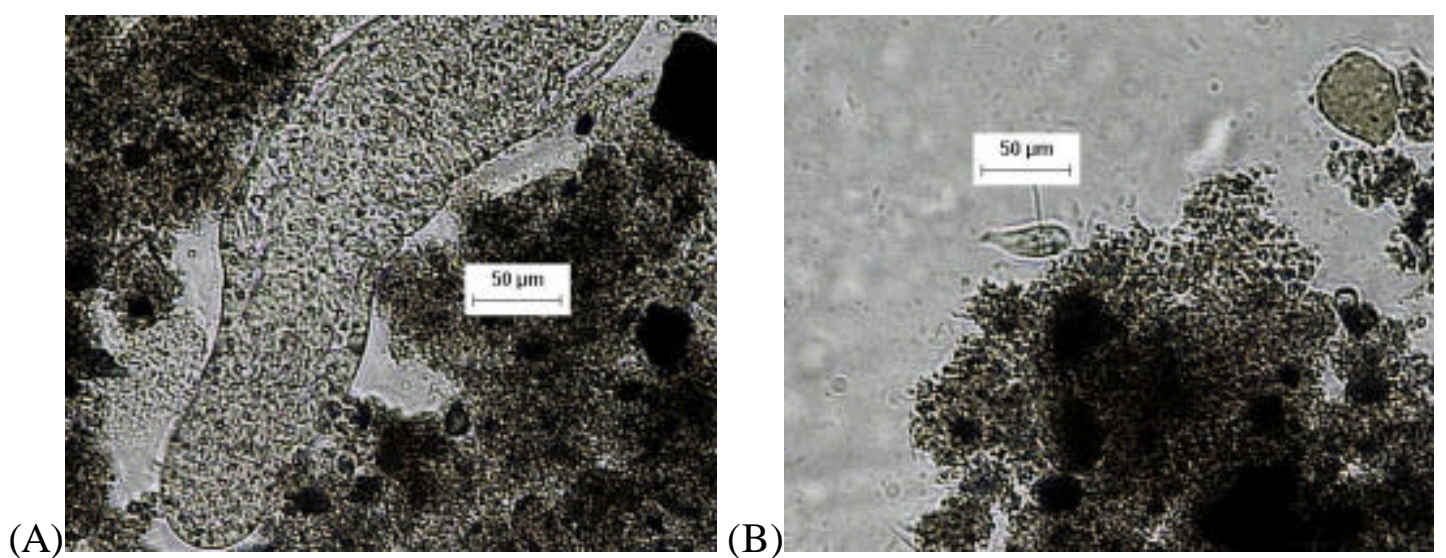

Figura 5.12 - (A) Anelídeos do gênero Aelosoma. Em grande quantidade indica excesso de OD. (B) Ciliado livre natante semelhante a Trachelophyllum spp, pertencente a Classe Ciliata. Indicativo de boas condições de depuração.
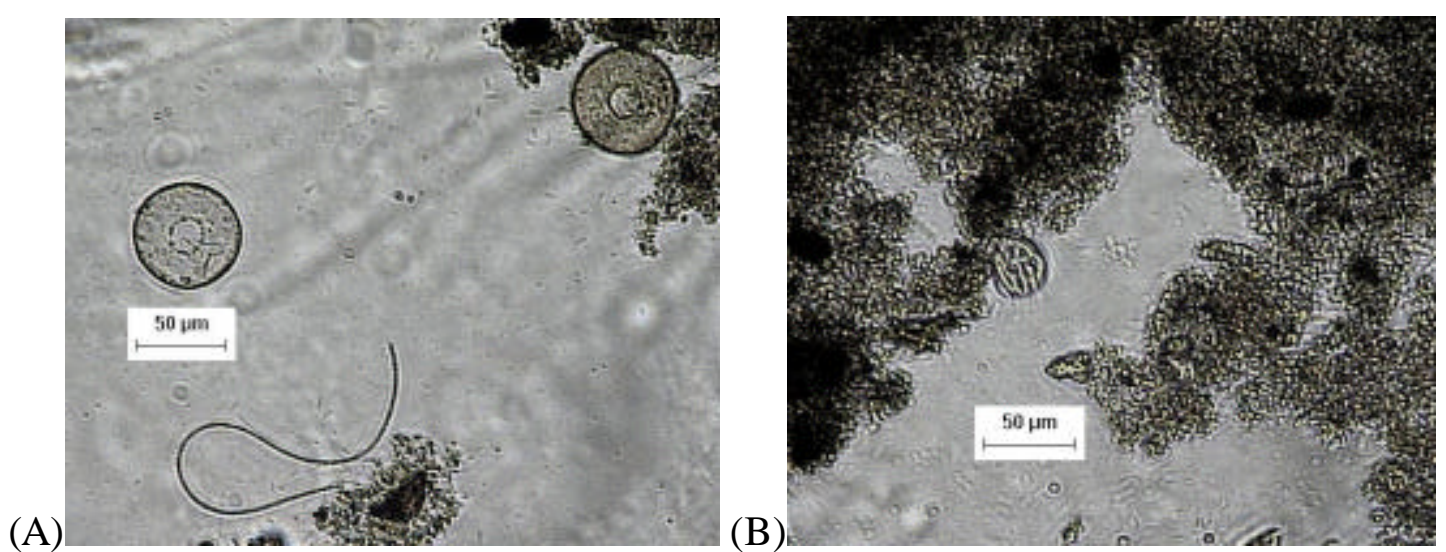

Figura 5.13 - (A) Rizópode com teca semelhante à Arcella, pertencente a Classe Sarcodina (amebas) e Bactéria filamentosa Beggiatoa spp. (B) Presença de Aspidisca sp, sendo um ciliado livre, predador de flocos. Indicativo de Nitrificação.

(A)
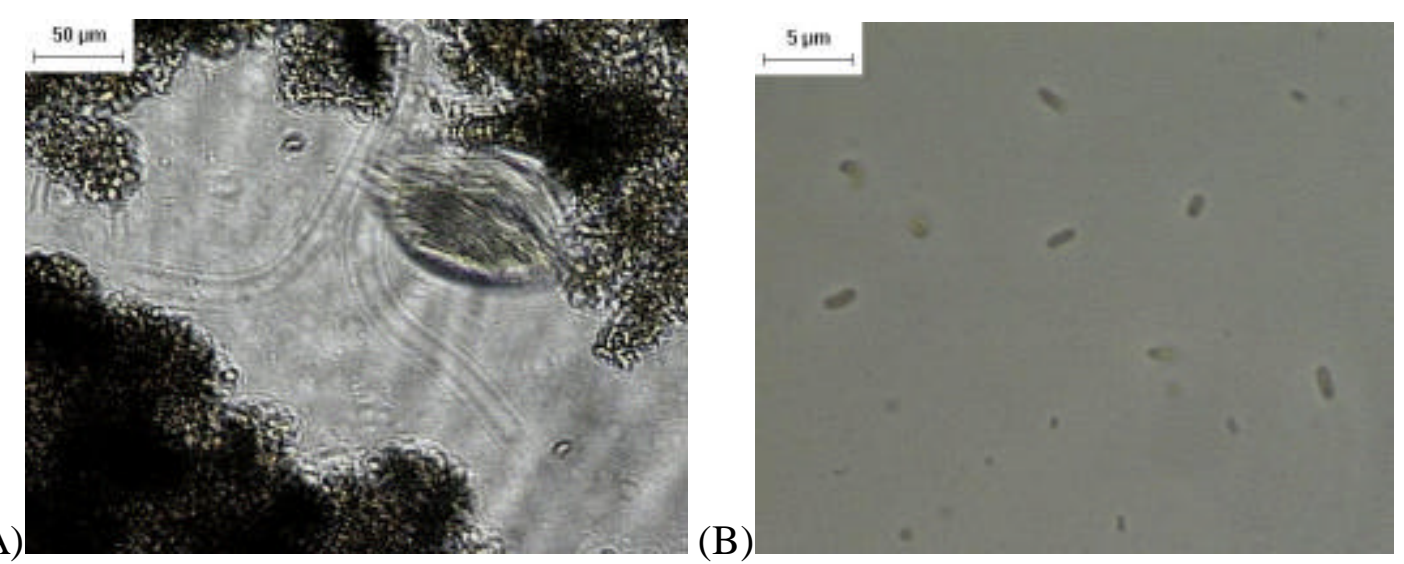

Figura 5.14 - (A) Espécie semelhante ao gênero Euplotes spp, sendo um ciliado livre, predador de flocos. (B) Bactérias em forma de bacilos. Pode ser indicativo de início de operação. 


\subsubsection{Fase Final}

Nesta fase a lagoa de aeração 2, considerada como branco, recebeu apenas esgoto sanitário, enquanto que a lagoa de aeração 1 , considerada como teste, recebeu, além de esgoto sanitário, resíduo da ETA-Fonte. O volume de resíduo adicionado à ETE-piloto, seguiu a mesma proporção caso fosse lançado em escala real, ou seja, 2,69\% do resíduo da descarga de decantador e 2,26\% de resíduo da lavagem dos filtros, sendo $269 \mathrm{~mL}$ e $226 \mathrm{~mL}$, respectivamente. Este quantidade de resíduo representa um total de 57,33 $\mathrm{mg}$ ST / L de esgoto sanitário e 49,92 g SST / L de esgoto sanitário. O total de resíduo disposto na ETE-piloto, em função dos 90 dias de operação, foi de $44,55 \mathrm{~L}$, gerando uma quantidade de sólidos totais de $51,60 \mathrm{~g}$ e SST de $44,94 \mathrm{~g}$. A forma de dispor este resíduo foi manual e diariamente em intervalos de 2 horas, divididas em 6 alíquotas de $82,5 \mathrm{~mL}$.

\subsection{Caracterização do Afluente e Efluente}

Visando avaliar as interferências ou vantagens que poderia advir com o lançamento do resíduo da ETA-Fonte foram realizadas caracterizações do efluente final das lagoas de sedimentação durante os 90 dias de operação das ETEs-piloto.

Para avaliar a eficiência do tratamento foram realizadas, simultaneamente à caracterização do efluente, caracterizações do afluente às ETEs-piloto. Os resultados estão contidos nas tabelas 5.15 a 5.27. Para melhor interpretação, os resultados foram plotados nos gráficos das figuras 5.15 a 5.23 .

Observa-se, na figura 22 e 23, que os metais Fe e Mn se apresentaram em maior concentração no efluente final da ETE-Piloto 1, que recebeu resíduo da ETAFonte, em relação a ETE-piloto 2. Os demais metais pesquisados não apresentaram muitas diferenças.

As amostras dos sobrenadantes coletadas no dia 14/05 foram submetidas a análise bacteriológica e os resultados encontram-se na tabela 5.27.

Nota-se, na tabela 5.27, na caracterização realizada do afluente, que dentre os metais pesquisados o Fe foi o que apresentou maior concentração.

Os resultados obtidos deixam claro que os parâmetros pesquisados no efluente da lagoa de sedimentação 1, proveniente da ETE-piloto que recebeu resíduo da ETA-Fonte, não sofreram interferências negativas, gerando um efluente de melhor qualidade. 
Tabela 5.15 - Caracterização das amostras do afluente e efluente da ETE-Piloto, coletadas no dia 12/02/2003.

\begin{tabular}{|c|c|c|c|}
\hline \multirow[b]{2}{*}{ Parâmetros } & \multicolumn{3}{|c|}{ Coleta $12 / 02 / 2003$} \\
\hline & Afluente & $\begin{array}{c}\text { Efluente } \\
\text { LS-1 }\end{array}$ & $\begin{array}{c}\text { Efluente } \\
\text { LS-2 }\end{array}$ \\
\hline $\mathrm{DQO}(\mathrm{mg} / \mathrm{L})$ & 757 & 36 & 39 \\
\hline $\mathrm{DBO}(\mathrm{mg} / \mathrm{L})$ & 446 & 12 & 16 \\
\hline Remoção de DQO (\%) & NR & 95,2 & 94,8 \\
\hline Remoção de DBO (\%) & NR & 97,3 & 96,4 \\
\hline $\mathrm{pH}$ & 6,6 & 6,60 & 7,0 \\
\hline Condutividade elétrica $(\mu \mathrm{s} / \mathrm{cm})$ & 590 & 482 & 480 \\
\hline Sólidos Totais (mg/L) & 581 & 517 & 573 \\
\hline Sólidos Fixos (mg/L) & 120 & 209 & 295 \\
\hline Sólidos Voláteis (mg/L) & 461 & 308 & 278 \\
\hline Sólidos Suspensos Totais (mg/L) & 121 & 8 & 10 \\
\hline Sólidos Suspensos Fixos (mg/L) & 18 & 2 & 1 \\
\hline Sólidos Suspensos Voláteis (mg/L) & 103 & 6 & 9 \\
\hline Sólidos Dissolvidos Totais (mg/L) & 460 & 509 & 563 \\
\hline Sólidos Dissolvidos Fixos (mg/L) & 102 & 207 & 294 \\
\hline Sólidos Dissolvidos Voláteis (mg/L) & 358 & 302 & 230 \\
\hline Sol. Sedimentáveis Cone Imhoff $(\mathrm{mL} / \mathrm{L})-1$ hora & 6,0 & 0,0 & 0,0 \\
\hline Turbidez (UT) & NR & 15,0 & 15,0 \\
\hline Cor (UC) & NR & 33,0 & 32,0 \\
\hline Cloreto (mg Cl$\left.{ }^{-} / \mathrm{L}\right)$ & 53,6 & 39,20 & 41,20 \\
\hline Nitrogênio amoniacal (mg N/L) & 0,59 & 0,37 & 0,15 \\
\hline Nitrato (mg N/L) & 0,25 & 7,73 & 8,85 \\
\hline Nitrito (mg N/L) & 0,09 & 0,45 & 0,26 \\
\hline Nitrogênio Total Kjeldahl (mg N/L) & 6,73 & NR & NR \\
\hline Manganês (mg/L) & NR & 0,074 & 0,090 \\
\hline Ferro (mg/L) & NR & 3,326 & 4,219 \\
\hline Níquel (mg/L) & NR & $<0,001$ & 0,085 \\
\hline Zinco (mg/L) & NR & 0,225 & 0,506 \\
\hline Chumbo (mg/L) & NR & 0,440 & 0,445 \\
\hline Cádmio (mg/L) & NR & $<0,001$ & $<0,001$ \\
\hline Cobre (Mg/L) & NR & 0,030 & 0,169 \\
\hline Cromo (mg/L) & NR & 0,265 & 0,228 \\
\hline Cobalto (mg/L) & NR & $<0,001$ & 0,016 \\
\hline
\end{tabular}

NR - Não realizado. 
Tabela 5.16 - Caracterização das amostras do afluente e efluente da ETE-Piloto, coletadas no dia 19/02/2003.

\begin{tabular}{|c|c|c|c|}
\hline \multirow[b]{2}{*}{ Parâmetros } & \multicolumn{3}{|c|}{ Coleta 19/02/2003 } \\
\hline & Afluente & $\begin{array}{c}\text { Efluente } \\
\text { LS-1 }\end{array}$ & $\begin{array}{c}\text { Efluente } \\
\text { LS-2 }\end{array}$ \\
\hline $\mathrm{DQO}(\mathrm{mg} / \mathrm{L})$ & 710 & 46 & 50 \\
\hline $\mathrm{DBO}(\mathrm{mg} / \mathrm{L})$ & 439 & 14 & 20 \\
\hline Remoção de DQO (\%) & NR & 93,5 & 92,9 \\
\hline Remoção de DBO (\%) & NR & 96,8 & 95,4 \\
\hline $\mathrm{pH}$ & 6,6 & 6,8 & 6,9 \\
\hline Condutividade elétrica ( $\mu \mathrm{s} / \mathrm{cm})$ & 484 & 527 & 560 \\
\hline Sólidos Totais (mg/L) & 590 & 560 & 655 \\
\hline Sólidos Fixos (mg/L) & 309 & 325 & 283 \\
\hline Sólidos Voláteis (mg/L) & 281 & 235 & 372 \\
\hline Sólidos Suspensos Totais (mg/L) & 76 & 6 & 10 \\
\hline Sólidos Suspensos Fixos (mg/L) & 22 & 1 & 1 \\
\hline Sólidos Suspensos Voláteis (mg/L) & 54 & 5 & 9 \\
\hline Sólidos Dissolvidos Totais (mg/L) & 514 & 554 & 645 \\
\hline Sólidos Dissolvidos Fixos (mg/L) & 287 & 324 & 282 \\
\hline Sólidos Dissolvidos Voláteis (mg/L) & 227 & 230 & 363 \\
\hline Sol. Sedimentáveis Cone Imhoff (mL/L) - 1 hora & 3,0 & 0,0 & 0,0 \\
\hline Turbidez (UT) & NR & 16,0 & 27,0 \\
\hline Cor (UC) & NR & 42,0 & 55,0 \\
\hline Cloreto (mg Cl/L) & 44,0 & 41,2 & 42,1 \\
\hline Nitrogênio amoniacal (mg N/L) & 0,48 & 0,15 & 0,26 \\
\hline Nitrato (mg N/L) & 0,27 & 9,23 & 9,10 \\
\hline Nitrito (mg N/L) & 0,08 & 0,45 & 0,45 \\
\hline Nitrogênio Total Kjeldahl (mg N/L) & NR & NR & NR \\
\hline Fosfato Total (mg P/L) & 6,10 & 5,5 & 6,4 \\
\hline
\end{tabular}

NR - Não realizado 
Tabela 5.17 - Caracterização das amostras do afluente e efluente da ETE-Piloto, coletadas no dia 26/02/2003.

\begin{tabular}{|c|c|c|c|}
\hline \multirow[b]{2}{*}{ Parâmetros } & \multicolumn{3}{|c|}{ Coleta $26 / 02 / 2003$} \\
\hline & Afluente & $\begin{array}{c}\text { Efluente } \\
\text { LS-1 }\end{array}$ & $\begin{array}{c}\text { Efluente } \\
\text { LS-2 }\end{array}$ \\
\hline $\mathrm{DQO}(\mathrm{mg} / \mathrm{L})$ & 687 & 41 & 58 \\
\hline $\mathrm{DBO}(\mathrm{mg} / \mathrm{L})$ & 252 & 33 & 31 \\
\hline Remoção de DQO (\%) & NR & 94,0 & 91,5 \\
\hline Remoção de DBO (\%) & NR & 86,9 & 87,7 \\
\hline $\mathrm{pH}$ & 6,4 & 6,6 & 6,4 \\
\hline Condutividade elétrica $(\mu \mathrm{s} / \mathrm{cm})$ & 463 & 367 & 389 \\
\hline Sólidos Totais (mg/L) & 655 & 591 & 388 \\
\hline Sólidos Fixos (mg/L) & 263 & 282 & 313 \\
\hline Sólidos Voláteis (mg/L) & 392 & 309 & 75 \\
\hline Sólidos Suspensos Totais (mg/L) & 187 & 17 & 14 \\
\hline Sólidos Suspensos Fixos (mg/L) & 27 & 2 & 4 \\
\hline Sólidos Suspensos Voláteis (mg/L) & 160 & 15 & 10 \\
\hline Sólidos Dissolvidos Totais (mg/L) & 467 & 574 & 374 \\
\hline Sólidos Dissolvidos Fixos (mg/L) & 235 & 280 & 309 \\
\hline Sólidos Dissolvidos Voláteis (mg/L) & 232 & 294 & 65,0 \\
\hline Sol. Sedimentáveis Cone Imhoff (mL/L) - 1 hora & 4,0 & 0,0 & 0,0 \\
\hline Turbidez (UT) & NR & 57,0 & 52,0 \\
\hline Cor (UC) & NR & 61,0 & 77,0 \\
\hline Cloreto (mg Cl`/L) & 38,3 & 40,2 & 44,0 \\
\hline Nitrogênio amoniacal (mg N/L) & 23,52 & 0,41 & 0,49 \\
\hline Nitrato (mg N/L) & 0,16 & 16,04 & 20,38 \\
\hline Nitrito (mg N/L) & 0,11 & 0,47 & 0,37 \\
\hline Nitrogênio Total Kjeldahl (mg N/L) & 32,4 & 5,88 & 5,04 \\
\hline Fosfato Total (mg P/L) & 7,23 & 4,68 & 6,29 \\
\hline Manganês (mg/L) & NR & 0,075 & 0,069 \\
\hline Ferro (mg/L) & NR & 3,304 & 2,308 \\
\hline Níquel (mg/L) & NR & 0,054 & 0,105 \\
\hline Zinco (mg/L) & NR & 0,199 & 0,224 \\
\hline Chumbo (mg/L) & NR & 0,255 & 0,233 \\
\hline Cádmio (mg/L) & NR & 0,009 & 0,004 \\
\hline Cobre (Mg/L) & NR & 0,033 & 0,024 \\
\hline Cromo (mg/L) & NR & 0,214 & 0,215 \\
\hline Cobalto (mg/L) & NR & 0,017 & 0,051 \\
\hline
\end{tabular}

NR - Não realizado. 
Tabela 5.18 - Caracterização das amostras do afluente e efluente da ETE-Piloto, coletadas no dia 08/03/2003.

\begin{tabular}{|c|c|c|c|}
\hline \multirow[b]{2}{*}{ Parâmetros } & \multicolumn{3}{|c|}{ Coleta $08 / 03 / 2003$} \\
\hline & Afluente & $\begin{array}{c}\text { Efluente } \\
\text { LS-1 }\end{array}$ & $\begin{array}{c}\text { Efluente } \\
\text { LS-2 }\end{array}$ \\
\hline $\mathrm{DQO}(\mathrm{mg} / \mathrm{L})$ & 615 & 62 & 84 \\
\hline $\mathrm{DBO}(\mathrm{mg} / \mathrm{L})$ & 264 & 17 & 21 \\
\hline Remoção de DQO (\%) & NR & 89,9 & 86,3 \\
\hline Remoção de DBO (\%) & NR & 93,5 & 92,2 \\
\hline $\mathrm{pH}$ & 6,5 & 6,89 & 6,64 \\
\hline Condutividade elétrica $(\mu \mathrm{s} / \mathrm{cm})$ & 915 & 418 & 412 \\
\hline Sólidos Totais (mg/L) & 810 & 410 & 434 \\
\hline Sólidos Fixos (mg/L) & 263 & 142 & 330 \\
\hline Sólidos Voláteis (mg/L) & 547 & 268 & 104 \\
\hline Sólidos Suspensos Totais (mg/L) & 282 & 7 & 9 \\
\hline Sólidos Suspensos Fixos (mg/L) & 22 & 1 & 2 \\
\hline Sólidos Suspensos Voláteis (mg/L) & 260 & 6 & 7 \\
\hline Sólidos Dissolvidos Totais (mg/L) & 528 & 403 & 425 \\
\hline Sólidos Dissolvidos Fixos (mg/L) & 241 & 141 & 328 \\
\hline Sólidos Dissolvidos Voláteis (mg/L) & 287 & 262 & 97 \\
\hline Sol. Sedimentáveis Cone Imhoff $(\mathrm{mL} / \mathrm{L})$ - 1 hora & 4,0 & 0,0 & 0,0 \\
\hline Turbidez (UT) & NR & 23,0 & 33,0 \\
\hline Cor (UC) & NR & 36,0 & 57,0 \\
\hline Cloreto (mg Cl$/ 2 / L)$ & 57,4 & 39,2 & 40,2 \\
\hline Nitrogênio amoniacal (mg N/L) & 18,55 & 0,12 & 0,25 \\
\hline Nitrato (mg N/L) & 0,70 & 14,3 & 17,68 \\
\hline Nitrito (mg N/L) & 0,06 & 0,44 & 0,29 \\
\hline Nitrogênio Total Kjeldahl (mg N/L) & 22,68 & NR & NR \\
\hline Fosfato Total (mg P/L) & 6,58 & 3,81 & 4,60 \\
\hline Manganês (mg/L) & NR & 0,087 & 0,055 \\
\hline Ferro (mg/L) & NR & 3,512 & 2,481 \\
\hline Níquel (mg/L) & NR & 0,010 & 0,036 \\
\hline Zinco (mg/L) & NR & 0,365 & 0,298 \\
\hline Chumbo (mg/L) & NR & 1,021 & 0,311 \\
\hline Cádmio (mg/L) & NR & 0,013 & 0,011 \\
\hline Cobre $(\mathrm{Mg} / \mathrm{L})$ & NR & 0,030 & 0,029 \\
\hline Cromo (mg/L) & NR & 0,282 & 0,233 \\
\hline Cobalto (mg/L) & NR & 0,022 & 0,021 \\
\hline
\end{tabular}

NR - Não realizado. 
Tabela 5.19 - Caracterização das amostras do afluente e efluente da ETE-Piloto, coletadas no dia 19/03/2003.

\begin{tabular}{|c|c|c|c|}
\hline \multirow[b]{2}{*}{ Parâmetros } & \multicolumn{3}{|c|}{ Coleta 19/03/2003 } \\
\hline & Afluente & $\begin{array}{c}\text { Efluente } \\
\text { LS-1 }\end{array}$ & $\begin{array}{c}\text { Efluente } \\
\text { LS-2 }\end{array}$ \\
\hline $\mathrm{DQO}(\mathrm{mg} / \mathrm{L})$ & 704 & 86 & 123 \\
\hline $\mathrm{DBO}(\mathrm{mg} / \mathrm{L})$ & 241 & 26 & 32 \\
\hline Remoção de DQO (\%) & NR & 87,8 & 82,5 \\
\hline Remoção de DBO (\%) & NR & 89,2 & 86,6 \\
\hline $\mathrm{PH}$ & 6,7 & 7,2 & 7,3 \\
\hline Condutividade elétrica ( $\mu \mathrm{s} / \mathrm{cm})$ & 549 & 490 & 481 \\
\hline Sólidos Totais (mg/L) & 707 & 716 & 479 \\
\hline Sólidos Fixos (mg/L) & 290 & 313 & 277 \\
\hline Sólidos Voláteis (mg/L) & 417 & 403 & 202 \\
\hline Sólidos Suspensos Totais (mg/L) & 166 & 18 & 31 \\
\hline Sólidos Suspensos Fixos (mg/L) & 23 & 5 & 5 \\
\hline Sólidos Suspensos Voláteis (mg/L) & 143 & 13 & 26 \\
\hline Sólidos Dissolvidos Totais (mg/L) & 541 & 698 & 448 \\
\hline Sólidos Dissolvidos Fixos (mg/L) & 267 & 308 & 272 \\
\hline Sólidos Dissolvidos Voláteis (mg/L) & 274 & 390 & 176 \\
\hline Sol. Sedimentáveis Cone Imhoff (mL/L) - 1 hora & 5,0 & 0,0 & 0,0 \\
\hline Turbidez (UT) & NR & 33,0 & 39,0 \\
\hline Cor (UC) & NR & 43,0 & 63,0 \\
\hline Cloreto (mg Cl`/L) & 61,3 & 41,2 & 41,2 \\
\hline Nitrogênio amoniacal (mg N/L) & 9,15 & 0,02 & 0,40 \\
\hline Nitrato (mg N/L) & 0,50 & 14,10 & 8,08 \\
\hline Nitrito (mg N/L) & 0,15 & 0,18 & 0,48 \\
\hline Nitrogênio Total Kjeldahl (mg N/L) & NR & NR & NR \\
\hline Fosfato Total (mg P/L) & 7,59 & 4,50 & 5,88 \\
\hline Manganês (mg/L) & NR & 0,061 & 0,051 \\
\hline Ferro (mg/L) & NR & 2,579 & 2,394 \\
\hline Níquel (mg/L) & NR & 0,015 & 0,043 \\
\hline Zinco (mg/L) & NR & 0,183 & 0,186 \\
\hline Chumbo (mg/L) & NR & 0,317 & 0,675 \\
\hline Cádmio (mg/L) & NR & 0,019 & 0,009 \\
\hline Cobre (Mg/L) & NR & 0,029 & 0,047 \\
\hline Cromo (mg/L) & NR & 0,233 & 0,243 \\
\hline Cobalto (mg/L) & NR & 0,021 & 0,014 \\
\hline
\end{tabular}

NR - Não realizado. 
Tabela 5.20 - Caracterização das amostras do afluente e efluente da ETE-Piloto, coletadas no dia 26/03/2003.

\begin{tabular}{|c|c|c|c|}
\hline \multirow[b]{2}{*}{ Parâmetros } & \multicolumn{3}{|c|}{ Coleta $26 / 03 / 2003$} \\
\hline & Afluente & $\begin{array}{c}\text { Efluente } \\
\text { LS-1 }\end{array}$ & $\begin{array}{c}\text { Efluente } \\
\text { LS-2 }\end{array}$ \\
\hline $\mathrm{DQO}(\mathrm{mg} / \mathrm{L})$ & 707 & 66 & 78 \\
\hline $\mathrm{DBO}(\mathrm{mg} / \mathrm{L})$ & 296 & 12 & 29 \\
\hline Remoção de DQO (\%) & NR & 90,7 & 89,0 \\
\hline Remoção de DBO (\%) & NR & 96,0 & 90,2 \\
\hline $\mathrm{pH}$ & 6,6 & 7,20 & 7,0 \\
\hline Condutividade elétrica ( $\mu \mathrm{s} / \mathrm{cm})$ & 453 & 422 & 418 \\
\hline Sólidos Totais (mg/L) & 616 & 928 & 457 \\
\hline Sólidos Fixos (mg/L) & 238 & 325 & 292 \\
\hline Sólidos Voláteis (mg/L) & 378 & 603 & 165 \\
\hline Sólidos Suspensos Totais (mg/L) & 226 & 6 & 16 \\
\hline Sólidos Suspensos Fixos (mg/L) & 10 & 1 & 1 \\
\hline Sólidos Suspensos Voláteis (mg/L) & 216 & 5 & 15 \\
\hline Sólidos Dissolvidos Totais (mg/L) & 390 & 922 & 441 \\
\hline Sólidos Dissolvidos Fixos (mg/L) & 228 & 324 & 291 \\
\hline Sólidos Dissolvidos Voláteis (mg/L) & 162 & 598 & 150 \\
\hline Sol. Sedimentáveis Cone Imhoff $(\mathrm{mL} / \mathrm{L})$ - 1 hora & 3,0 & 0,0 & 0,0 \\
\hline Turbidez (UT) & NR & 19,0 & 32,0 \\
\hline Cor (UC) & NR & 33,0 & 51,0 \\
\hline Cloreto (mg Cl`L) & 43,1 & 45,0 & 45,0 \\
\hline Nitrogênio amoniacal (mg N/L) & 23,52 & ND & ND \\
\hline Nitrato $(\mathrm{mg} \mathrm{N} / \mathrm{L})$ & 0,26 & 17,36 & 10,06 \\
\hline Nitrito (mg N/L) & 0,03 & 0,30 & 0,44 \\
\hline Nitrogênio Total Kjeldahl (mg N/L) & 29,15 & 2,52 & 4,20 \\
\hline Fosfato Total (mg P/L) & 7,72 & 4,49 & 5,78 \\
\hline
\end{tabular}

ND - Não detectado. 
Tabela 5.21 - Caracterização das amostras do afluente e efluente da ETE-Piloto, coletadas no dia 02/04/2003.

\begin{tabular}{|c|c|c|c|}
\hline \multirow[b]{2}{*}{ Parâmetros } & \multicolumn{3}{|c|}{ Coleta $02 / 04 / 2003$} \\
\hline & Afluente & $\begin{array}{c}\text { Efluente } \\
\text { LS-1 }\end{array}$ & $\begin{array}{c}\text { Efluente } \\
\text { LS-2 }\end{array}$ \\
\hline $\mathrm{DQO}(\mathrm{mg} / \mathrm{L})$ & 859 & 90 & 103 \\
\hline $\mathrm{DBO}(\mathrm{mg} / \mathrm{L})$ & 302 & 25 & 21 \\
\hline Remoção de DQO (\%) & NR & 89,5 & 88,1 \\
\hline Remoção de DBO (\%) & NR & 91,7 & 93,2 \\
\hline $\mathrm{pH}$ & 6,7 & 7,5 & 7,2 \\
\hline Condutividade elétrica $(\mu \mathrm{s} / \mathrm{cm})$ & 563 & 499 & 506 \\
\hline Sólidos Totais (mg/L) & 646 & 334 & 391 \\
\hline Sólidos Fixos (mg/L) & 258 & 264 & 254 \\
\hline Sólidos Voláteis (mg/L) & 388 & 70 & 137 \\
\hline Sólidos Suspensos Totais (mg/L) & 253 & 15 & 31 \\
\hline Sólidos Suspensos Fixos (mg/L) & 12 & 4 & 5 \\
\hline Sólidos Suspensos Voláteis (mg/L) & 241 & 11 & 26 \\
\hline Sólidos Dissolvidos Totais (mg/L) & 393 & 319 & 360 \\
\hline Sólidos Dissolvidos Fixos (mg/L) & 246 & 260 & 249 \\
\hline Sólidos Dissolvidos Voláteis (mg/L) & 147 & 59 & 111 \\
\hline Sol. Sedimentáveis Cone Imhoff (mL/L) - 1 hora & 4,0 & 0,0 & 0,0 \\
\hline Turbidez (UT) & NR & 24,0 & 34,0 \\
\hline Cor (UC) & NR & 45,0 & 49,0 \\
\hline Cloreto (mg Cl`/L) & 40,2 & 43,1 & 42,1 \\
\hline Nitrogênio amoniacal (mg N/L) & 16,60 & 0,02 & 0,16 \\
\hline Nitrato (mg N/L) & 0,17 & 12,11 & 10,18 \\
\hline Nitrito (mg N/L) & 0,05 & 0,162 & 0,467 \\
\hline Nitrogênio Total Kjeldahl (mg N/L) & 26,04 & 5,04 & 4,20 \\
\hline Fosfato Total (mg P/L) & 7,36 & 4,97 & 6,71 \\
\hline Manganês (mg/L) & NR & 0,074 & 0,049 \\
\hline Ferro (mg/L) & NR & 2,922 & 2,539 \\
\hline Níquel (mg/L) & NR & 0,022 & 0,057 \\
\hline Zinco (mg/L) & NR & 0,181 & 0,161 \\
\hline Chumbo (mg/L) & NR & 0,328 & 0,315 \\
\hline Cádmio (mg/L) & NR & 0,013 & 0,005 \\
\hline Cobre (Mg/L) & NR & 0,032 & 0,034 \\
\hline Cromo (mg/L) & NR & 0,296 & 0,272 \\
\hline Cobalto (mg/L) & NR & 0,038 & 0,037 \\
\hline
\end{tabular}

NR- Não realizado. 
Tabela 5.22 - Caracterização das amostras do afluente e efluente da ETE-Piloto, coletadas no dia 09/04/2003.

\begin{tabular}{|c|c|c|c|}
\hline \multirow[b]{2}{*}{ Parâmetros } & \multicolumn{3}{|c|}{ Coleta 09/04/2003 } \\
\hline & Afluente & $\begin{array}{c}\text { Efluente } \\
\text { LS-1 }\end{array}$ & $\begin{array}{c}\text { Efluente } \\
\text { LS-2 }\end{array}$ \\
\hline $\mathrm{DQO}(\mathrm{mg} / \mathrm{L})$ & 858 & 59 & 65 \\
\hline DBO (mg/L) & 330 & 14 & 19 \\
\hline Remoção de DQO (\%) & NR & 92,7 & 91,4 \\
\hline Remoção de DBO (\%) & NR & 93,6 & 92,4 \\
\hline $\mathrm{pH}$ & 6,8 & 7,3 & 7,2 \\
\hline Condutividade elétrica $(\mu \mathrm{s} / \mathrm{cm})$ & 562 & 500 & 491 \\
\hline Sólidos Totais (mg/L) & 569 & 450 & 365 \\
\hline Sólidos Fixos (mg/L) & 276 & 215 & 235 \\
\hline Sólidos Voláteis (mg/L) & 293 & 235 & 130 \\
\hline Sólidos Suspensos Totais (mg/L) & 194 & 8 & 18 \\
\hline Sólidos Suspensos Fixos (mg/L) & 24 & 1 & 4 \\
\hline Sólidos Suspensos Voláteis (mg/L) & 170 & 7 & 14 \\
\hline Sólidos Dissolvidos Totais (mg/L) & 375 & 442 & 347 \\
\hline Sólidos Dissolvidos Fixos (mg/L) & 252 & 214 & 231 \\
\hline Sólidos Dissolvidos Voláteis (mg/L) & 123 & 228 & 116 \\
\hline Sol. Sedimentáveis Cone Imhoff $(\mathrm{mL} / \mathrm{L})$ - 1 hora & 1,0 & 0,0 & 0,0 \\
\hline Turbidez (UT) & NR & 20,0 & 26,0 \\
\hline Cor (UC) & NR & 46,0 & 61,0 \\
\hline Cloreto (mg Cl$/ / \mathrm{L}$ ) & 54,6 & 48,2 & 47,1 \\
\hline Nitrogênio amoniacal (mg N/L) & 4,5 & 0,12 & 0,35 \\
\hline Nitrato (mg N/L) & 0,48 & 11,11 & 12,08 \\
\hline Nitrito (mg N/L) & 0,05 & 0,18 & 0,42 \\
\hline Nitrogênio Total Kjeldahl (mg N/L) & 32,7 & 5,22 & 10,21 \\
\hline Fosfato Total (mg P/L) & 7,36 & 4,51 & 6,62 \\
\hline
\end{tabular}

NR - Não realizado. 
Tabela 5.23 - Caracterização das amostras do afluente e efluente da ETE-Piloto, coletadas no dia 16/04/2003.

\begin{tabular}{|c|c|c|c|}
\hline \multirow[b]{2}{*}{ Parâmetros } & \multicolumn{3}{|c|}{ Coleta $16 / 04 / 2003$} \\
\hline & Afluente & $\begin{array}{c}\text { Efluente } \\
\text { LS-1 }\end{array}$ & $\begin{array}{c}\text { Efluente } \\
\text { LS-2 }\end{array}$ \\
\hline $\mathrm{DQO}(\mathrm{mg} / \mathrm{L})$ & 743 & 63 & 74 \\
\hline $\mathrm{DBO}(\mathrm{mg} / \mathrm{L})$ & 290 & 21 & 25 \\
\hline Remoção de DQO (\%) & NR & 92,7 & 91 \\
\hline Remoção de DBO (\%) & NR & 93,4 & 93,1 \\
\hline $\mathrm{pH}$ & 6,8 & 7,2 & 7,1 \\
\hline Condutividade elétrica ( $\mu \mathrm{s} / \mathrm{cm})$ & 555 & 529 & 544 \\
\hline Sólidos Totais (mg/L) & 871 & 311 & 346 \\
\hline Sólidos Fixos (mg/L) & 376 & 198 & 220 \\
\hline Sólidos Voláteis (mg/L) & 495 & 113 & 126 \\
\hline Sólidos Suspensos Totais (mg/L) & 306 & 6 & 16 \\
\hline Sólidos Suspensos Fixos (mg/L) & 54 & 2 & 3 \\
\hline Sólidos Suspensos Voláteis (mg/L) & 252 & 4 & 13 \\
\hline Sólidos Dissolvidos Totais (mg/L) & 565 & 305 & 330 \\
\hline Sólidos Dissolvidos Fixos (mg/L) & 322 & 196 & 217 \\
\hline Sólidos Dissolvidos Voláteis (mg/L) & 243 & 109 & 113 \\
\hline Sol. Sedimentáveis Cone Imhoff (mL/L) - 1 hora & 4,0 & 0,0 & 0,0 \\
\hline Turbidez (UT) & NR & 25,0 & 31,0 \\
\hline Cor (UC) & NR & 44,0 & 50,0 \\
\hline Cloreto (mg Cl/L) & 81,4 & 39,10 & 40,0 \\
\hline Nitrogênio amoniacal (mg N/L) & 21,6 & 0,08 & 0,08 \\
\hline Nitrato $(\mathrm{mg} \mathrm{N} / \mathrm{L})$ & 0,3 & 9,50 & 8,80 \\
\hline Nitrito (mg N/L) & 0,05 & 0,21 & 0,40 \\
\hline Nitrogênio Total Kjeldahl (mg N/L) & 23,52 & 5,18 & 9,44 \\
\hline Fosfato Total (mg P/L) & 12,64 & 4,94 & 6,24 \\
\hline
\end{tabular}

NR - Não realizado. 
Tabela 5.24 - Caracterização das amostras do afluente e efluente da ETE-Piloto, coletadas no dia 23/04/2003.

\begin{tabular}{|c|c|c|c|}
\hline \multirow[b]{2}{*}{ Parâmetros } & \multicolumn{3}{|c|}{ Coleta $23 / 04 / 2003$} \\
\hline & Afluente & $\begin{array}{c}\text { Efluente } \\
\text { LS-1 }\end{array}$ & $\begin{array}{c}\text { Efluente } \\
\text { LS-2 }\end{array}$ \\
\hline $\mathrm{DQO}(\mathrm{mg} / \mathrm{L})$ & 743 & 54 & 69 \\
\hline $\mathrm{DBO}(\mathrm{mg} / \mathrm{L})$ & 290 & 19 & 20 \\
\hline Remoção de DQO (\%) & NR & 92,7 & 90,7 \\
\hline Remoção de DBO (\%) & $N R$ & 93,4 & 93,1 \\
\hline $\mathrm{pH}$ & 6,8 & 7,1 & 7,2 \\
\hline Condutividade elétrica $(\mu \mathrm{s} / \mathrm{cm})$ & 656 & 486 & 480 \\
\hline Sólidos Totais (mg/L) & 596 & 431 & 412 \\
\hline Sólidos Fixos (mg/L) & 185 & 255 & 265 \\
\hline Sólidos Voláteis (mg/L) & 411 & 176 & 147 \\
\hline Sólidos Suspensos Totais (mg/L) & 244 & 9 & 15 \\
\hline Sólidos Suspensos Fixos (mg/L) & 18 & 3 & 5 \\
\hline Sólidos Suspensos Voláteis (mg/L) & 226 & 6 & 10 \\
\hline Sólidos Dissolvidos Totais (mg/L) & 352 & 422 & 397 \\
\hline Sólidos Dissolvidos Fixos (mg/L) & 167 & 252 & 260 \\
\hline Sólidos Dissolvidos Voláteis (mg/L) & 185 & 170 & 137 \\
\hline Sol. Sedimentáveis Cone Imhoff (mL/L) - 1 hora & 4,0 & 0,0 & 0,0 \\
\hline Turbidez (UT) & NR & 26,0 & 29,0 \\
\hline Cor (UC) & NR & 42,0 & 51,0 \\
\hline Cloreto (mg Cl'/L) & 52,6 & 41,2 & 40,6 \\
\hline Nitrogênio amoniacal (mg N/L) & 17,9 & 0,16 & 0,18 \\
\hline Nitrato (mg N/L) & 0,29 & 7,71 & 8,76 \\
\hline Nitrito (mg N/L) & 0,10 & 0,28 & 0,39 \\
\hline Nitrogênio Total Kjeldahl (mg N/L) & 26,04 & 5,67 & 8,76 \\
\hline Fosfato Total (mg P/L) & 9,17 & 5,00 & 6,34 \\
\hline Manganês (mg/L) & NR & 0,091 & 0,079 \\
\hline Ferro $(\mathrm{mg} / \mathrm{L})$ & NR & 2,674 & 2,982 \\
\hline Níquel (mg/L) & NR & 0,021 & 0,042 \\
\hline Zinco (mg/L) & NR & 0,237 & 0,162 \\
\hline Chumbo (mg/L) & NR & 0,203 & 0,356 \\
\hline Cádmio (mg/L) & NR & 0,013 & 0,020 \\
\hline Cobre (Mg/L) & NR & 0,023 & 0,017 \\
\hline Cromo (mg/L) & NR & 0,232 & 0,290 \\
\hline Cobalto (mg/L) & NR & 0,045 & 0,030 \\
\hline
\end{tabular}

NR - Não realizado. 
Tabela 5.25 - Caracterização das amostras do afluente e efluente da ETE-Piloto, coletadas no dia 30/04/2003.

\begin{tabular}{|c|c|c|c|}
\hline \multirow[b]{2}{*}{ Parâmetros } & \multicolumn{3}{|c|}{ Coleta 30/04/2003 } \\
\hline & Afluente & $\begin{array}{c}\text { Efluente } \\
\text { LS-1 }\end{array}$ & $\begin{array}{c}\text { Efluente } \\
\text { LS-2 }\end{array}$ \\
\hline $\mathrm{DQO}(\mathrm{mg} / \mathrm{L})$ & 743 & 52 & 68 \\
\hline $\mathrm{DBO}(\mathrm{mg} / \mathrm{L})$ & 346 & 18 & 22 \\
\hline Remoção de DQO (\%) & NR & 93,0 & 91 \\
\hline Remoção de DBO (\%) & NR & 94,8 & 93,6 \\
\hline $\mathrm{pH}$ & 7,0 & 7,2 & 7,2 \\
\hline Condutividade elétrica $(\mu \mathrm{s} / \mathrm{cm})$ & 748 & 564 & 572 \\
\hline Sólidos Totais (mg/L) & 716 & 374 & 397 \\
\hline Sólidos Fixos (mg/L) & 228 & 260 & 278 \\
\hline Sólidos Voláteis (mg/L) & 488 & 114 & 119 \\
\hline Sólidos Suspensos Totais (mg/L) & 235 & 7 & 15 \\
\hline Sólidos Suspensos Fixos (mg/L) & 19 & 2 & 4 \\
\hline Sólidos Suspensos Voláteis (mg/L) & 216 & 5 & 11 \\
\hline Sólidos Dissolvidos Totais (mg/L) & 481 & 367 & 382 \\
\hline Sólidos Dissolvidos Fixos (mg/L) & 209 & 258 & 274 \\
\hline Sólidos Dissolvidos Voláteis (mg/L) & 272 & 109 & 108 \\
\hline Sol. Sedimentáveis Cone Imhoff $(\mathrm{mL} / \mathrm{L})$ - 1 hora & 5,0 & 0,0 & 0,0 \\
\hline Turbidez (UT) & NR & 17,0 & 24,0 \\
\hline Cor (UC) & NR & 30,0 & 36,0 \\
\hline Cloreto (mg Cl`/L) & 42,1 & 43,6 & 44,1 \\
\hline Nitrogênio amoniacal (mg N/L) & 18,1 & 0,14 & 0,16 \\
\hline Nitrato (mg N/L) & 0,16 & 9,5 & 9,15 \\
\hline Nitrito (mg N/L) & 0,11 & 0,30 & 0,41 \\
\hline Nitrogênio Total Kjeldahl (mg N/L) & 28,56 & 4,98 & 10,20 \\
\hline Fosfato Total (mg P/L) & 11,76 & 5,20 & 6,74 \\
\hline
\end{tabular}

NR - Não realizado. 
Tabela 5.26 - Caracterização das amostras do afluente e efluente da ETE-Piloto, coletadas no dia 07/05/2003.

\begin{tabular}{|c|c|c|c|}
\hline \multirow[b]{2}{*}{ Parâmetros } & \multicolumn{3}{|c|}{ Coleta 07/05/2003 } \\
\hline & Afluente & $\begin{array}{c}\text { Efluente } \\
\text { LS-1 }\end{array}$ & $\begin{array}{c}\text { Efluente } \\
\text { LS-2 }\end{array}$ \\
\hline $\mathrm{DQO}(\mathrm{mg} / \mathrm{L})$ & 759 & 46 & 53 \\
\hline $\mathrm{DBO}(\mathrm{mg} / \mathrm{L})$ & 349 & 16 & 17 \\
\hline Remoção de DQO (\%) & $N R$ & 93,9 & 93,0 \\
\hline Remoção de DBO (\%) & $N R$ & 95,4 & 95,1 \\
\hline $\mathrm{PH}$ & 7,1 & 7,30 & 7,2 \\
\hline Condutividade elétrica ( $\mu \mathrm{s} / \mathrm{cm})$ & 744 & 578 & 580 \\
\hline Sólidos Totais (mg/L) & 399 & 355 & 388 \\
\hline Sólidos Fixos (mg/L) & 202 & 245 & 260 \\
\hline Sólidos Voláteis (mg/L) & 197 & 110 & 128 \\
\hline Sólidos Suspensos Totais (mg/L) & 250 & 7 & 16 \\
\hline Sólidos Suspensos Fixos (mg/L) & 90 & 2 & 4 \\
\hline Sólidos Suspensos Voláteis (mg/L) & 160 & 5 & 12 \\
\hline Sólidos Dissolvidos Totais (mg/L) & 149 & 348 & 372 \\
\hline Sólidos Dissolvidos Fixos (mg/L) & 166 & 243 & 256 \\
\hline Sólidos Dissolvidos Voláteis (mg/L) & 37 & 105 & 116 \\
\hline Sol. Sedimentáveis Cone Imhoff (mL/L) - 1 hora & 4,0 & 0,0 & 0,0 \\
\hline Turbidez (UT) & $N R$ & 18,0 & 22,0 \\
\hline Cor (UC) & NR & 32,0 & 41,0 \\
\hline Cloreto (mg Cl'/L) & 45,0 & 44,8 & 45,1 \\
\hline Nitrogênio amoniacal (mg N/L) & 14,28 & 0,06 & ND \\
\hline Nitrato (mg N/L) & 0,38 & 6,7 & 7,8 \\
\hline Nitrito (mg N/L) & 0,09 & 0,18 & 0,42 \\
\hline Nitrogênio Total Kjeldahl (mg N/L) & 25,35 & 4,67 & 9,64 \\
\hline Fosfato Total (mg P/L) & 9,10 & 4,89 & 5,91 \\
\hline
\end{tabular}

NR - Não realizado. 
Tabela 5.27 - Caracterização das amostras do afluente e efluente da ETE-Piloto, coletadas no dia 14/05/2003.

\begin{tabular}{|c|c|c|c|}
\hline \multirow[b]{2}{*}{ Parâmetros } & \multicolumn{3}{|c|}{ Coleta $14 / 05 / 2003$} \\
\hline & Afluente & $\begin{array}{c}\text { Efluente } \\
\text { LS-1 }\end{array}$ & $\begin{array}{c}\text { Efluente } \\
\text { LS-2 }\end{array}$ \\
\hline $\mathrm{DQO}(\mathrm{mg} / \mathrm{L})$ & 739 & 43 & 53 \\
\hline $\mathrm{DBO}(\mathrm{mg} / \mathrm{L})$ & 312 & 26 & 28 \\
\hline Remoção de DQO (\%) & NR & 94,1 & 92,9 \\
\hline Remoção de DBO (\%) & NR & 91,7 & 91,2 \\
\hline $\mathrm{pH}$ & 6,9 & 7,4 & 7,3 \\
\hline Condutividade elétrica $(\mu \mathrm{s} / \mathrm{cm})$ & 453 & 680 & 673 \\
\hline Sólidos Totais (mg/L) & 766 & 321 & 384 \\
\hline Sólidos Fixos (mg/L) & 218 & 221 & 270 \\
\hline Sólidos Voláteis (mg/L) & 548 & 100 & 114 \\
\hline Sólidos Suspensos Totais (mg/L) & 267 & 6 & 14 \\
\hline Sólidos Suspensos Fixos (mg/L) & 38 & 1 & 4 \\
\hline Sólidos Suspensos Voláteis (mg/L) & 229 & 5 & 10 \\
\hline Sólidos Dissolvidos Totais (mg/L) & 499 & 315 & 370 \\
\hline Sólidos Dissolvidos Fixos (mg/L) & 180 & 220 & 266 \\
\hline Sólidos Dissolvidos Voláteis (mg/L) & 319 & 95 & 104 \\
\hline Sol. Sedimentáveis Cone Imhoff (mL/L) - 1 hora & 1,0 & 0,0 & 0,0 \\
\hline Turbidez (UT) & NR & 22,0 & 23,0 \\
\hline Cor (UC) & NR & 36,0 & 39,0 \\
\hline Cloreto (mg Cl$/ / L)$ & 58,4 & 52,6 & 51,7 \\
\hline Nitrogênio amoniacal (mg N/L) & 16,30 & ND & ND \\
\hline Nitrato (mg N/L) & 0,47 & 4,72 & 8,51 \\
\hline Nitrito (mg N/L) & 0,20 & 0,15 & 0,46 \\
\hline Nitrogênio Total Kjeldahl (mg N/L) & 27,72 & 5,04 & 12,60 \\
\hline Fosfato Total (mg P/L) & 7,36 & 5,31 & 6,53 \\
\hline Manganês (mg/L) & 0,138 & 0,054 & 0,062 \\
\hline Ferro (mg/L) & 9,843 & 2,633 & 2,589 \\
\hline Níquel (mg/L) & 0,045 & 0,017 & 0,063 \\
\hline Zinco (mg/L) & 0,981 & 0,156 & 0,106 \\
\hline Chumbo (mg/L) & 0,226 & 0,370 & 0,254 \\
\hline Cádmio (mg/L) & $<0,001$ & 0,014 & 0,008 \\
\hline Cobre $(\mathrm{Mg} / \mathrm{L})$ & 0,067 & 0,020 & 0,020 \\
\hline Cromo (mg/L) & 0,165 & 0,251 & 0,252 \\
\hline Cobalto (mg/L) & 0,046 & 0,030 & 0,031 \\
\hline Coliformes Totais (x $\left.10^{4} \mathrm{NMP} / 100 \mathrm{~mL}\right)$ & NR & 4,10 & 3,30 \\
\hline Escherichia coli (x 10² NMP/100mL) & NR & 1,28 & 1,38 \\
\hline
\end{tabular}

NR - Não realizado. 


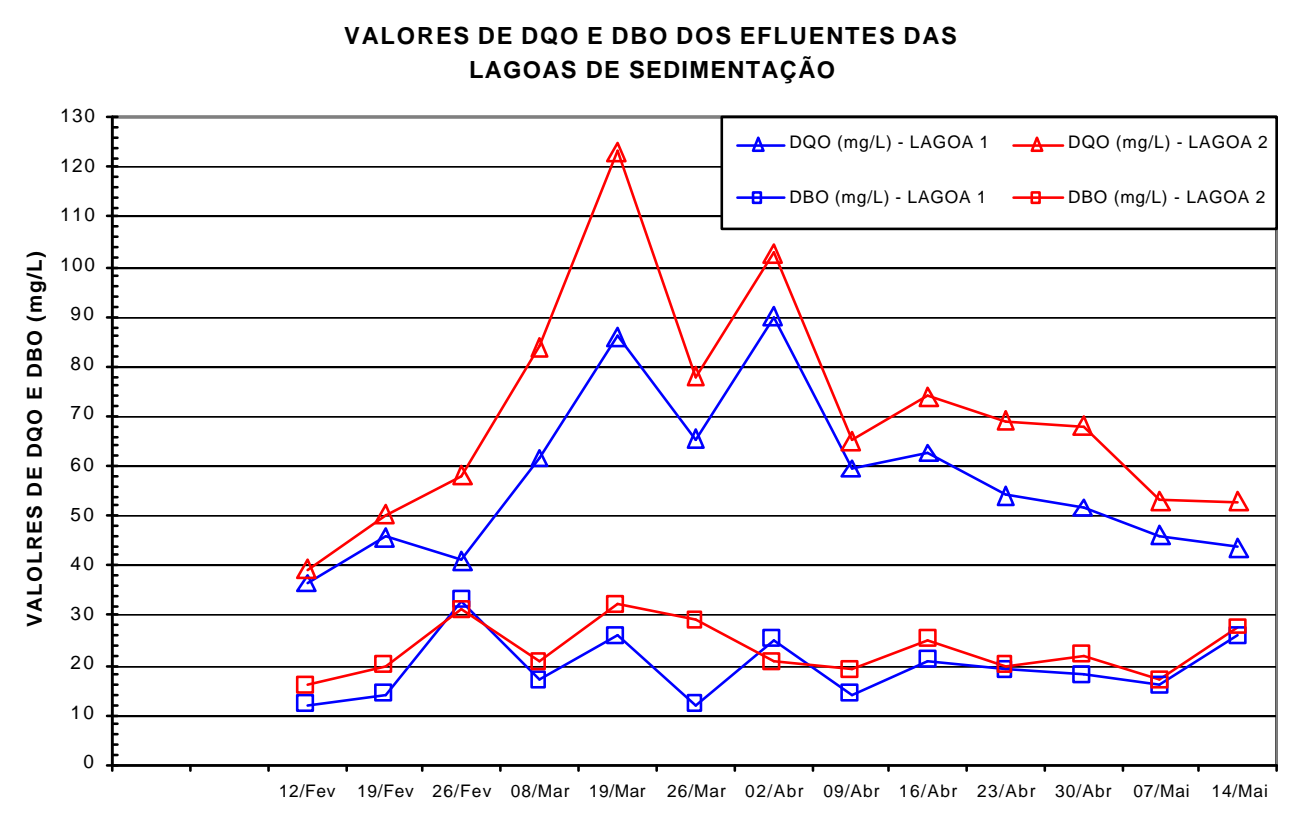

DIA DA COLETA

Figura 5.15 - Valores de DQO e DBO nos efluentes das lagoas de sedimentação durante o período de operação das ETEs-piloto. Lagoa 1 pertecente ao conjunto que recebeu resíduo da ETA-Fonte. Lagoa 2 pertencente ao conjunto que não recebeu resíduo da ETA-Fonte.

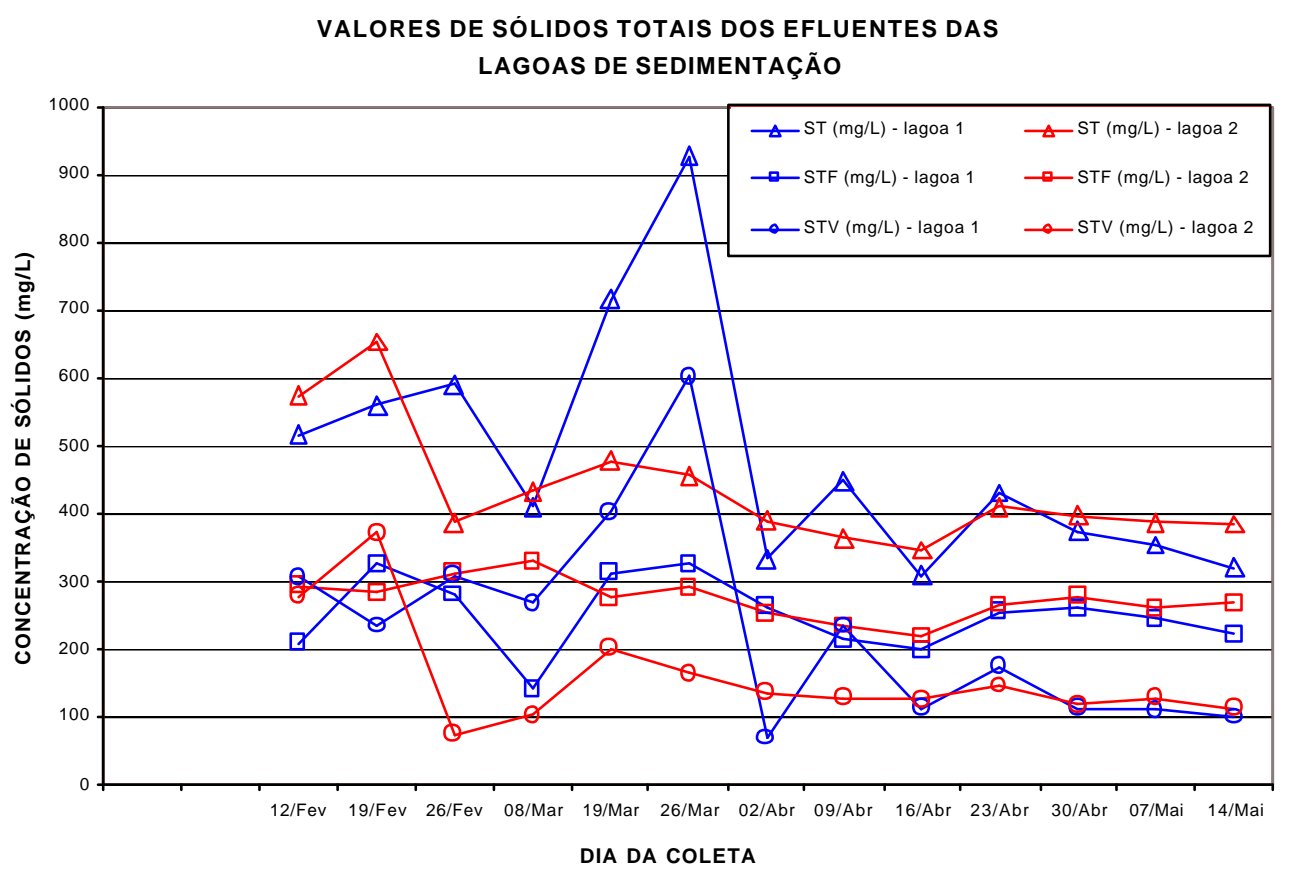

Figura 5.16 - Concentração de Sólidos Totais (ST), Sólidos Fixos (SF) e Sólidos Voláteis (SV) nos efluentes das lagoas de sedimentação durante o período de operação das ETEs-piloto. Lagoa 1 pertecente ao conjunto que recebeu resíduo da ETA-Fonte. Lagoa 2 pertencente ao conjunto que não recebeu resíduo da ETAFonte. 
VALORES DE SOLIDOS DISSOLVIDOS DOS EFLUENTES DAS LAGOAS DE SEDIMENTAÇÃO

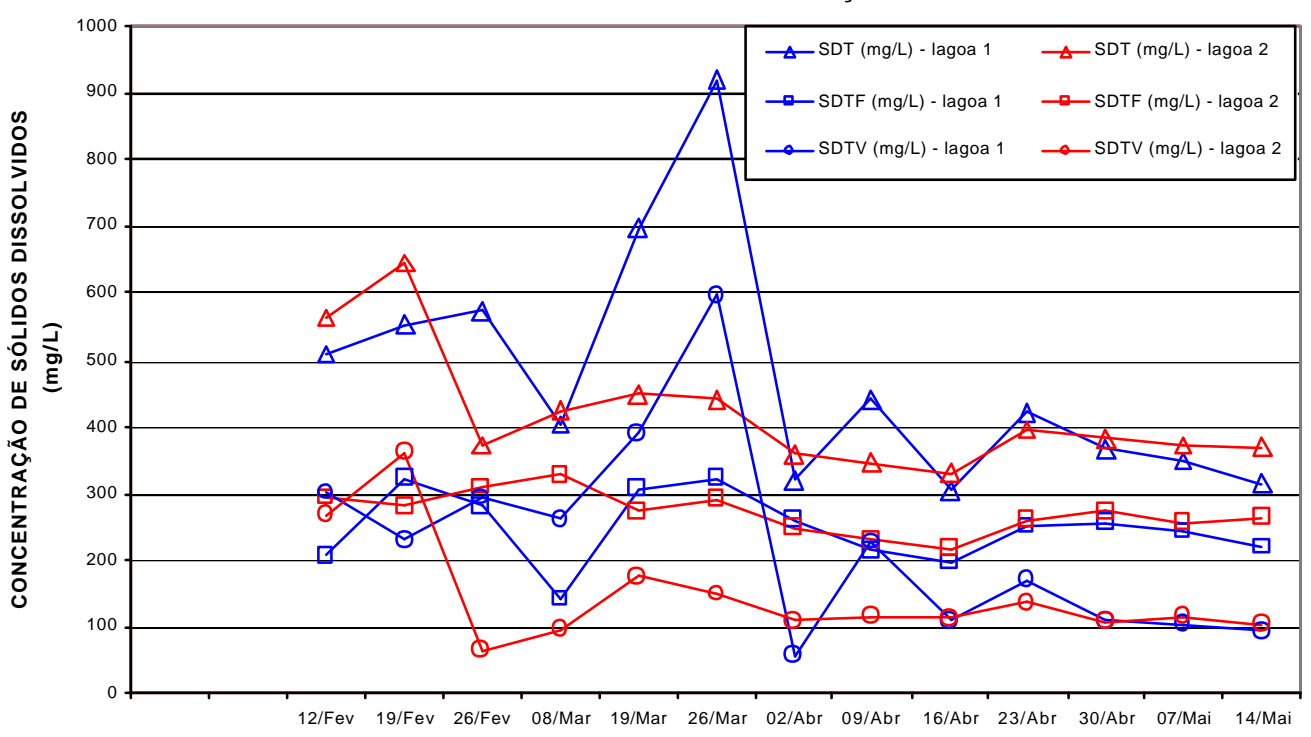

DIA DA COLETA

Figura 5.17 - Concentração SDT, SDF e SDV nos efluentes das lagoas de sedimentação durante o período de operação das ETEs-piloto. Lagoa 1 pertecente ao conjunto que recebeu resíduo da ETA-Fonte. Lagoa 2 pertencente ao conjunto que não recebeu resíduo da ETA-Fonte.

VALORES DE SOLLIDOS SUSPENSOS DOS EFLUENTES

DAS LAGOAS DE SEDIMENTAÇ̃̃O

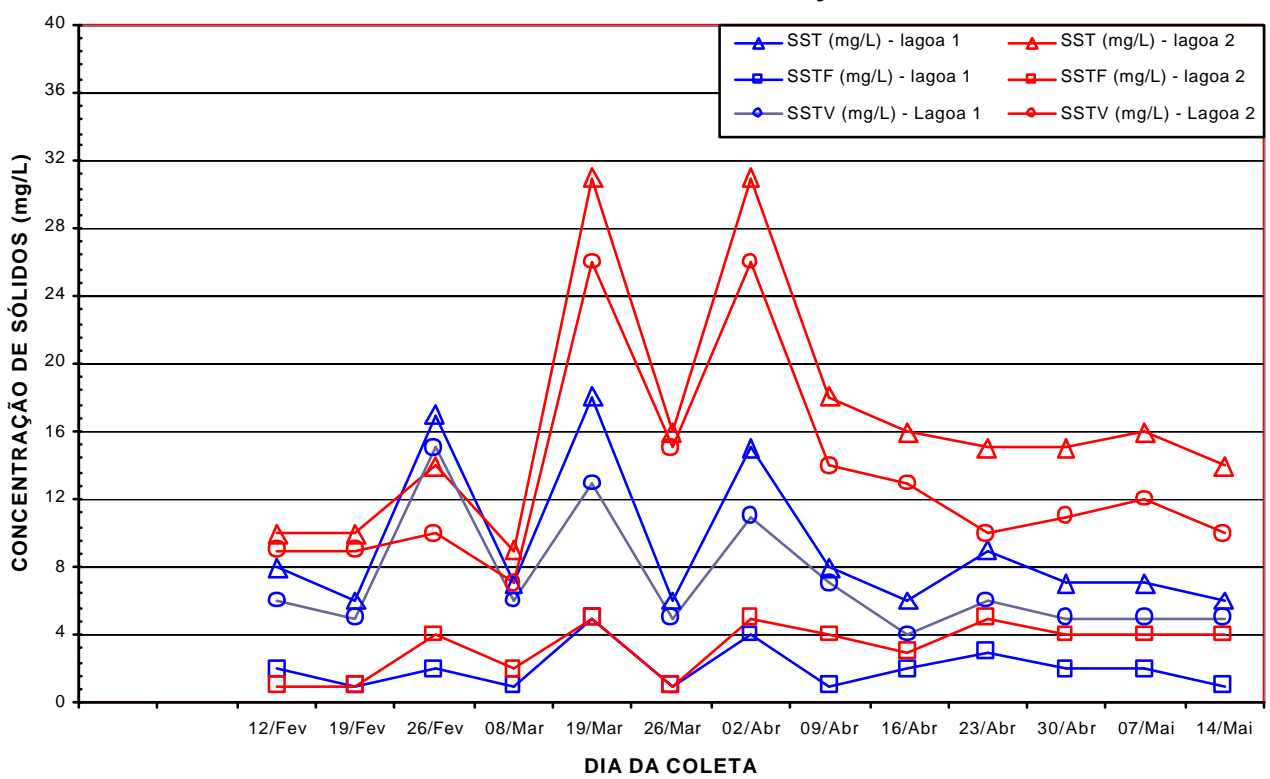

Figura 5.18 - Concentração de SST, SSF e SSV nos efluentes das lagoas de sedimentação durante o período de operação das ETEs-piloto. Lagoa 1 pertecente ao conjunto que recebeu resíduo da ETA-Fonte. Lagoa 2 pertencente ao conjunto que não recebeu resíduo da ETA-Fonte. 


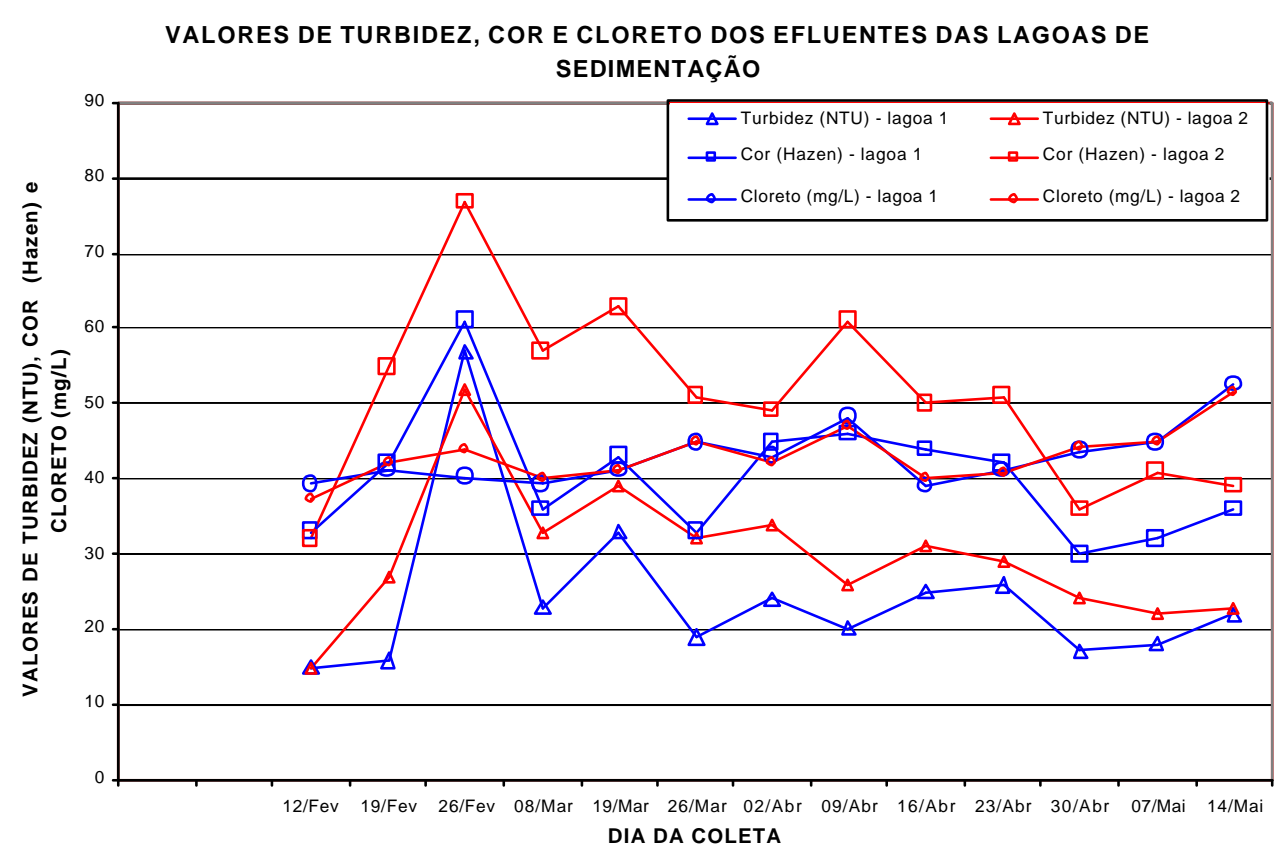

Figura 5.19 - Valores de Turbidez, Cor aparente e concentração de Cloreto nos efluentes das lagoas de sedimentação durante o período de operação das ETEspiloto. Lagoa 1 pertecente ao conjunto que recebeu resíduo da ETA-Fonte. Lagoa 2 pertencente ao conjunto que não recebeu resíduo da ETA-Fonte.

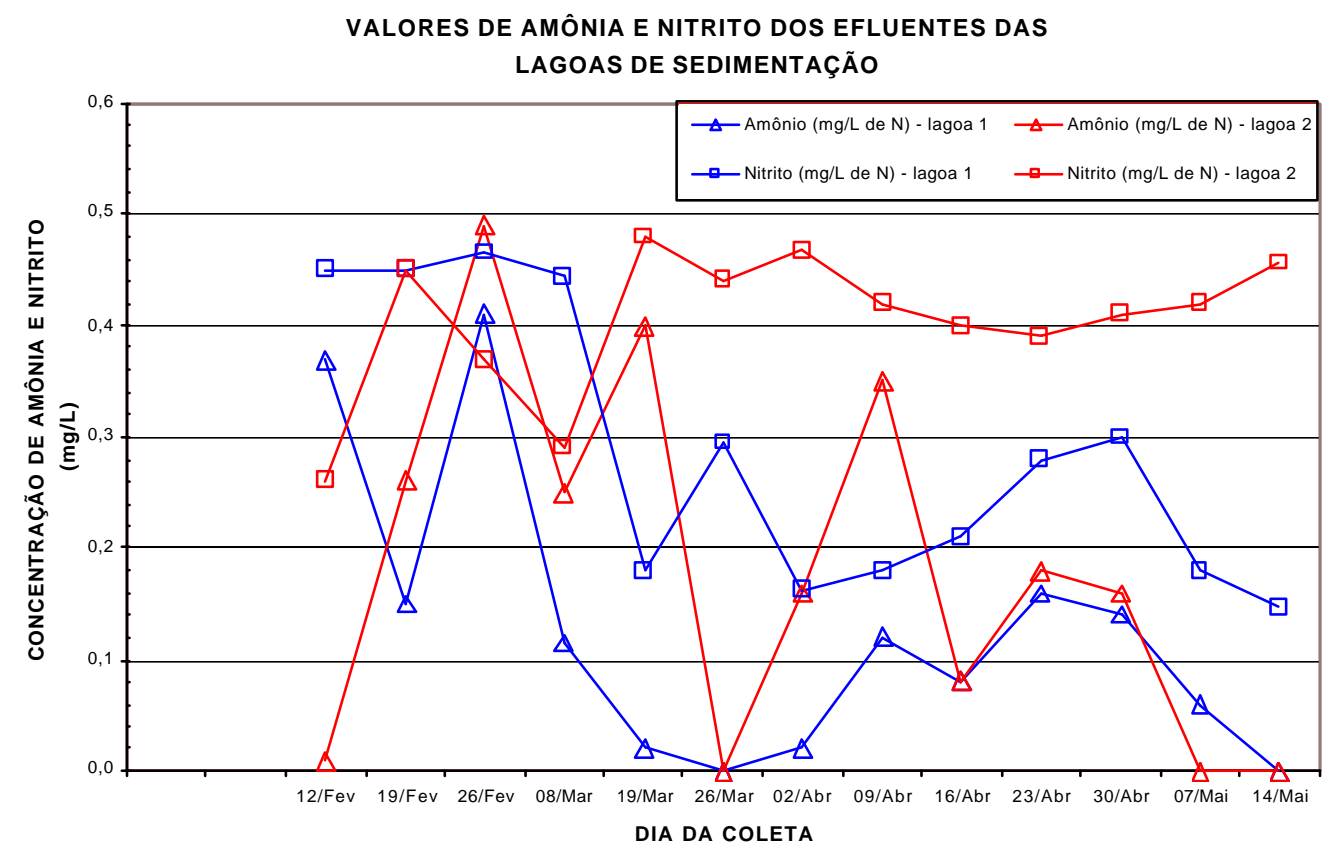

Figura 5.20 - Concentração de Nitrogênio amoniacal e Nitrito nos efluentes das lagoas de sedimentação durante o período de operação das ETEs-piloto. Lagoa 1 pertecente ao conjunto que recebeu resíduo da ETA-Fonte. Lagoa 2 pertencente ao conjunto que não recebeu resíduo da ETA-Fonte. 
VALORES DE NITRATO, NITROGËNIO KJELDAHL E FOSFATO TOTAL DOS EFLUENTES DAS LAGOAS DE SEDIMENTAÇÃO

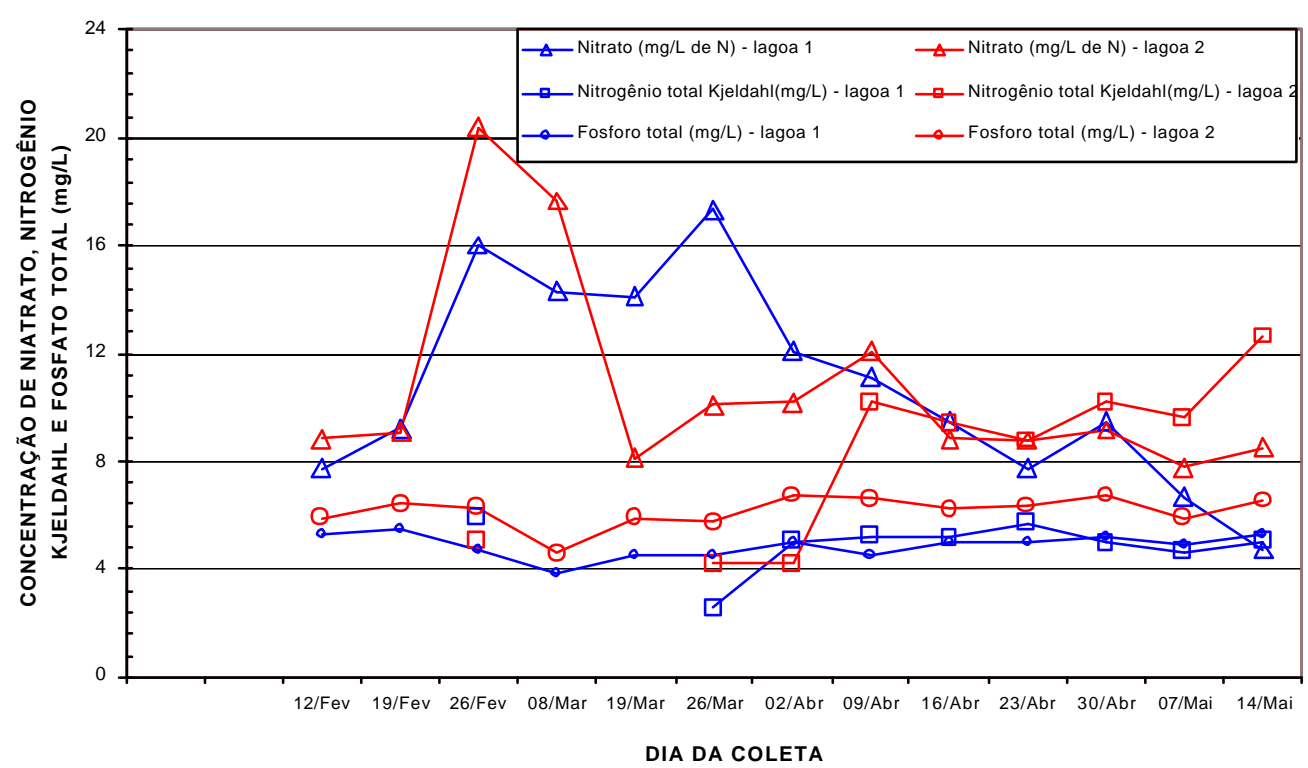

Figura 5.21 - Concentração de Nitrato, NTK e Fosfato total nos efluentes das lagoas de sedimentação durante o período de operação das ETEs-piloto. Lagoa 1 pertecente ao conjunto que recebeu resíduo da ETA-Fonte. Lagoa 2 pertencente ao conjunto que não recebeu resíduo da ETA-Fonte.

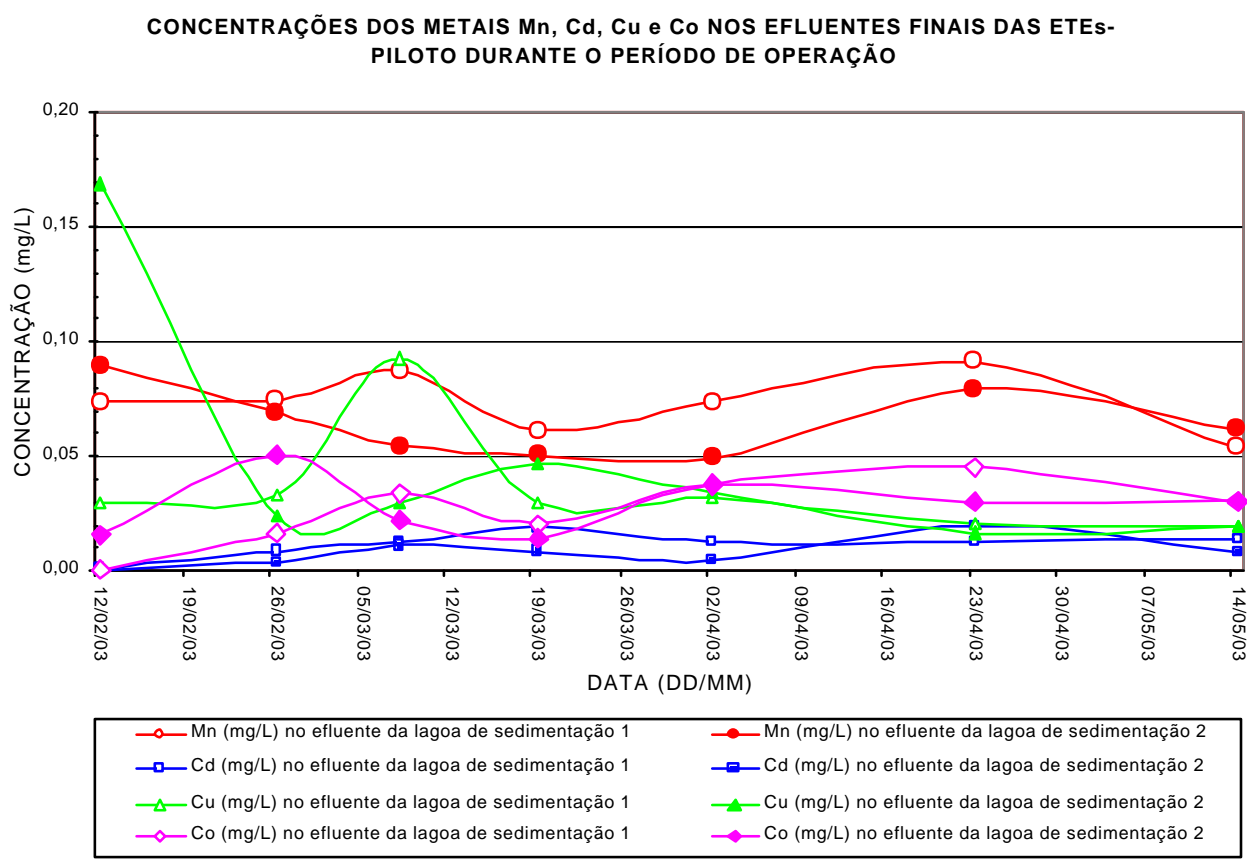

Figura 5.22 - Concentrações dos metais $\mathrm{Mn}, \mathrm{Cd}, \mathrm{Cu}$ e Co nos efluentes finais durante o período de operação das ETEs-piloto. Lagoa 1 pertecente ao conjunto que recebeu resíduo da ETA-Fonte. Lagoa 2 pertencente ao conjunto que não recebeu resíduo da ETA-Fonte. 


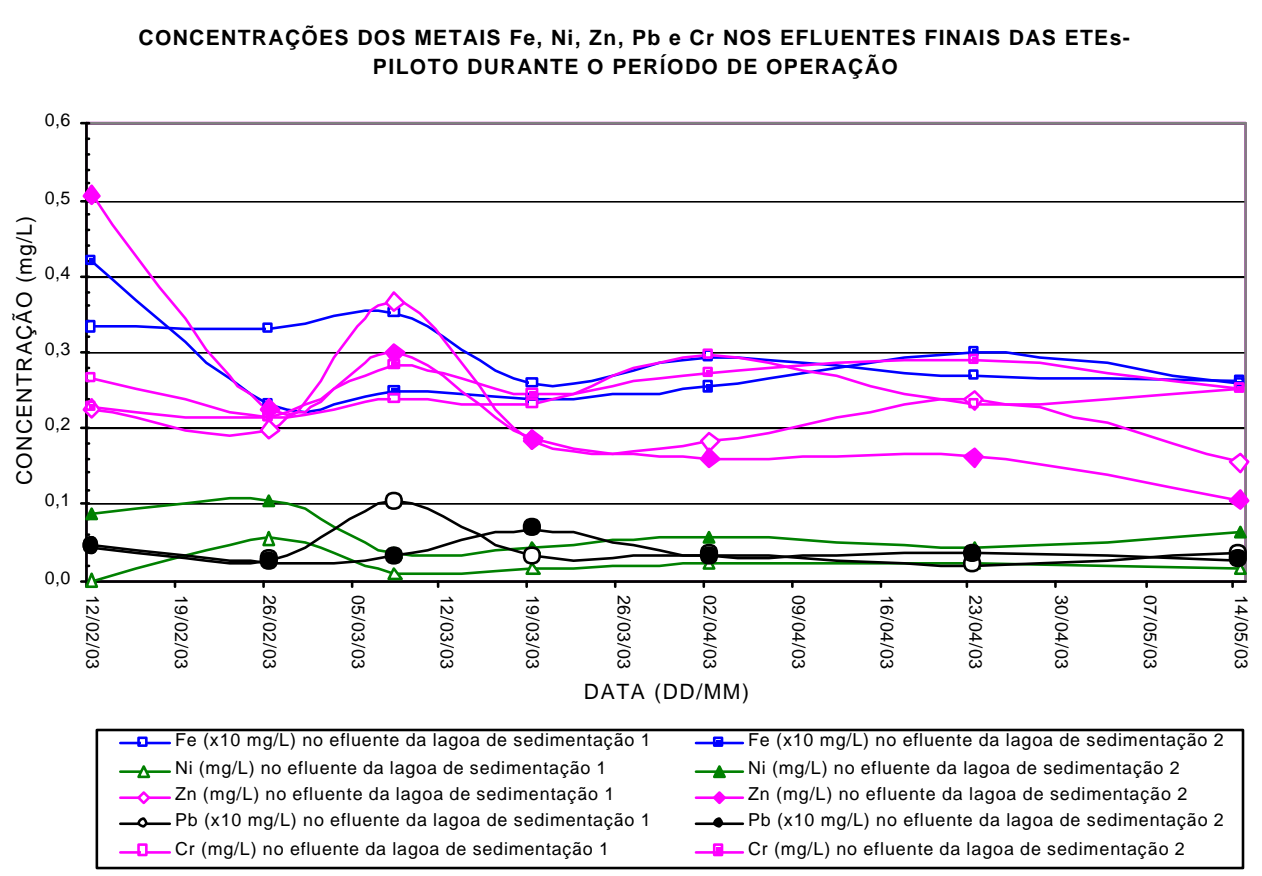

Figura 5.23 - Concentrações dos metais $\mathrm{Fe}, \mathrm{Ni}, \mathrm{Zn}, \mathrm{Pb}$ e $\mathrm{Cr}$ nos efluentes finais durante o período de operação das ETEs-piloto. Lagoa 1 pertencente ao conjunto que recebeu resíduo da ETA-Fonte. Lagoa 2 pertencente ao conjunto que não recebeu resíduo da ETA-Fonte.

\subsection{Taxa de Consumo de Oxigênio e Caracterização do Licor das Lagoas de Aeração}

Foram realizados dois ensaios para determinação das taxas de consumo de oxigênio nos licores mistos das lagoas de aeração, sendo que os valores de OD foram medidos, com auxílio de um oxímetro, em intervalos de 1 minuto, estando registrados nas tabelas 5.29 a 5.32 .

Nota-se, nas figuras 5.26 a 5.29 , que as correlações das retas aos pontos experimentais foram boas, atingindo valores superiores a 99,6 \%, e as taxas de consumo de oxigênio, que são determinadas pelos coeficientes angulares das retas, foram maiores na lagoa de aeração 2, que não recebeu resíduo da ETAFonte. Os valores determinados para as taxas de consumo de oxigênio estão contidos na tabela 5.28.

O menor consumo de oxigênio foi observado na lagoa de aeração 1, estando associado a presença do resíduo da ETA-Fonte, que interferiu de alguma forma, seja por inibição ou por diminuição da quantidade de microrganismos. 
Relacionando $\mathrm{TCO}_{\mathrm{a}}$ com a quantidade de SSV presentes no licor misto foram obtidos valores inferiores para os ensaios com o licor da lagoa de aeração 1, indicando que os organismos presentes, representados pelos SSV, não consumiram oxigênio da mesma forma que na lagoa 2 .

Antes do ensaio para determinação da $\mathrm{TCO}_{\mathrm{a}}$, apesar da vazão de ar introduzida nas duas lagoas de aeração terem sido a mesma, os teores de OD na lagoa de aeração 1 foram maiores que na lagoa 2, isto indica que o resíduo da ETA adicionado interferiu nos sistema. Isto não pode ser considerado ruim pois não interferiu na qualidade do efluente.

Portanto, a menor $\mathrm{TCO}_{a}$ e a menor relação $\mathrm{TCO}_{a} /$ SSV na lagoa de aeração 1, indica que o resíduo da ETA-Fonte promoveu redução tanto na quantidade de microrganismos como na taxa de consumo de oxigênio.

$\mathrm{Na}$ tabela 5.28 além dos valores da $\mathrm{TCO}_{\mathrm{a}}$ estão presentes os resultados da caracterização realizada do material.

Os sólidos sedimentáveis, presentes na lagoa que recebeu resíduo da ETAFonte, foram superiores aos encontrados na lagoa de aeração que não recebeu o resíduo. No entanto, os ST, representados em sua maior totalidade pelos SDT, foram superiores na lagoa 2.

Em relação aos SST a lagoa 1 apresentou maior concentração na forma de SSF, ao contrário da lagoa 2 que apresentou maior concentração de SSV.

Observa-se, na tabela 5.28, que dentre os metais pesquisados no licor misto das lagoas de aeração, o Ferro foi o que apresentou maior divergência entre as duas lagoas, sendo encontrado em maior concentração na lagoa 1, representando cerca de $174 \%$ em relação à lagoa que não recebeu resíduo da ETA-Fonte. Isto ocorreu devido ao resíduo da ETA-Fonte, adicionado ao sistema, apresentar

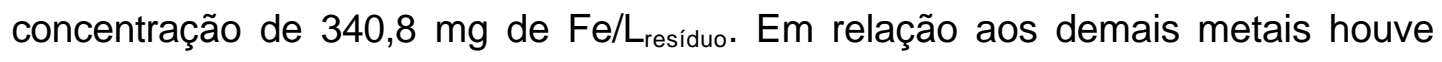
diferenças mas nenhuma tão expressiva como a do Ferro. 
Tabela 5.28 - Nesta tabela estão contidos os resultados da $\mathrm{TCO}_{\mathrm{a}}$ nos licores mistos das lagoas de aeração e as relações $\mathrm{TCO}_{\mathrm{a}} / \mathrm{SSV}$, juntamente com o resultado de alguns parâmetros pesquisados.

\begin{tabular}{|c|c|c|c|c|}
\hline \multirow[t]{2}{*}{ Parâmetros } & \multicolumn{2}{|c|}{$\begin{array}{l}\text { Licor misto da Lagoa } \\
\text { de Aeração que } \\
\text { recebeu resíduo da } \\
\text { ETA-Fonte. }\end{array}$} & \multicolumn{2}{|c|}{$\begin{array}{l}\text { Licor misto da Lagoa } \\
\text { de Aeração que não } \\
\text { recebeu resíduo da } \\
\text { ETA-Fonte. }\end{array}$} \\
\hline & $02 / 05 / 03$ & $14 / 05 / 03$ & $02 / 05 / 03$ & $14 / 05 / 03$ \\
\hline $\mathrm{TCO}_{\mathrm{a}}\left(\mathrm{TCO}_{\mathrm{a}} \mathrm{mg} / \mathrm{L} . \mathrm{h}\right)$ & 1,61 & 1,70 & 2,32 & 2,64 \\
\hline $\mathrm{TCO}_{\mathrm{a}} / \mathrm{SSV}\left(\mathrm{mgO}_{2} / \mathrm{L} . \mathrm{h}\right) /(\mathrm{mgSSV} / \mathrm{L}$ licor $)$ & $8,9 \times 10^{-3}$ & $9,3 \times 10^{-3}$ & $10,8 \times 10^{-3}$ & $11,2 \times 10^{-3}$ \\
\hline $\mathrm{DQO}(\mathrm{mg} / \mathrm{L})$ & 361 & 388 & 526 & 572 \\
\hline $\mathrm{pH}$ & 7,1 & 7,2 & 7,1 & 7,3 \\
\hline $\mathrm{OD}(\mathrm{mg} / \mathrm{L})$ & 3,10 & 3,20 & 2,75 & 2,90 \\
\hline Condutividade elétrica $(\mu \mathrm{s} / \mathrm{cm})$ & 525 & 545 & 540 & 536 \\
\hline Sólidos Totais (mg/L) & 790 & 856 & 950 & 1046 \\
\hline Sólidos Fixos (mg/L) & NR & 484 & NR & 520 \\
\hline Sólidos Voláteis (mg/L) & NR & 372 & NR & 526 \\
\hline Sólidos Suspensos Totais (mg/L) & 374 & 393 & 401 & 397 \\
\hline Sólidos Suspensos Fixos (mg/L) & NR & 210 & NR & 161 \\
\hline Sólidos Suspensos Voláteis (mg/L) & NR & 183 & NR & 235 \\
\hline Sólidos Dissolvidos Totais (mg/L) & 416 & 463 & 549 & 649 \\
\hline Sólidos Dissolvidos Fixos (mg/L) & NR & 274 & NR & 359 \\
\hline Sólidos Dissolvidos Voláteis (mg/L) & NR & 189 & NR & 291 \\
\hline Sol. Sed. em Cone Imhoff $(\mathrm{mL} / \mathrm{L})$ - 1 hora & 15,5 & 16,0 & 13,0 & 13,5 \\
\hline Mn (mg Mn/g SST) & NR & 1,376 & NR & 0,931 \\
\hline $\mathrm{Fe}(\mathrm{mg} \mathrm{Fe} / \mathrm{g} \mathrm{SST})$ & NR & 99,568 & NR & 35,914 \\
\hline $\mathrm{Ni}(\mathrm{mg} \mathrm{Ni} / \mathrm{g} \mathrm{SST})$ & NR & 1,068 & NR & 1,354 \\
\hline Zn (mg Zn/g SST) & NR & 1,068 & NR & 1,077 \\
\hline $\mathrm{Pb}(\mathrm{mg} \mathrm{Pb} / \mathrm{g} \mathrm{SST})$ & NR & 0,483 & NR & 0,641 \\
\hline $\mathrm{Cd}(\mathrm{mg} \mathrm{Cd} / \mathrm{g} \mathrm{SST})$ & NR & $<0,001$ & $N R$ & $<0,001$ \\
\hline $\mathrm{Cu}(\mathrm{mg} \mathrm{Cu} / \mathrm{g} \mathrm{SST})$ & NR & 0,333 & NR & 0,390 \\
\hline $\mathrm{Cr}$ (mg Cr/g SST) & NR & 1,913 & NR & 2,087 \\
\hline Co (mg Co/g SST) & NR & 0,168 & NR & 0,128 \\
\hline
\end{tabular}

NR - Não realizado. 
Tabela 5.29 - Valores de OD em função do tempo, obtidos durante o ensaio para determinação da taxa de consumo de oxigênio na Lagoa de Aeração que recebeu resíduo da ETA-Fonte. Ensaio realizado no 02 de maio de 2003.

\begin{tabular}{|c|c|c|c|c|c|c|c|c|c|}
\hline $\begin{array}{c}\text { Tempo } \\
(\mathrm{min})\end{array}$ & $\begin{array}{c}\mathrm{OD} \\
(\mathrm{mg} / \mathrm{L})\end{array}$ & $\begin{array}{c}\text { Tempo } \\
\text { (min) }\end{array}$ & $\begin{array}{c}\text { OD } \\
(\mathrm{mg} / \mathrm{L})\end{array}$ & $\begin{array}{c}\text { Tempo } \\
\text { (min) }\end{array}$ & $\begin{array}{c}\text { OD } \\
(\mathrm{mg} / \mathrm{L})\end{array}$ & $\begin{array}{c}\text { Tempo } \\
\text { (min) }\end{array}$ & $\begin{array}{c}\mathrm{OD} \\
(\mathrm{mg} / \mathrm{L})\end{array}$ & $\begin{array}{c}\text { Tempo } \\
\text { (min) }\end{array}$ & $\begin{array}{c}\mathrm{OD} \\
(\mathrm{mg} / \mathrm{L})\end{array}$ \\
\hline 0,00 & 7,10 & 35,00 & 5,43 & 82,00 & 4,38 & 129,00 & 3,56 & 176,00 & 2,75 \\
\hline 0,25 & 6,67 & 36,00 & 5,42 & 83,00 & 4,35 & 130,00 & 3,55 & 177,00 & 2,73 \\
\hline 0,50 & 6,60 & 37,00 & 5,40 & 84,00 & 4,35 & 131,00 & 3,52 & 178,00 & 2,68 \\
\hline 0,75 & 6,57 & 38,00 & 5,37 & 85,00 & 4,37 & 132,00 & 3,50 & 179,00 & 2,73 \\
\hline 1,00 & 6,47 & 39,00 & 5,36 & 86,00 & 4,36 & 133,00 & 3,49 & 180,00 & 2,70 \\
\hline 1,50 & 6,46 & 40,00 & 5,34 & 87,00 & 4,34 & 134,00 & 3,46 & 181,00 & 2,68 \\
\hline 2,00 & 6,41 & 41,00 & 5,30 & 88,00 & 4,28 & 135,00 & 3,42 & 182,00 & 2,67 \\
\hline 2,50 & 6,38 & 42,00 & 5,26 & 89,00 & 4,25 & 136,00 & 3,41 & 183,00 & 2,66 \\
\hline 3,00 & 3,40 & 43,00 & 5,26 & 90,00 & 4,25 & 137,00 & 3,39 & 184,00 & 2,65 \\
\hline 3,50 & 6,35 & 44,00 & 5,24 & 91,00 & 4,24 & 138,00 & 3,37 & 185,00 & 2,64 \\
\hline 4,00 & 6,26 & 45,00 & 5,20 & 92,00 & 4,22 & 139,00 & 3,37 & 186,00 & 2,63 \\
\hline 4,50 & 6,31 & 46,00 & 5,18 & 93,00 & 4,22 & 140,00 & 3,32 & 187,00 & 2,62 \\
\hline 5,00 & 6,28 & 47,00 & 5,16 & 94,00 & 4,18 & 141,00 & 3,30 & 188,00 & 2,60 \\
\hline 5,50 & 6,29 & 48,00 & 5,15 & 95,00 & 4,17 & 142,00 & 3,30 & 189,00 & 2,58 \\
\hline 6,00 & 6,26 & 49,00 & 5,10 & 96,00 & 4,16 & 143,00 & 3,28 & 190,00 & 2,57 \\
\hline 6,50 & 6,19 & 50,00 & 5,08 & 97,00 & 4,15 & 144,00 & 3,25 & 191,00 & 2,58 \\
\hline 7,00 & 6,22 & 51,00 & 5,05 & 98,00 & 4,10 & 145,00 & 3,24 & 192,00 & 2,61 \\
\hline 7,50 & 6,15 & 52,00 & 4,99 & 99,00 & 4,11 & 146,00 & 3,20 & 193,00 & 2,57 \\
\hline 8,00 & 6,17 & 53,00 & 5,01 & 100,00 & 4,05 & 147,00 & 3,16 & 194,00 & 2,55 \\
\hline 8,50 & 6,19 & 54,00 & 4,98 & 101,00 & 4,06 & 148,00 & 3,15 & 195,00 & 2,51 \\
\hline 9,00 & 6,15 & 55,00 & 4,94 & 102,00 & 4,01 & 149,00 & 3,16 & 196,00 & 2,55 \\
\hline 9,50 & 6,10 & 56,00 & 4,91 & 103,00 & 4,04 & 150,00 & 3,11 & 197,00 & 2,54 \\
\hline 10,00 & 6,11 & 57,00 & 4,91 & 104,00 & 4,01 & 151,00 & 3,07 & 198,00 & 2,55 \\
\hline 11,00 & 6,04 & 58,00 & 4,86 & 105,00 & 3,98 & 152,00 & 3,06 & 199,00 & 2,53 \\
\hline 12,00 & 5,95 & 59,00 & 4,84 & 106,00 & 3,96 & 153,00 & 3,07 & 200,00 & 2,54 \\
\hline 13,00 & 6,00 & 60,00 & 4,81 & 107,00 & 3,97 & 154,00 & 3,05 & 201,00 & 2,52 \\
\hline 14,00 & 5,98 & 61,00 & 4,78 & 108,00 & 3,95 & 155,00 & 3,03 & 202,00 & 2,51 \\
\hline 15,00 & 5,85 & 62,00 & 4,81 & 109,00 & 3,88 & 156,00 & 3,03 & 203,00 & 2,53 \\
\hline 16,00 & 5,91 & 63,00 & 4,80 & 110,00 & 3,91 & 157,00 & 3,02 & 204,00 & 2,46 \\
\hline 17,00 & 5,89 & 64,00 & 4,75 & 111,00 & 3,93 & 158,00 & 3,00 & 205,00 & 2,50 \\
\hline 18,00 & 5,85 & 65,00 & 4,73 & 112,00 & 3,90 & 159,00 & 2,98 & 206,00 & 2,51 \\
\hline 19,00 & 5,88 & 66,00 & 4,73 & 113,00 & 3,86 & 160,00 & 2,96 & 207,00 & 2,49 \\
\hline 20,00 & 5,84 & 67,00 & 4,69 & 114,00 & 3,85 & 161,00 & 2,95 & 208,00 & 2,47 \\
\hline 21,00 & 5,81 & 68,00 & 4,67 & 115,00 & 3,84 & 162,00 & 2,94 & 209,00 & 2,46 \\
\hline 22,00 & 5,80 & 69,00 & 4,64 & 116,00 & 3,82 & 163,00 & 2,93 & 210,00 & 2,45 \\
\hline 23,00 & 5,76 & 70,00 & 4,61 & 117,00 & 3,83 & 164,00 & 2,89 & 211,00 & 2,46 \\
\hline 24,00 & 5,73 & 71,00 & 4,61 & 118,00 & 3,79 & 165,00 & 2,90 & 212,00 & 2,47 \\
\hline 25,00 & 5,68 & 72,00 & 4,60 & 119,00 & 3,79 & 166,00 & 2,88 & & \\
\hline 26,00 & 5,65 & 73,00 & 4,56 & 120,00 & 3,76 & 167,00 & 2,89 & & \\
\hline 27,00 & 5,60 & 74,00 & 4,55 & 121,00 & 3,77 & 168,00 & 2,85 & & \\
\hline 28,00 & 5,58 & 75,00 & 4,53 & 122,00 & 3,75 & 169,00 & 2,83 & & \\
\hline 29,00 & 5,55 & 76,00 & 4,53 & 123,00 & 3,71 & 170,00 & 2,80 & & \\
\hline 30,00 & 5,55 & 77,00 & 4,50 & 124,00 & 3,66 & 171,00 & 2,79 & & \\
\hline 31,00 & 5,52 & 78,00 & 4,47 & 125,00 & 3,64 & 172,00 & 2,75 & & \\
\hline 32,00 & 5,47 & 79,00 & 4,46 & 126,00 & 3,64 & 173,00 & 2,74 & & \\
\hline 33,00 & 5,46 & 80,00 & 4,44 & 127,00 & 3,61 & 174,00 & 2,73 & & \\
\hline 34,00 & 5,47 & 81,00 & 4,40 & 128,00 & 3,59 & 175,00 & 2,75 & & \\
\hline
\end{tabular}


Tabela 5.30 - Valores de OD, em função do tempo, obtidos durante o ensaio para determinação da taxa de consumo de oxigênio na Lagoa de Aeração que não recebeu resíduo da ETA-Fonte. Ensaio realizado no dia 02 de maio de 2003.

\begin{tabular}{|c|c|c|c|c|c|}
\hline Tempo & $\mathrm{OD}(\mathrm{mg} / \mathrm{L})$ & Tempo & $\mathrm{OD}(\mathrm{mg} / \mathrm{L})$ & Tempo & $\mathrm{OD}(\mathrm{mg} / \mathrm{L})$ \\
\hline 0,00 & 7,08 & 29,00 & 4,48 & 70,00 & 3,06 \\
\hline 0,25 & 6,58 & 30,00 & 4,43 & 71,00 & 3,02 \\
\hline 0,50 & 6,62 & 31,00 & 4,37 & 72,00 & 2,98 \\
\hline 0,75 & 6,35 & 32,00 & 4,35 & 73,00 & 2,95 \\
\hline 1,00 & 6,19 & 33,00 & 4,29 & 74,00 & 2,94 \\
\hline 1,50 & 6,07 & 34,00 & 4,27 & 75,00 & 2,91 \\
\hline 2,00 & 6,17 & 35,00 & 4,19 & 76,00 & 2,89 \\
\hline 2,50 & 6,15 & 36,00 & 4,06 & 77,00 & 2,87 \\
\hline 3,00 & 6,10 & 37,00 & 4,12 & 78,00 & 2,86 \\
\hline 3,50 & 6,02 & 38,00 & 4,08 & 79,00 & 2,85 \\
\hline 4,00 & 5,91 & 39,00 & 4,01 & 80,00 & 2,85 \\
\hline 4,50 & 5,88 & 40,00 & 3,97 & 81,00 & 2,81 \\
\hline 5,00 & 5,72 & 41,00 & 3,94 & 82,00 & 2,82 \\
\hline 5,50 & 5,70 & 42,00 & 3,91 & 83,00 & 2,80 \\
\hline 6,00 & 5,51 & 43,00 & 3,84 & 84,00 & 2,78 \\
\hline 6,50 & 5,53 & 44,00 & 3,78 & 85,00 & 2,77 \\
\hline 7,00 & 5,41 & 45,00 & 3,74 & 86,00 & 2,75 \\
\hline 7,50 & 5,46 & 46,00 & 3,73 & 87,00 & 2,72 \\
\hline 8,00 & 5,41 & 47,00 & 3,72 & 88,00 & 2,70 \\
\hline 8,50 & 5,38 & 48,00 & 3,64 & 89,00 & 2,68 \\
\hline 9,00 & 5,37 & 49,00 & 3,61 & 90,00 & 2,65 \\
\hline 9,50 & 5,36 & 50,00 & 3,58 & 91,00 & 2,63 \\
\hline 10,00 & 5,31 & 51,00 & 3,54 & 92,00 & 2,60 \\
\hline 11,00 & 5,30 & 52,00 & 3,51 & 93,00 & 2,58 \\
\hline 12,00 & 5,22 & 53,00 & 3,52 & 94,00 & 2,55 \\
\hline 13,00 & 5,21 & 54,00 & 3,46 & 95,00 & 2,51 \\
\hline 14,00 & 5,20 & 55,00 & 3,45 & 96,00 & \\
\hline 15,00 & 5,16 & 56,00 & 3,40 & 97,00 & \\
\hline 16,00 & 5,05 & 57,00 & 3,39 & 98,00 & \\
\hline 17,00 & 4,94 & 58,00 & 3,36 & 99,00 & \\
\hline 18,00 & 4,90 & 59,00 & 3,35 & 100,00 & \\
\hline 19,00 & 4,89 & 60,00 & 3,30 & 101,00 & \\
\hline 20,00 & 4,84 & 61,00 & 3,29 & 102,00 & \\
\hline 21,00 & 4,81 & 62,00 & 3,27 & 103,00 & \\
\hline 22,00 & 4,67 & 63,00 & 3,25 & 104,00 & \\
\hline 23,00 & 4,69 & 64,00 & 3,24 & 105,00 & \\
\hline 24,00 & 4,65 & 65,00 & 3,20 & 106,00 & \\
\hline 25,00 & 4,57 & 66,00 & 3,18 & 107,00 & \\
\hline 26,00 & 4,56 & 67,00 & 3,17 & 108,00 & \\
\hline 27,00 & 4,56 & 68,00 & 3,14 & 109,00 & \\
\hline 28,00 & 4,52 & 69,00 & 3,10 & 110,00 & \\
\hline
\end{tabular}


Tabela 5.31 - Valores de OD em função do tempo, obtidos durante o ensaio para determinação da taxa de consumo de oxigênio na Lagoa de Aeração que recebeu resíduo da ETA-Fonte. Ensaio realizado no 14 de maio de 2003.

\begin{tabular}{|c|c|c|c|c|c|c|c|}
\hline Tempo & $\mathrm{OD}(\mathrm{mg} / \mathrm{L})$ & Tempo & $\mathrm{OD}(\mathrm{mg} / \mathrm{L})$ & Tempo & $\mathrm{OD}(\mathrm{mg} / \mathrm{L})$ & Tempo & $\mathrm{OD}(\mathrm{mg} / \mathrm{L})$ \\
\hline 0,00 & 7,12 & 29,00 & 5,35 & 70,00 & 4,20 & 111,00 & 3,38 \\
\hline 0,25 & 6,78 & 30,00 & 5,24 & 71,00 & 4,19 & 112,00 & 3,37 \\
\hline 0,50 & 6,67 & 31,00 & 5,16 & 72,00 & 4,13 & 113,00 & 3,35 \\
\hline 0,75 & 6,48 & 32,00 & 5,27 & 73,00 & 4,12 & 114,00 & 3,36 \\
\hline 1,00 & 6,46 & 33,00 & 5,18 & 74,00 & 4,11 & 115,00 & 3,33 \\
\hline 1,50 & 6,36 & 34,00 & 5,15 & 75,00 & 4,04 & 116,00 & 3,32 \\
\hline 2,00 & 6,22 & 35,00 & 5,22 & 76,00 & 4,04 & 117,00 & 3,30 \\
\hline 2,50 & 6,18 & 36,00 & 5,06 & 77,00 & 4,00 & 118,00 & 3,29 \\
\hline 3,00 & 6,09 & 37,00 & 5,08 & 78,00 & 4,00 & 119,00 & 3,30 \\
\hline 3,50 & 6,07 & 38,00 & 4,99 & 79,00 & 3,96 & 120,00 & 3,27 \\
\hline 4,00 & 6,05 & 39,00 & 5,02 & 80,00 & 3,89 & 121,00 & 3,28 \\
\hline 4,50 & 6,00 & 40,00 & 5,02 & 81,00 & 3,90 & 122,00 & 3,24 \\
\hline 5,00 & 5,98 & 41,00 & 5,00 & 82,00 & 3,88 & 123,00 & 3,25 \\
\hline 5,50 & 5,95 & 42,00 & 4,90 & 83,00 & 3,85 & 124,00 & 3,23 \\
\hline 6,00 & 6,02 & 43,00 & 4,95 & 84,00 & 3,86 & 125,00 & 3,24 \\
\hline 6,50 & 5,94 & 44,00 & 4,91 & 85,00 & 3,84 & 126,00 & 3,22 \\
\hline 7,00 & 5,91 & 45,00 & 4,80 & 86,00 & 3,81 & 127,00 & 3,20 \\
\hline 7,50 & 5,85 & 46,00 & 4,81 & 87,00 & 3,78 & 128,00 & 3,19 \\
\hline 8,00 & 6,00 & 47,00 & 4,79 & 88,00 & 3,78 & 129,00 & 3,16 \\
\hline 8,50 & 6,02 & 48,00 & 4,74 & 89,00 & 3,76 & 130,00 & 3,18 \\
\hline 9,00 & 5,95 & 49,00 & 4,74 & 90,00 & 3,75 & 131,00 & 3,16 \\
\hline 9,50 & 5,97 & 50,00 & 4,76 & 91,00 & 3,70 & 132,00 & 3,15 \\
\hline 10,00 & 5,97 & 51,00 & 4,73 & 92,00 & 3,68 & 133,00 & 3,14 \\
\hline 11,00 & 5,95 & 52,00 & 4,66 & 93,00 & 3,67 & 134,00 & 3,13 \\
\hline 12,00 & 5.92 & 53.00 & 4.63 & 94,00 & 3,65 & 135.00 & 3,12 \\
\hline 13,00 & 5.76 & 54.00 & 4.60 & 95,00 & 3,64 & 136.00 & 3,12 \\
\hline 14,00 & 5,82 & 55,00 & 4,60 & 96,00 & 3,62 & 137,00 & 3,13 \\
\hline 15.00 & 5.88 & 56.00 & 4,45 & 97.00 & 3.59 & 138.00 & 3,12 \\
\hline 16.00 & 5.77 & 57.00 & 4,56 & 98.00 & 3.58 & 139.00 & 3.11 \\
\hline 17.00 & 5.77 & 58.00 & 4,52 & 99.00 & 3.57 & 140.00 & 3.10 \\
\hline 18,00 & 5,59 & 59,00 & 4,43 & 100,00 & 3,55 & 141,00 & 3,09 \\
\hline 19,00 & 5,69 & 60,00 & 4,46 & 101,00 & 3,52 & 142,00 & 3,06 \\
\hline 20,00 & 5,62 & 61,00 & 4,46 & 102,00 & 3,51 & 143,00 & 3,07 \\
\hline 21,00 & 5,64 & 62,00 & 4,35 & 103,00 & 3,53 & 144,00 & 3,05 \\
\hline 22,00 & 5,54 & 63,00 & 4,28 & 104,00 & 3,50 & 145,00 & 3,03 \\
\hline 23,00 & 5,54 & 64,00 & 4,28 & 105,00 & 3,49 & 146,00 & 3,04 \\
\hline 24,00 & 5,54 & 65,00 & 4,31 & 106,00 & 3,48 & 147,00 & 3,03 \\
\hline 25,00 & 5,36 & 66,00 & 4,24 & 107,00 & 3,46 & 148,00 & 3,01 \\
\hline 26,00 & 5,42 & 67,00 & 4,29 & 108,00 & 3,45 & 149,00 & 3,02 \\
\hline 27,00 & 5,37 & 68,00 & 4,31 & 109,00 & 3,42 & 150,00 & 3,00 \\
\hline 28,00 & 5,37 & 69,00 & 4,28 & 110,00 & 3,40 & & \\
\hline
\end{tabular}


Tabela 5.32 - Valores de OD em função do tempo, obtidos durante o ensaio para determinação da taxa de consumo de oxigênio na Lagoa de Aeração que não recebeu resíduo da ETA-Fonte. Ensaio realizado no 14 de maio de 2003.

\begin{tabular}{|c|c|c|c|c|c|c|c|}
\hline Tempo & $\mathrm{OD}(\mathrm{mg} / \mathrm{L})$ & Tempo & $\mathrm{OD}(\mathrm{mg} / \mathrm{L})$ & Tempo & $\mathrm{OD}(\mathrm{mg} / \mathrm{L})$ & Tempo & $\mathrm{OD}(\mathrm{mg} / \mathrm{L})$ \\
\hline 0,00 & 7,06 & 29,00 & 4,71 & 70,00 & 3,52 & 111,00 & 3,03 \\
\hline 0,25 & 6,51 & 30,00 & 4,71 & 71,00 & 3,56 & 112,00 & 3,00 \\
\hline 0,50 & 6,47 & 31,00 & 4,61 & 72,00 & 3,49 & 113,00 & 3,01 \\
\hline 0,75 & 6,28 & 32,00 & 4,61 & 73,00 & 3,51 & 114,00 & 2,99 \\
\hline 1,00 & 6,20 & 33,00 & 4,59 & 74,00 & 3,50 & 115,00 & 2,95 \\
\hline 1,50 & 6,12 & 34,00 & 4,48 & 75,00 & 3,46 & 116,00 & 2,96 \\
\hline 2,00 & 6,08 & 35,00 & 4,52 & 76,00 & 3,40 & 117,00 & 2,94 \\
\hline 2,50 & 6,03 & 36,00 & 4,42 & 77,00 & 3,47 & 118,00 & 2,92 \\
\hline 3,00 & 6,00 & 37,00 & 4,40 & 78,00 & 3,44 & 119,00 & 2,94 \\
\hline 3,50 & 5,95 & 38,00 & 4,39 & 79,00 & 3,39 & 120,00 & 2,94 \\
\hline 4,00 & 5,91 & 39,00 & 4,36 & 80,00 & 3,38 & 121,00 & 2,92 \\
\hline 4,50 & 5,85 & 40,00 & 4,36 & 81,00 & 3,37 & 122,00 & 2,93 \\
\hline 5,00 & 5,80 & 41,00 & 4,30 & 82,00 & 3,30 & 123,00 & 2,91 \\
\hline 5,50 & 5,72 & 42,00 & 4,23 & 83,00 & 3,33 & 124,00 & 2,90 \\
\hline 6,00 & 5,74 & 43,00 & 4,23 & 84,00 & 3,20 & 125,00 & 2,88 \\
\hline 6,50 & 5,69 & 44,00 & 4,15 & 85,00 & 3,28 & 126,00 & 2,87 \\
\hline 7,00 & 5,70 & 45,00 & 4,12 & 86,00 & 3,30 & 127,00 & 2,89 \\
\hline 7,50 & 5,61 & 46,00 & 4,09 & 87,00 & 3,21 & 128,00 & 2,90 \\
\hline 8,00 & 5,53 & 47,00 & 4,10 & 88,00 & 3,27 & 129,00 & 2,89 \\
\hline 8,50 & 5,52 & 48,00 & 4,09 & 89,00 & 3,23 & 130,00 & 2,88 \\
\hline 9,00 & 5,50 & 49,00 & 4,03 & 90,00 & 3,25 & 131,00 & 2,87 \\
\hline 9,50 & 5,51 & 50,00 & 3,97 & 91,00 & 3,26 & 132,00 & 2,87 \\
\hline 10,00 & 5,49 & 51,00 & 3,94 & 92,00 & 3,24 & 133,00 & 2,86 \\
\hline 11,00 & 5,45 & 52,00 & 3,92 & 93,00 & 3,19 & 134,00 & 2,86 \\
\hline 12,00 & 5,43 & 53,00 & 3,95 & 94,00 & 3,18 & 135,00 & 2,85 \\
\hline 13,00 & 5,39 & 54,00 & 3,92 & 95,00 & 3,20 & 136,00 & 2,84 \\
\hline 14,00 & 5,40 & 55,00 & 3,89 & 96,00 & 3,18 & 137,00 & 2,83 \\
\hline 15,00 & 5,39 & 56,00 & 3,80 & 97,00 & 3,15 & 138,00 & 2,82 \\
\hline 16,00 & 5,29 & 57,00 & 3,79 & 98,00 & 3,16 & 139,00 & 2,84 \\
\hline 17,00 & 5,34 & 58,00 & 3,84 & 99,00 & 3,13 & 140,00 & 2,81 \\
\hline 18,00 & 5,24 & 59,00 & 3,78 & 100,00 & 3,14 & 141,00 & 2,80 \\
\hline 19,00 & 5,21 & 60,00 & 3,77 & 101,00 & 3,12 & 142,00 & 2,81 \\
\hline 20,00 & 5,17 & 61,00 & 3,73 & 102,00 & 3,12 & 143,00 & 2,80 \\
\hline 21,00 & 5,20 & 62,00 & 3,69 & 103,00 & 3,11 & 144,00 & 2,78 \\
\hline 22,00 & 5,07 & 63,00 & 3,66 & 104,00 & 3,12 & 145,00 & 2,79 \\
\hline 23,00 & 5,06 & 64,00 & 3,67 & 105,00 & 3,14 & 146,00 & 2,78 \\
\hline 24,00 & 4,95 & 65,00 & 3,63 & 106,00 & 3,10 & 147,00 & 2,77 \\
\hline 25,00 & 4,88 & 66,00 & 3,63 & 107,00 & 3,08 & 148,00 & 2,76 \\
\hline 26,00 & 4,90 & 67,00 & 3,64 & 108,00 & 3,07 & 149,00 & 2,76 \\
\hline 27,00 & 4,78 & 68,00 & 3,58 & 109,00 & 3,06 & 150,00 & 2,75 \\
\hline 28,00 & 4,78 & 69,00 & 3,59 & 110,00 & 3,02 & & \\
\hline
\end{tabular}




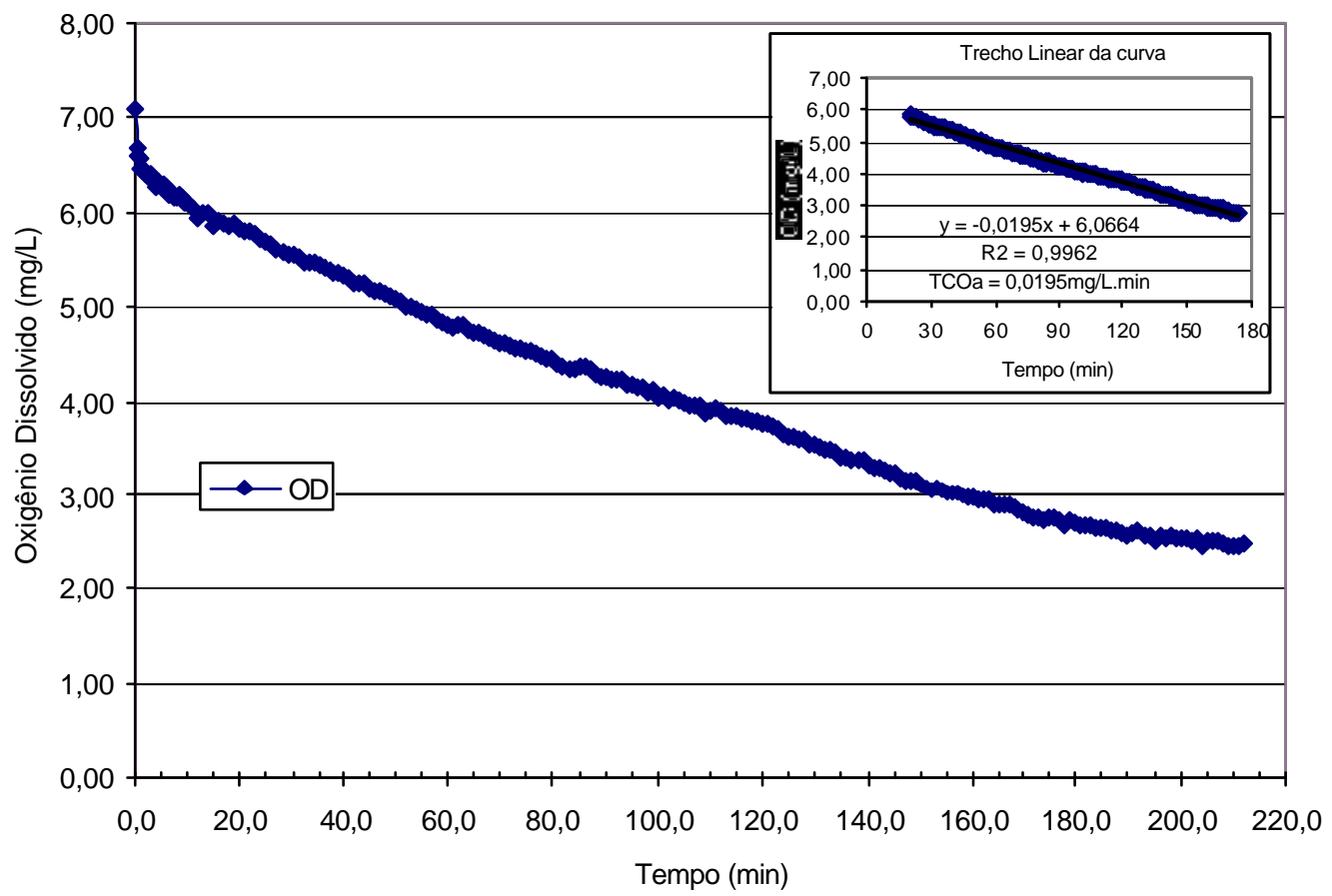

Figura 5.24 - Valores de OD em função do tempo utilizado para determinação da TCO na lagoa de aeração que recebeu resíduo de ETA-Fonte. No detalhe observe o trecho linear da curva. Ensaio realizado no dia 2 de maio de 2003.

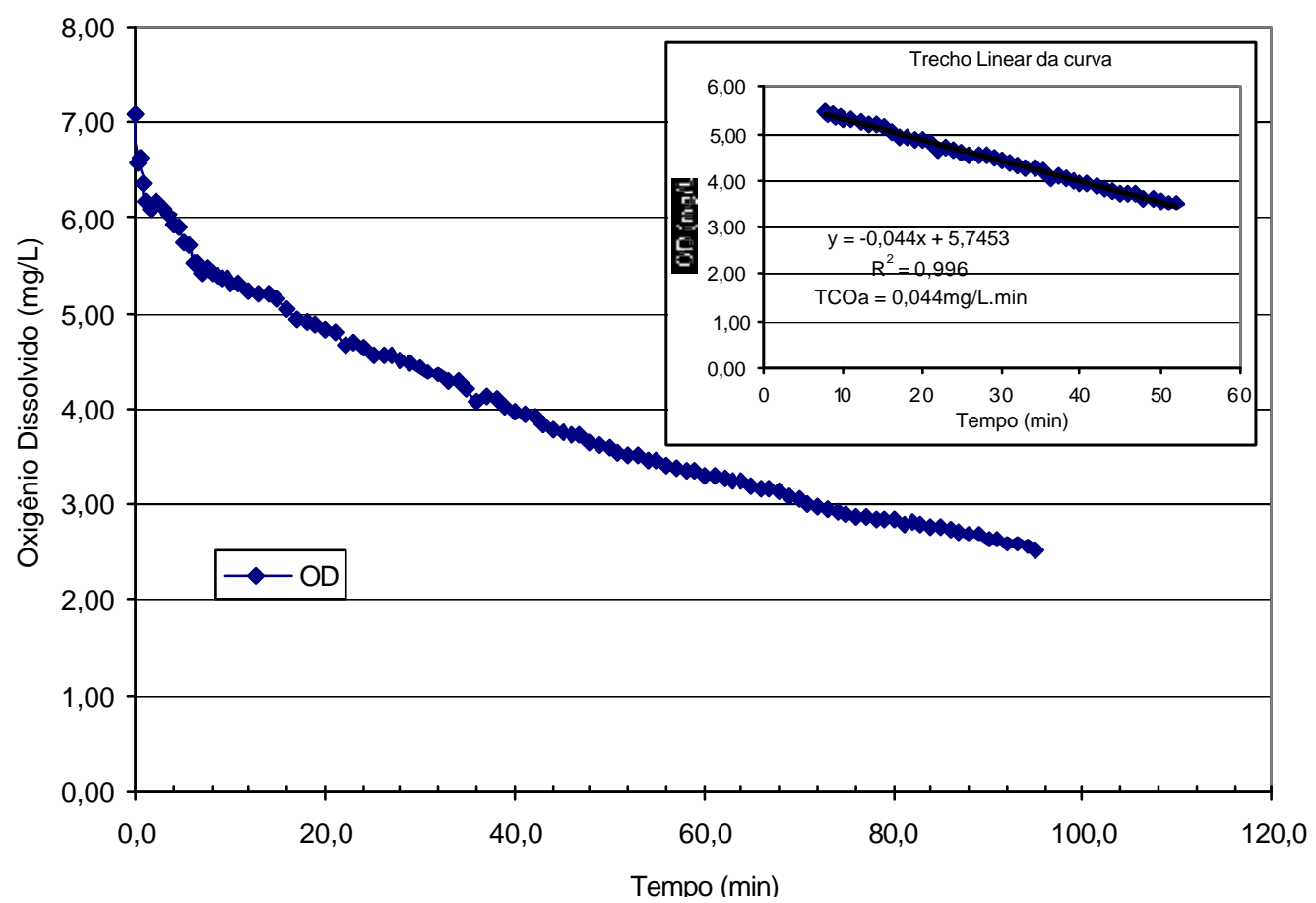

Figura 5.25 - Valores de OD em função do tempo utilizado para determinação da TCO na lagoa de aeração que não recebeu resíduo de ETAFonte. No detalhe observe o trecho linear da curva. Ensaio realizado no dia 2 de maio de 2003. 


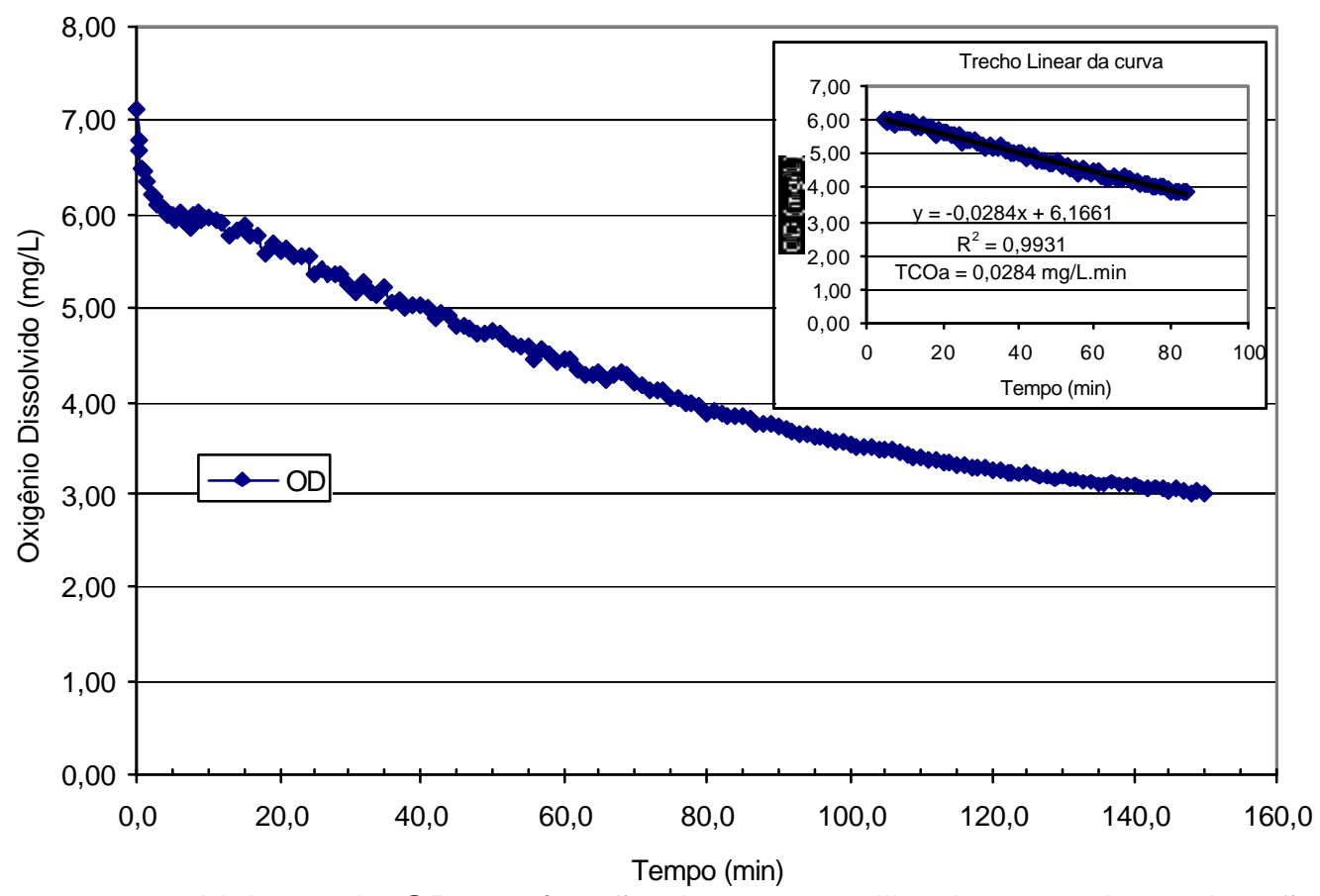

Figura 5.26 - Valores de OD em função do tempo utilizado para determinação da TCO na lagoa de aeração que recebeu resíduo de ETA-Fonte. No detalhe observe o trecho linear da curva. Ensaio realizado no dia 14 de maio de 2003.

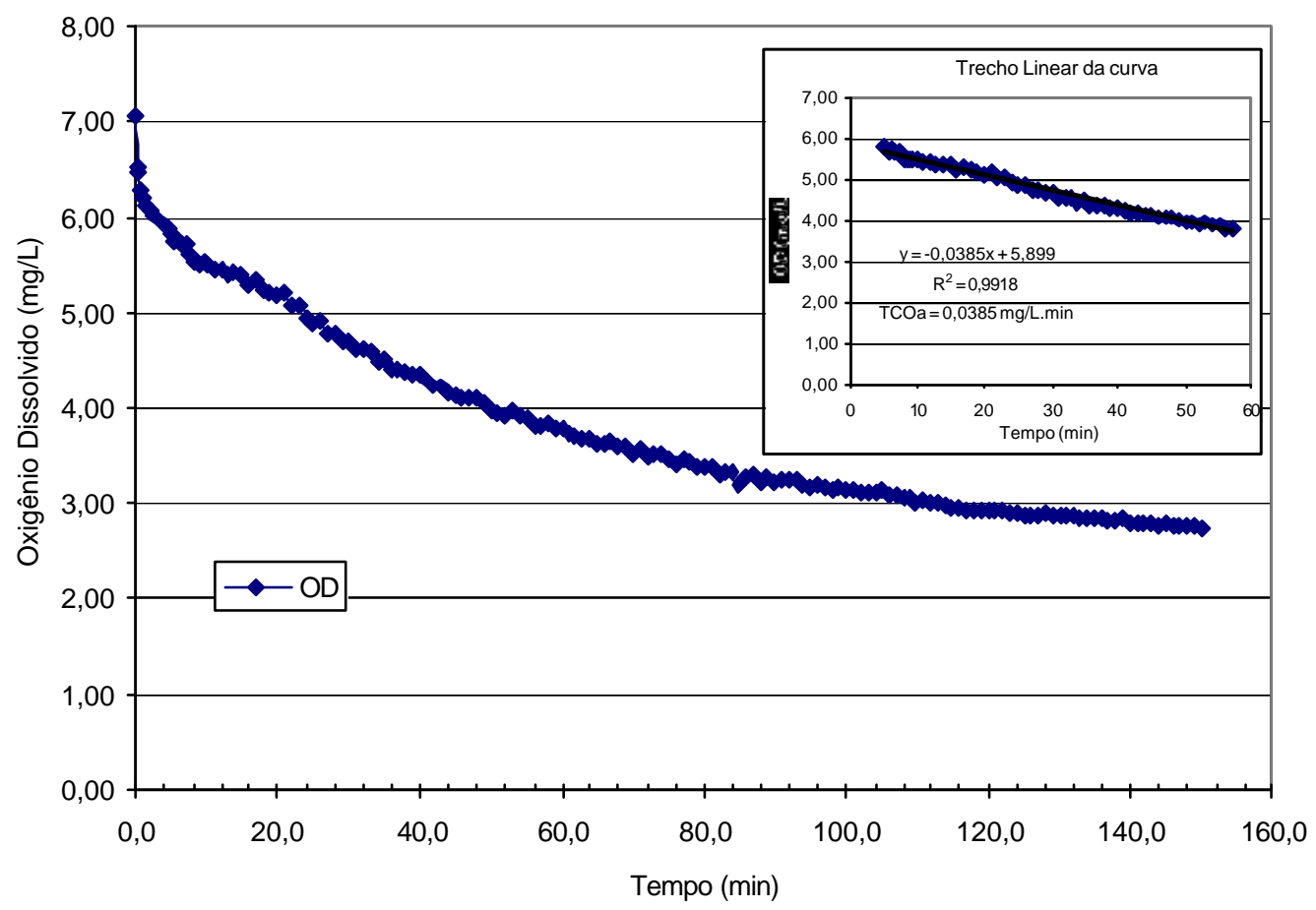

Figura 5.27 - Valores de OD em função do tempo utilizado para determinação da TCO na lagoa de aeração que não recebeu resíduo de ETAFonte. No detalhe observe o trecho linear da curva. Ensaio realizado no dia 14 de maio de 2003. 


\subsection{Ensaio de Sedimentabilidade}

Devido a pouca concentração de sólidos no licor misto das lagoas de aeração foi necessário a utilização do Cone Imhoff para poder avaliar a sedimentabilidade do lodo.

Os resultados do volume de sólidos sedimentáveis em função do tempo estão contidos na tabela 5.33. Na figura 5.28, pode ser observado que o volume de sólidos sedimentáveis atingiu seu pico após 7 minutos de sedimentação no licor misto da lagoa de aeração 1 e após 10 minutos no licor da lagoa 2. Após este tempo o material começou a sofrer adensamento, atingindo, no final do ensaio, 15,5 $\mathrm{mL}$ e 13,0 mL, respectivamente. Portanto, o volume de sólidos sedimentáveis, decorridos 60 minutos, foi maior para o material que recebeu resíduo da ETAFonte, representando 19,2\% mais lodo que a lagoa 2. Esta porcentagem é decorrente do incremento do resíduo da ETA-Fonte ao sistema, o que já era esperado uma vez que este resíduo apresenta uma grande quantidade de sólidos sedimentáveis. Estes sólidos não influenciaram no tratamento, o que acontecerá será um aumento no volume de lodo nas lagoas de sedimentação.

Tabela 5.33 - Concentração de sólidos sedimentáveis em função do tempo. Ensaio realizado em Cone Imhoff no dia 14 de maio de 2003.

\begin{tabular}{c|c|c}
\hline \multirow{2}{*}{$\begin{array}{c}\text { Tempo } \\
\text { (min.) }\end{array}$} & $\begin{array}{c}\mid c \\
\text { Sicor misto da Lagoa de Aeração que } \\
\text { recebeu resíduo da ETA-Fonte. }\end{array}$ & $\begin{array}{c}\text { Licor misto da Lagoa de Aeração que } \\
\text { recebeu resíduo da ETA-Fonte. }\end{array}$ \\
\cline { 2 - 3 } & 2,0 & 1,5 \\
\hline 1 & 9,0 & 5,5 \\
\hline 2 & 14,0 & 10,0 \\
\hline 3 & 17,0 & 12,0 \\
\hline 4 & 19,0 & 13,0 \\
\hline 5 & 20,0 & 13,5 \\
\hline 6 & 20,5 & 14,5 \\
\hline 7 & 20,5 & 15,5 \\
\hline 8 & 20,5 & 15,5 \\
\hline 9 & 20,5 & 16,0 \\
\hline 10 & 20,5 & 16,0 \\
\hline 15 & 20,0 & 15,5 \\
\hline 20 & 19,5 & 15,5 \\
\hline 25 & 18,8 & 15,0 \\
\hline 30 & 17,0 & 14,0 \\
\hline 45 & 15,5 & 13,0 \\
\hline 60 & &
\end{tabular}


CONCENTRAÇÃO DE SÓLIDOS SEDIMENTÁVEIS EM FUNÇÃO DO TEMPO NOS LICORES MISTOS DAS LAGOAS DE AERAÇÃO

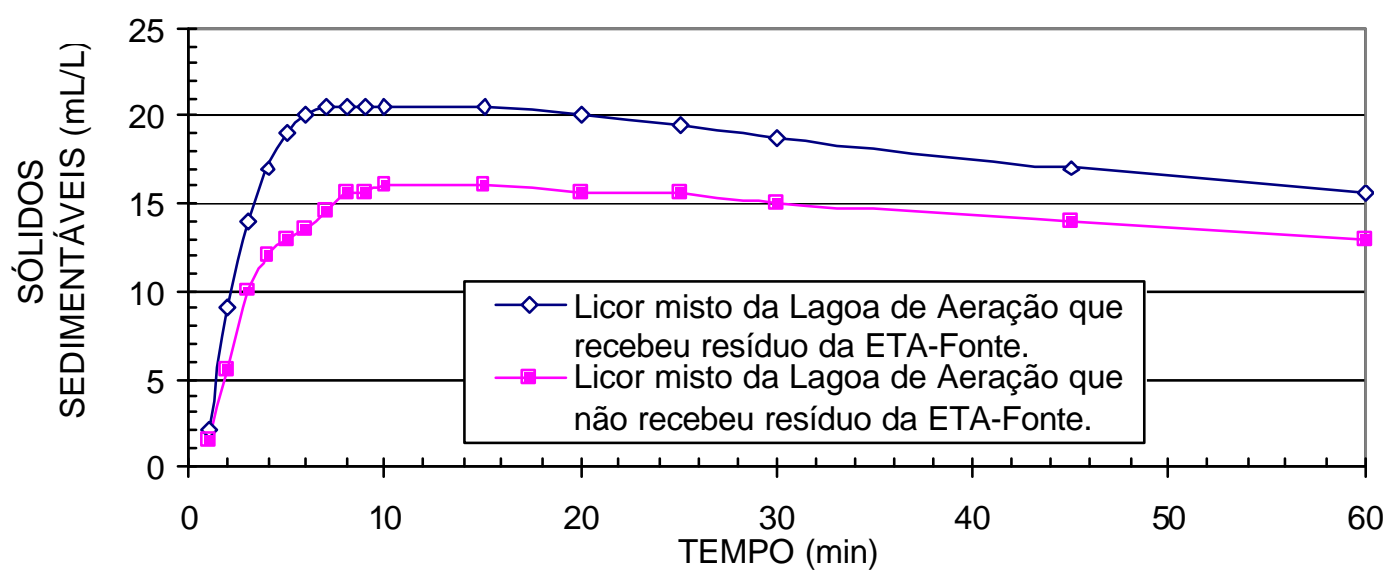

Figura 5.28 - Ensaio de Sedimentabilidade dos licores mistos das lagoas de aeração realizado em Cone Imhoff em função do tempo. Ensaio realizado no dia 14 de maio de 2003.

\subsection{Exame Microscópico}

Após 90 dias de operação, antes de interromper o tratamento, foi realizado novo exame microscópico nos licores mistos presentes nas lagoas de aeração.

O licor da lagoa de aeração 1, que recebeu resíduo da ETAFonte, aparentemente, não apresentou interferências negativas na sua microfauna. $O$ aspecto deste material ao microscópio foi de flocos bem formados com presença de ciliados pedunculados e, nos espaços entre flocos, de ciliados livre-natantes e rotíferos, existindo também a presença de nematóides que são indicativos de boa depuração. Foram encontrados anelídeos do gênero Aelosoma que quando em predominância indicam excesso de oxigênio dissolvido. Uma característica deste material foi a ausência de bactérias filamentosas e bactérias do gênero Spirillum que estavam presentes no licor misto da lagoa de aeração 2 que não recebeu resíduo da ETA-Fonte.

A quantidade de microrganismos presentes no licor misto da lagoa 1 que recebeu resíduo da ETA-Fonte foi superior que os presentes no licor misto da lagoa de aeração 2 que não recebeu este resíduo.

Foram encontradas algumas algas verdes, diatomáceas e hifas de fungos no licor misto da lagoa que não recebeu resíduo da ETA-Fonte. Portanto, o resíduo da ETA-Fonte impediu o aparecimento destes microrganismos. 
As fotografias das figuras 5.29 a 5.32 ilustram alguns dos microrganismos encontrados na microfauna do licor misto da lagoa de aeração que recebeu resíduo da ETA-Fonte.

As fotografias das figuras 5.33 a 5.35 ilustram alguns dos microrganismos encontrados na microfauna do licor misto da lagoa de aeração que não recebeu resíduo da ETA-Fonte.

(A)

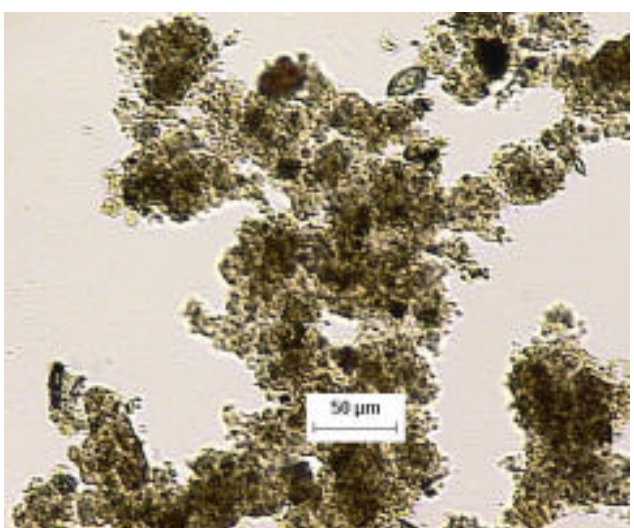

Figura 5.29 - Aspidisca spp no licor da lagoa de aeração que recebeu resíduo de ETA. É um ciliado livre rastejante, predador de flocos. Indicativo de Nitrificação. (B) Presença de rotífero do gênero Philodina no licor da lagoa de aeração que recebeu resíduo de ETA.
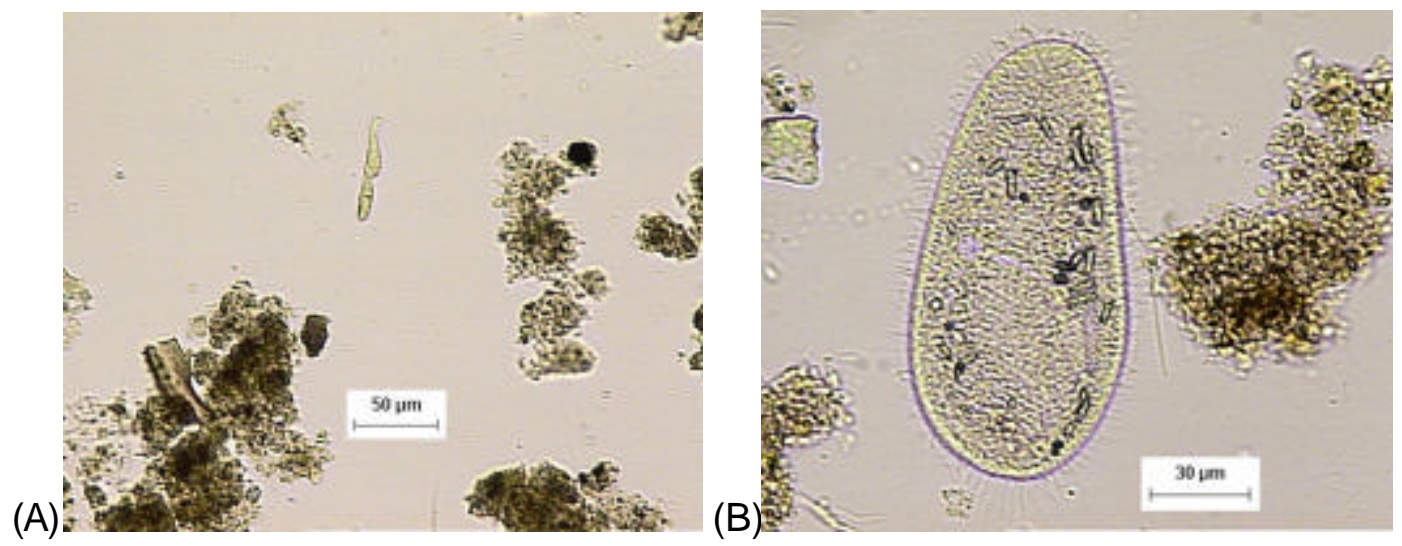

Figura 5.30 - (A) Presença de ciliado livre-natante do gênero Trachelophyllum no licor da lagoa de aeração que recebeu resíduo de ETA. Indicativo de $\theta_{c}$ alto. (B) Presença de ciliado livre-natante do gênero Paramecium no licor da lagoa de aeração que recebeu resíduo de ETA. 

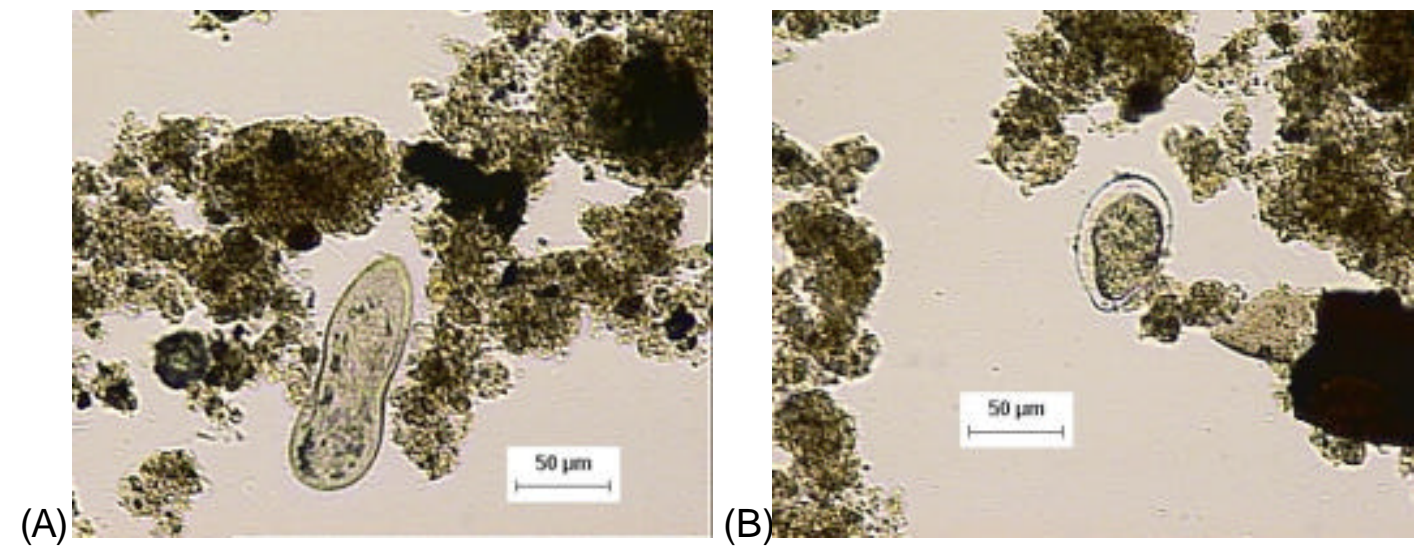

Figura 5.31 - (A) Presença de ciliado livre-natante do gênero Paramecium no licor da lagoa de aeração que recebeu resíduo de ETA. (B) Presença de cisto de ovo ou cisto de rotífero no licor da lagoa de aeração que recebeu resíduo de ETA.

(A)

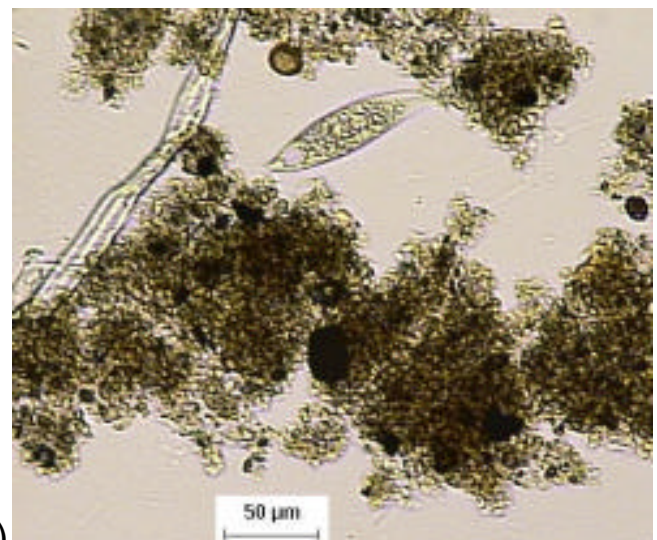

(B)

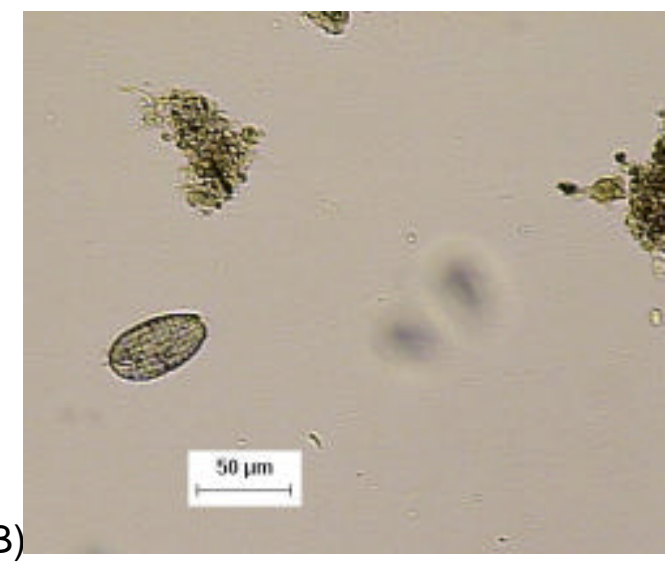

Figura 5.32 - (A) Presença de ciliado livre-natante semelhante ao gênero Litonotus no licor da lagoa de aeração que recebeu resíduo de ETA. (B) Presença de ciliado semelhante a Coleps hirtus no licor da lagoa de aeração que recebeu resíduo.
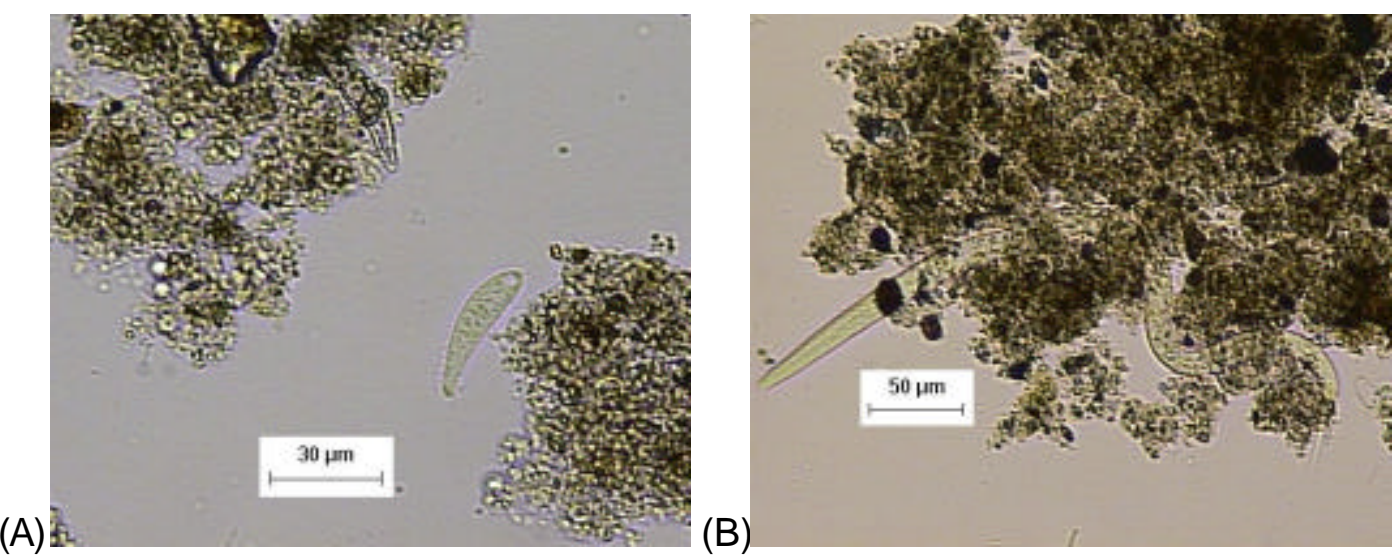

Figura 5.33 - (A) Presença de ciliado livre no licor da lagoa de aeração que não recebeu resíduo de ETA. (B)Presença de nematóide no licor da lagoa de aeração que não recebeu resíduo de ETA 

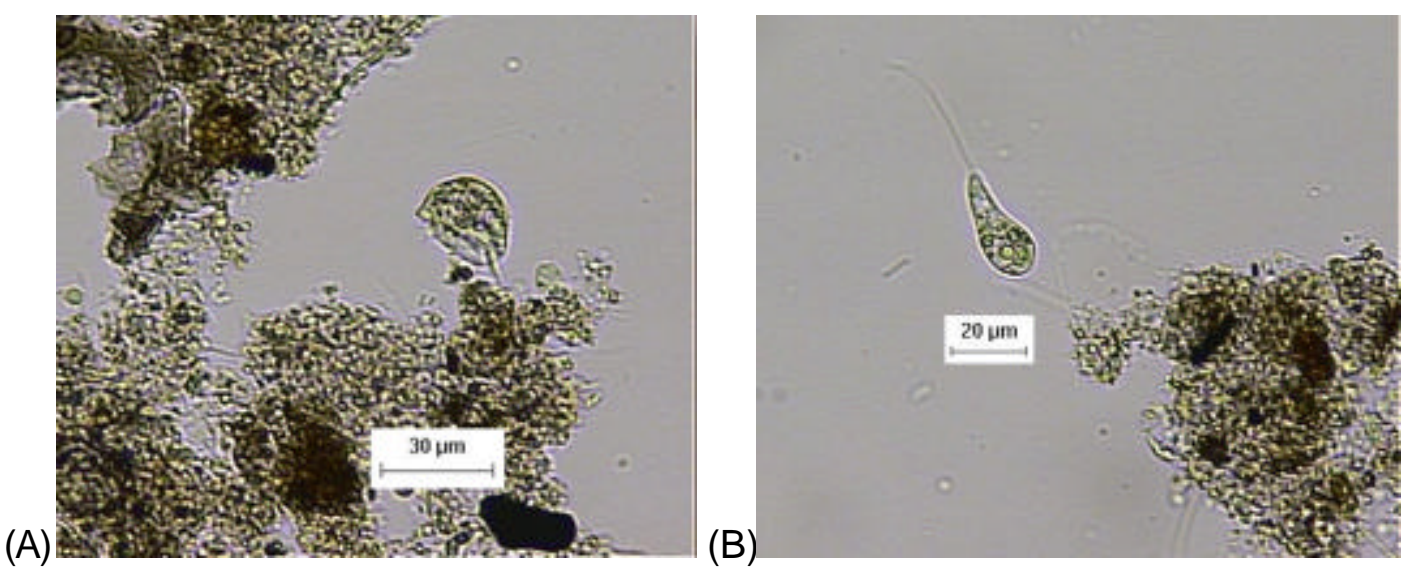

Figura 5.34 - (A) Presença de ciliado semelhante ao gênero Aspidisca no licor da lagoa de aeração que não recebeu resíduo de ETA. (B) Organismo semelhante a cloroflagelado presente no licor da lagoa de aeração que não recebeu resíduo de ETA

(A)
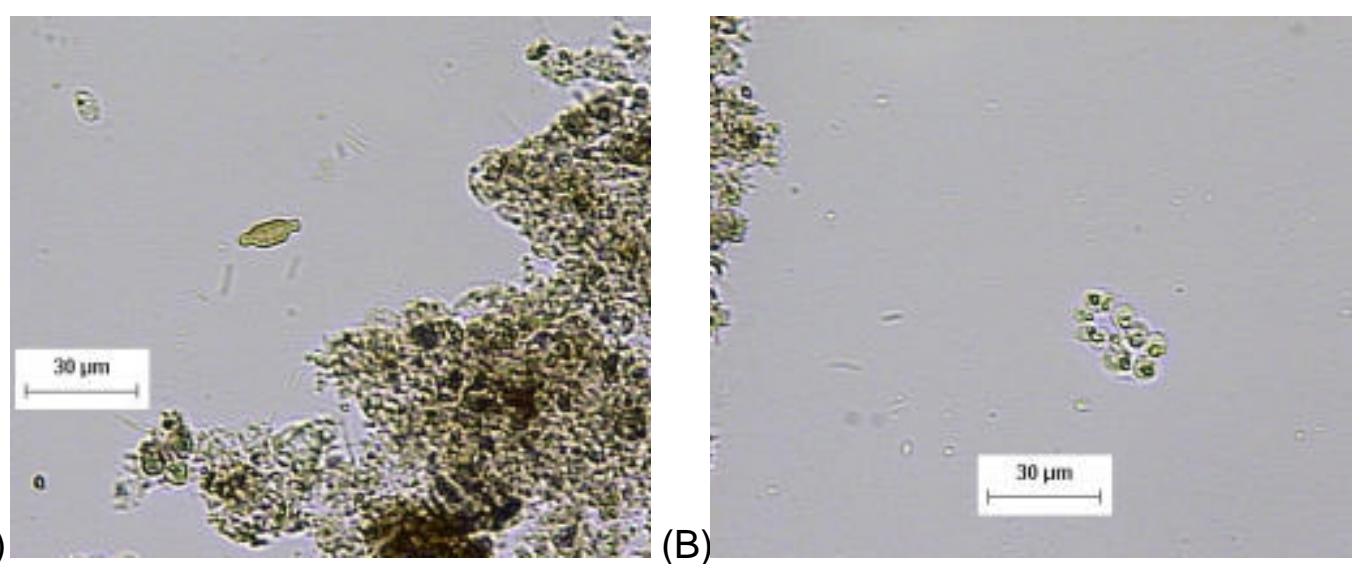

Figura 5.35 - (A) Organismo semelhante a diatomácea presente no licor da lagoa de aeração que não recebeu resíduo de ETA. (B) - Organismo semelhante a alga verde presente no licor misto da lagoa de aeração que não recebeu resíduo.

\subsection{Caracterização do Lodo das Lagoas de Sedimentação}

Visando a caracterização e o conhecimento do volume de lodo gerado nas ETEs-piloto foram realizadas caracterizações dos lodos obtidos no final da operação dos sistemas. Após, retirada de todo sobrenadante, com auxílio de uma bomba de sucção, os lodos foram retirados e caracterizados (ver tabela 5.34).

A DQO total encontrada no lodo foi de $37,14 \mathrm{~g}$ na lagoa 1 e $37,7 \mathrm{~g}$ na lagoa 2 , sendo praticamente iguais. 
Devido a forma com que foram removidos os sobrenadantes das lagoas de sedimentação 1 e 2, os ST do lodo da lagoa 1 apresentou-se em menor concentração, mas em maior volume. A massa total de sólidos foi de 49,47 g e 43,05 g, respectivamente, ou seja a lagoa de sedimentação 1, proveniente da ETEpiloto que recebeu resíduo da ETA-Fonte, apresentou uma maior quantidade de ST. Estes foram representados por $49,81 \%(24,64 \mathrm{~g})$ de SF e $50,19 \%(24,83 \mathrm{~g})$ de SV ao contrário do lodo da lagoa 2, proveniente da ETE-piloto que não recebeu resíduo da ETA-Fonte, onde $41,17 \%$ (17,73 g) foram na forma de SF e 58,83\% $(25,33 \mathrm{~g})$ na forma de SV.

Observa-se, na tabela 5.34, que em relação aos metais pesquisados o $\mathrm{Fe} e$ o Mn foram os que apresentaram maiores divergências. A concentração do Fe no lodo da lagoa 1 foi de $4504 \mathrm{mg}$ ( 2815,0 mg/L x 1,6 L lodo), contra $1407 \mathrm{mg}$ (1153,0 $\mathrm{mg} / \mathrm{L} \times 1,22 \mathrm{~L}$ lodo), representando $220,11 \%$ a mais deste metal. Com relação ao Mn este aumento foi de $189,51 \%$.

Estes valores são perfeitamente explicados uma vez que na ETA-Fonte é utilizado como coagulante o cloreto férrico $\left(\mathrm{FeCl}_{3}\right)$, trabalhando com $\mathrm{pH}$ de floculação em torno de 8,5, o que favorece a precipitação do Fe e do Mn, presentes na água bruta, na forma de hidróxidos. Portanto, o resíduo da ETA-Fonte adicionado a lagoa de aeração 1, favoreceu o seu aumento da concentração destes metais no lodo da lagoa de sedimentação 1.

\subsection{Resistência Específica do Lodo}

Os ensaios para determinação da resistência específica foram realizados nos lodos das lagoas de sedimentação das ETEs-piloto que receberam ou não resíduo da ETA-Fonte apresentando, respectivamente, $\mathrm{SST}_{\mathrm{i}}=28,2 \mathrm{~g} / \mathrm{L}$ e 32,0 e, os resultados dos volumes filtrados em função do tempo encontram-se na tabela 5.35.

Nas Figuras 5.36 e 5.37 foram plotados os valores da relação t/v em função do volume filtrado obtendo o valor de $\mathbf{b}$, coeficiente utilizado no cálculo da resistência específica, através da regressão linear da reta de melhor ajuste. 
Tabela 5.34 - Caracterização dos lodos obtidos nas lagoas de sedimentação após término da operação das ETEs-piloto.

\begin{tabular}{|c|c|c|}
\hline PARÂMETROS & LAGOA 1 & LAGOA 2 \\
\hline DQO (g/L) & 23,21 & 30,90 \\
\hline $\mathrm{pH}$ & 7,1 & 7,0 \\
\hline Sólidos Totais (g/L) & 30,92 & 35,29 \\
\hline Sólidos Fixos (g/L) & 15,40 & 14,53 \\
\hline Sólidos Voláteis (g/L) & 15,52 & 20,76 \\
\hline Sólidos Suspensos Totais (g/L) & 28,20 & 32,00 \\
\hline Sólidos Suspensos Fixos (g/L) & 13,00 & 11,60 \\
\hline Sólidos Suspensos Voláteis (g/L) & 15,20 & 20,40 \\
\hline Sólidos Dissolvidos Totais (g/L) & 2,72 & 3,29 \\
\hline Sólidos Dissolvidos Fixos (g/L) & 2,40 & 2,93 \\
\hline Sólidos Dissolvidos Voláteis (g/L) & 0,32 & 0,36 \\
\hline Resistência Específica $\left(\times 10^{13} \mathrm{~m} / \mathrm{kg}\right)$ & 1,42 & 4,40 \\
\hline Volume total de Lodo (L/15L) & 1,60 & 1,22 \\
\hline Massa total de sólidos (g) & 49,47 & 43,5 \\
\hline \multicolumn{3}{|l|}{ Ensaio de Centrifugação: } \\
\hline - Melhor dosagem de polieletrólito (g polieletrólito / kg SST) & 2,0 & 3,5 \\
\hline - $\mathrm{SST}_{\mathrm{r}}$ no centrifugado após $30 \mathrm{~min}(\mathrm{~g} / \mathrm{L})$ & 128,2 & 128,0 \\
\hline Manganês (mg Mn / kg SST) & 924,1 & 368,9 \\
\hline Ferro (mg Fe / kg SST) & 99822,7 & 36040,6 \\
\hline Níquel (mg Ni / kg SST) & 221,3 & 442,2 \\
\hline Zinco (mg Zn / kg SST) & 1236,9 & 1786,4 \\
\hline Chumbo (mg Pb / kg SST) & 128,1 & 142,9 \\
\hline Cádmio (mg Cd / kg SST) & 5,1 & 5,3 \\
\hline Cobre (mg Cu / kg SST) & 292,2 & 342,2 \\
\hline Cromo (mg Cr / kg SST) & 1168,8 & 2394,7 \\
\hline Cobalto (mg Co / kg SST) & 21,2 & 19,7 \\
\hline
\end{tabular}


Os valores de resistência específica estão contidos na tabela 5.36, constatando que o lodo da lagoa de sedimentação 1 apresentou $1,42 \times 10^{13} \mathrm{~m} / \mathrm{kg}$, sendo $67,73 \%$ menor que a resistência específica do lodo da lagoa de sedimentação 2, que foi de $4,40 \times 10^{13} \mathrm{~m} / \mathrm{kg}$. Provavelmente, isto se deve a presença do coagulante, cloreto férrico, presente no lodo do resíduo da ETA-Fonte adicionado a ETE-piloto, funcionando como um condicionante, favorecendo a filtação em tempos menores, resultando em uma resistência específica menor.

Tabela 5.35 - Tempo de filtração dos lodos obtidos nas lagoas de sedimentação das ETEs-piloto, em função do volume, utilizado no teste da resistência específica.

\begin{tabular}{ccc}
\hline \multirow{2}{*}{$\begin{array}{c}\text { Volume } \\
\text { (mL) }\end{array}$} & Lodo da lagoa de sedimentação $\mathbf{1}$ & Lodo da lagoa de sedimentação 2 \\
\cline { 2 - 4 } $\mathbf{3}$ & 4,42 & 14,77 \\
$\mathbf{5}$ & 18,2 & 58,02 \\
$\mathbf{7}$ & 39,25 & 126,43 \\
$\mathbf{9}$ & 70,55 & 243,12 \\
$\mathbf{1 1}$ & 109,93 & 380,77 \\
$\mathbf{1 3}$ & 165,58 & 558,27 \\
$\mathbf{1 5}$ & 230,55 & 803,55 \\
$\mathbf{1 7}$ & 318,71 & 1085,22 \\
$\mathbf{1 9}$ & 481,93 & 1637,87 \\
$\mathbf{2 1}$ & 939,02 & 5534,02 \\
\hline Obs.: & Lodo da lagoa de Sedimentação 1- proveniente da ETE-piloto que recebeu resíduo da ETA-Fonte. \\
& Lodo da lagoa de sedimentação 2 - proveniente da ETE-piloto que não recebeu resíduo da ETA-Fonte.
\end{tabular}

Tabela 5.36 - Valores de resistência específica nos lodos das lagoas de sedimentação.

\begin{tabular}{cc}
\hline Lodo da lagoa de sedimentação 1 & Lodo da lagoa de sedimentação 2 \\
\hline $1,42 \times 10^{13} \mathrm{~m} / \mathrm{kg}$ & $4,40 \times 10^{13} \mathrm{~m} / \mathrm{kg}$ \\
\hline Obs.: & $\begin{array}{l}\text { Lodo da lagoa de Sedimentação 1 - proveniente da ETE-piloto que recebeu resíduo da ETA-Fonte. } \\
\text { Lodo da lagoa de sedimentação 2 - proveniente da ETE-piloto que não recebeu resíduo da ETA-Fonte. }\end{array}$
\end{tabular}




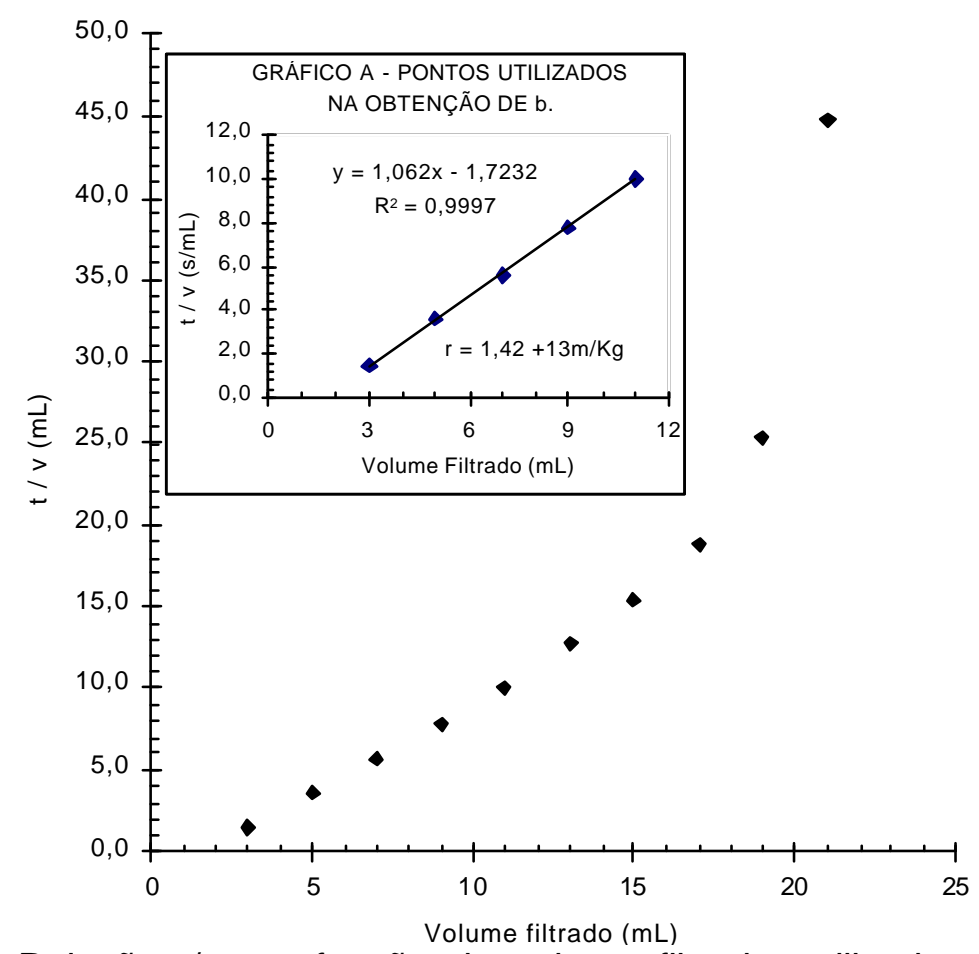

Figura 5.36- Relação t/v em função do volume filtrado, utilizado no cálculo da resistência específica do lodo da lagoa de sedimentação proveniente da ETE-piloto que recebeu resíduo da ETA-Fonte. $S S T_{i}=28,20 \mathrm{~g} / \mathrm{L}$.

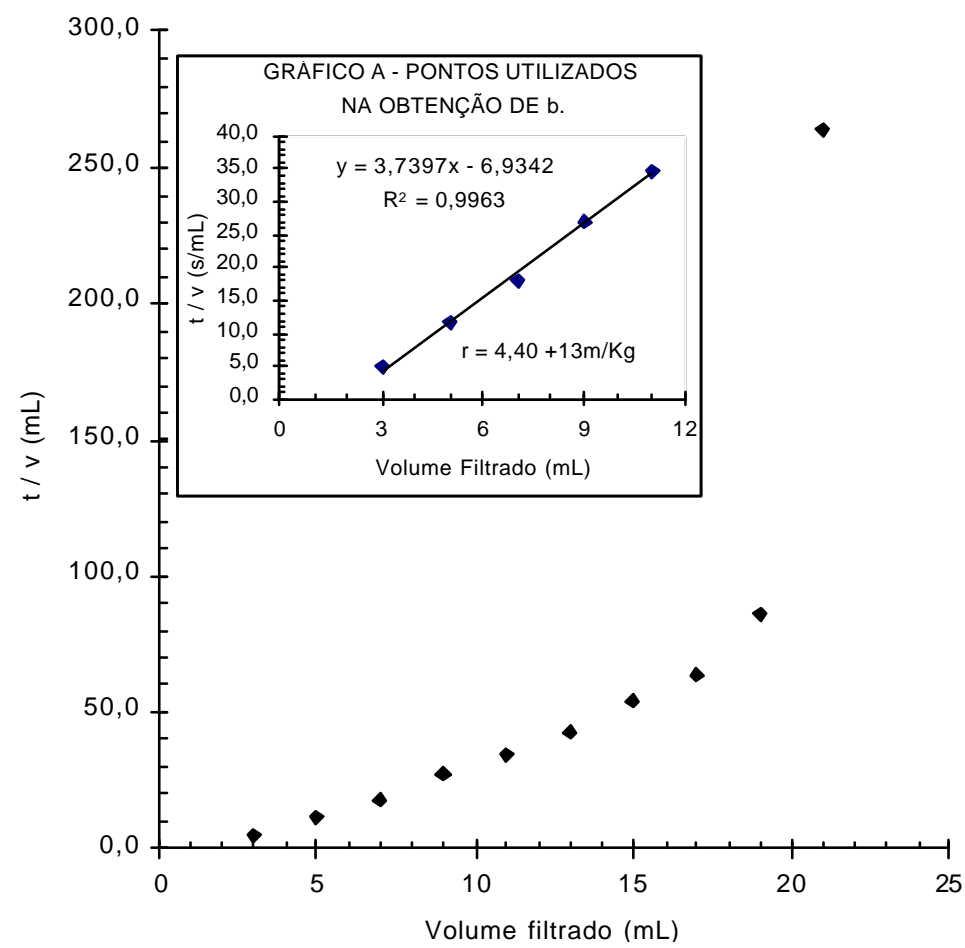

Figura 5.37 - Relação t/v em função do volume filtrado, utilizado no cálculo da resistência específica do lodo da lagoa de sedimentação proveniente da ETE-piloto que recebeu resíduo da ETA-Fonte. $\mathrm{SST}_{\mathrm{i}}=32,0 \mathrm{~g} / \mathrm{L}$. 


\subsubsection{Desidratação do Lodo por Centrifugação}

Os lodos das lagoas de sedimentação das ETEs-piloto que receberam ou não resíduo da ETAFonte apresentando, respectivamente, $S_{S T}=28,2 \mathrm{~g} / \mathrm{L}$ e 32,0, foram distribuídos em tubos graduados de fundos cônicos até o volume de 10,0 mL. Posteriormente, foram adicionados diferentes concentrações de polieletrólito catiônico em função da concentração de $S_{S T} T_{i}$ e, submetidos a centrifugação com aproximadamente $3.000 \mathrm{rpm}$ (1000 g).

Em função do volume inicial da amostra de lodo, do volume final de lodo resultante e do teor de SST inicial na amostra, foi utilizada a seguinte equação para determinação do teor de SST na amostra de lodo após centrifugação:

$$
S S T_{\text {final }}=S S T_{\text {inicial }} \frac{V_{t}}{V_{c}}
$$

em que:

$\mathrm{SST}_{\mathrm{r}}=$ Sólidos suspensos totais após centrifugação $(\mathrm{g} / \mathrm{L})$

$\mathrm{SST}_{\mathrm{i}}=$ Sólidos suspensos totais inicial na amostra $(\mathrm{g} / \mathrm{L})$

$\mathrm{V}_{\mathrm{t}}=$ Volume inicial no tubo da centrifuga (usado $10 \mathrm{~mL}$ )

$\mathrm{V}_{\mathrm{c}}=$ Volume de sólidos lido no tubo após centrifugação $(\mathrm{mL})$

Os resultados obtidos nos ensaios de centrifugação estão contidos nas tabelas 5.37 a 5.40 , para os lodos obtidos das lagoas que receberam ou não o resíduo da ETA-Fonte. Nos gráficos das figuras 5.38 e 5.39, estão plotados os valores de $\mathrm{SST}_{\mathrm{r}}$ em função das concentrações de polieletrólito catiônico e do tempo de centrifugação, constantes nas tabelas 5.38 e 5.40 .

Os valores de SST $_{\mathrm{r}}$ no centrifugado após 30 minutos de centrifugação foram de 128,2 g/L e 128,0 g/L, para os lodos da lagoa 1 e 2 , respectivamente, sendo que para atingir esta concentração foram necessários 2,0 g de polieletrólito / kg de SST para o lodo da lagoa 1 que recebeu resíduo da ETA-Fonte e, de 3,5 g de polieletrólito / kg de SST para o lodo da lagoa 2 que não recebeu resíduo da ETA, evidenciando novamente que o resíduo da ETA favoreceu a desidratação de forma mecânica, ou seja, a centrifugação. 
Tabela 5.37 - Volume de sólidos no fundo do tubo em função do tempo de centrifugação para as diferentes concentrações de polieletrólito empregada no ensaio utilizando lodo da lagoa de sedimentação que recebeu resíduo de ETA.

\begin{tabular}{cccccccccc}
\hline $\begin{array}{c}\text { Concentração de } \\
\text { polieletrólito }\end{array}$ & \multicolumn{10}{c}{ Tempo (min) } \\
\cline { 2 - 9 } (g poli/kg SST) & $\mathbf{2 , 5}$ & $\mathbf{5 , 0}$ & $\mathbf{7 , 5}$ & $\mathbf{1 0 , 0}$ & $\mathbf{1 5 , 0}$ & $\mathbf{2 0 , 0}$ & $\mathbf{3 0 , 0}$ & $\mathbf{4 5 , 0}$ & $\mathbf{6 0 , 0}$ \\
\hline 0,0 & 3,50 & 3,10 & 3,00 & 2,90 & 2,70 & 2,60 & 2,55 & 2,50 & 2,5 \\
1,0 & 3,20 & 2,90 & 2,70 & 2,70 & 2,50 & 2,40 & 2,40 & 2,30 & 2,30 \\
1,5 & 3,10 & 2,80 & 2,70 & 2,60 & 2,50 & 2,50 & 2,40 & 2,30 & 2,20 \\
2,0 & 2,80 & 2,50 & 2,40 & 2,40 & 2,30 & 2,20 & 2,20 & 2,15 & 2,15 \\
2,5 & 2,90 & 2,60 & 2,50 & 2,50 & 2,40 & 2,40 & 2,30 & 2,25 & 2,20 \\
3,0 & 2,90 & 2,60 & 2,50 & 2,50 & 2,50 & 2,40 & 2,35 & 2,30 & 2,30 \\
3,5 & 3,00 & 2,70 & 2,70 & 2,50 & 2,50 & 2,50 & 2,50 & 2,40 & 2,30 \\
4,0 & 2,90 & 2,80 & 2,50 & 2,40 & 2,40 & 2,30 & 2,30 & 2,20 & 2,20 \\
\hline
\end{tabular}

Tabela 5.38 - Teor de SST r nos lodo em função do tempo de centrifugação para as diferentes concentrações de polieletrólito empregada no ensaio utilizando lodo da lagoa de sedimentação que recebeu resíduo de ETA.

\begin{tabular}{|c|c|c|c|c|c|c|c|c|c|}
\hline \multirow{2}{*}{$\begin{array}{l}\text { Concentração de } \\
\text { polieletrólito } \\
\text { (g poli/kg SST) }\end{array}$} & \multicolumn{9}{|c|}{ Tempo (min) } \\
\hline & 2,5 & 5,0 & 7,5 & 10,0 & 15,0 & 20,0 & 30,0 & 45,0 & 60,0 \\
\hline 0,0 & 80,6 & 91,0 & 94,0 & 97,2 & 104,4 & 108,5 & 110,6 & 112,8 & 112,8 \\
\hline 1,0 & 88,1 & 97,2 & 104,4 & 104,4 & 112,8 & 117,5 & 117,5 & 122,6 & 122,6 \\
\hline 1,5 & 91,0 & 100,7 & 104,4 & 108,5 & 112,8 & 112,8 & 117,5 & 122,6 & 128,2 \\
\hline 2,0 & 100,7 & 112,8 & 117,5 & 117,5 & 122,6 & 128,2 & 128,2 & 131,2 & 131,2 \\
\hline 2,5 & 97,2 & 108,5 & 112,8 & 112,8 & 117,5 & 117,5 & 122,6 & 125,3 & 128,2 \\
\hline 3,0 & 97,2 & 108,5 & 112,8 & 112,8 & 112,8 & 117,5 & 120,0 & 122,6 & 122,6 \\
\hline 3,5 & 94,0 & 104,4 & 104,4 & 112,8 & 112,8 & 112,8 & 112,8 & 117,5 & 122,6 \\
\hline 4,0 & 97,2 & 100,7 & 112,8 & 117,5 & 117,5 & 122,6 & 122,6 & 128,2 & 128,2 \\
\hline
\end{tabular}


Tabela 5.39 - Volume de sólidos no fundo do tubo em função do tempo de centrifugação para as diferentes concentrações de polieletrólito empregada no ensaio utilizando lodo da lagoa de sedimentação que não recebeu resíduo de ETA.

\begin{tabular}{cccccccccc}
\hline $\begin{array}{c}\text { Concentração de } \\
\text { polieletrólito }\end{array}$ & \multicolumn{10}{c}{ Tempo (min) } \\
\cline { 2 - 10 } (g poli/kg SST) & $\mathbf{2 , 5}$ & $\mathbf{5 , 0}$ & $\mathbf{7 , 5}$ & $\mathbf{1 0 , 0}$ & $\mathbf{1 5 , 0}$ & $\mathbf{2 0 , 0}$ & $\mathbf{3 0 , 0}$ & $\mathbf{4 5 , 0}$ & $\mathbf{6 0 , 0}$ \\
\hline 0,0 & 3,70 & 3,50 & 3,45 & 3,40 & 3,30 & 3,25 & 3,15 & 3,10 & 3,00 \\
1,0 & 3,80 & 3,50 & 3,40 & 3,30 & 3,25 & 3,20 & 3,10 & 3,05 & 3,00 \\
1,5 & 3,40 & 3,30 & 3,10 & 3,00 & 3,00 & 2,90 & 2,75 & 2,70 & 2,70 \\
2,0 & 3,30 & 3,00 & 2,95 & 2,90 & 2,90 & 2,80 & 2,70 & 2,65 & 2,60 \\
2,5 & 3,10 & 3,00 & 2,95 & 2,90 & 2,85 & 2,80 & 2,70 & 2,65 & 2,60 \\
3,0 & 3,10 & 3,00 & 2,90 & 2,80 & 2,80 & 2,80 & 2,70 & 2,65 & 2,60 \\
3,5 & 2,90 & 2,90 & 2,80 & 2,80 & 2,70 & 2,70 & 2,50 & 2,50 & 2,50 \\
4,0 & 3,10 & 3,00 & 2,90 & 2,90 & 2,90 & 2,80 & 2,70 & 2,70 & 2,70 \\
\hline
\end{tabular}

Tabela 5.40 - Teor de SST, nos lodo em função do tempo de centrifugação para as diferentes concentrações de polieletrólito empregada no ensaio utilizando lodo da lagoa de sedimentação que não recebeu resíduo de ETA.

\begin{tabular}{|c|c|c|c|c|c|c|c|c|c|}
\hline \multirow{2}{*}{$\begin{array}{l}\text { Concentração de } \\
\text { polieletrólito } \\
\text { (g poli/kg SST) }\end{array}$} & \multicolumn{9}{|c|}{ Tempo (min) } \\
\hline & 2,5 & 5,0 & 7,5 & 10,0 & 15,0 & 20,0 & 30,0 & 45,0 & 60,0 \\
\hline 0,0 & 86,5 & 91,4 & 92,9 & 94,1 & 97,0 & 98,5 & 101,6 & 103,2 & 106,7 \\
\hline 1,0 & 84,2 & 91,4 & 94,1 & 97,0 & 98,5 & 100,0 & 103,2 & 104,9 & 106,7 \\
\hline 1,5 & 94,1 & 91,4 & 103,2 & 106,7 & 106,7 & 110,3 & 116,4 & 118,5 & 118,5 \\
\hline 2,0 & 97,0 & 97,0 & 108,5 & 110,3 & 110,3 & 114,3 & 118,5 & 120,8 & 123,1 \\
\hline 2,5 & 103,2 & 106,7 & 108,5 & 110,3 & 112,3 & 114,3 & 118,5 & 120,8 & 123,1 \\
\hline 3,0 & 103,2 & 106,7 & 110,3 & 114,3 & 114,3 & 114,3 & 118,5 & 120,8 & 123,1 \\
\hline 3,5 & 110,3 & 106,7 & 114,3 & 114,3 & 118,5 & 118,5 & 128,0 & 128,0 & 128,0 \\
\hline 4,0 & 103,2 & 110,3 & 110,3 & 110,3 & 110,3 & 114,3 & 118,5 & 118,5 & 118,5 \\
\hline
\end{tabular}




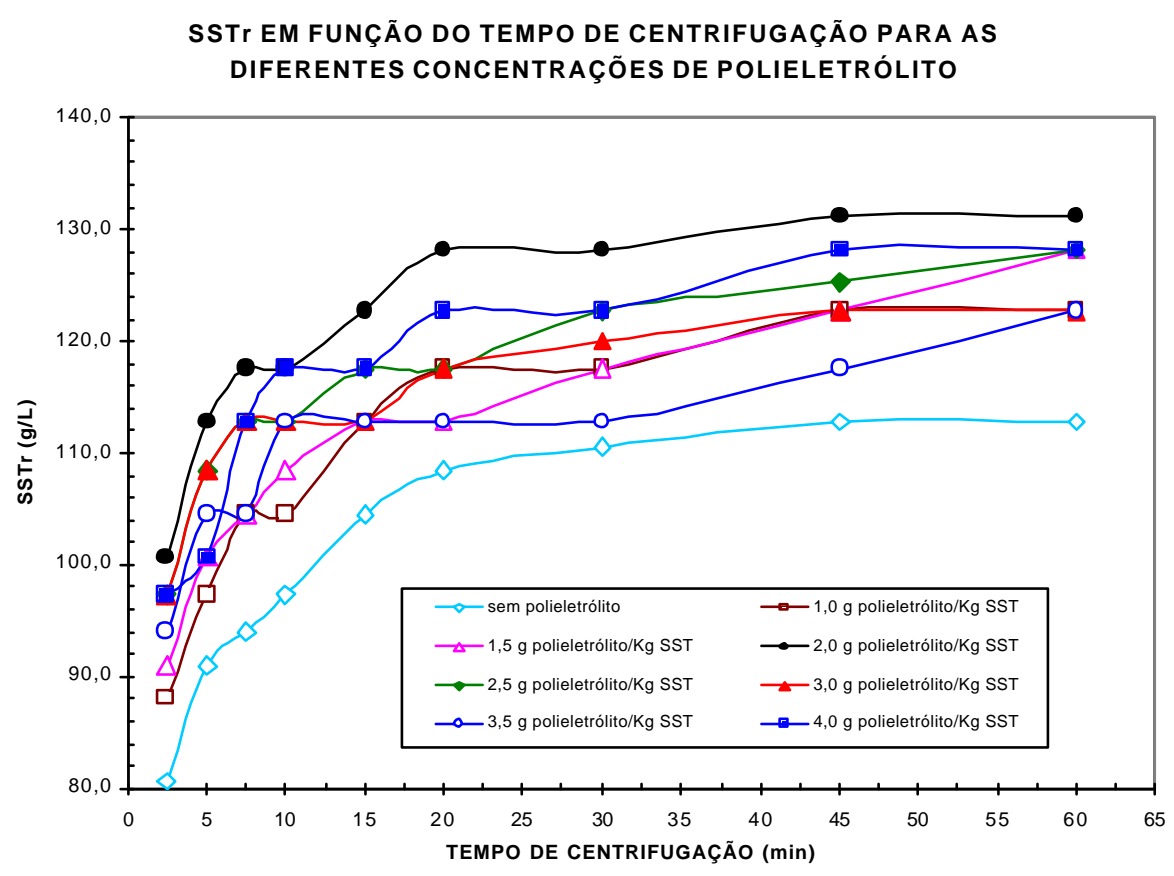

Figura 5.38 - Teores de SST em função do tempo de centrifugação para as diferentes concentrações de polieletrólito empregadas no lodo proveniente da lagoa de sedimentação que recebeu resíduo de ETA.

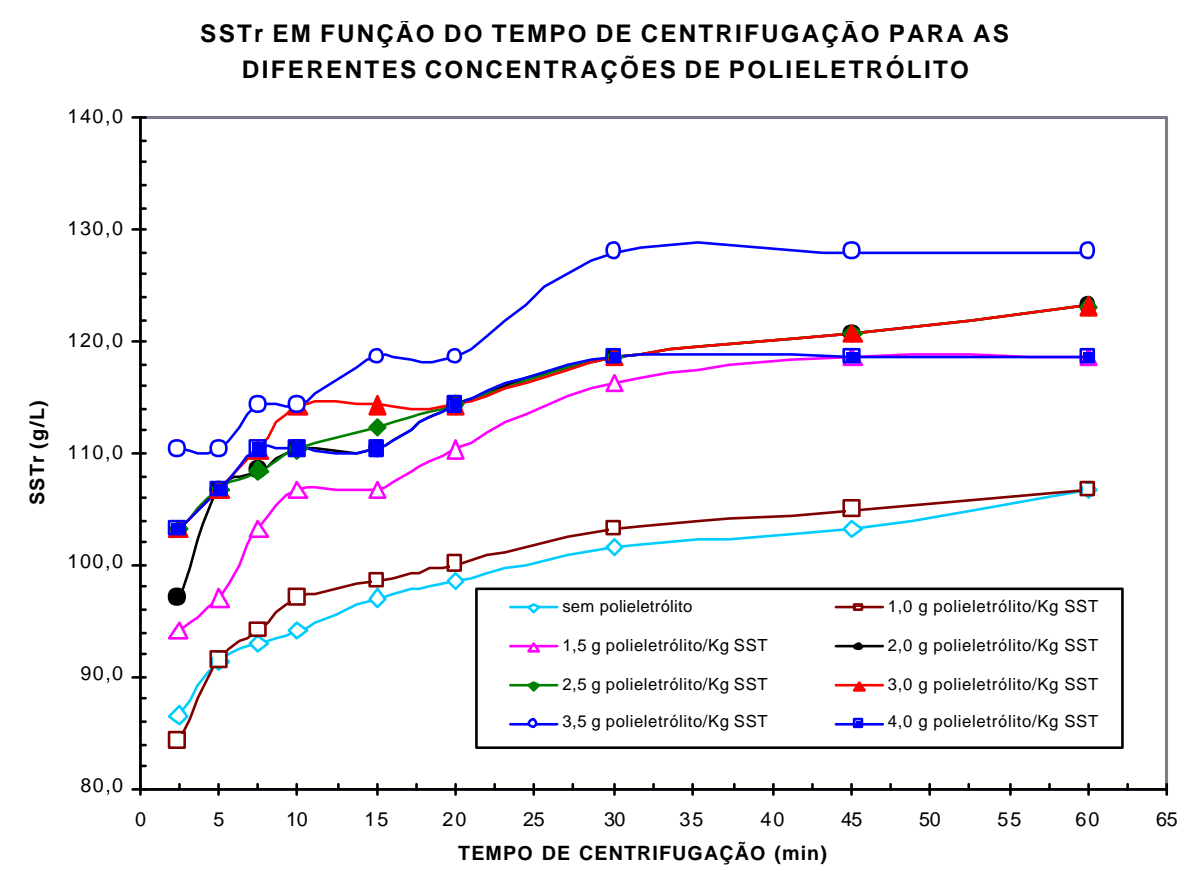

Figura 5.39 - Teores de SST em função do tempo de centrifugação para as diferentes concentrações de polieletrólito empregadas no lodo proveniente da lagoa de sedimentação que não recebeu resíduo de ETA. 


\subsection{Caracterização do Sobrenadante}

Após ensaio de centrifugação, os sobrenadantes foram coletados e caracterizados quanto a turbidez, cor e DQO, os resultados encontram-se na tabela 5.41 .

Nota-se, na tabela 5.41, que os parâmetros pesquisados foram menores para os sobrenadantes dos centrifugados provenientes da lagoa de sedimentação que recebeu resíduo da ETA-Fonte, apresentando uma melhor qualidade. Os sobrenadantes dos centrifugados sem a adição de polieletrólito apresentaram uma qualidade inferior que os demais, sendo que o sobrenadante do centrifugado do lodo da lagoa de sedimentação que não recebeu resíduo da ETA-Fonte foi o de pior qualidade. Isto indica que o coagulante, cloreto férrico, presente no resíduo da ETA, auxiliou na desidratação.

Tabela 5.41 - Caracterização dos sobrenadantes obtidos dos melhores resultados no ensaio de centrifugação.

\begin{tabular}{cccccccccccc}
\hline & \multicolumn{10}{c}{ Sobrenadantes do centrifugado } \\
\cline { 2 - 11 } PARÂMETROS & $\begin{array}{c}\text { Sobrenadante do centrifugado do } \\
\text { lodo proveniente da lagoa de } \\
\text { sedimentação que recebeu resíduo } \\
\text { da ETA-Fonte }\end{array}$ & $\begin{array}{c}\text { Sobrenadante do centrifugado do } \\
\text { lodo proveniente da lagoa de } \\
\text { sedimentação que não recebeu } \\
\text { resíduo da ETA-Fonte }\end{array}$ \\
\hline g poli/kg SST & 0,0 & 1,0 & 1,5 & 2,0 & 2,5 & 0,0 & 2,0 & 3,0 & 3,5 & 4,0 \\
\hline Turbidez (UT) & 64 & 36 & 22 & 21 & 27 & 124 & 72 & 60 & 51 & 60 \\
Cor (uC) & 332 & 202 & 130 & 110 & 164 & 688 & 352 & 270 & 152 & 280 \\
DQO (mg/L) & 233,7 & 292,3 & 269,4 & 186,7 & 248,3 & 400,6 & 397,7 & 420,6 & 224,9 & 261,1 \\
\hline
\end{tabular}

\subsection{Caracterização da Torta de Lodo}

Na tabela 5.42 estão contidos os teores dos metais presentes nas tortas de lodo dos melhores resultados dos ensaios de centrifugação.

Observa-se, na tabela 5.42, que as tortas de lodos obtidas nos ensaios de centrifugação apresentaram teores de $\mathrm{Zn}, \mathrm{Pb}, \mathrm{Cd}, \mathrm{Cu}$ e Co bem próximos. O teor de Fe e Mn na torta 1 foi superior a $100 \%$ do teor da torta 2, ao contrário do $\mathrm{Cr}$ e $\mathrm{Ni}$ que foram, aproximadamente, 50\% menores na lagoa 1. 
Tabela 5.42 - Caracterização das tortas de lodo obtidas dos melhores resultados no ensaio de centrifugação.

\begin{tabular}{ccc}
\hline \multirow{2}{*}{ PARÂMETRO } & \multicolumn{2}{c}{ Melhores resultados na centrifugação } \\
\cline { 2 - 3 } & Lodo 1 - 2,0 g poli/kg SST & Lodo 2 $\mathbf{3 , 5}$ g poli/kg SST \\
\hline $\mathrm{Mn}$ (g Mn/kg ST) & 0,726 & 0,348 \\
$\mathrm{Fe}(\mathrm{g} \mathrm{Fe} / \mathrm{kg} \mathrm{ST})$ & 81,817 & 37,058 \\
$\mathrm{Ni}$ (g Ni/kg ST) & 0,183 & 0,422 \\
$\mathrm{Zn} \mathrm{(g} \mathrm{Zn/kg} \mathrm{ST)}$ & 1,184 & 1,263 \\
$\mathrm{~Pb}$ (g Pb/kg ST) & 0,099 & 0,124 \\
$\mathrm{Cd}$ (g Cd/kg ST) & 0,003 & 0,004 \\
$\mathrm{Cu}$ (g Cu/kg ST) & 0,246 & 0,340 \\
$\mathrm{Cr}$ (g Cr/kg ST) & 0,660 & 1,382 \\
$\mathrm{Co}$ (g Co/kg ST) & 0,024 & 0,023 \\
\hline
\end{tabular}

\subsection{Ensaios de Lixiviação e Solubilização do lodo adensado}

\section{Ensaios de lixiviação}

Os resultados dos poluentes pesquisados nos extratos encontram-se nas tabelas 5.45 e 5.46, juntamente com seus limites máximos permitidos.

$\mathrm{Na}$ tabela 5.43 encontram-se as informações complementares do ensaio de lixiviação, que devido a quantidade de amostra foi realizado utilizando $50 \mathrm{~g}$ de amostra acrescentando $800 \mathrm{~mL}$ de água destilada. Os resultados, contidos nas tabelas 5.45 e 5.46, indicam que todos os parâmetros estão dentro dos limites.

Tabela 5.43 - Informações obtidas durante os ensaios de lixiviação.

\begin{tabular}{|c|c|c|}
\hline \multirow{2}{*}{ Informações } & \multicolumn{2}{|c|}{ Amostra } \\
\hline & Torta 1 & Torta 2 \\
\hline Teor de sólidos suspensos (\%) & 12,82 & 12,80 \\
\hline $\mathrm{pH}$ inicial & 7,0 & 6,85 \\
\hline $\mathrm{pH}$ final & 5,10 & 5,20 \\
\hline Quantidade de ácido acético 0,5N utilizada $(\mathrm{mL})$ & 12,60 & 9,00 \\
\hline Tempo total de lixiviação (horas) & 24 & 24 \\
\hline Volume de lixiviado obtido $(\mathrm{mL})$ & 975 & 965 \\
\hline
\end{tabular}




\section{Ensaio de solubilização}

Os resultados dos poluentes pesquisados nos extratos encontram-se nas Tabelas 5.45 e 5.46, juntamente com seus limites máximos permitidos.

Na tabela 5.44 encontram-se as informações complementares do ensaio de lixiviação, que devido a quantidade de amostra foi realizado utilizando $20 \mathrm{~g}$ de amostra (base seca) acrescentando $80,0 \mathrm{~mL}$ de água destilada.

Observa-se, nas tabelas 5.45 e 5.46, que os parâmetros Chumbo, Cromo total, Mercúrio e Ferro estavam além dos limites nos dois extratos e, apenas o $\mathrm{Mn}$ apresentou concentração superior ao limite no solubilizado da torta de lodo que recebeu resíduo da ETA-Fonte. Os demais parâmetros pesquisados estavam dentro dos limites.

Tabela 5.44 - Informações obtidas durante os ensaios de solubilização.

\begin{tabular}{lcc}
\hline \multirow{2}{*}{ Informações } & \multicolumn{2}{c}{ Amostra } \\
\cline { 2 - 3 } & Torta 1 & Torta 2 \\
\hline pH inicial & 7,0 & 6,85 \\
Tempo total de solubilização (dias) & 7 & 7 \\
Volume de solubilizado obtido $(\mathrm{mL})$ & 50,0 & 45,0 \\
\hline
\end{tabular}

Obs.: torta 1 - obtido do ensaio de centrifugação utilizando lodo da lagoa de sedimentação proveniente da ETE-piloto que recebeu resíduo da ETA-Fonte.

torta 2 - obtido do ensaio de centrifugação utilizando lodo da lagoa de sedimentação proveniente da ETE-piloto que não recebeu resíduo da ETA-Fonte. 
Tabela 5.45 - Resultados dos poluentes pesquisados nos extratos do lixiviado e do solubilizado da torta obtida no ensaio de centrifugação com o lodo da lagoa de sedimentação proveniente da ETE-piloto que recebeu resíduo da ETA-Fonte, juntamente com seus limites máximos permitidos, de acordo com a NBR 10004/1987 Anexo G Listagem rf 7 - Concentração - limite máximo no extrato obtido no teste de lixiviação e NBR 10004/1987 Anexo H Listagem no 8 - Padrões para o teste de solubilização.

\begin{tabular}{|c|c|c|c|c|}
\hline \multirow[b]{2}{*}{ Poluente } & \multicolumn{2}{|c|}{ Lixiviação } & \multicolumn{2}{|c|}{ Solubilização } \\
\hline & $\begin{array}{l}\text { Limite máximo } \\
\text { no extrato (mg/L) }\end{array}$ & $\begin{array}{l}\text { Resultados } \\
(\mathrm{mg} / \mathrm{L})\end{array}$ & $\begin{array}{l}\text { Limite máximo } \\
\text { no extrato (mg/L) }\end{array}$ & $\begin{array}{l}\text { Resultados } \\
\text { (mg/L) }\end{array}$ \\
\hline Arsênio & 5,0 & $<0,0001$ & 0,05 & $<0,0001$ \\
\hline Bário & 100,0 & $<0,05$ & 1,0 & $<0,05$ \\
\hline Cádmio & 0,05 & 0,032 & 0,005 & $<0,05$ \\
\hline Chumbo & 5,0 & 0,127 & 0,05 & 0,496 \\
\hline Cianeto & - & - & 0,1 & $<0,001$ \\
\hline Fenol & - & - & 0,001 & NR \\
\hline Nitrato & - & - & 10,0 & 8,28 \\
\hline Cromo Total & 5,0 & 0,032 & 0,05 & 0,184 \\
\hline Fluoreto & 150,0 & 0,25 & 1,5 & 0,32 \\
\hline Mercúrio & 0,1 & 0,019 & 0,001 & 0,052 \\
\hline Prata & 5,0 & $<0,05$ & 0,05 & $<0,05$ \\
\hline Selênio & 1,0 & $<0,05$ & 0,01 & $<0,05$ \\
\hline Aldrin & 0,003 & 0,00001 & $3,0 \times 10^{-5}$ & ND \\
\hline DDT & 0,1 & ND & $1,0 \times 10^{-4}$ & ND \\
\hline Dieldrin & 0,003 & ND & $3,0 \times 10^{-4}$ & ND \\
\hline Endrin & 0,02 & ND & $2,0 \times 10^{-4}$ & ND \\
\hline Epóxi-heptacloro & 0,01 & ND & $1,0 \times 10^{-4}$ & ND \\
\hline Heptacloro & 0,01 & ND & $1,0 \times 10^{-4}$ & ND \\
\hline Hexaclorobenzeno & 0,001 & ND & $1,0 \times 10^{-4}$ & ND \\
\hline Lindano & 0,3 & ND & $3,0 \times 10^{-4}$ & ND \\
\hline Pentaclorofenol & 1,0 & 0,00002 & 0,01 & ND \\
\hline Alumínio & - & - & 0,2 & 0,008 \\
\hline Cloreto & - & - & 250,0 & 96,0 \\
\hline Cobre & - & - & 1,0 & 0,112 \\
\hline Dureza & - & - & 500,0 & 320,0 \\
\hline Ferro & - & - & 0,3 & 4,812 \\
\hline Manganês & - & - & 0,1 & 0,768 \\
\hline Sódio & - & - & 200,0 & 200,0 \\
\hline Surfactantes & - & - & 0,2 & $N R$ \\
\hline Sulfato & - & - & 400,0 & 120,0 \\
\hline Zinco & - & - & 5,0 & 0,54 \\
\hline
\end{tabular}

ND - Não detectado; NR - Não realizado; - não necessário 
Tabela 5.46 - Resultados dos poluentes pesquisados nos extratos do lixiviado e do solubilizado da torta obtida no ensaio de centrifugação com o lodo da lagoa de sedimentação proveniente da ETE-piloto que não recebeu resíduo da ETAFonte, juntamente com seus limites máximos permitidos, de acordo com a NBR 10004/1987 Anexo G Listagem rf 7 - Concentração - limite máximo no extrato obtido no teste de lixiviação e NBR 10004/1987 Anexo H Listagem no 8 - Padrões para o teste de solubilização.

\begin{tabular}{|c|c|c|c|c|}
\hline \multirow[b]{2}{*}{ Poluente } & \multicolumn{2}{|c|}{ Lixiviação } & \multicolumn{2}{|c|}{ Solubilização } \\
\hline & $\begin{array}{l}\text { Limite máximo } \\
\text { no extrato }(\mathrm{mg} / \mathrm{L})\end{array}$ & $\begin{array}{c}\text { Resultados } \\
(\mathrm{mg} / \mathrm{L})\end{array}$ & $\begin{array}{l}\text { Limite máximo } \\
\text { no extrato (mg/L) }\end{array}$ & $\begin{array}{l}\text { Resultados } \\
(\mathrm{mg} / \mathrm{L})\end{array}$ \\
\hline Arsênio & 5,0 & $<0,0001$ & 0,05 & $<0,0001$ \\
\hline Bário & 100,0 & $<0,05$ & 1,0 & $<0,05$ \\
\hline Cádmio & 0,05 & 0,032 & 0,005 & $<0,05$ \\
\hline Chumbo & 5,0 & 0,136 & 0,05 & 0,476 \\
\hline Cianeto & - & - & 0,1 & $<0,001$ \\
\hline Fenol & - & - & 0,001 & NR \\
\hline Nitrato & - & - & 10,0 & 5,25 \\
\hline Cromo Total & 5,0 & 0,051 & 0,05 & 0,188 \\
\hline Fluoreto & 150,0 & 1,34 & 1,5 & $<0,1$ \\
\hline Mercúrio & 0,1 & 0,020 & 0,001 & 0,0224 \\
\hline Prata & 5,0 & $<0,05$ & 0,05 & $<0,05$ \\
\hline Selênio & 1,0 & $<0,05$ & 0,01 & $<0,05$ \\
\hline Aldrin & 0,003 & ND & $3,0 \times 10^{-5}$ & ND \\
\hline DDT & 0,1 & ND & $1,0 \times 10^{-4}$ & ND \\
\hline Dieldrin & 0,003 & ND & $3,0 \times 10^{-4}$ & ND \\
\hline Endrin & 0,02 & ND & $2,0 \times 10^{-4}$ & ND \\
\hline Epóxi-heptacloro & 0,01 & ND & $1,0 \times 10^{-4}$ & ND \\
\hline Heptacloro & 0,01 & ND & $1,0 \times 10^{-4}$ & ND \\
\hline Hexaclorobenzeno & 0,001 & ND & $1,0 \times 10^{-4}$ & ND \\
\hline Lindano & 0,3 & ND & $3,0 \times 10^{-4}$ & ND \\
\hline Pentaclorofenol & 1,0 & 0,000005 & 0,01 & ND \\
\hline Alumínio & - & - & 0,2 & 0,032 \\
\hline Cloreto & - & - & 250,0 & 76,0 \\
\hline Cobre & - & - & 1,0 & 0,116 \\
\hline Dureza & - & - & 500,0 & 280,0 \\
\hline Ferro & - & - & 0,3 & 4,712 \\
\hline Manganês & - & - & 0,1 & 0,10 \\
\hline Sódio & - & - & 200,0 & 180,0 \\
\hline Surfactantes & - & - & 0,2 & NR \\
\hline Sulfato & - & - & 400,0 & 140,0 \\
\hline Zinco & - & - & 5,0 & 4,98 \\
\hline
\end{tabular}

ND - Não detectado; NR - Não realizado; - não necessário. 


\section{CONCLUSÕES E RECOMENDAÇÕES}

\subsection{CONCLUSÕES REFERENTES À PRIMEIRA FASE DE ESTUDO}

Os ensaios de sedimentação realizados na primeira fase permitiram concluir que:

- A coluna que recebeu maior quantidade de resíduo da ETA-SC apresentou um sobrenadante com menor teor de SST, sendo que após 120 minutos de sedimentação a diferença com a coluna de sedimentação que recebeu apenas esgoto sanitário foi da ordem de $35 \mathrm{mg} / \mathrm{L}$ na média dos três pontos de coletas;

- Após 120 minutos de sedimentação ocorreu uma maior redução na concentração dos parâmetros cor, turbidez, SST, SSV e DQO, além de coliformes totais, Escherichia coli, ovos de Ancylostomidae e larvas de Strongyloides sp nos sobrenadantes provenientes das colunas de sedimentação que receberam resíduo da ETASC.

- Os sedimentos obtidos nos ensaios de sedimentação apresentaram maior quantidade de ST com menor resistência específica à filtração nas colunas de sedimentação que receberam resíduo da ETA-SC, podendo-se concluir que em uma possível desidratação mecânica estes materiais seriam mais fáceis de desidratar.

- Nos ensaios de toxicidade anaeróbia através do teste da atividade metanogênica, a medida que se aumentou o resíduo da ETA-SC no sistema a concentração molar de metano foi reduzida. Mesmo na menor concentração estudada, de 28,28 mg SST/L de esgoto sanitário, houve redução da ordem de $18 \%$ na produção de metano. Portanto, o resíduo da ETA-SC teve influência negativa sobre os microrganismos metanogênicos, sendo que nas primeiras 
180 horas deste ensaio a produção de metano foi praticamente a mesma em todos frascos-reator;

- No exame microscópico realizado no licor misto dos frasco-reator do ensaio da atividade metanogênica ficou evidenciado que algumas espécies de microrganismos tais como do gênero Methanothrix $s p$ foram inibidas pela presença do resíduo da ETA-SC, sendo que foram encontradas em maior número no frasco-reator controle e em menor quantidade à medida que se aumentou a adição do resíduo da ETA-SC. Este resíduo favoreceu o crescimento dos bacilos fluorescentes, sendo progressivo no sentido do frascoreator com menor quantidade de resíduo da ETA-SC para o de maior quantidade.

- Provavelmente, não ocorrerá deterioração no efluente dos decantadores primários de uma ETE, já que a qualidade do sobrenadante nas colunas de sedimentação não foi deteriorada com a presença de resíduo da ETA-SC e, que ocorrerá interferências no desempenho dos processos biológicos uma vez que ocorreu redução na produção metano no ensaio de atividade metanogênica.

\subsection{CONCLUSÕES REFERENTES À SEGUNDA FASE DE ESTUDO}

O ensaio realizado adicionando resíduo da ETA-Fonte, que utiliza cloreto férrico como coagulante primário, na ETE-piloto, na proporção de 49,92 g de SST/L esgoto sanitário, durante um período de 90 dias, permitiu concluir que:

- O efluente final produzido pela ETE-piloto que recebeu resíduo da ETAFonte mostrou-se com melhor qualidade.

- No exame microscópico não foram constatadas influências negativas no licor misto da lagoa de aeração que recebeu resíduo da ETAFonte. Neste material não foram encontradas bactérias filamentosas, sendo que, no licor misto da lagoa de aeração que não recebeu resíduo da ETA-Fonte foram encontradas tais bactérias. Portanto, provavelmente o resíduo da ETA-Fonte inibiu o aparecimento de bactérias filamentosas.

- A quantidade de sólidos sedimentáveis presentes na lagoa de aeração que recebeu resíduo da ETA-Fonte foi, na média, 5,3\% maior que na lagoa que não recebeu tal resíduo. 
- A resistência específica apresentada pelo lodo gerado do sistema que recebeu resíduo da ETAFonte foi menor que no sistema que não o recebeu, sendo de $1,42 \times 10^{13} / \mathrm{kg} \mathrm{e} 4,44 \times 10^{13}$, respectivamente.

- A desidratação do lodo por centrifugação necessitou de menor quantidade de polieletrólito por $\mathrm{kg}$ de SST, para o lodo da lagoa de sedimentação proveniente da ETE-piloto que recebeu resíduo da ETA-Fonte. A concentração de metais Fe e Mn na torta do lodo da ETE-Piloto que recebeu resíduo da ETAFonte foi praticamente o dobro do lodo da ETE-Piloto que não recebeu resíduo da ETA-Fonte.

- O teor de ST presente no resíduo da ETA-Fonte, composto por descarga de decantador e lavagem de filtros, para este estudo foi da ordem de $1158 \mathrm{mg} / \mathrm{L}$ na sua totalidade de SF, $878 \mathrm{mg} / \mathrm{L}$, e, provavelmente, não causarão problemas de deposição, pois de acordo com TSUTIYA E HIRATA (2001), de maneira geral, problemas de deposição não são observados com velocidade mínima de 0,8 $\mathrm{m} / \mathrm{s}$ ou concentração de sólidos menor que $3 \%$.

- Com relação aos ensaios de lixiviação, nenhum parâmetro foi encontrado fora do limite máximo permitido, ao contrário do extrato do solubilizado onde o Chumbo, Cromo total, Mercúrio e Ferro estavam além dos limites nos dois extratos. A presença de $\mathrm{Mn}$ foi verificada apenas no solubilizado da torta de lodo que recebeu resíduo da ETA-Fonte. Portanto, sem levar em consideração o Mn, os demais parâmetros pesquisados não foram influenciados pelo resíduo da ETA-Fonte adicionado à ETE-Piloto.

\subsection{RECOMENDAÇÕES}

O autor recomenda que:

- Caso houver interesse em fazer a disposição do resíduo de ETA em ETE, seja qual for o tipo de coagulante empregado na ETA ou a tecnologia de tratamento empregada na ETE, que sejam realizados estudos verificando a viabilidade ou não desta alternativa para cada caso;

- Antes de lançar o resíduo de ETA na rede de esgoto, seja feito uma equalização para minimizar os problemas que poderão advir; 
- Sejam realizados novos estudos verificando os efeitos produzidos em uma ETE, composta por lagoas aeradas e de sedimentação, quando lançados resíduos de uma ETA que utiliza sulfato de alumínio como coagulante primário;

- Outros estudos com adição de resíduo de ETA sejam realizados, empregando outros processos de tratamento de esgotos, como por exemplo, lodos ativados e lagoas anaeróbias.

- Sejam promovidos estudos para dispor o lodo gerado, pelo sistema que recebeu resíduo de ETA, na agricultura, verificando as vantagens ou desvantagens. 


\section{REFEFERÊNCIAS BIBLIOGRÁFICAS}

ALEM SOBRINHO, P. (2000). Tratamento de esgoto e geração de lodo. In: Impacto ambiental do uso agrícola do lodo de esgoto.EMBRAPA Meio Abiente. Jaguariúna/SP. P. 11-24.

ALMEIDA, N. A, GONÇALVES, M. C., GUIMARÃES, S. A. Z. (1991a). Utilização do teste de resistência específica na operação de filtros prensa. Revista DAE, v. 51, n. 160 , p. 20-26, jan/jun.

ALMEIDA, N. A, GONÇALVES, M. C., GUIMARÃES, S. A. Z. (1991b). Desidratação de lodos ativados utilizando sulfato ferroso como condicionante químico. Revista $D A E$, v. 51 , n. 161 , p. 8-12, set/dez

AMERICAN PUBLIC HEALTH ASSOCIATION; AMERICAN WATER WORKS ASSOCIATION; WATER ENVIRONMENT FEDERATION (1998). Standard Methods for the exanmination of water and wastewater. 20. ed., Washington, D.C, USA.

AMERICAN SOCIETY OF CIVIL ENGINEERS; AMERICAN WATER WORKS ASSOCIATION (1996). Management of Water Treatment Plant Residuals. New York, AWWA.

ANDREOLI, C.V.; VON SPERLING, M.; FERNANDES, F. (2001a). Lodo de esgotos: tratamento e disposição final. 1 ed, Belo Horizonte: Departamento de Engenharia Sanitária e Ambiental; Universidade Federal de Minas Gerais; Companhia de Saneamento do Paraná, 2001. 484p.

ANDREOLI, C.V.; HOPPEN, C.; NETTO, O.S.M. (2001). Desidratação do lodo aeróbio e séptico através do uso de centrifuga tipo decanter, com e sem o uso de polieletrólitos. In: CONGRESSO BRASILEIRO DE ENGENHARIA SANITÁRIA E AMBIENTAL, 21., João Pessoa - PB. Anais eletrônicos III-028, 7p. Rio de Janeiro, ABES. 
ASSOCIAÇÃO BRASILEIRA DE NORMAS TÉCNICAS (1987) - ABNT. NBR-10004 Resíduos sólidos

ASSOCIAÇÃO BRASILEIRA DE NORMAS TÉCNICAS (1987) - ABNT. NBR-10005 lixiviação de resíduos.

ASSOCIAÇÃO BRASILEIRA DE NORMAS TÉCNICAS (1987) - ABNT. NBR-10006 Solubilização de resíduos.

ASSOCIAÇÃO BRASILEIRA DE NORMAS TÉCNICAS (1987) - ABNT. NBR-10007 Amostragem de resíduos.

AYRES, R.M.; MARA, D.D. (1996). Analysis of wastewater for use in agriculture. World Health Organization. Geneva, 1996.

BARBOSA, A.B.D. (1997). A experiência da CAESB em recuperação de água de lavagem de filtros e desidratação de lodo de ETA. In: CONGRESSO BRASILEIRO DE ENGENHARIA SANITÁRIA E AMBIENTAL, 19., Foz do Iguaçu, 1997. Anais eletrônicos II-070. Rio de Janeiro, ABES. p. 1501-1508.

CALKINS, J.R; NOVAK, T.J. (1974). Characterization of chemical sludges. Processing Water-Treatment-Plant Sludge. American Water Works Association, Denver, Colorado, USA, 512p.

CARVALHO, E.H.; DI BERNARDO, L. (1999). Interferência dos despejos de estações de tratamento de água nas estações de tratamento de esgoto. In: CONGRESSO BRASILEIRO DE ENGENHARIA SANITÁRIA E AMBIENTAL, 20, Rio de Janeiro. Anais eletrônicos II-037. Rio de Janeiro, ABES. P. 1230-1238.

CARVALHO, E.H. (2000). Disposição dos resíduos gerados nas estações de tratamento de água em estações de tratamento de esgoto com decantação primária. São Carlos, 2000, 224p. Tese (Doutorado) - Escola de Engenharia de São Carlos, Universidade de São Paulo.

CASTRO et al. (1997a). O problema da caracterização dos efluentes gerados nas estações de tratamento de água - o caso da unidade de tratamento e recuperação de resíduos - UTR do sistema Rio das Velhas. In: CONGRESSO BRASILEIRO DE ENGENHARIA SANITÁRIA E AMBIENTAL, 19., Foz do Iguaçu, 1997. Anais eletrônicos II-059. Rio de Janeiro, ABES. p. 1423-1430.

CASTRO et al. (1997b). Soluções para tratamento de resíduos de estação de tratamento de água - proposta para a unidade de tratamento de resíduos (UTR) do Rio das Velhas na RMBH. In: CONGRESSO BRASILEIRO DE ENGENHARIA SANITÁRIA E AMBIENTAL, 19., Foz do Iguaçu, 1997. Anais eletrônicos II-057. Rio de Janeiro, ABES. p. 1399-1410. 
CETESB (1993). Coliformes Totais e Fecais - Determinação pela técnica de Tubos Múltiplos. L5. 202, jan/93.

CHRISTENSEN, G. L. (1983). Units for specific resistence. Journal WPCF, v. $55 \mathrm{n}$. 4, p. 417-419, abr.

CHRISTENSEN, G. L., DICK, R. I. (1985). Specific resistence measurements: Nonparabolic data. Journal of Environmental Engineering,v.111, n. 6, p. 243-257, jun.

CORDEIRO, J. S. (1993). O problema dos lodos gerados nos decantadores em estações de tratamento de água. São Carlos, 342p. Tese (Doutorado) - Escola de Engenharia de São Carlos, Universidade de São Paulo.

CORDEIRO, J.S.; PARSEKIAN, M.P.S. (1997). Gerenciamento de estações de tratamento de águas - lição para os anos 2000. In: CONGRESSO BRASILEIRO DE ENGENHARIA SANITÁRIA E AMBIENTAL, 19., Foz do Iguaçu, 1997. Anais eletrônicos II-034. Rio de Janeiro, ABES. p. 1237-1247.

CORNWELL, D.A. et al. (1987). Handbook of pratice water treatment plant vaste management. 1 ed., Virginia, American Water Works Association Resarch Foudation, Denver, 431p.

CORNWELL, D.A.; KOPPERS, H.M.N. (1990). Slib, schlamm, sludge. Amercan Water Works Association, Research Foudation, KIWA. Research Foudation, Denver.

CORNW ELL, D. A., LEER, R. G.. (1994). Waste stream recycling: its effect on water quality. Journal AWWA, p. 50-63, nov.

CRISPIN, W.M.C. (1994). Estudo seletivo de métodos para pesquisa de ovos de helmintos em águas residuais. In: SIMPÓSIO LUSO-BRASILEIRO DE ENGENHARIA SANITÁRIA E AMBIENTAL, 6., Florianópolis, 1994. Anais. Rio de Janeiro, ABES/APRH. v.1, p. 364-371.

DI BERNARDO, L. (1993). Métodos e técnicas de tratamento de água. Rio de Janeiro, ABES.

DI BERNARDO, L.; SCALIZE, P.S.; FRAGIACOMO, P.; TROFINO, J.C.; VIUDES, M.A.P. (1999). Clarificação da água de lavagem de filtros de sistemas de filtração direta ascendente e desaguamento do lodo por centrifugação. . In: CONGRESSO BRASILEIRO DE ENGENHARIA SANITÁRIA E AMBIENTAL, 20, Rio de Janeiro. Anais eletrônicos II-084. Rio de Janeiro, ABES. P. 1555-1565.

DI BERNARDO, L.; SCALIZE, P.S.; SOUZA FILHO, A.G. (1999a). Água de lavagem de filtros rápidos. In: REALI, M.P., coord. Noções gerais de tratamento 
e disposição final de lodos de estações de tratamento de água. Rio de Janeiro, ABES. Cap. 7, p. 143-168.

DI BERNARDO, L.; CARVALHO, E.H.; SCALIZE, P.S. (1999b). Disposição de resíduos líquidos de ETAs em ETEs. In: REALI, M.P., coord. Noções gerais de tratamento e disposição final de lodos de estações de tratamento de água. Rio de Janeiro, ABES. Cap. 8, p. 169-202.

ELLIOTT, H. A. et al. (1990). Land aplication of water treatment sludges: impact and management. AWWARF, 99p.

ESCOBAR, J.C. (2001). Tratamento e recuperação da água de lavagem dos filtros de uma estação de filtração direta e simulação da disposição dos lodos em estações de tratamento de esgoto. São Carlos, 2001. 144 p. Tese (Doutorado) Escola de Engenharia de São Carlos, Universidade de São Paulo.

FABER, H. A.; NARDOZZI,, A. D. (1972). Water treatment plant waste disposal action now. Journal AWWA,v. 64, n. 10, p. 674-680, oct.

FERREIRA FILHO, S.S. (1997). Pré-condicionamento de lodos de estações de tratamento de água visando o seu adensamento por gravidade. In: CONGRESSO BRASILEIRO DE ENGENHARIA SANITÁRIA E AMBIENTAL, 19., Foz do Iguaçu, 1997. Anais eletrônicos II-025. Rio de Janeiro, ABES. p. 11811192.

FERREIRA, C.A.; ANDREOLI, C.V.; LARA, A.I. (1999). Riscos associados ao uso do lodo de esgoto. In: ANDREOLI, C.V., coord. Uso e manejo do lodo de esgoto na agricultura. Rio de Janeiro, PROSAB, Programa de pesquisa em Saneamento Básico, 1999. Cap. 3, p. 29-33.

GONÇALVES, R.F.; LUDOVICE, M. (2000). Alternativas de minimização de produção e desaguamento do lodo de esgoto. In: Impacto ambiental do uso agrícola do lodo de esgoto.EMBRAPA Meio Ambiente. Jaguariúna/SP. P. 25-44.

GRABAREK, R. J.; KRUG, E. C. (1987). Silvicultural apllication of alum sludge. Journal AWWA, v. 9, n. 6, p. 84-88, jun.

GRANDIN, S. R. (1992). Disidratação de lodos produzidos nas estações de tratamento de água. São Paulo, 456p. Dissertação (Mestrado) - Escola Politécnica, Universidade de São Paulo.

IMHOFF, K.; IMHOFF, K.R. (1986). Manual de tratamento de águas residuárias. Trad. Por Max Lothar Hess. São Paulo, Editora Edgard Blücher Ltda.

LEME, H.H.P.; MERLI, G.L. (2001). Estação de tratamento de lodo gerado pela ETA Capim Fino. In: CONGRESSO BRASILEIRO DE ENGENHARIA 
SANITÁRIA E AMBIENTAL, 21, João Pessoa, PB. Anais eletrônicos r014, 6p. Rio de Janeiro, ABES.

METCALF \& EDDY (1977). Tratamiento y depuración de las aguas residualis. Madrid, Editorial labor, S.A.

MURRAY, K.; DILLON, G. (1994). Waterworks residuals management: $A$ comparasion of US and UK practices. In: The management of water and wasterwater solids for the $21^{\text {st }}$. Century, jun., 19-22, Washington D.C, USA.

NOVAK, J.T., CALKINS, D. C. (1975). Sludge dewatering and its physical properties. Journal AWWA, v.67, n.1, p. 42-45, jan.

PATRIZZI, L.J. (1998). Redução do volume de lodo gerado em decantadores de estações de tratamento de água (ETAs) tratadicionais, utilizando espessamento por flotação e por gravidade seguidos de centrifugação. São Carlos. 222 p. Dissertação (Mestrado) - Escola de Engenharia de São Carlos, Universidade de São Paulo.

REALI, M.A.P. (1991). Concepção e Avaliação de um sistema compacto para tratamento de águas de abastecimento, utilizando o processo de flotação por ar dissolvido e filtração com taxa declinante. São Carlos. 2v. Tese (Doutorado) Escola de Engenharia de São Carlos, Universidade de São Paulo.

SARON, A.; SILVA, E.P. (1997). Redução na dosagem de sulfato de alumínio na ETA Guaraú com a utilização do sistema de recuperação de água de lavagem de filtros. In: CONGRESSO BRASILEIRO DE ENGENHARIA SANITÁRIA E AMBIENTAL, 19., Foz do Iguaçu, 1997. Anais eletrônicos II-011. Rio de Janeiro, ABES. p. 1088-1095.

SCALIZE, P.S. (1997). Caracterização e clarificação por sedimentação da água de lavagem de filtros rápidos de estações de tratamento de água que utilizam sulfato de alumínio como coagulante primário. São Carlos. 1997, 220 p. Dissertação (Mestrado) - Escola de Engenharia de São Carlos, Universidade de São Paulo.

SCALIZE, P.S.; DIBERNARDO, L. (2000). Caracterização da água de lavagem de filtros rápidos de estações de tratamento de água e dos sobrenadantes e sedimentos obtidos após ensaio de clarificação utilizando polímero aniônico. In: XXVII CONGRESSO INTERAMERICANO DE INGENIERIA SANITÁRIA Y AMBIENTAL, Porto Alegre - RS - Brasil, 2000. Anais eletrônicos II-023, 11p. Rio de Janeiro, ABES. 
SCHUKER, P. F. et al. (1991). Slow sand and diatomaceus earth filtration of cysts and other particulates. Water Research, v. 25, n. 8, p. 995-1005, Aug.

SEREC - Serviços de Engenharia Consultiva Ltda. Estudo de concepção para a recuperação das águas de lavagens, tratamento e disposição de resíduos das ETA's da RMSP. V.1-3, abril, 1987. (Estudo Técnico SEREC/SABESP), 1987.

SOUSA, J.T. (1996). Pós-tratamento de efluentes de reator anaeróbio de fluxo ascendente em reator aeróbio sequencial em batelada e coluna de lodo anaeróbio para desnitrificação. São Carlos: 1996, 258p. Tese (Doutorado) Escola de Engenharia de São Carlos, Universidade de São Paulo.

SOUZA FILHO, A.G. (1998). Caracterização e clarificação por sedimentação da água de lavagem de filtros rápidos de uma ETA que utiliza cloreto férrico como coagulante primário. São Carlos: 1998, 245 p. Dissertação (Mestrado) - Escola de Engenharia de São Carlos, Universidade de São Paulo.

SPEECE, R.E. (1996). Anaerobic Biotechnology for Industrial Wastewaters, Archae Press, 393p., Estados Unidos.

TSUTIYA, M.T.; HIRATA, A.Y. (2001). Aproveitamento e disposição final de lodos de estações de tratamento de água do estado de São Paulo. In: CONGRESSO BRASILEIRO DE ENGENHARIA SANITÁRIA E AMBIENTAL, 21., João Pessoa PB. Anais eletrônicos 1-025, 9p. Rio de Janeiro, ABES.

TSUTIYA, M.T. et al (2002). Biossólidos na Agricultura. 2 ed., São Paulo: ABES/SP, 2002. 468p.

VAN HAANDEL, A. ; GERRIT, M. (1999). O comportamento do sistema de lodo ativado - Teoria e Aplicações para Projetos e Operações, Efgraf, 472p., Campina Grande, PB.

VON SPERLING, M. (1997). Princípios do tratamento biológico de águas residuárias. In: "Lodos Ativados", Departamento de Engenharia Sanitária e Ambiental; Universidade Federal de Minas Gerais, v.4, 415 p., Belo Horizonte, MG. 